\title{
Evaluation of phytotoxicity testing: Assessing the effects of herbicides on non-target plants using microcosm tests
}

\author{
Rebecca L. Dalton, H.B.Sc.
}

A thesis submitted to the Faculty of Graduate Studies and Research in partial fulfillment of the requirement for the degree of

\author{
Master of Science \\ Biology \\ Specialization in Chemical and Environmental Toxicology
}

Department of Biology

Faculty of Science

Carleton University

Ottawa, Ontario

(C) Rebecca L. Dalton, 2007 


$\begin{array}{ll}\begin{array}{l}\text { Library and } \\ \text { Archives Canada }\end{array} & \begin{array}{l}\text { Bibliothèque et } \\ \text { Archives Canada }\end{array} \\ \begin{array}{l}\text { Published Heritage } \\ \text { Branch }\end{array} & \begin{array}{l}\text { Direction du } \\ \text { Patrimoine de l'édition }\end{array} \\ \begin{array}{l}\text { 395 Wellington Street } \\ \text { Ottawa ON K1A ON4 }\end{array} & \begin{array}{l}\text { 395, rue Wellington } \\ \text { Ottawa ON K1A ON4 } \\ \text { Canada }\end{array}\end{array}$

Your file Votre référence ISBN: 978-0-494-27016-5 Our file Notre référence ISBN: 978-0-494-27016-5

NOTICE:

The author has granted a nonexclusive license allowing Library and Archives Canada to reproduce, publish, archive, preserve, conserve, communicate to the public by telecommunication or on the Internet, loan, distribute and sell theses worldwide, for commercial or noncommercial purposes, in microform, paper, electronic and/or any other formats.

The author retains copyright ownership and moral rights in this thesis. Neither the thesis nor substantial extracts from it may be printed or otherwise reproduced without the author's permission.
AVIS:

L'auteur a accordé une licence non exclusive permettant à la Bibliothèque et Archives Canada de reproduire, publier, archiver, sauvegarder, conserver, transmettre au public par télécommunication ou par l'Internet, prêter, distribuer et vendre des thèses partout dans le monde, à des fins commerciales ou autres, sur support microforme, papier, électronique et/ou autres formats.

L'auteur conserve la propriété du droit d'auteur et des droits moraux qui protège cette thèse. $\mathrm{Ni}$ la thèse ni des extraits substantiels de celle-ci ne doivent être imprimés ou autrement reproduits sans son autorisation.
In compliance with the Canadian

Privacy Act some supporting forms may have been removed from this thesis.

While these forms may be included in the document page count, their removal does not represent any loss of content from the thesis.
Conformément à la loi canadienne sur la protection de la vie privée, quelques formulaires secondaires ont été enlevés de cette thèse.

Bien que ces formulaires aient inclus dans la pagination, il n'y aura aucun contenu manquant.

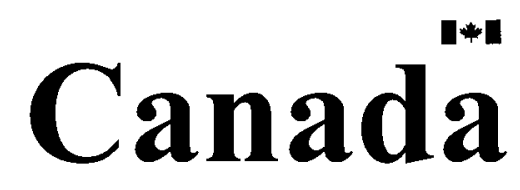




\begin{abstract}
Intensification of agriculture and the corresponding increase in herbicide use has led to concern regarding the effects these chemicals may have on non-target plants of agroecosystems. Current pesticide registration guidelines are focused on testing crop species grown singly in pots under greenhouse conditions and may not provide adequate measures of protection to non-crop species. The main objective of this study was to compare the response of terrestrial and wetland plants to glyphosate and atrazine when grown singly in pots versus under different microcosm conditions. Greenhouse microcosms were generally more sensitive than single species tests. Plants grown for an extended test period or in semi-natural field conditions were generally less sensitive. Sensitivity was found to be dependent on interactions between species and test conditions. Stomatal conductance and the chlorophyll fluorescence parameter, Fv/Fm were found to be effective non-destructive indicators of herbicidal damage and may provide useful additional information in phytotoxicity testing.
\end{abstract}




\section{ACKNOWLEDGEMENTS}

First and foremost, I would like to thank my supervisor Céline Boutin. Céline, thank you for your patience, enthusiasm, and remarkable ability to balance providing guidance while encouraging independent thought. Thank you also for having enough confidence in me to keep me around for another four years. I look forward to many more fabulous dinner parties!

I would also like to thank my co-supervisor Andrew Simons and committee members Frances Pick and Pierre Mineau for their many helpful comments and suggestions. You were all an integral part in developing this project and keeping it on track.

I am also grateful to the Pesticide Science Fund for providing financial support for this project as well to the National Wildlife Research Centre and Carleton University for providing research facilities and financial support. Chemical analysis was provided by S. Trudeau, F. Maisonneuve and C. Corrigan at NWRC.

Thank you to my office mates, friends and family for providing support as well as much needed distractions and entertainment. I would especially like to thank my parents. Thank you for instilling a love for learning, for always believing in me and for encouraging me to pursue my goals.

Last but not least, I would like to thank my fiancé for his unwavering support and encouragement. Elias, you now know more about plants than any economist should. Your good humoured assistance with moving and photographing countless plants, putting out biological control and removing dead mice, all the while keeping everything running smoothly at home, was very much appreciated. I couldn't have done it without you! 


\section{TABLE OF CONTENTS}

Abstract. .ii

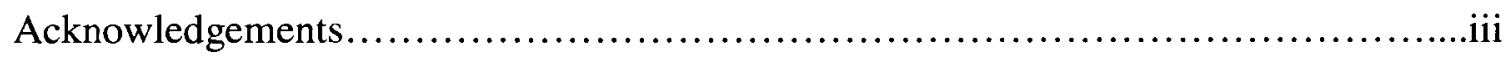

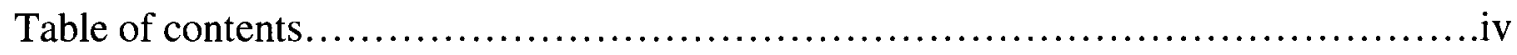

List of Tables...................................................................

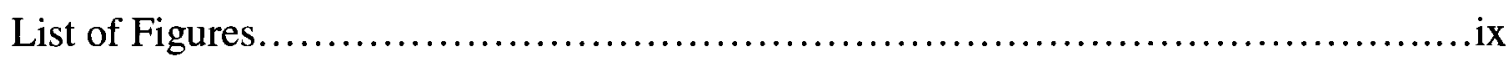

List of Appendices...........................................................

Chapter 1: General Introduction..............................................

Chapter 2: Evaluation of current pesticide registration guidelines: Comparing the response of plants to herbicides when grown singly in pots versus in microcosm communities using biomass as an endpoint

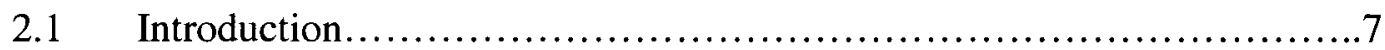

2.2 Materials and Methods.........................................

2.2.1 Plant Species and Herbicide Selection.............9

2.2.2 Screening Tests...............................10

2.2.3 Single Species Definitive Tests..................10

2.2.4 Greenhouse Microcosm Experiments..............11

2.2.5 Long-term Microcosm Experiments................12

2.2.6 Outdoor Microcosm Experiment................12

2.2.7 Chemical Analysis............................13

2.2.8 Statistical Analysis..............................14

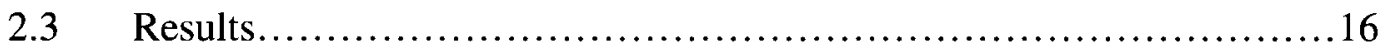

$2.4 \quad$ Discussion.....................................................

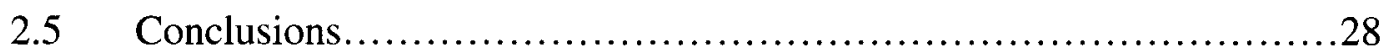


Chapter 3: An evaluation of the chlorophyll $a$ fluorescence parameter Fv/Fm as an indicator of herbicidal damage to non-target plants exposed to glyphosate and atrazine

$3.1 \quad$ Introduction........................................................ 55

3.2 Materials and Methods..............................................58

$3.3 \quad$ Results....................................................... 61

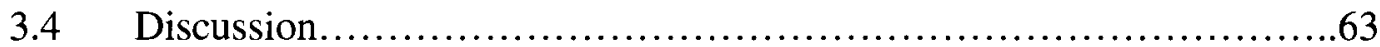

3.5 Conclusions.......................................................69

Chapter 4: Stomatal conductance as a potential tool to detect differences between non-target plants exposed to glyphosate or atrazine and grown under different conditions

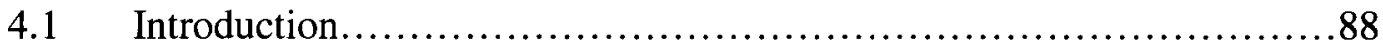

4.2 Materials and Methods............................................. 90

$4.3 \quad$ Results.......................................................... 93

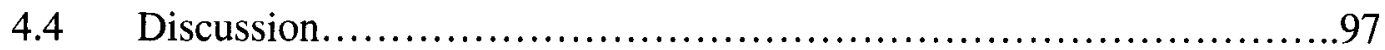

4.5 Conclusions................................................. 103

Chapter 5 General Discussion and Conclusions

$5.1 \quad$ Discussion..................................................... 124

5.2 Conclusions............................................... 127

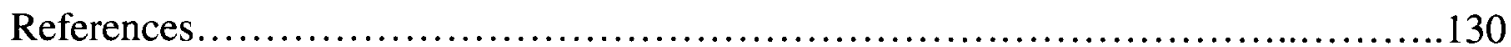




\section{LIST OF TABLES}

\section{Chapter 1:}

Table 1.1. Summary of properties of glyphosate and atrazine 6

\section{Chapter 2:}

Table 2.1. Characteristics of nine terrestrial species common to Eastern Ontario and Western Quebec.

Table 2.2. Characteristics of seven wetland species common to Eastern

Ontario and Western Quebec.

Table 2.3. Nominal and measured range of glyphosate and atrazine concentrations for each terrestrial test.

Table 2.4. Nominal and measured range of glyphosate and atrazine concentrations for each wetland test...

Table 2.5. Glyphosate and atrazine $\mathrm{IC}_{25}$ values for three terrestrial target species and total microcosm biomass, arranged by sensitivity....

Table 2.6. Glyphosate and atrazine $\mathrm{IC}_{25}$ values for three wetland target species and total microcosm biomass, arranged by sensitivity.

Table 2.7. Summary of type III sum of squares general linear models assessing the effects of test condition, species and herbicide concentration on percent control biomass for three terrestrial and three wetland target species.

Table 2.8. Summary of the main effects of test condition on percent control biomass for terrestrial and wetland target species sprayed with glyphosate and atrazine.

Table 2.9. Summary of type III sum of squares general linear models assessing the effects of test condition, species and herbicide concentration on percent control biomass for nine terrestrial and seven wetland species. 


\section{Chapter 3:}

Table 3.1. Summary of type III sum of squares general linear models assessing the effects of day, species and concentration on percentage of control Fv/Fm values for terrestrial plants treated with glyphosate and atrazine under different test conditions....

Table 3.2. Summary of type III sum of squares general linear models assessing the effects of day, species and concentration on percentage of control $\mathrm{Fv} / \mathrm{Fm}$ values for wetland plants treated with glyphosate and atrazine under different test conditions

Table 3.3. Summary of type III sum of squares general linear models assessing the effects of test condition, species and herbicide concentration on percent control Fv/Fm. Day 7 measurements

Table 3.4. Summary of type III sum of squares general linear models assessing the effects of test condition, species and herbicide concentration on percent control Fv/Fm. Day 28.

Table 3.5. Summary of the main effects of test condition and species on percent control Fv/Fm seven days after spray for terrestrial and wetland plants sprayed with glyphosate and atrazine

Table 3.6. Summary of nonparametric correlations between percent control biomass and percent control Fv/Fm for terrestrial and wetland single species tests, greenhouse, outdoor and long-term microcosm tests treated with glyphosate and atrazine

\section{Chapter 4:}

Table 4.1 Summary of type III sum of squares general linear models assessing the effects of day, species and herbicide concentration on percent control stomatal conductance for terrestrial plants treated with glyphosate and atrazine under different test conditions

Table 4.2 Summary of type III sum of squares general linear models assessing the effects of day, species and herbicide concentration on percent control stomatal conductance for wetland plants treated with glyphosate and atrazine under different test conditions 
Table 4.3. Summary of type III sum of squares general linear models assessing the effects of test condition, species and herbicide concentration on percent control conductance seven days

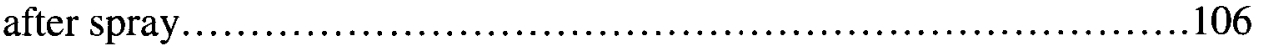

Table 4.4. Summary of the main effects of test condition and species on percent control conductance seven days after spray for terrestrial and wetland plants sprayed with glyphosate and atrazine

Table 4.5. Summary of nonparametric correlations between percent control biomass and day 7 percent control stomatal conductance for terrestrial and wetland single species tests, greenhouse, outdoor (terrestrial only) and long-term microcosm tests treated with glyphosate and atrazine. 108

\section{Chapter 5:}

Table 5.1. Summary of general linear model significant main and interaction effects of test condition, species and concentration on percent control biomass, day $7 \mathrm{Fv} / \mathrm{Fm}$ or day 7 stomatal conductance for three terrestrial and three wetland target species treated with atrazine or glyphosate. 


\section{LIST OF FIGURES}

\section{Chapter 2}

Figure 2.1. Average contribution of each terrestrial species to a) biomass and $b$ ) percent of total biomass for greenhouse microcosms sprayed with a range of glyphosate concentrations and harvested 28 days after spray.

Figure 2.2. Average contribution of each terrestrial species to a) biomass and b) percent of total biomass for long-term microcosms sprayed with a range of glyphosate concentrations and harvested 70 days after spray

Figure 2.3. Average contribution of each terrestrial species to a) biomass and b) percent of total biomass for outdoor microcosms sprayed with a range of glyphosate concentrations and harvested 28 days after spray....

Figure 2.4. Average contribution of each terrestrial species to a) biomass and $b$ ) percent of total biomass for greenhouse microcosms sprayed with a range of atrazine concentrations and harvested 28 days after spray.

Figure 2.5. Average contribution of each terrestrial species to a) biomass and b) percent of total biomass for long-term microcosms sprayed with a range of atrazine concentrations and harvested 70 days after spray

Figure 2.6. Average contribution of each terrestrial species to a) biomass and $b$ ) percent of total biomass for outdoor microcosms sprayed with a range of atrazine concentrations and harvested 28 days after spray.

Figure 2.7. Average contribution of each wetland species to a) biomass and b) percent of total biomass for greenhouse microcosms sprayed with a range of glyphosate concentrations and harvested 28 days after spray....

Figure 2.8. Average contribution of each wetland species to a) biomass and b) percent of total biomass for long-term microcosms sprayed with a range of glyphosate concentrations and harvested 60 days after spray 
Figure 2.9. Average contribution of each wetland species to a) biomass and b) percent of total biomass for greenhouse microcosms sprayed with a range of atrazine concentrations and harvested 28 days after spray.

Figure 2.10. Average contribution of each wetland species to a) biomass and b) percent of total biomass for long-term microcosms sprayed with a range of atrazine concentrations and harvested 60 days after spray.

Figure 2.11. Test and species interaction effects on estimated marginal geometric mean percent control biomass at the overall average concentration for each herbicide and habitats type

Figure 2.12. Summary of PCA characterizing terrestrial microcosm communities treated with glyphosate based on percent control biomass values calculated for each species.

Figure 2.13. Summary of PCA characterizing terrestrial microcosm communities treated with atrazine based on percent control biomass values calculated for each species

Figure 2.14. Summary of PCA characterizing wetland microcosm communities treated with glyphosate based on percent control biomass values calculated for each species....

Figure 2.15. Summary of PCA characterizing wetland microcosm communities treated with atrazine based on percent control biomass values calculated for each species.

Figure 2.16. Test and species interaction effects on estimated marginal geometric mean percent control biomass at the overall average concentration for nine terrestrial and seven wetland species grown under different microcosm conditions

\section{Chapter 3:}

Figure 3.1. Example of a typical Kautsky curve, measured on a healthy L. americanus control plant seven days after the test period began

Figure 3.2. The effects of glyphosate on average Fv/Fm values 7, 14, 21 and 28 days after spray for the terrestrial species, $G$. canadense, grown a) singly in pots, b) in greenhouse microcosms and c) in long-term microcosms .78 
Figure 3.3. The effects of glyphosate on average Fv/Fm values 7, 14, 21 and 28 days after spray for the terrestrial species, $S$. lateriflorum, grown a) singly in pots, b) in greenhouse microcosms and c) in long-term microcosms

Figure 3.4. The effects of glyphosate on average Fv/Fm values 28 days after spray for two terrestrial species, a) $G$. canadense and

b) $S$. lateriflorum, grown in outdoor microcosms

Figure 3.5. The effects of atrazine on average Fv/Fm values 7, 14, 21 and 28 days after spray for the terrestrial species, $G$. canadense, grown a) singly in pots, b) in greenhouse microcosms and c) in long-term microcosms

Figure 3.6. The effects of atrazine on average Fv/Fm values 7, 14, 21 and 28 days after spray for the terrestrial species, S. lateriflorum, grown a) singly in pots, b) in greenhouse microcosms and c) in long-term microcosms....

Figure 3.7. The effects of atrazine on average Fv/Fm values 28 days after spray for the terrestrial species, a) $G$. canadense and b) $S$. lateriflorum, grown in outdoor microcosms.

Figure 3.8. The effects of glyphosate on average Fv/Fm values for the wetland species, E. maculatum, grown a) singly in pots, b) in greenhouse microcosms and c) in long-term microcosms....

Figure 3.9. The effects of glyphosate on average Fv/Fm values for the wetland species, L. americanus, grown a) singly in pots, b) in greenhouse microcosms and c) in long-term microcosms... 85

Figure 3.10. The effects of atrazine on average Fv/Fm values for the wetland species, E. maculatum, grown a) singly in pots, b) in greenhouse microcosms and c) in long-term microcosms...

Figure 3.11. The effects of atrazine on average Fv/Fm values for the wetland species, L. americanus, grown a) singly in pots, b) in greenhouse microcosms and c) in long-term microcosms... 


\section{Chapter 4:}

Figure 4.1. The effects of glyphosate on percent control conductance 7, 14, 21 and 28 days after spray for the terrestrial plants a) A. petiolata,

b) $G$. canadense and c) $S$. lateriflorum grown singly in pots...

Figure 4.2. The effects of glyphosate on percent control conductance 7, 14, 21 and 28 days after spray for the terrestrial plants a) A. petiolata,

b) $G$. canadense and c) $S$. lateriflorum grown in greenhouse microcosms

Figure 4.3. The effects of glyphosate on percent control conductance 7, 14, $21,28,42,56$ and 70 days after spray for the terrestrial plants a) $A$. petiolata, b) $G$. canadense and c) $S$. lateriflorum grown in long-term microcosms

Figure 4.4. The effects of glyphosate on percent control conductance 7, 14, 21 and 28 days after spray for the terrestrial plants a) A. petiolata, b) $G$. canadense and c) $S$. lateriflorum grown in outdoor microcosms

Figure 4.5. The effects of atrazine on percent control conductance 7, 14, 21 and 28 days after spray for the terrestrial plants a) $A$. petiolata,

b) $G$. canadense and c) $S$. lateriflorum grown singly in pots

Figure 4.6. The effects of atrazine on percent control conductance 7, 14, 21 and 28 days after spray for the terrestrial plants a) A. petiolata,

b) $G$. canadense and c) $S$. lateriflorum grown in greenhouse microcosms

Figure 4.7. The effects of atrazine on percent control conductance 7, 14, $21,28,42,56$ and 70 days after spray for the terrestrial plants a) A. petiolata, b) $G$. canadense and c) $S$. lateriflorum grown in long-term microcosms.

Figure 4.8. The effects of atrazine on percent control conductance 7, 14, 21 and 28 days after spray for the terrestrial plants a) A. petiolata, b) $G$. canadense and c) $S$. lateriflorum grown in outdoor microcosms

Figure 4.9. The effects of glyphosate on percent control conductance 7, 14, 21 and 28 days after spray for the wetland plants a) E. maculatum,

b) $L$. americanus and c) $P$. arundinacea grown singly in pots. 
Figure 4.10. The effects of glyphosate on percent control conductance 7, 14, 21 and 28 days after spray for the wetland plants a) E. maculatum, b) $L$. americanus and c) $P$. arundinacea grown in greenhouse microcosms.

Figure 4.11. The effects of glyphosate on percent control conductance 7, 14, $21,28,42$ and 60 days after spray for the wetland plants

a) E. maculatum, b) L. americanus and c) P. arundinacea grown in long-term microcosms

Figure 4.12. The effects of atrazine on percent control conductance 7, 14, 21 and 28 days after spray for the wetland plants a) E. maculatum,

b) $L$. americanus and c) $P$. arundinacea grown singly in pots.

Figure 4.13. The effects of atrazine on percent control conductance 7, 14, 21 and 28 days after spray for the wetland plants a) E. maculatum, b) $L$. americanus and c) $P$. arundinacea grown in greenhouse microcosms

Figure 4.14. The effects of atrazine on percent control conductance 7, 14, $21,28,42$ and 60 days after spray for the wetland plants

a) E. maculatum, b) L. americanus and c) $P$. arundinacea grown in long-term microcosms

Figure 4.15. Test and species interaction effects on estimated marginal geometric means of percent control conductance at the overall average concentration for each herbicide and habitats type.... 


\section{LIST OF APPENDICES}

Appendix 1. Germination requirements, growth conditions, number of days of growth until testing stage and number of leaves at testing stage for terrestrial and wetland non-crop plants

Appendix 2. Visual rating system used to assess herbicidal damage to nine terrestrial and seven wetland plant species 28 days following exposure to $1,10,25,50,75$ or $100 \%$ of the recommended label rate of Roundup ${ }^{\circledR}$ Original (glyphosate) or AAtrex ${ }^{\circledR}$ Liquid 480 (atrazine).

Appendix 3. Standard planting arrangement used for terrestrial and wetland microcosms

Appendix 4. Comparison between outdoor and greenhouse weather conditions

A4.1. Average daily relative humidity (\%) for greenhouse and outdoor terrestrial microcosms treated with glyphosate and atrazine

A4.2. Relative light intensity $\left(\mu \mathrm{mol} \mathrm{m} \mathrm{m}^{-2} \mathrm{~s}^{-1}\right)$ taken during stomatal conductance measurements for three greenhouse and outdoor terrestrial microcosm target species $7,14,21$ and 28 days after exposure to glyphosate or atrazine

A4.3. Average, minimum and maximum daily temperatures $\left({ }^{\circ} \mathrm{C}\right)$ for greenhouse and outdoor terrestrial microcosms treated with glyphosate and atrazine 


\section{CHAPTER 1:}

\section{GENERAL INTRODUCTION}

Intensification of agriculture over the last few decades has been characterized by an increase in farm size, sophisticated mechanization as well as abandonment of crop rotation in favour of monocultures in many regions of North America (Deschênes, et al., 2003). In Canada from 1981 to 2001 , the total area of farm land increased by only $2.5 \%$ while the total number of farms decreased by $22.4 \%$ (Statistics Canada, 1981-2001), clearly indicating that farm size is increasing. Modern agriculture with high yielding crops is highly dependent on external inputs of fertilizers and pesticides (Kleijn and Snoeijing, 1997). The use of pesticides has reinforced the trend towards larger farms with less diversification as lower priced pesticides suited for monocultures have replaced higher priced labour-intensive weed control (Freemark and Boutin, 1995).

The use of synthetic organic pesticides has steadily increased worldwide since their commercial introduction following World War II. Of all the pesticides, the increased use of herbicides has been most startling in the developed world, with use tripling since the mid-seventies and now comprising over $80 \%$ of pesticide use in Canada (Boutin and Rogers, 2000; McGee, 2004). Statistics Canada (2001) estimated that herbicides were applied to almost 26 million hectares of farmland in 2000. From 19952000, herbicide usage increased by $10.7 \%$ in Ontario and $32.5 \%$ in Quebec (Statistics Canada, 2001). In 2003, glyphosate and atrazine (Table 1.1) were two of the most widely used herbicides in Ontario with an estimated $1,170,762$ and $513,950 \mathrm{~kg}$ of active ingredient applied on crops respectively (McGee, et al., 2004). 
Glyphosate ( $N$-(phosphonomethyl)glycine) is a non-selective, broad spectrum inhibitor of 5-enolpyruvylshikimate-3-phosphate synthase (EPSP). The inhibition of EPSP, an enzyme of the aromatic acid biosynthetic pathway, prevents the synthesis of aromatic amino acids needed for protein synthesis (Tomlin, 2000). The herbicidal properties of glyphosate were first reported in 1971 by Baird, et al. and production of the first Monsanto Roundup ${ }^{\circledR}$ product began in 1974 (Monsanto Company, 2002). Glyphosate became the first billion-dollar pesticide in the early 1980s (Caseley and Copping, 2000) and with the introduction of genetically modified Roundup Ready® crops, demand shows no sign of slowing down (Woodburn, 2000).

AAtrex contains the active ingredient atrazine (6-chloro-N-ethyl-N'-(1methylethyl)-1,3,5-triazine-2,4-diamine) and is a selective systemic inhibitor of photosystem II electron transport (Tomlin, 2000). Its herbicidal properties were first reported in 1957 by Gysin and Knüsli and it is predominately used in corn crops (Tomlin, 2000). Atrazine's persistence, mobility and low adsorption characteristics have led to its widespread presence in many surface and ground waters of North America (EPA, 2003).

The intensification of agriculture and urban development has placed increasing strain on non-target habitats within agroecosystems. Despite this strain, many habitats within agroecosystems remain important contributors to biodiversity. For example, Boutin, et al. (2003) found that although many streams and wetlands have been lost or degraded by the drainage of 1.5 million ha of land in the St. Lawrence Valley over the last few decades, riparian habitats contain wetland species not found in other agroecosystem habitats. Wooded riparian strips have also been found to contain high avian diversity and abundance (Deschênes, et al., 2003). Arable field boundaries are 
important in providing refuges for plant species in addition to food and shelter for numerous insect, bird and animal species (Sotherton, et al., 1988; Lagerlöf, et al., 1992; Boutin, et al., 1994; de Snoo, 1999; reviewed in Freemark and Boutin, 1995). While the longstanding belief has been that hedgerows harbour pests, it has been found that they enhance the biodiversity and abundance of many beneficial species (Boatman, et al., 1994; Duelli, 1997).

Due to their proximity to agricultural fields, non-target plants are likely to be affected by misplacement of agrochemicals through spray drift, vapour drift and surface run-off. In particular, herbicide spray drift poses a difficult ecotoxicological problem to evaluate because the exact amount of herbicide deposition depends on a number of environmental factors (Marrs and Frost, 1997) and it is difficult to separate the effects of other stress factors from those of pesticide spray drift (Follak and Hurle, 2003). Despite these difficulties, research undertaken in both Europe and North America has clearly demonstrated that herbicides and other agrochemicals can have adverse direct impacts on plants and habitats as well as indirect effects on wildlife (Sotherton, et al., 1988; Lagerlöf, et al., 1992; Boutin and Jobin, 1998; Marshall, 2001). Although a number of studies have shown that spray drift can have adverse effects on non-target habitats, environmental monitoring for the assessment of herbicide impacts on terrestrial wildlife has only recently begun (Boutin, et al., 1994; Boutin and Jobin, 1998; de Snoo and van der Poll, 1999; reviewed in Freemark and Boutin, 1995).

A number of studies have shown that exposure to herbicide spray drift and proximity to high intensity agriculture fields can alter the structure of non-target plant communities in favour of introduced and invasive species, particularly grass species 
(Marrs, et al., 1991b; Pfleeger and Zobel, 1995; Kleijn and Snoeijing, 1997; Marrs and Frost 1997; Boutin, 2006). Boutin and Jobin (1998) examined the species composition of hedgerows $1 \mathrm{~m}$ and $3 \mathrm{~m}$ from medium intensity fields, and found that $62 \%$ and $50 \%$ of the species were introduced, respectively. In woodlots near high intensity fields only $2 \%$ of the species were introduced $9 \mathrm{~m}$ from the field edge, but $45 \%$ were introduced $1 \mathrm{~m}$ from the field edge (Boutin and Jobin, 1998). Similarly, the percentage of non-native species in riparian habitats was $59-63 \%$ in habitats adjacent to agricultural fields, compared to $24-40 \%$ in habitats adjacent to watercourses (Boutin, et al., 2003).

Pesticide registration is governed by the Pest Management Regulatory Agency (PMRA) in Canada and by the Environmental Protection Agency (EPA) in the United States. Current pesticide registration guidelines were originally implemented to protect non-target plant species of economic interest (i.e. crops and ornamentals) from unintended exposure to pesticides. Unfortunately, these guidelines remain the main regulatory mechanism for protecting non-target native plants from pesticide exposure. The U.S. EPA and Organisation for Economic Co-operation and Development's (OECD) guidelines are based on testing crop species grown singly in pots under ideal greenhouse conditions (Holst and Ellwanger, 1982; OECD, 1984; EPA, 1996; OECD, 2005). Single species testing is limited because no assessment of competitive interactions is possible and the effects on ecosystem functioning cannot be evaluated (Kersting, 1982; Marrs, et al., 1989; Marrs, et al., 1991a; Marrs, et al., 1991b; Marrs, et al., 1992). Several studies have found that exposure to low levels of herbicide reduced the performance of some species in favour of weedy and/or grass species, suggesting that competitive interactions between species may potentially be altered by exposure to herbicides (Marrs, et al., 
1991b; Pfleeger and Zobel, 1995; Kleijn and Snoeijing, 1997; Marrs and Frost, 1997). Current testing is based on 21 or 28 day tests using plants at the juvenile stage so longterm effects on reproduction cannot be evaluated (Holst and Ellwanger, 1982; OECD, 1984; EPA, 1996; OECD, 2005). Furthermore, previous studies have shown poor correspondence between greenhouse testing and field studies (Kleijn and Snoeijin, 1997; Clark, et al., 2004). To date, there exists no sound scientific rationale for assuming that single species greenhouse tests provide adequate measures of protection to non-target plants.

The main objective of this research was to compare the response of plants to herbicides when they are grown singly in pots with their response when grown in a community. Further objectives were to compare the response of plants grown in communities established under greenhouse conditions for a standard 28 day test period with those established for a longer test period and with those grown under semi-natural field conditions. Biomass is a valuable destructive endpoint commonly used in phytotoxicity testing. Since biomass may have limited practicality when assessing herbicidal effects on natural communities, the use of non-destructive measurements of chlorophyll fluorescence and stomatal conductance was also investigated. 
Table 1.1. Summary of properties of glyphosate and atrazine ${ }^{1}$

\begin{tabular}{|c|c|c|}
\hline & Glyphosate & Atrazine \\
\hline \multirow{2}{*}{$\begin{array}{l}\text { Type of } \\
\text { herbicide }\end{array}$} & Non-selective systemic herbicide ${ }^{a, b}$ & Selective systemic herbicide ${ }^{\text {a, } c}$ \\
\hline & $\begin{array}{l}\text { Contact herbicide, absorbed by } \\
\text { leaves }{ }^{a, b}\end{array}$ & $\begin{array}{l}\text { Absorbed mainly through roots but } \\
\text { also through leaves }{ }^{\text {a }}\end{array}$ \\
\hline $\begin{array}{l}\text { Mode of } \\
\text { action }\end{array}$ & $\begin{array}{l}\text { Inhibits } 5 \text {-enolpyruvylshikimate- } 3 \text { - } \\
\text { phosphate synthase (EPSP), disrupting } \\
\text { the aromatic acid biosynthetic pathway } \\
\text { by preventing synthesis of essential } \\
\text { aromatic amino acids needed for } \\
\text { protein synthesis }{ }^{\text {a }}\end{array}$ & $\begin{array}{l}\text { Inhibits photosynthetic electron } \\
\text { transport at the photosystem II } \\
\text { receptor site }^{\text {a }}\end{array}$ \\
\hline Uses & $\begin{array}{l}\text { Control of annual and perennial } \\
\text { grasses as well as broadleaf weeds. } \\
\text { Mainly used pre-emergence (except } \\
\text { for GM crops) but also pre-harvest as } \\
\text { a desiccant }^{a, b}\end{array}$ & $\begin{array}{l}\text { Selective control of broad-leaved } \\
\text { weeds and annual grasses both pre-and } \\
\text { post-emergence a, c }\end{array}$ \\
\hline $\begin{array}{l}\text { Approved } \\
\text { uses in } \\
\text { Canada }\end{array}$ & $\begin{array}{l}\text { Pre-planting in all crops; post-harvest } \\
\text { in annual crops; pre-harvest for a } \\
\text { number of cereal, oilseed and legume } \\
\text { crops; wood ornamentals, vine and } \\
\text { berry crops; industrial rights-of-way; } \\
\text { minimum till crops; GM crops }{ }^{\text {b }}\end{array}$ & Silage, field and sweet corn ${ }^{c}$ \\
\hline $\begin{array}{l}\text { Solubility in } \\
\text { water }\end{array}$ & $11.6 \mathrm{~g} / \mathrm{L}\left(25^{\circ} \mathrm{C}\right)^{\mathrm{a}}$ & $0.033 \mathrm{~g} / \mathrm{L}\left(22^{\circ} \mathrm{C}\right)^{\mathrm{a}}$ \\
\hline \multirow[t]{4}{*}{$\begin{array}{l}\text { Environmental } \\
\text { Fate }\end{array}$} & Half-life of 3-174 days in soil ${ }^{a}$ & $\begin{array}{l}\text { Half-life of } 16-77 \text { days in soil (field } \\
\text { data) }{ }^{a} ; 90-120 \text { days (laboratory data) }\end{array}$ \\
\hline & Half-life of a few-91 days in water ${ }^{a}$ & $\begin{array}{l}\text { Half-life of 10-105 days in surface } \\
\text { water; 105->200 days in ground water }\end{array}$ \\
\hline & $\begin{array}{l}\text { Adsorbs strongly to soil, residues are } \\
\text { immobile }^{\mathrm{d}}\end{array}$ & $\begin{array}{l}\text { Mobile and persistent in the } \\
\text { environment }{ }^{\mathrm{e}}\end{array}$ \\
\hline & Degraded through microbial activity ${ }^{d}$ & $\begin{array}{l}\text { Degraded through microbial activity } \\
\text { under aerobic conditions }\end{array}$ \\
\hline $\begin{array}{l}\text { Rate of } \\
\text { Application (g } \\
\text { ai/ha) }\end{array}$ & $\begin{array}{l}267-1246 \mathrm{~g} \text { ai /ha for annual weeds }{ }^{\mathrm{b}} \\
890-4272 \mathrm{~g} \text { ai / } \mathrm{ha} \text { for perennial weeds }\end{array}$ & $988-1458 \mathrm{~g}$ ai $/ \mathrm{ha}^{\mathrm{c}}$ \\
\hline
\end{tabular}




\section{CHAPTER 2:}

\section{EVALUATION OF CURRENT PESTICIDE REGISTRATION GUIDELINES: \\ COMPARING THE RESPONSE OF PLANTS TO HERBICIDES WHEN GROWN SINGLY IN POTS VERSUS IN MICROCOSM COMMUNITIES USING BIOMASS AS AN ENDPOINT}

\subsection{INTRODUCTION}

Microcosms are controlled, reproducible laboratory systems which attempt to simulate ecosystems (Gillett, et al., 1997). Laboratory micro-ecosystems originated in the 1950s and 1960s and have since gained popularity (Dubey, 1984). The common thread between microcosm studies is that they are designed to manipulate an individual environmental axis and explore the role it plays in structuring communities (Fraser and Keddy, 1997). The main goal of these studies is to bridge the gap between theory and nature (Fraser and Keddy, 1997) and potentially between laboratory tests and the field (Gillett, et al., 1977). A microcosm study involving only a few plant species is an effective way to investigate interactions among species while avoiding the inherent difficulty of natural systems containing complex plant communities (Davies and Blackburn, 1989; Marrs and Frost, 1997).

Microcosms have several advantages over both single species testing and field testing. By grouping species with similar life-history traits, relative growth rates or competitive ability, it is possible to interpret results and draw meaningful conclusions more easily (Grime, 1993; Fraser and Keddy, 1997). Microcosms are more realistic than single species testing because the amount of herbicide intercepted by a given plant is affected by neighbouring plants (Marrs and Frost, 1997). Background variability and 
vegetation heterogeneity can be minimized while a realistic spray application can be assessed (Marrs, et al., 1991b).

It is unclear if current pesticide registration guidelines, using crop-species grown singly in pots provide adequate measures of protection for non-target plants. The purpose of this study was to compare the response of plants to herbicides when they were grown singly in pots versus when grown in microcosm communities to determine if single species tests correspond well with more realistic conditions. Since it has been shown that some recovery from spray drift often occurs (Marrs and Frost, 1997), greenhouse microcosm experiments were conducted for both a standard test period ( 28 days) and a longer test period (60 or 70 days). It has been hypothesized that chemical effects in the field are reduced (Garrod, 1989) but others have found that plants are more sensitive in the field compared to greenhouse conditions (e.g. Kjaer, et al., 1998). A review of plant toxicity literature by Clark, et al. (2004), found that field and greenhouse results were not in agreement and that comparisons between studies conducted at the same time of year in the same climatic zone were needed. The response of microcosms, established in outdoor, semi-natural field conditions was compared with the response of greenhouse microcosms to help address this gap in test guidelines.

\subsection{MATERIALS AND METHODS}

This study was conducted in the National Wildlife Research Centre (NWRC) greenhouse and in the outdoor experimental compound at Carleton University in Ottawa, ON, Canada from May 2005 to May 2006. A $16 \mathrm{hr}$ photoperiod was maintained in the 
greenhouse using supplemental artificial lighting consisting of $60 \mathrm{~W}$ incandescent bulbs and $215 \mathrm{~W}$ cool white fluorescent bulbs.

\subsubsection{Plant Species and Herbicide Selection}

Nine terrestrial and seven wetland plant species common to agroecosystems of Eastern Ontario and Western Quebec were selected for this study based on availability of seed from commercial suppliers and ease of germination and growth as determined by pilot studies (Appendix 1). The majority of the species selected were native species desirable from a conservation perspective, but common terrestrial and wetland invasive species were also selected because they are representative of agroecosystems (Tables 2.1 and 2.2). Definitive and microcosm experiments for each habitat (terrestrial or wetland) and herbicide (glyphosate or atrazine) were conducted at the same time, or as close as possible, to reduce temporal variability (Tables 2.3 and 2.4). Safer's natural insecticidal soap, containing potassium salts of fatty acids was used on rare occasion to control aphids but insect pest populations were nearly always managed using biological control. The following beneficial insects were used as needed: Aphidius matricariae Haliday (aphid parasitic wasp); Aphidoletes aphidimyza (Rondani) Diptera (aphid predator midge); Hippodamia convergens Guerin (ladybugs, general predator especially of aphids); Hypoaspis miles (Berlese) Acari (thrip and fungus gnat predator mite); and Neoseiulus cucumeris (Oudemans) Acari (thrip predator mite).

Two commercially available herbicides, AAtrex ${ }^{\circledR}$ Liquid 480 (Syngenta Crop Protection Canada, Inc., Guelph, ON, Canada) and Roundup Original® (Monsanto Company, Mississauga, ON, Canada) were purchased locally and used throughout this

study (Refer to Table 1.1 in Chapter 1). AAtrex contains $470.4 \mathrm{~g} / \mathrm{L}$ of the active 
ingredient atrazine (6-chloro-N-ethyl-N'-(1-methylethyl)-1,3,5-triazine-2,4-diamine) (Syngenta Crop Protection Canada Inc., 2002). Roundup Original contains 356 g/L of the active ingredient glyphosate ( $N$-(phosphonomethyl)glycine) in the form of its isopropylamine salt (Monsanto, 2001). The surfactant, Agral® 90 (nonylphenoxy polyethoxy ethanol) was added to Roundup Original ${ }^{\circledR}$ solutions as recommended on the product label (approximately $0.5 \%$ by volume) (Monsanto, 2001).

\subsubsection{Screening Tests}

A sensitivity range-finding screening test was conducted for each species, with each herbicide separately. Plants were grown singly in $10 \mathrm{~cm}$ square plastic pots filled with a 1:3 mixture of sand to Pro-Mix (containing approximately $9.5 \%$ organic matter and consisting of soil that is $75 \%$ sand, $17 \%$ silt and $8 \%$ clay) (Premier Horticulture Inc., Quakertown, PA, USA). Plants were sprayed with a one-time application of herbicide when they reached a size comparable to the 4-6 leaf stage typically used in pesticide testing (4- 15 leaves depending on the species) using a track spray booth equipped with a TeeJet $8002 \mathrm{E}$ flat-fan nozzle delivering $6.75 \mathrm{ml} / \mathrm{m}^{2}$ pressurized to $206.84 \mathrm{KPa}$ (deVries Manufacturing, Hollandale, MN, USA). Treatments consisted of six doses $(1,10,25,50$, 75 and $100 \%$ of the average recommended label rate for perennial weeds) and a control, with three replicates per treatment. Visual herbicidal effects were assessed on day 28 using a rating scale ranging from ' 0 ' for no effect and ' 9 ' for mortality (Appendix 2).

\subsubsection{Single Species Definitive Tests}

Three terrestrial (A. petiolata, G. canadense, S. lateriflorum) and three wetland (E. maculatum, L. americanus, $P$. arundinacea) species were chosen as target species for detailed analysis as follows. For each habitat type, an invasive species along with two 
other species from different families and with different growth forms were chosen as target species. A single species definitive test was conducted for each target speciesherbicide combination. Each definitive test consisted of five doses following a geometric progression and a control with six replicates each. Doses were selected by estimating the 20, 50 and 80 inhibition concentration $\left(\mathrm{IC}_{20}, \mathrm{IC}_{50}\right.$ and $\left.\mathrm{IC}_{80}\right)$ from day 28 visual assessment data using linear interpolation to achieve a 20-80\% effect (Tables 2.3 and 2.4). Plants were grown and sprayed as above. Plants were fertilized on days 14 and 21 after spray to ensure that nutrients were not limiting (using Plant-Prod, containing a 2020-20 mix of nitrogen, phosphoric acid and soluble potash at a concentration of $3 \mathrm{ml} / 5 \mathrm{~L}$, Plant Products Co. Ltd., Brampton, ON, Canada). Twenty-eight days following herbicide spray, all above-ground biomass was harvested and dried to a constant weight at approximately $70^{\circ} \mathrm{C}$.

\subsubsection{Greenhouse Microcosm Experiments}

Microcosm experiments were conducted separately for each herbicide and each habitat type. The germination of all nine terrestrial and all seven wetland species was timed so that all species of a given habitat type would reach a size appropriate to be sprayed at the same time (Appendix 1). Several weeks prior to spray, seedlings of each species were transplanted into round $25 \times 13 \mathrm{~cm}$ plastic microcosm pots. Seedlings were transplanted according to a standardized planting arrangement where the invasive species were assigned to the middle of the pot and the other species were randomly assigned positions in a circular arrangement around the perimeter of the pot (Appendix 3). For glyphosate, five doses following a geometric progression were selected to span a $20-80 \%$ inhibition effect for all species. For atrazine, where species had a wider range of 
sensitivities, five doses following a geometric progression were selected to span a 20 $80 \%$ inhibition effect for the target species (Tables 2.3 and 2.4). Microcosm pots were sprayed as in the screening tests, once the majority of the species reached the testing stage. Microcosms were fertilized as in the definitive tests. Above-ground biomass was harvested separately for all species at the end of the 28 day test period and dried to a constant weight at approximately $70^{\circ} \mathrm{C}$.

\subsubsection{Long-term Microcosm Experiments}

The greenhouse microcosm experiments were repeated as indicated above for both atrazine and glyphosate. Terrestrial microcosms were maintained for 70 days following spray whereas wetland microcosms were maintained for 60 days following spray. All long-term microcosms were fertilized on days 14, 21, 35 and 49 as well as on day 63 for the terrestrial microcosms. At the end of the test period all-above ground biomass was harvested and dried separately for each species.

\subsubsection{Outdoor Microcosm Experiment}

The outdoor microcosm experiment was conducted for the terrestrial species only. Microcosms were established as in the greenhouse microcosm experiment. Once transplanted into the microcosm pots, plants were left for one week in the greenhouse and then moved to an outdoor experimental compound at Carleton University. Microcosm pots were placed in $2.5 \times 1.5 \times 0.9 \mathrm{~m}$ wooden cages covered in chicken wire and elevated approximately $1 \mathrm{~m}$ from the ground to protect from herbivores. Microcosm pots were moved back to the greenhouse to be sprayed, left 24 hours un-watered following spray and then moved back outdoors for the duration of the test period. 
A HOBO® Micro Station (Onset Computer Corporation, Bourne, MA, USA) equipped with a temperature/RH smart sensor and a wind speed/direction smart sensor was used to monitor outdoor temperature, humidity and wind speed and was compared to the temperature and humidity in the greenhouse measured using a HOBO® H8 Pro Series Logger (Onset Computer Corporation, Bourne, MA, USA). Outdoor growing conditions were characterized by low exposure to wind (average $0.258 \mathrm{~m} / \mathrm{s}$ ). Relative humidity was higher outside than in the greenhouse (average of $73.0 \%$ versus $61.7 \%$ ) due to the use of fans in the greenhouse (Appendix 4). Average daily temperature ranged from 15.1$28.6^{\circ} \mathrm{C}$ outdoors and $19.0-33.7^{\circ} \mathrm{C}$ in the greenhouse (Appendix 4). Light measurements were taken using an unleveled, unfiltered GaAsP photodiode light sensor $\left(\mu \mathrm{mol} \mathrm{m} \mathrm{m}^{-2} \mathrm{~s}^{-1}\right)$ during stomatal conductance measurements with an AP4 cycling diffusion porometer (Delta-T Devices, Cambridge, England). Light intensity was approximately 4.43 times higher outdoors than in the greenhouse (Appendix 4). Outdoor microcosms were exposed to periodic rainfall but were also watered daily as required.

\subsubsection{Chemical Analysis}

Two $12.5 \mathrm{~cm}$ diameter filter papers (P8 creped, Fisher Scientific, Pittsburgh, PA, USA) were placed in the spray booth at the height of the pots being sprayed for each concentration for all single-species definitive and microcosm tests. For the terrestrial species component of this study one of the two filter papers was randomly selected and the herbicide extracted using liquid chromatography mass spectrometry (LC-MS) to determine the actual concentration reaching the plants (Table 2.3). For the wetland species component of this study, high performance liquid chromatography (HPLC) was used to determine the concentration of atrazine reaching the plants using the average 
value measured from both filter papers (Table 2.4). Chemical analysis is pending for wetland glyphosate experiments. Chemical analysis was provided by Suzanne Trudeau, France Maisonneuve and Catherine Corrigan at the National Wildlife Research Centre.

\subsubsection{Statistical Analysis}

Twenty-five percent inhibition concentrations $\left(\mathrm{IC}_{25} \mathrm{~s}\right)$ were calculated for each test and target species (as well as for total microcosm biomass) using non-linear regression (SYSTAT 11). Dose-response curves were fit individually with one of five models (linear, exponential, logistic, gompertz or hormesis). The approach followed was an adaptation and modification of Stephenson, et al., 2000 and is outlined in Environment Canada, 2005. Data were square-root or log transformed if necessary to meet the assumptions of normality of residuals and homogeneity of variance.

Since there is currently no widely accepted method for comparing $\mathrm{IC}_{25}$ values (Environment Canada, 2005), general linear models were used to determine if the response of plants to herbicides differed between single species and microcosm tests for the target species selected (SPSS 14.0). A separate model was constructed for each herbicide and habitat type (terrestrial or wetland). Test condition and species were entered into the model as fixed categorical predictor variables while the measured concentration obtained from chemical analysis was entered as a covariate (i.e. continuous quantitative predictor). Concentration was modeled in log grams of active ingredient per hectare $(\log g$ ai/ha) because the doses selected for each test were approximately loglinear. The dependent variable was percent of control biomass, calculated by dividing each biomass value by the average control value for the related test. Percent control biomass values were used because mathematically, there is a large gap between the 
control and the first logged concentration. This affected the linearity of the covariate and resulted in artificially low $\mathrm{R}^{2}$ values. Percent control values eliminated this problem, as well as size effects related to the test conditions.

The analysis of covariance (ANCOVA) assumption of homogeneity of slopes was assessed for each model. If the assumption was met, a type III sum of squares ANCOVA was conducted. In cases where the assumption was not met (i.e. there was an interaction between one or more predictor variable and the covariate), the interaction term(s) was included in the model. For each model, the general linear model assumption of normality of residuals and homogeneity of variance was assessed using a Shapiro-Wilk's test and Levene's test as well as through a visual assessment of the residuals. The dependent variable was transformed to best meet the assumptions using a square root, logarithmic $(\log (y+1))$ or inverse $(-1 / y+1)$ transformation. The differences between the main effects of test and the interaction between test and species were assessed by calculating the estimated marginal geometric mean for each level of the variables and performing a Sidak pair-wise comparison. Means were calculated at the overall average measured concentration for a given herbicide-habitat combination for comparability between tests.

Multivariate analysis was used to examine the relationship between individual microcosm communities, herbicide concentration and test condition. Principal components analyses (PCA) (with correlation coefficient cross-product matrix) (PCORD, v. 4) were performed for each herbicide and habitat type separately. Unlike traditional PCA, which typically uses presence/absence species data from many sites, percent of control biomass data calculated for all nine terrestrial or seven wetland species were used to characterize each microcosm community. Since only percent control 
biomass data was used (i.e. no predictor variables or log-linear covariates), values were included for individual control microcosms as a measure of the variability between controls. Data were square root transformed to reduce skewness and kurtosis. The broken-stick method was used to determine if a particular axis represented more variation than was expected by chance (Jackson, 1993). This technique is quite conservative, therefore one more axis than recommended by this method was used for interpretation of each PCA. A one-way analysis of variance (ANOVA) was conducted for each PCA to determine if test conditions differed along axis 2 for mid-concentration treated microcosms. The independent variable was the axis 2 score for microcosms treated with the middle three concentrations and test condition was the fixed categorical predictor variable. Sidak post-hoc tests conducted where necessary and data were transformed to best meet the assumptions of normality of residuals and homogeneity of variance.

The effects of concentration, species and test condition were examined for the entire microcosm community similarly to the general linear models for the target species as described above. Percent control biomass values were calculated for all nine terrestrial and all seven wetland species.

\subsection{RESULTS}

Non-linear regression was used to calculate $\mathrm{IC}_{25} \mathrm{~S}$ for each target species grown under the different test conditions as well as for total biomass for each different type of microcosm (Tables 2.5 and 2.6). For the terrestrial target species used in this study, definitive single species tests never yielded the lowest $\mathrm{IC}_{25}$ value compared to one of the microcosm tests (Table 2.5). In general, $\mathrm{IC}_{25}$ values generated from greenhouse 
microcosms tended to be lower than those for the other tests (Table 2.5). Although both outdoor and long-term microcosm $\mathrm{IC}_{25}$ values tended to be higher than both definitive single species and greenhouse microcosms, the pattern was not consistent between species and herbicides (Table 2.5).

In contrast to the terrestrial tests, wetland single species definitive test $\mathrm{IC}_{25} \mathrm{~s}$ were not consistently higher than those for greenhouse microcosms (Table 2.6). For the target species selected, $\mathrm{IC}_{25}$ values for single species definitive tests and greenhouse microcosms were generally comparable (Table 2.6). Recovery occurred in some of the long-term microcosms, leading to higher $\mathrm{IC}_{25} \mathrm{~s}$ but not in others. The wetland $\mathrm{IC}_{25}$ values, particularly for glyphosate, were characterized by being quite low, often well below $10 \%$ of the recommended label rate (Table 2.6).

It is interesting to note that the invasive species for each habitat type, A. petiolata and $P$. arundinacea were far less sensitive to atrazine in long-term microcosms compared to any other test (Tables $2.5,2.6$ ). For both herbicide and habitat types, $\mathrm{IC}_{25} \mathrm{~s}$ generated using the total biomass of all species follow patterns of sensitivity similar to $\mathrm{IC}_{25} \mathrm{~s}$ calculated for individual species (Table 2.5 and 2.6; Figures 2.1a-2.10a).

General linear models were constructed to determine the effects of concentration, target species and test condition on percent control biomass (Table 2.7). In all four cases (i.e. for each herbicide and habitat combination), there were significant main effects of test condition, species and concentration on percent control biomass (Table 2.7). Concentration had the largest effect on biomass as indicated by the large F-statistics compared to the other variables (Table 2.7). In each case, there was also a significant interaction between test and species indicating that individual species respond differently 
to the test conditions (Table 2.7; Figure 2.11). There was no consistent pattern of sensitivity for all species and for some (e.g. both invasive species treated with atrazine), sensitivity varied widely among test conditions (Figure 2.11). In three of the four analyses, there were also significant interactions between test and concentration and between species and concentration (Table 2.7). In these models, the response to concentration depended on the test condition and the response to concentration was also species-dependent.

Overall differences between test conditions were concentration-dependent because there were significant interactions between the covariate concentration and the categorical predictor variables (except in the case of atrazine wetland tests). Differences between test conditions were evaluated using the estimated marginal means calculated at the overall average concentration (i.e. at one point along the dose-response curve). In each case, greenhouse microcosms were the most sensitive test and had the overall largest reduction in percent of control biomass (Table 2.8). Single species definitive tests were generally more similar to long-term or outdoor microcosms than were greenhouse microcosms (Table 2.8).

$\mathrm{R}^{2}$ values for the models were generally high indicating that test condition, species and concentration explained the majority of the variation in percent control biomass (Table 2.7 ). The $\mathrm{R}^{2}$ value for the atrazine terrestrial test model was lower than the others because concentration explained less variation than it did in the other models (Table 2.7) and dose-responses were less pronounced (Figures 2.4a-2.6a).

Multivariate analysis of the species composition of individual microcosms (characterized by percent control values) illustrated the relationship between microcosms 
along theoretical explanatory axes. In each analysis, microcosms were generally positioned from left to right from lowest to highest herbicide concentration along Axis 1 (Figures 2.12-2.15). The variation explained by Axis 1 was very similar for three of the four analyses. Axis 1 explained $64.8 \%, 68.3 \%$ and $64.1 \%$ of the variation in the microcosms for glyphosate terrestrial, glyphosate wetland and atrazine wetland microcosms respectively and corresponded with clear dose-response patterns (Figures 2.1a-2.3a; 2.7a-2.8a, 2.9a-2.10a). Axis 1 explained less variation in atrazine terrestrial microcosms (Figure 2.13) and corresponded with less pronounced dose-response patterns (Figures 2.4a-2.6a).

In all four analyses, Axis 2 explained approximately $12 \%$ of the variation (Figures 2.12-2.15). Although the broken-stick values were less than the eigenvalues (refer to 2.2.8), some patterns emerged. There appeared to be little separation between the greenhouse and outdoor microcosms (Figures 2.12 and 2.13). For all four analyses, there was some separation between greenhouse/ outdoor and long-term microcosms along Axis 2, particularly at mid-range concentrations (Figures 2.12-2.15). Axis 2 scores at the middle three concentrations were significantly different between tests for both glyphosate terrestrial and glyphosate wetland microcosms $\left(F=42.441, \mathrm{df}=2,51, \mathrm{P}<0.001, \mathrm{R}^{2}=0.625\right.$ and $\mathrm{F}=33.822, \mathrm{df}=1,34, \mathrm{P}<0.001, \mathrm{R}^{2}=0.499$ respectively). For the glyphosate terrestrial microcosms, greenhouse and outdoor microcosms were not significantly different from each other $(\mathrm{P}=0.695)$, while both were significantly different from longterm microcosms $(\mathrm{P}<0.001)$. Results from ANOVAs for both atrazine terrestrial and atrazine wetland microcosms indicated that there was no difference between test conditions and the low $\mathrm{R}^{2}$ values suggest that test condition explains little variation in 
axis $2\left(\mathrm{~F}=1.283, \mathrm{df}=2,51, \mathrm{P}=0.286, \mathrm{R}^{2}=0.048\right.$ and $\mathrm{F}=1.442, \mathrm{df}=1,34, \mathrm{P}=0.238, \mathrm{R}^{2}=$ 0.041). These findings can be highlighted in terrestrial glyphosate microcosms where $L$. vulgare contributed more to total biomass in long-term microcosms (at the expense of species such as E. graminifolia and $G$. canadense) compared to greenhouse microcosms (Figures $2.1 \mathrm{~b}$ and $2.2 \mathrm{~b}$ ). For wetland microcosms treated with atrazine, $P$. arundinacea was much more dominant and $C$. glabra less dominant in long-term microcosms than in the greenhouse microcosms (Figures $2.9 \mathrm{~b}$ and 2.10). However, individual microcosms were quite variable and not clearly separated along axis 2 (Figure 2.15). The underlying relationships between variables were examined further in general linear models.

General linear models were constructed to explore the effects of concentration, test conditions and species on percent control biomass using data for all nine terrestrial or all seven wetland species. As in similar models constructed with target species and including single species tests, concentration had the largest effect on biomass as reflected by very high F-statistics (Table 2.9). There were significant differences between glyphosate treated tests (Table 2.9) and all tests of each model were significantly different from each other at $\mathrm{P}<0.05$. The means at the average concentration followed the same pattern of sensitivity as the means in Table 2.8 , with greenhouse microcosms being the most sensitive followed by the long-term test for terrestrial glyphosate tests and the outdoor test for the terrestrial atrazine tests. While test conditions were not significantly different for atrazine treated tests, there were weak but significant three-way interactions, indicating that the response of a particular species to concentration is dependent on the test condition (Table 2.9). There were three significant interactions between test and species (Table 2.9) and it can be observed that while means for some 
species were similar between tests, means for others differed widely (Figure 2.16). There were significant differences between species and significant species-concentration interactions for three of the four analyses (Table 2.9). In contrast to when single species tests were included and with only target species, there was only one significant interaction between test and concentration (Table 2.9). $\mathrm{R}^{2}$ values were slightly lower (Table 2.9) than when only target species were used (Table 2.7) and this may be associated with reduced model fit due to increased variability in response when more species were included in the model.

\subsection{DISCUSSION}

Current pesticide registration guidelines are focused on the evaluation of inhibition concentration values (generally $\mathrm{IC}_{25} \mathrm{~s}$ or $\mathrm{IC}_{50} \mathrm{~s}$ ) generated from crop species grown singly in pots for 21 or 28 day test periods. Two assumptions of this study were that non-crop species were more representative of non-target habitats within agroecosystems than crop species and that microcosms were more realistic than single species tests. The results of this study have demonstrated that single species tests are able to provide an estimate of the sensitivity of a given species to glyphosate and atrazine. However, differences in the response of a species to test conditions may have important implications for accurate risk assessment and will be discussed below.

For the terrestrial species, definitive single species tests never yielded the lowest $\mathrm{IC}_{25}$ indicating that they do not necessarily represent the most sensitive, "worst-case" scenario. This trend was not consistent for the wetland species but in some cases, definitive single species tests underestimated sensitivity (e.g. $L$. americanus treated with 
glyphosate). To my knowledge no other study has directly compared the response of macrophytes to herbicides when grow singly versus in a community with other species. However, Larsen, et al., 1986 compared atrazine response of single species algal cultures with microcosms and experimental ponds and found that there was a "similarity" among tests and that in some cases single species tests were the most sensitive while in others they were the least sensitive.

Greenhouse microcosms were generally sensitive (i.e. yielding low $\mathrm{IC}_{25} \mathrm{~s}$ ) for both terrestrial and wetland species. When test conditions were compared in general linear models, estimated marginal means were always lower for greenhouse microcosms compared to single species tests and were significantly lower in three of four models. Plants may be under increased stress when grown in microcosms. Keddy (2001) theorized that the presence of neighbours increased the strain of abiotic factors, such as herbicide drift. Differences in species sensitivity may also alter the outcome of competition. Breeze, et al. (1990) found that herbicide treated plants were more severely affected when the number of untreated individuals around them was increased and concluded that competition stress modified the dose-response such that plants would be more severely affected when grown in a community compared to when grown singly in pots. Four individuals of the same or two different species (Cynosurus cristatus, Lolium perenne or Trifolium pretense), were grown in different combinations of treated and untreated individuals (Breeze, et al. 1990). Biomass of the entire pot was plotted against the ratio of the competing species in de Wit replacement diagrams (Breeze, et al. 1990). This study was limited because biomass was not measured for the individual target species and no comparison was made between multi-species and single species tests. 
For the terrestrial species, $\mathrm{IC}_{25} \mathrm{~s}$ and geometric means generated for outdoor microcosms were generally higher than for greenhouse microcosms, although the total biomass $\mathrm{IC}_{25}$ was quite comparable for glyphosate. The results for the target species contradict those of Kjaer, et al., 1998 who found that Fallopia convolvulus was more sensitive to copper in the field than in laboratory tests due to stressors in the field and also contradict Fletcher, et al., 1990 who analyzed published papers and found that plants were more sensitive in the field $55 \%$ of the time and more sensitive in the greenhouse only $30 \%$ of the time. Part of this discrepancy may be related to differences between the artificial conditions of the outdoor microcosms and actual field conditions. However, a review of literature by Clark, et al., 2004 found that greenhouse $\mathrm{EC}_{25}$ s were 3-29 times lower than the lowest field study value.

Sharma and Singh (2001) found that plants grown under high temperatures were taller, grew faster and absorbed and translocated more glyphosate than those at lower temperatures. In this study, temperatures were higher in the greenhouse than outdoors (Refer to 2.2.6; Appendix 4) but this did not correspond with increased biomass, as outdoor control plants weighed more than greenhouse control plants (Figure 2.3a, 2.6a vs. 2.1a, 2.4a). However, greenhouse plants were taller, greener and had more leaves than outdoor plants which were shorter, more prostrate and had thicker leaves (visual observations). This, along with higher temperatures may have corresponded with increased translocation of herbicide in the greenhouse. Smaller, thicker leaves outdoors may have contributed to decreased absorption of both herbicides but leaching of atrazine from the soil may also have had an impact. Outdoor microcosms were watered as needed but were also exposed to some heavy rainfall. Fewer overall differences were observed 
between greenhouse and outdoor microcosms treated with glyphosate than those treated with atrazine. Glyphosate binds to soil particles and thus would not leach from the microcosm pots but is inactivated in soil. In contrast, atrazine would not bind to soil particles and although it is residual and active in soil, it would likely leach from the system following heavy rainfall.

$\mathrm{IC}_{25} \mathrm{~S}$ and estimated marginal means were often higher for long-term microcosms than for greenhouse microcosms indicating that some recovery occurred. Similarly, Marrs, et al. (1991a) found that plants under various treatments recovered from exposure to glyphosate, MCPA and mecoprop $60 \%$ of the time even though all species initially showed damage. In this study, biomass was harvested when almost half of the terrestrial and about $70 \%$ of the wetland species were flowering or developing flowers, at a time when biomass was likely near its peak. Longer-term studies with different endpoints would be needed to determine the overall effect of glyphosate or atrazine on plant performance. Previous studies have found that significant herbicidal effects can become apparent a full year after spray (Marrs, et al., 1991b; Kleijn and Snoeijing, 1997) and that reproduction can be adversely affected (Fletcher, et al., 1996; Boutin, et al., 2000). With the current microcosm design, a longer test period with reproductive endpoints such as seed number or viability would have been too influenced by constraints of the microcosm container to have been realistic. However, it is evident that some recovery of biomass occurred for both terrestrial and wetland communities treated with atrazine. Recovery of community biomass following treatment with glyphosate occurred for terrestrial but not wetland microcosms. 
General linear models indicated that there were interactions between test*species, test*concentration and species*concentration. Extrapolating from one test condition with one set of species to the field would be difficult and likely misleading due to these interactions. An analysis of a database containing toxicity data from numerous studies found that variation between species was higher than between test conditions (Fletcher, et al., 1990). The authors of an extensive study examining the effects of nineteen chemicals, including glyphosate, on thirteen algal species found that species dependent variation reached three orders of magnitude and no universally sensitive species was identified (Blanck, et al., 1984). Furthermore, as in this study, toxicity was found to strongly depend both on the species selected and on environmental factors that modified toxicity, leading the authors to question the validity of single species tests under one set of environmental conditions (Blanck, et al., 1984).

An issue that arose from the interactions observed was that current testing focuses on evaluating effects at specific concentrations (i.e. $\mathrm{IC}_{25}$ or $\mathrm{IC}_{50}$ ) rather than at environmentally relevant concentrations. Since the response at a given concentration is often species or test dependent, laboratory data may yield different results than field data. A study by Madsen and Streibig in 2000, used an empirical simulation model to predict the accumulation of the weeds, Stellaria media and Chenopodium album, in the seed bank of fields which including glyphosate-tolerant oilseed rape in its rotation. When the model included glyphosate used at $100 \%$ of the label rate, the model outcome was similar if input dose-response data were generated from the greenhouse or the field. However, if the model included glyphosate at $25 \%$ of the label rate (i.e. a rate that could occur along field margins), the outcome of the model differed widely depending on whether 
greenhouse or field dose-response data were used. This suggests that there may sometimes be little correspondence between greenhouse testing and actual field conditions at environmentally relevant concentrations.

Single species tests in general have been criticized because they measure physiological responses only (Blanck, et al., 1984) and do not account for interactions between species (Marrs, et al., 1989; Marrs, et al., 1991b; Marrs and Frost, 1997). A number of studies have shown that pesticides can modify communities in ways that would not be predictable from single species tests. Madsen and Streibig (2000) found that the relative sensitivity of two weedy species ( $S$. media and $C$. album) to glyphosate was reversed when grown in field conditions containing oilseed rape compared to when grown without oilseed rape in the greenhouse. Reuter, et al. (2006) found that while one species was more sensitive to sulfosulfuron when grown in monoculture compared to when grown in a six species community, another species was less sensitive in the community. Several studies have found that the performance of some species (often grass species), increases at low doses of herbicide, either due to hormonal stimulation or reduced interference by other species (Marrs, et al., 1991b; Pfleeger and Zobel, 1995; Kleijn and Snoeijing, 1997; Marrs and Frost, 1997).

Similar results were observed in this study where changes in community structure were sometimes observed, particularly at low to mid-range doses. This resulted in an increased contribution of some species at the expense of others, particularly for long-term microcosms. Species best able to increase their contribution to treated communities included $P$. arundinacea, a perennial invasive weedy grass species, A. petiolata, a biennial weedy invasive species, $L$. vulgare, a perennial non-native species and $R$. hirta, a 
biennial or short-lived perennial. A comprehensive examination of plant species in North America concluded that weeds were more likely to be annuals and biennials by outcompeting non-weedy vegetation through superior colonization, reproduction or survivorship (Sutherland, 2004). This study is in agreement with this generalization as well as findings in other studies suggesting that weedy species are more likely to be abundant close to areas of herbicide use (Kleijn and Snoeijing, 1997; Boutin and Jobin, 1998; Boutin et al., 2003). For A. petiolata and $P$. arundinacea, this increased performance and ability to recover, corresponded in far higher $\mathrm{IC}_{25}$ values than would be predicted by single species tests. These undesirable species would be "over-protected" by single species testing. Some desirable species, such as $L$. americanus and $S$. lateriflorum, with higher single species $\mathrm{IC}_{25} \mathrm{~s}$ and lower microcosm $\mathrm{IC}_{25} \mathrm{~s}$, would be under-protected by single species tests.

A few subtle differences existed between the results from $\mathrm{IC}_{25}$ values from nonlinear regression and estimated marginal means from general linear models. Estimated marginal means were always lowest for greenhouse microcosms, but $\mathrm{IC}_{25}$ s were not always lowest for greenhouse microcosms. General linear models indicated that there were interactions between test and concentration. This could mean that one test is more sensitive than another at a given point along the dose-response curve while not at another. Another reason for the apparent differences is related to differences in the statistical methods. Estimated marginal means are chosen based on a fixed point along the $\mathrm{x}$-axis (i.e. at the average concentration used for all different tests in a model) whereas $\mathrm{IC}_{25}$ values are based on a fixed point along the $y$-axis (i.e. where there is a $25 \%$ reduction compared to the control). In this particular study, estimated marginal means were 
advantageous because differences between tests were more likely to be evaluated at the middle of the dose-response curve where models are most reliable. If the $\mathrm{IC}_{25}$ values of each test were known a priori, and more concentrations were used to span the doseresponse curves, non-linear regression would have been preferred because it allows for modeling of non-linear relationships.

In contrast, results from general linear models and multivariate analysis, both using data for all nine terrestrial and seven wetland species, were similar. There were clear differences between test conditions for plants treated with glyphosate but not for those treated with atrazine. However, general linear models indicated that test conditions influenced other variables in all models. In the PCAs, some differences between test conditions may be reflected in Axis 2, whereas other differences (e.g. due to differences in temperature or solar radiation between tests) could be reflected in another axis. This is due to the categorical nature of test condition and limits the sensitivity of PCA.

\subsection{CONCLUSIONS}

Single species tests provide important information regarding the sensitivity of a given species to a particular herbicide. Single species tests are quite useful for screening purposes because they are inexpensive, simple and can demonstrate clear dose-response patterns uncomplicated by other factors influencing growth. However, this study and others discussed above have shown that herbicide sensitivity is highly dependent on both species and test conditions. Given that sensitivity is so heavily dependent on the particular species and test conditions used, it is unlikely that single species tests using crop species would have much relevance for assessing the risk posed to non-target 
communities. Greenhouse microcosms have been shown to be simple, reproducible laboratory systems that are small enough in scale to be used in experiments containing a range of doses and high number of replicates. Microcosms can be used in laboratory or semi-natural conditions and provide additional information regarding the effects of pesticides on non-crop species relevant to agroecosystems. Greenhouse microcosm communities were shown to be consistently sensitive to glyphosate and atrazine. Results from long-term and outdoor microcosm tests suggest that non-target plants subjected to a one-time dose of atrazine or glyphosate would generally be adequately protected if single species or greenhouse microcosm $\mathrm{IC}_{25}$ values were used in risk assessment. However, single species tests, and greenhouse microcosms to a lesser extent, do not capture the large variation likely to be found in natural systems. Results from both single species and microcosms established under different conditions need to be validated in natural systems. Subtle changes in community structure, such as an increase in weedy species, may have important long-term consequences that cannot be readily evaluated in single species or short-term microcosm tests. 
Table 2.1. Characteristics of nine terrestrial species common to Eastern Ontario and Western Quebec. ${ }^{1}$

\begin{tabular}{|c|c|c|c|c|c|}
\hline Species & $\begin{array}{l}\text { English Common } \\
\text { Name }\end{array}$ & Family & Lifespan & Habitat & Status \\
\hline $\begin{array}{l}\text { Alliaria petiolata (Bieb.) Cavara \& } \\
\text { Grande }\end{array}$ & Garlic Mustard & Brassicaceae & Biennial & Weedy, moist woods & $\begin{array}{l}\text { Non- } \\
\text { Native }\end{array}$ \\
\hline $\begin{array}{l}\text { Euthamia graminifolia }(\text { L.) Nutt. } \\
\text { var. graminifolia }\end{array}$ & $\begin{array}{l}\text { Common Flat- } \\
\text { topped Goldenrod }\end{array}$ & Asteraceae & Perennial & Open, usually moist ground & Native \\
\hline Fragaria virginiana Duchesne & Wild Strawberry & Rosaceae & Perennial & Meadows and forest openings & Native \\
\hline Geum canadense Jacq. & White Avens & Rosaceae & Perennial & Dry or moist woods & Native \\
\hline Leucanthemum vulgare Lam. & Ox-eye daisy & Asteraceae & Perennial & $\begin{array}{l}\text { Fields, roadsides and waste places. Non-native } \\
\text { but naturalized throughout most of temperate } \\
\text { North America }\end{array}$ & $\begin{array}{l}\text { Non- } \\
\text { Native }\end{array}$ \\
\hline Rudbeckia hirta L. & Black-eyed Susan & Asteraceae & $\begin{array}{l}\text { Biennial/ } \\
\text { Perennial }\end{array}$ & Open fields, sandy, well-drained soil & Native \\
\hline Solidago rugosa P. Mill. & $\begin{array}{l}\text { Wrinkle-leaved } \\
\text { Goldenrod }\end{array}$ & Asteraceae & Perennial & Common in fields and thickets & Native \\
\hline $\begin{array}{l}\text { Symphyotrichum lateriflorum (L.) } \\
\text { A. \& D. Löve var. lateriflorum }\end{array}$ & Calico Aster & Asteraceae & Perennial & $\begin{array}{l}\text { Common in open woods, dry open places and } \\
\text { beaches }\end{array}$ & Native \\
\hline $\begin{array}{l}\text { Symphyotrichum novae-angliae } \\
\text { (L.) Nesom }\end{array}$ & $\begin{array}{l}\text { New England } \\
\text { Aster }\end{array}$ & Asteraceae & Perennial & Moist, open or sometimes wooded places & Native \\
\hline
\end{tabular}

1. Information from Newcomb, 1977; Gleason and Cronquist, 1991; USDA, 2006 
Table 2.2. Characteristics of seven wetland species common to Eastern Ontario and Western Quebec. ${ }^{2}$

\begin{tabular}{|c|c|c|c|c|c|}
\hline Species & $\begin{array}{l}\text { English Common } \\
\text { Name }\end{array}$ & Family & Lifespan & Habitat & Status \\
\hline Asclepias incarnata $\mathrm{L}$. & Swamp Milkweed & Asclepiadaceae & Perennial & Open swamps, ditches and wet prairies & Native \\
\hline Chelone glabra $\mathrm{L}$. & White Turtlehead & Scrophulariaceae & Perennial & Wet Woods & Native \\
\hline $\begin{array}{l}\text { Eupatorium } \\
\text { maculatum } \mathrm{L} .\end{array}$ & Spotted Joe-Pye Weed & Asteraceae & Perennial & Moist places, especially in calcareous soils & Native \\
\hline $\begin{array}{l}\text { Eupatorium } \\
\text { perfoliatum } L .\end{array}$ & Common Boneset & Asteraceae & Perennial & Moist or wet low grounds & Native \\
\hline $\begin{array}{l}\text { Lycopus americanus } \\
\text { Muhl. }\end{array}$ & $\begin{array}{l}\text { American Water- } \\
\text { horehound }\end{array}$ & Lamiaceae & Perennial & Wet places & Native \\
\hline $\begin{array}{l}\text { Phalaris arundinacea } \\
\text { L. }\end{array}$ & Reed canary-grass & Poaceae & Perennial & $\begin{array}{l}\text { Stream banks, lake-shores, marshes, ditches } \\
\text { and moist ground }\end{array}$ & $\begin{array}{l}\text { Non-Native/ } \\
\text { Native }\end{array}$ \\
\hline Verbena hastata $\mathrm{L}$. & Common Vervain & Verbenaceae & Perennial & Moist fields, meadows, prairies and swamps & Native \\
\hline
\end{tabular}

2. Information from Gleason and Cronquist, 1991. 
Table 2.3. Nominal and measured range of glyphosate and atrazine concentrations for each terrestrial test.

\begin{tabular}{|c|c|c|c|c|}
\hline $\begin{array}{l}\text { Commercial } \\
\text { Formulation } \\
\text { (common } \\
\text { name) } \\
\text { Label Rate } \\
\end{array}$ & Test & Test Period & $\begin{array}{l}\text { Nominal Range } \\
\text { of Doses } \\
\text { (g a.i./ha) }\end{array}$ & $\begin{array}{l}\text { Measured } \\
\text { Range of Doses } \\
\text { by LC-MS (g } \\
\text { a.i./ha) }\end{array}$ \\
\hline \multirow{7}{*}{$\begin{array}{l}\text { Roundup } \\
\text { Original } \circledast \\
\text { (glyphosate) } \\
2136 \text { g a.i./ ha }\end{array}$} & $\begin{array}{l}\text { A. petiolata } \\
\text { definitive }\end{array}$ & $\begin{array}{l}\text { Sept. } 7^{\text {th }}-\text { Oct. } \\
5^{\text {th }} 2005\end{array}$ & $\begin{array}{l}(0,96,120, \\
150,188,235)\end{array}$ & $\begin{array}{l}(0,101,116, \\
130,215,220)\end{array}$ \\
\hline & $\begin{array}{l}\text { G. canadense } \\
\text { definitive }\end{array}$ & $\begin{array}{l}\text { Aug. } 15^{\text {th }}- \\
\text { Sept. } 12^{\text {th }} 2005\end{array}$ & $\begin{array}{l}(0,139,218, \\
342,538,844)\end{array}$ & $\begin{array}{l}(0,124,223, \\
381,524,954)\end{array}$ \\
\hline & $\begin{array}{l}\text { S. lateriflorum } \\
\text { definitive }\end{array}$ & $\begin{array}{l}\text { Aug. } 8^{\text {th }}-\text { Sept. } \\
5^{\text {th }} 2005\end{array}$ & $\begin{array}{l}(0,85,139, \\
224,363,587)\end{array}$ & $\begin{array}{l}(0,84,130, \\
228,358,627)\end{array}$ \\
\hline & Greenhouse & July $13^{\text {th }}-$ Aug. & $(0,85,150$ & $(0,97,163$ \\
\hline & Microcosm & $10^{\text {th }} 2005$ & $263,457,801)$ & $303,511,974)$ \\
\hline & $\begin{array}{l}\text { Outdoor } \\
\text { Microcosm }\end{array}$ & $\begin{array}{l}\text { July } 12^{\text {th }}-\text { Aug. } \\
9^{\text {th }} 2005\end{array}$ & $\begin{array}{l}(0,85,150, \\
263,457,801)\end{array}$ & $\begin{array}{l}(0,106,161, \\
216,592,775)\end{array}$ \\
\hline & $\begin{array}{l}\text { Long-Term } \\
\text { Microcosm }\end{array}$ & $\begin{array}{l}\text { Aug. } 10^{\text {th }}-\text { Oct. } \\
19^{\text {th }} 2005\end{array}$ & $\begin{array}{l}(0,85,150, \\
263,457,801)\end{array}$ & $\begin{array}{l}(0,106,170, \\
250,481,621)\end{array}$ \\
\hline \multirow{6}{*}{$\begin{array}{l}\text { AAtrex }{ }^{\circledR} \\
\text { Liquid } 480 \\
\text { (atrazine) } \\
1296 \mathrm{~g} \text { a.i./ ha }\end{array}$} & $\begin{array}{l}\text { A. petiolata } \\
\text { definitive }\end{array}$ & $\begin{array}{l}\text { Sept. } 7^{\text {th }}-\text { Oct. } \\
5^{\text {th }} 2005\end{array}$ & $\begin{array}{l}(0,71,128, \\
231,416,748)\end{array}$ & $\begin{array}{l}(0,100,187, \\
311,510,774)\end{array}$ \\
\hline & $\begin{array}{l}\text { G. canadense } \\
\text { definitive }\end{array}$ & $\begin{array}{l}\text { Aug. } 15^{\text {th }}- \\
\text { Sept. } 12^{\text {th }}\end{array}$ & $\begin{array}{l}(0,32,58,102, \\
183,325)\end{array}$ & $\begin{array}{l}(0,30,39,116, \\
173,258)\end{array}$ \\
\hline & $\begin{array}{l}\text { S. lateriflorum } \\
\text { definitive }\end{array}$ & $\begin{array}{l}\text { Aug. } 8^{\text {th }}-\text { Sept. } \\
5^{\text {th }} 2005\end{array}$ & $\begin{array}{l}(0,207,277, \\
372,499,669)\end{array}$ & $\begin{array}{l}(0,261,334, \\
358,650,989)\end{array}$ \\
\hline & $\begin{array}{l}\text { Greenhouse } \\
\text { Microcosm }\end{array}$ & $\begin{array}{l}\text { Aug. } 12^{\text {th }}- \\
\text { Sept. } 9^{\text {th }} 2005\end{array}$ & $\begin{array}{l}(0,52,93,168, \\
302,544)\end{array}$ & $\begin{array}{l}(0,50,129, \\
205,570,710)\end{array}$ \\
\hline & $\begin{array}{l}\text { Outdoor } \\
\text { Microcosm }\end{array}$ & $\begin{array}{l}\text { Aug. } 16^{\text {th }}- \\
\text { Sept. } 13^{\text {th }}\end{array}$ & $\begin{array}{l}(0,52,93,168, \\
302,544)\end{array}$ & $\begin{array}{l}(0,50,114, \\
241,381,619)\end{array}$ \\
\hline & $\begin{array}{l}\text { Long-Term } \\
\text { Microcosm }\end{array}$ & $\begin{array}{l}\text { Aug. } 11^{\text {th }}-\text { Oct. } \\
20^{\text {th }} 2005\end{array}$ & $\begin{array}{l}(0,52,93,168 \\
302,544)\end{array}$ & $\begin{array}{l}(0,59,149, \\
292,497,992)\end{array}$ \\
\hline
\end{tabular}


Table 2.4. Nominal and measured range of glyphosate and atrazine concentrations for each wetland test.

\begin{tabular}{|c|c|c|c|c|}
\hline $\begin{array}{l}\text { Commercial } \\
\text { Formulation } \\
\text { (common } \\
\text { name) } \\
\text { Label Rate } \\
\end{array}$ & Test & Test Period & $\begin{array}{l}\text { Nominal Range } \\
\text { of Doses } \\
\text { (g a.i./ha) }\end{array}$ & $\begin{array}{l}\text { Measured } \\
\text { Range of Doses } \\
\text { by HPLC (g } \\
\text { a.i./ha) }\end{array}$ \\
\hline \multirow{3}{*}{$\begin{array}{l}\text { Roundup } \\
\text { Original }{ }^{\circledR} \\
\text { (glyphosate) }\end{array}$} & $\begin{array}{l}\text { E. maculatum } \\
\text { definitive }\end{array}$ & $\begin{array}{l}\text { March } 16^{\text {th }}- \\
\text { April } 13^{\text {th }} 2006\end{array}$ & $\begin{array}{l}(0,53,94,164, \\
288,504)\end{array}$ & N/A \\
\hline & $\begin{array}{l}\text { L. americanus } \\
\text { definitive }\end{array}$ & $\begin{array}{l}\text { March } 3^{\text {rd }}- \\
\text { March } 31^{\text {st }}\end{array}$ & $\begin{array}{l}(0,49,83,147, \\
258,451)\end{array}$ & N/A \\
\hline & $\begin{array}{l}P . \text { arundinacea } \\
\text { definitive }\end{array}$ & $\begin{array}{l}2006 \\
\text { March } 13^{\text {th }}- \\
\text { April } 10^{\text {th }} 2006\end{array}$ & $\begin{array}{l}(0,43,73,124, \\
211,359)\end{array}$ & N/A \\
\hline \multirow[t]{2}{*}{$2136 \mathrm{~g}$ a.i./ ha } & $\begin{array}{l}\text { Greenhouse } \\
\text { Microcosm }\end{array}$ & $\begin{array}{l}\text { March } 16^{\text {th }}- \\
\text { April } 13^{\text {th }} 2006\end{array}$ & $\begin{array}{l}(0,51,90,156 \\
273,478)\end{array}$ & N/A \\
\hline & $\begin{array}{l}\text { Long-Term } \\
\text { Microcosm }\end{array}$ & $\begin{array}{l}\text { March } 1^{\text {st }}- \\
\text { April } 30^{\text {th }} 2006\end{array}$ & $\begin{array}{l}(0,51,90,156, \\
273,478)\end{array}$ & N/A \\
\hline \multirow{3}{*}{$\begin{array}{l}\text { AAtrex }{ }^{\circledR} \\
\text { Liquid } 480\end{array}$} & $\begin{array}{l}\text { E. maculatum } \\
\text { definitive }\end{array}$ & $\begin{array}{l}\text { March } 17^{\text {th }}- \\
\text { April } 14^{\text {th }} 2006\end{array}$ & $\begin{array}{l}(0,61,97,156, \\
249,398)\end{array}$ & $\begin{array}{l}(0,83,122, \\
215,324,486)\end{array}$ \\
\hline & $\begin{array}{l}\text { L. americanus } \\
\text { definitive }\end{array}$ & $\begin{array}{l}\text { March } 3^{\text {rd }}- \\
\text { March } 31^{\text {st }} 2006\end{array}$ & $\begin{array}{l}(0,65,97,146, \\
219,328)\end{array}$ & $\begin{array}{l}(0,85,141, \\
219,297,456)\end{array}$ \\
\hline & $\begin{array}{l}P . \text { arundinacea } \\
\text { definitive }\end{array}$ & $\begin{array}{l}\text { March } 14^{\text {th }}- \\
\text { April } 11^{\text {th }} 2006\end{array}$ & $\begin{array}{l}(0,53,86,136, \\
218,349)\end{array}$ & $\begin{array}{l}(0,70,115 \\
183,291,452)\end{array}$ \\
\hline \multirow[t]{2}{*}{$1296 \mathrm{~g}$ a.i./ ha } & $\begin{array}{l}\text { Greenhouse } \\
\text { Microcosm }\end{array}$ & $\begin{array}{l}\text { March } 17^{\text {th }}- \\
\text { April } 14^{\text {th }} 2006\end{array}$ & $\begin{array}{l}(0,66,109, \\
179,295,489)\end{array}$ & $\begin{array}{l}(0,87,144, \\
240,385,644)\end{array}$ \\
\hline & $\begin{array}{l}\text { Long-Term } \\
\text { Microcosm }\end{array}$ & $\begin{array}{l}\text { March } 2^{\text {nd }}- \\
\text { May } 1^{\text {st }} 2006\end{array}$ & $\begin{array}{l}(0,66,109, \\
179,295,489)\end{array}$ & $\begin{array}{l}(0,90,139, \\
222,368,611)\end{array}$ \\
\hline
\end{tabular}


Table 2.5. Glyphosate and atrazine $\mathrm{IC}_{25}$ values for three terrestrial target species and total microcosm biomass, arranged by sensitivity.

\begin{tabular}{|c|c|c|c|c|}
\hline Herbicide & Species & Test & $\begin{array}{l}\mathrm{IC}_{25} \text { (g ai/ha) } \\
(95 \% \\
\text { Confidence } \\
\text { Intervals) }\end{array}$ & $\begin{array}{l}\mathrm{IC}_{25} \\
\text { (Percent } \\
\text { Label } \\
\text { Rate) }\end{array}$ \\
\hline \multirow{4}{*}{ Glyphosate } & A. petiolata & $\begin{array}{l}\text { Greenhouse Microcosm } \\
\text { Definitive Single Species } \\
\text { Outdoor Microcosm } \\
\text { Long-Term Microcosm }\end{array}$ & $\begin{array}{l}135(109-167) \\
153(97-242) \\
206(125-338) \\
466(456-474)\end{array}$ & $\begin{array}{l}6.3 \% \\
7.2 \% \\
9.6 \% \\
21.8 \%\end{array}$ \\
\hline & G. canadense & $\begin{array}{l}\text { Greenhouse Microcosm } \\
\text { Definitive Single Species } \\
\text { Outdoor Microcosm } \\
\text { Long-Term Microcosm }\end{array}$ & $\begin{array}{l}139(110-175) \\
139(101-191) \\
147(123-175) \\
199(126-314)\end{array}$ & $\begin{array}{l}6.5 \% \\
6.5 \% \\
6.9 \% \\
9.3 \%\end{array}$ \\
\hline & S. lateriflorum & $\begin{array}{l}\text { Long-Term Microcosm } \\
\text { Greenhouse Microcosm } \\
\text { Definitive Single Species } \\
\text { Outdoor Microcosm }\end{array}$ & $\begin{array}{l}10(6-19) \\
80(41-156) \\
161(115-226) \\
304(155-597)\end{array}$ & $\begin{array}{l}0.5 \% \\
3.7 \% \\
7.5 \% \\
14.2 \%\end{array}$ \\
\hline & Total Biomass & $\begin{array}{l}\text { Outdoor Microcosm } \\
\text { Greenhouse Microcosm } \\
\text { Long-Term Microcosm }\end{array}$ & $\begin{array}{l}140(109-180) \\
144(114-183) \\
408(362-459)\end{array}$ & $\begin{array}{l}6.6 \% \\
6.7 \% \\
19.1 \% \\
\end{array}$ \\
\hline \multirow{4}{*}{ Atrazine } & A. petiolata & $\begin{array}{l}\text { Greenhouse Microcosm } \\
\text { Definitive Single Species } \\
\text { Outdoor Microcosm } \\
\text { Long-Term Microcosm }\end{array}$ & $\begin{array}{l}99(58-168) \\
198(127-309) \\
530(324-865) \\
\text { No Response }\end{array}$ & $\begin{array}{l}7.6 \% \\
15.3 \% \\
40.9 \% \\
>76.5 \%\end{array}$ \\
\hline & G. canadense & $\begin{array}{l}\text { Greenhouse Microcosm } \\
\text { Definitive Single Species } \\
\text { Long-Term Microcosm } \\
\text { Outdoor Microcosm }\end{array}$ & $\begin{array}{l}12(7-18) \\
73(34-160) \\
163(70-380) \\
287(194-427)\end{array}$ & $\begin{array}{l}0.9 \% \\
5.6 \% \\
12.6 \% \\
22.1 \%\end{array}$ \\
\hline & S. lateriflorum & $\begin{array}{l}\text { Greenhouse Microcosm } \\
\text { Long-Term Microcosm } \\
\text { Outdoor Microcosm } \\
\text { Definitive Single Species }\end{array}$ & $\begin{array}{l}161(39-670) \\
242(59-986) \\
243(81-729) \\
279(208-374)\end{array}$ & $\begin{array}{l}12.4 \% \\
18.7 \% \\
18.8 \% \\
21.5 \%\end{array}$ \\
\hline & Total Biomass & $\begin{array}{l}\text { Greenhouse Microcosm } \\
\text { Outdoor Microcosm } \\
\text { Long-Term Microcosm }\end{array}$ & $\begin{array}{l}132(83-211) \\
387(277-542) \\
536(324-873)\end{array}$ & $\begin{array}{l}10.2 \% \\
29.9 \% \\
41.4 \%\end{array}$ \\
\hline
\end{tabular}


Table 2.6. Glyphosate and atrazine $\mathrm{IC}_{25}$ values for three wetland target species and total microcosm biomass, arranged by sensitivity.

\begin{tabular}{|c|c|c|c|c|}
\hline Herbicide & Species & Test & $\begin{array}{l}\mathrm{IC}_{25}(\mathrm{~g} \text { ai/ha) } \\
(95 \% \\
\text { Confidence } \\
\text { Intervals) }\end{array}$ & $\begin{array}{l}\mathrm{IC}_{25} \\
\text { (Percent } \\
\text { Label } \\
\text { Rate) }\end{array}$ \\
\hline \multirow{4}{*}{ Glyphosate } & E. maculatum & $\begin{array}{l}\text { Definitive Single Species } \\
\text { Greenhouse Microcosm } \\
\text { Long-Term Microcosm }\end{array}$ & $\begin{array}{l}48(38-61) \\
90(66-121) \\
142(117-171) \\
\end{array}$ & $\begin{array}{l}2.3 \% \\
4.2 \% \\
6.6 \%\end{array}$ \\
\hline & L. americanus & $\begin{array}{l}\text { Greenhouse Microcosm } \\
\text { Long-Term Microcosm } \\
\text { Definitive Single Species }\end{array}$ & $\begin{array}{l}78(57-106) \\
82(57-117) \\
182(132-253)\end{array}$ & $\begin{array}{l}3.6 \% \\
3.8 \% \\
8.5 \%\end{array}$ \\
\hline & P. arundinacea & $\begin{array}{l}\text { Definitive Single Species } \\
\text { Greenhouse Microcosm } \\
\text { Long-Term Microcosm }\end{array}$ & $\begin{array}{l}42(33-53) \\
49(32-74 \\
72(56-91)\end{array}$ & $\begin{array}{l}2.0 \% \\
2.3 \% \\
3.4 \%\end{array}$ \\
\hline & Total Biomass & $\begin{array}{l}\text { Long-Term Microcosm } \\
\text { Greenhouse Microcosm }\end{array}$ & $\begin{array}{l}107(93-123) \\
117(92-150) \\
\end{array}$ & $\begin{array}{l}5.0 \% \\
5.5 \% \\
\end{array}$ \\
\hline \multirow{4}{*}{ Atrazine } & E. maculatum & $\begin{array}{l}\text { Greenhouse Microcosm } \\
\text { Definitive Single Species } \\
\text { Long-Term Microcosm }\end{array}$ & $\begin{array}{l}78(51-120) \\
86(53-137 \\
126(86-185) \\
\end{array}$ & $\begin{array}{l}6.0 \% \\
6.6 \% \\
9.7 \% \\
\end{array}$ \\
\hline & L. americanus & $\begin{array}{l}\text { Long-Term Microcosm } \\
\text { Greenhouse Microcosm } \\
\text { Definitive Single Species }\end{array}$ & $\begin{array}{l}53(30-92) \\
69(45-106) \\
87(65-116) \\
\end{array}$ & $\begin{array}{l}4.1 \% \\
5.3 \% \\
6.7 \% \\
\end{array}$ \\
\hline & P. arundinacea & $\begin{array}{l}\text { Definitive Single Species } \\
\text { Greenhouse Microcosm } \\
\text { Long-Term Microcosm }\end{array}$ & $\begin{array}{l}138(87-218) \\
189(120-296) \\
665(114-3890)\end{array}$ & $\begin{array}{l}10.6 \% \\
14.6 \% \\
51.3 \%\end{array}$ \\
\hline & Total Biomass & $\begin{array}{l}\text { Greenhouse Microcosm } \\
\text { Long-Term Microcosm }\end{array}$ & $\begin{array}{l}124(80-191) \\
196(151-255)\end{array}$ & $\begin{array}{l}9.5 \% \\
15.1 \%\end{array}$ \\
\hline
\end{tabular}


Table 2.7. Summary of type III sum of squares general linear models assessing the effects of test condition, species and herbicide concentration on percent control biomass for three terrestrial and three wetland target species. Plants were harvested 28 days after spray when grown singly in pots, in greenhouse microcosms and in outdoor microcosms. Terrestrial plants grown in long-term microcosms were harvested 70 days after spray while wetland plants grown in long-term microcosms were harvested 60 days after spray. ( $F=F$ statistic, $\mathrm{df}=$ independent variable and error degrees of freedom, $\mathrm{P}=$ significant at $<0.05)$.

\begin{tabular}{|c|c|c|c|c|}
\hline Model & $\begin{array}{l}\text { Glyphosate } \\
\text { Terrestrial } \\
\text { Tests }\end{array}$ & $\begin{array}{l}\text { Atrazine } \\
\text { Terrestrial } \\
\text { Tests }\end{array}$ & $\begin{array}{l}\text { Glyphosate } \\
\text { Wetland Tests }\end{array}$ & $\begin{array}{l}\text { Atrazine } \\
\text { Wetland Tests }\end{array}$ \\
\hline $\begin{array}{l}\text { Dependent Variable } \\
\text { Transformation }\end{array}$ & $-1 / y+1$ & $\sqrt{y}$ & $-1 / y+1$ & $\sqrt{y}$ \\
\hline Test & $\begin{array}{l}F=4.095 \\
\mathrm{df}=3,342 \\
\mathbf{P}=\mathbf{0 . 0 0 7}\end{array}$ & $\begin{array}{l}F=5.565 \\
d f=3,336 \\
P=\mathbf{0 . 0 0 1}\end{array}$ & $\begin{array}{l}\mathrm{F}=12.024 \\
\mathrm{df}=2,256 \\
\mathrm{P}<\mathbf{0 . 0 0 1}\end{array}$ & $\begin{array}{l}F=13.686 \\
d f=2,260 \\
P<\mathbf{0 . 0 0 0}\end{array}$ \\
\hline Species & $\begin{array}{l}\mathrm{F}=4.950 \\
\mathrm{df}=2,342 \\
\mathbf{P}=\mathbf{0 . 0 0 8}\end{array}$ & $\begin{array}{l}\mathrm{F}=3.935 \\
\mathrm{df}=2,336 \\
\mathbf{P}=\mathbf{0 . 0 2 0}\end{array}$ & $\begin{array}{l}\mathrm{F}=5.612 \\
\mathrm{~d}=2,256 \\
\mathbf{P}=\mathbf{0 . 0 0 4}\end{array}$ & $\begin{array}{l}\mathrm{F}=85.599 \\
\mathrm{df}=2,260 \\
\mathrm{P}<\mathbf{0 . 0 0 1}\end{array}$ \\
\hline Concentration & $\begin{array}{l}\mathrm{F}=549.251 \\
\mathrm{~d}=1,342 \\
\mathrm{P}<\mathbf{0 . 0 0 1}\end{array}$ & $\begin{array}{l}F=184.851 \\
d f=1,336 \\
P<\mathbf{0 . 0 0 1}\end{array}$ & $\begin{array}{l}F=740.175 \\
d \mathbf{f}=1,256 \\
\mathbf{P}<\mathbf{0 . 0 0 1}\end{array}$ & $\begin{array}{l}\mathrm{F}=369.094 \\
\mathrm{df}=1,260 \\
\mathbf{P}<\mathbf{0 . 0 0 1}\end{array}$ \\
\hline Test* Species & $\begin{array}{l}\mathrm{F}=13.626 \\
\mathrm{df}=6,342 \\
\mathrm{P}<\mathbf{0 . 0 0 1}\end{array}$ & $\begin{array}{l}\mathrm{F}=6.850 \\
\mathrm{df}=6,336 \\
P<\mathbf{0 . 0 0 1}\end{array}$ & $\begin{array}{l}\mathrm{F}=12.426 \\
\mathrm{df}=4,256 \\
\mathrm{P}<\mathbf{0 . 0 0 1}\end{array}$ & $\begin{array}{l}\mathrm{F}=10.858 \\
\mathrm{df}=4,260 \\
\mathbf{P}<\mathbf{0 . 0 0 1}\end{array}$ \\
\hline Test* Concentration & $\begin{array}{l}\mathrm{F}=3.471 \\
\mathrm{~d} f=3,342 \\
\mathrm{P}=\mathbf{0 . 0 1 6}\end{array}$ & $\begin{array}{l}\mathrm{F}=5.566 \\
\mathrm{~d} f=3,336 \\
\mathbf{P}=\mathbf{0 . 0 0 1}\end{array}$ & $\begin{array}{l}F=11.556 \\
\mathrm{df}=2,256 \\
\mathbf{P}<\mathbf{0 . 0 0 1}\end{array}$ & N/A \\
\hline $\begin{array}{l}\text { Species* } \\
\text { Concentration }\end{array}$ & $\begin{array}{l}\mathrm{F}=5.552 \\
\mathrm{df}=2,342 \\
\mathrm{P}=\mathbf{0 . 0 0 4}\end{array}$ & $\begin{array}{l}\mathrm{F}=5.327 \\
\mathrm{df}=2,336 \\
\mathbf{P}=\mathbf{0 . 0 0 5}\end{array}$ & $\begin{array}{l}\mathrm{F}=3.551 \\
\mathrm{df}=2,256 \\
\mathbf{P}=\mathbf{0 . 0 3 0}\end{array}$ & N/A \\
\hline $\begin{array}{l}\text { Test* Species * } \\
\text { Concentration }\end{array}$ & N/A & $\begin{array}{l}\mathrm{F}=7.250 \\
\mathrm{df}=6,336 \\
\mathbf{P}<\mathbf{0 . 0 0 1}\end{array}$ & N/A & N/A \\
\hline R-Squared & 0.706 & 0.496 & 0.785 & 0.706 \\
\hline
\end{tabular}


Table 2.8. Summary of the main effects of test condition on percent control biomass for terrestrial and wetland target species sprayed with glyphosate and atrazine. The estimated marginal geometric means are shown with $95 \%$ confidence intervals indicated in brackets. The means were evaluated at the overall average concentration value for each model using Sidak pair-wise comparisons. The lowest mean for each level is indicated in bold. Means followed by the same letter are not statistically different, means followed by a different letter are statistically different.

\begin{tabular}{|c|c|c|c|c|}
\hline Test & $\begin{array}{l}\text { Glyphosate } \\
\text { Terrestrial } \\
\text { Tests }\end{array}$ & $\begin{array}{l}\text { Atrazine } \\
\text { Terrestrial } \\
\text { Tests }\end{array}$ & $\begin{array}{l}\text { Glyphosate } \\
\text { Wetland Tests }\end{array}$ & $\begin{array}{l}\text { Atrazine } \\
\text { Wetland Tests }\end{array}$ \\
\hline Single Species & $\begin{array}{c}0.4273^{\mathrm{a}} \\
(0.3779 \\
0.4803)\end{array}$ & $\begin{array}{c}0.7242^{\mathrm{a}} \\
(0.6140 \\
0.8434)\end{array}$ & $\begin{array}{l}0.2935^{\mathrm{a}} \\
(0.2624- \\
0.3261)\end{array}$ & $\begin{array}{l}0.3137^{\mathrm{a}} \\
(0.2689- \\
0.3619)\end{array}$ \\
\hline $\begin{array}{l}\text { Greenhouse } \\
\text { Microcosm }\end{array}$ & $\begin{array}{l}\mathbf{0 . 2 7 0 0}^{\mathrm{b}} \\
(0.2332- \\
0.3090)\end{array}$ & $\begin{array}{c}\mathbf{0 . 4 4 9 1}^{\mathbf{b}} \\
(0.3893- \\
0.5131)\end{array}$ & $\begin{array}{l}\mathbf{0 . 2 1 2 8}^{\mathrm{b}} \\
(0.1856- \\
0.2413)\end{array}$ & $\begin{array}{c}\mathbf{0 . 2 5 0 6}^{\mathbf{a}} \\
(0.2109- \\
0.2937)\end{array}$ \\
\hline $\begin{array}{l}\text { Long-term } \\
\text { Microcosm }\end{array}$ & $\begin{array}{l}0.3948^{\mathrm{a}} \\
(0.3510- \\
0.4416)\end{array}$ & $\begin{array}{l}0.6929^{\mathrm{a}} \\
(0.6174- \\
0.7727)\end{array}$ & $\begin{array}{l}0.2991^{\mathrm{a}} \\
(0.2679- \\
0.3319)\end{array}$ & $\begin{array}{l}0.4283^{b} \\
(0.3759- \\
0.4841)\end{array}$ \\
\hline $\begin{array}{l}\text { Outdoor } \\
\text { Microcosm }\end{array}$ & $\begin{array}{l}0.4834^{\mathrm{a}} \\
(0.4338- \\
0.5365)\end{array}$ & $\begin{array}{l}0.5661 \\
(0.4981- \\
0.6384)\end{array}$ & & \\
\hline $\begin{array}{l}\text { Concentration } \\
\text { (g ai/ ha) }\end{array}$ & 266 & 228 & 152 & 220 \\
\hline
\end{tabular}


Table 2.9. Summary of type III sum of squares general linear models assessing the effects of test condition, species and herbicide concentration on percent control biomass for nine terrestrial and seven wetland species. Plants were harvested 28 days after spray when grown in greenhouse microcosms and in outdoor microcosms. Terrestrial plants grown in long-term microcosms were harvested 70 days after spray while wetland plants grown in long-term microcosms were harvested 60 days after spray. ( $F=F$ statistic, $\mathrm{df}=$ independent variable and error degrees of freedom, $\mathrm{P}=$ significance at $<\mathbf{0 . 0 5}$ ).

\begin{tabular}{|c|c|c|c|c|}
\hline Model & $\begin{array}{l}\text { Glyphosate } \\
\text { Terrestrial } \\
\text { Tests }\end{array}$ & $\begin{array}{l}\text { Atrazine } \\
\text { Terrestrial } \\
\text { Tests } \\
\end{array}$ & $\begin{array}{l}\text { Glyphosate } \\
\text { Wetland Tests }\end{array}$ & $\begin{array}{l}\text { Atrazine } \\
\text { Wetland Tests }\end{array}$ \\
\hline $\begin{array}{l}\text { Dependent Variable } \\
\text { Transformation }\end{array}$ & $-1 / y+1$ & $-1 / y+1$ & $-1 / y+1$ & $-1 / y+1$ \\
\hline Test & $\begin{array}{l}\mathrm{F}=8.794 \\
\mathrm{df}=2,772 \\
\mathbf{P}<\mathbf{0 . 0 0 1}\end{array}$ & $\begin{array}{l}\mathrm{F}=0.306 \\
\mathrm{df}=2,756 \\
P=0.736\end{array}$ & $\begin{array}{l}\mathrm{F}=24.822 \\
\mathrm{df}=1,399 \\
\mathbf{P}<\mathbf{0 . 0 0 1}\end{array}$ & $\begin{array}{l}\mathrm{F}=3.532 \\
\mathrm{df}=1,392 \\
\mathrm{P}=0.061\end{array}$ \\
\hline Species & $\begin{array}{l}\mathrm{F}=9.715 \\
\mathrm{df}=8,772 \\
\mathbf{P}<\mathbf{0 . 0 0 1}\end{array}$ & $\begin{array}{l}\mathrm{F}=7.752 \\
\mathrm{df}=8,756 \\
\mathrm{P}<\mathbf{0 . 0 0 1}\end{array}$ & $\begin{array}{l}\mathrm{F}=2.990 \\
\mathrm{df}=6,399 \\
\mathbf{P}=\mathbf{0 . 0 0 7}\end{array}$ & $\begin{array}{l}F=1.678 \\
d f=6,392 \\
P=0.125\end{array}$ \\
\hline Concentration & $\begin{array}{l}\mathrm{F}=1141.782 \\
\mathrm{df}=1,772 \\
\mathbf{P}<\mathbf{0 . 0 0 1}\end{array}$ & $\begin{array}{l}\mathrm{F}=313.143 \\
\mathrm{df}=1,756 \\
\mathbf{P}<\mathbf{0 . 0 0 1}\end{array}$ & $\begin{array}{l}\mathrm{F}=659.773 \\
\mathrm{df}=1,399 \\
\mathbf{P}<\mathbf{0 . 0 0 1}\end{array}$ & $\begin{array}{l}F=398.355 \\
\mathrm{df}=1,392 \\
\mathbf{P}<\mathbf{0 . 0 0 1}\end{array}$ \\
\hline Test* Species & $\begin{array}{l}\mathrm{F}=10.622 \\
\mathrm{df}=16,772 \\
\mathbf{P}<\mathbf{0 . 0 0 1}\end{array}$ & $\begin{array}{l}F=1.195 \\
d f=16,756 \\
P=0.266\end{array}$ & $\begin{array}{l}F=5.318 \\
d f=6,399 \\
P<\mathbf{0 . 0 0 1}\end{array}$ & $\begin{array}{l}F=3.429 \\
d f=6,392 \\
P=\mathbf{0 . 0 0 3}\end{array}$ \\
\hline Test* Concentration & $\begin{array}{l}F=7.656 \\
d f=2,772 \\
P=\mathbf{0 . 0 0 1}\end{array}$ & N/A & N/A & N/A \\
\hline $\begin{array}{l}\text { Species* } \\
\text { Concentration }\end{array}$ & $\begin{array}{l}\mathrm{F}=7.467 \\
\mathrm{df}=8,772 \\
\mathbf{P}<\mathbf{0 . 0 0 1}\end{array}$ & $\begin{array}{l}F=13.885 \\
d f=8,756 \\
P<\mathbf{0 . 0 0 1}\end{array}$ & $\begin{array}{l}\mathrm{F}=3.311 \\
\mathrm{df}=6,399 \\
\mathbf{P}=\mathbf{0 . 0 0 3}\end{array}$ & N/A \\
\hline $\begin{array}{l}\text { Test* Species * } \\
\text { Concentration }\end{array}$ & N/A & $\begin{array}{l}\mathrm{F}=1.799 \\
\mathrm{df}=18,756 \\
P=\mathbf{0 . 0 2 2}\end{array}$ & N/A & $\begin{array}{l}F=1.766 \\
d f=13,392 \\
P=\mathbf{0 . 0 4 6}\end{array}$ \\
\hline R-Squared & 0.680 & 0.547 & 0.710 & 0.668 \\
\hline
\end{tabular}




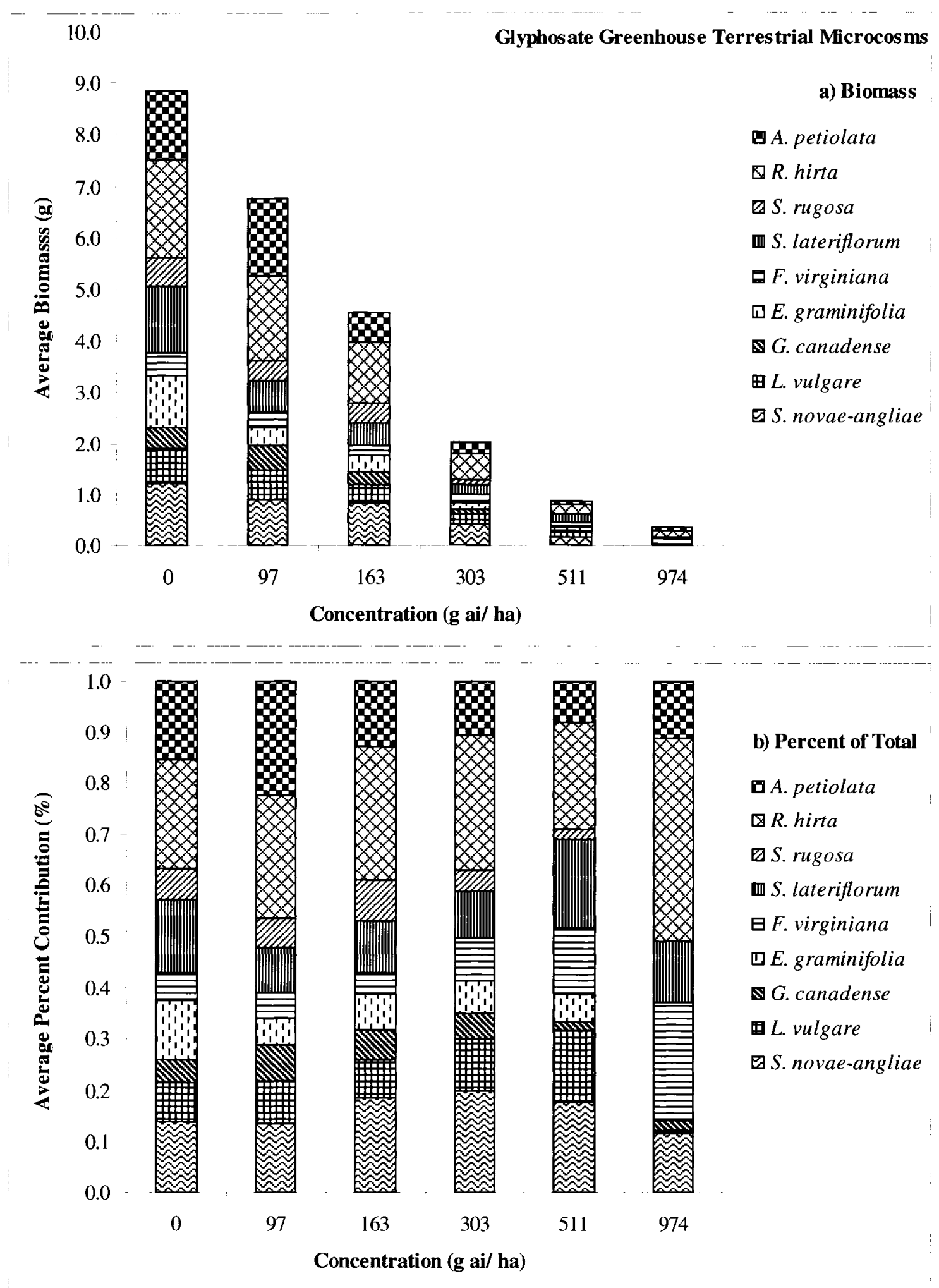

Figure 2.1. Average contribution of each terrestrial species to a) biomass and b) percent of total biomass for greenhouse microcosms sprayed with a range of glyphosate concentrations and harvested 28 days after spray. 
32.0

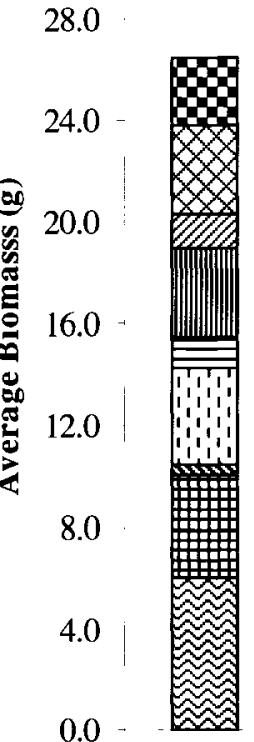

0

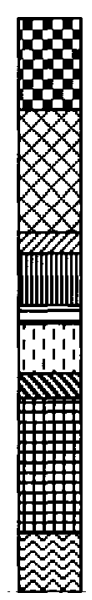

106
Glyphosate Long-Term Terrestrial Microcosms

a) Biomass

$\square$ A. petiolata

$\otimes R$. hirta

U. $S$. rugosa

II S. lateriflorum

日. virginiana

$\square$ E. graminifolia

\$ $G$. canadense

$\boxplus$ T. vulgare

S. novae-angliae

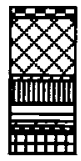

481

621

Concentration (g ai/ ha)

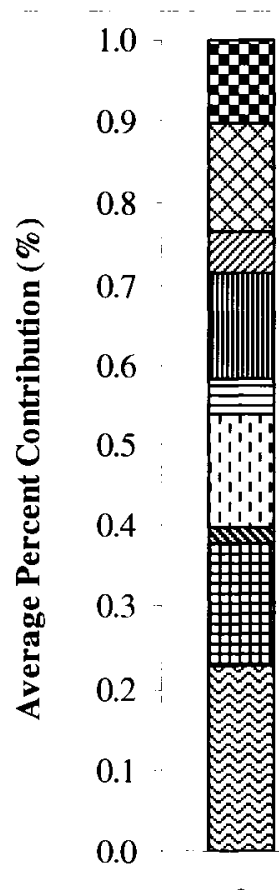

0

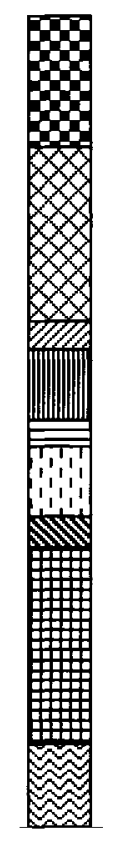

106

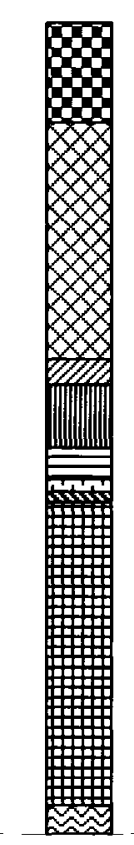

170

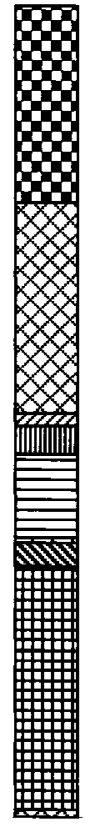

250

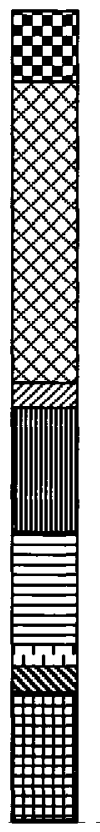

481

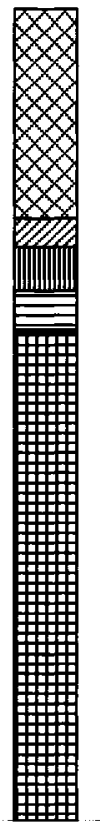

b) Percent of Total

- A. petiolata

Q R. hirta

Ð S. rugosa

四 S. lateriflorum

$\boxminus F$. virginiana

$\square$ E. graminifolia

\$. canadense

田 L. vulgare

$\forall$ S. novae-angliae

Concentration ( $\mathrm{g}$ ai/ ha)

Figure 2.2. Average contribution of each terrestrial species to a) biomass and b) percent of total biomass for long-term microcosms sprayed with a range of glyphosate concentrations and harvested 70 days after spray. 


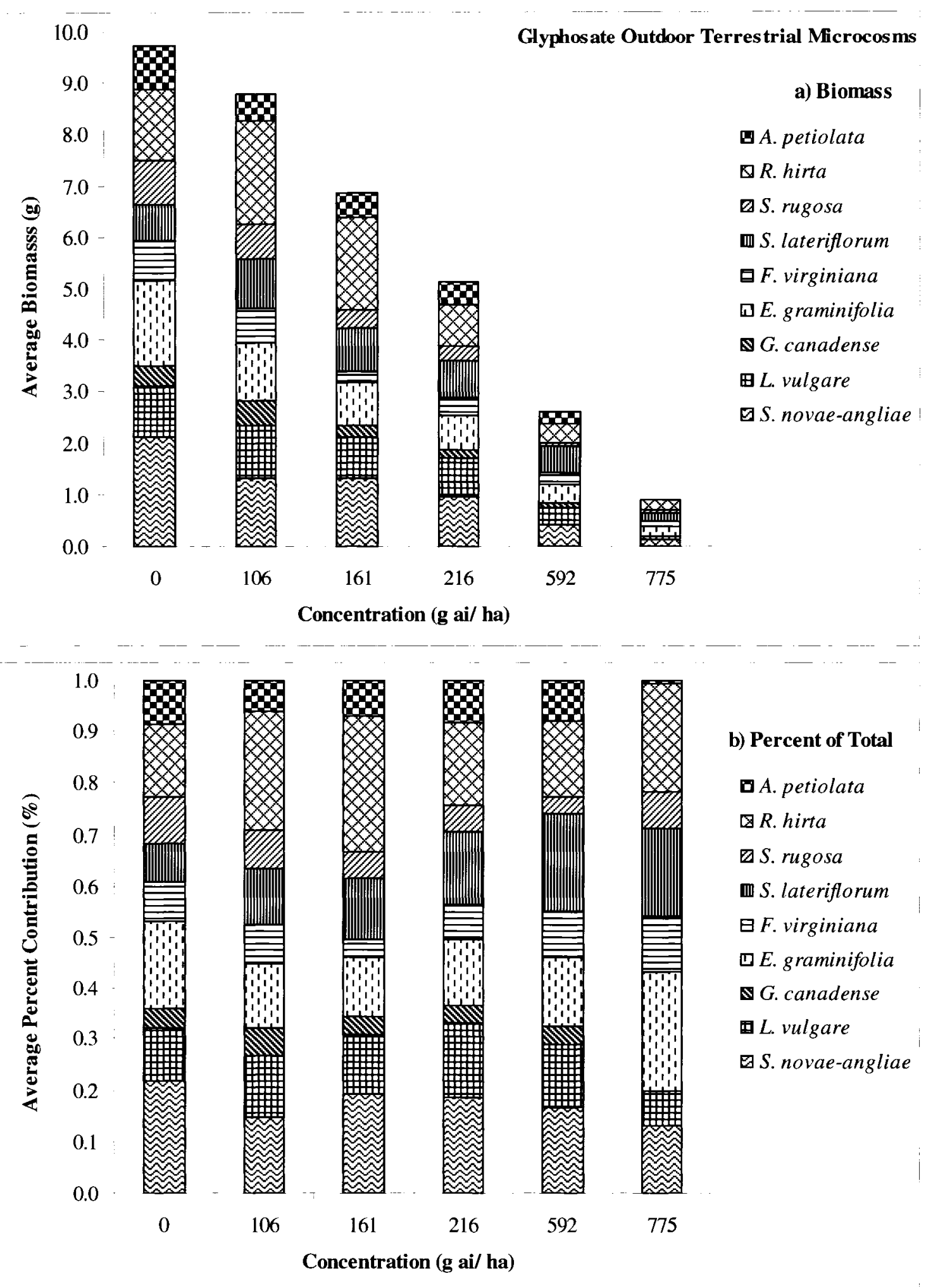

Figure 2.3. Average contribution of each terrestrial species to a) biomass and b) percent of total biomass for outdoor microcosms sprayed with a range of glyphosate concentrations and harvested 28 days after spray. 
18.0

16.0

14.0

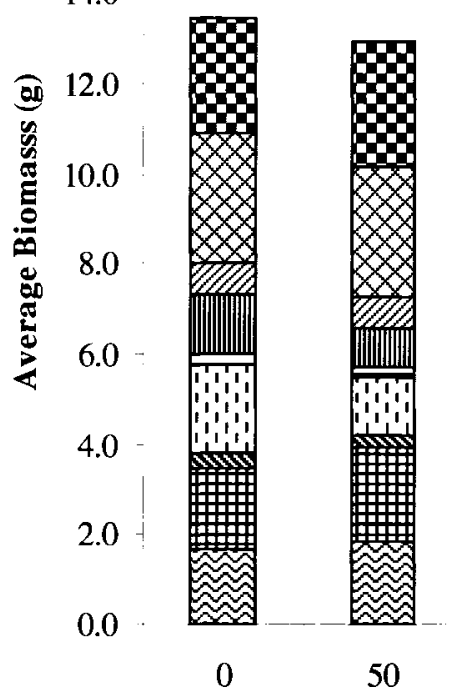

Atrazine Greenhouse Terrestrial Microcosms

a) Biomass

- A. petiolata

曰R. hirta

a $S$. rugosa

[10 S. lateriflorum

日 $F$. virginiana

\ E. graminifolia

G. canadense

田L.vulgare

$\Xi S$. novae-angliae

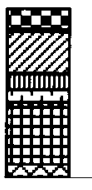

710

Concentration (g ai/ ha)

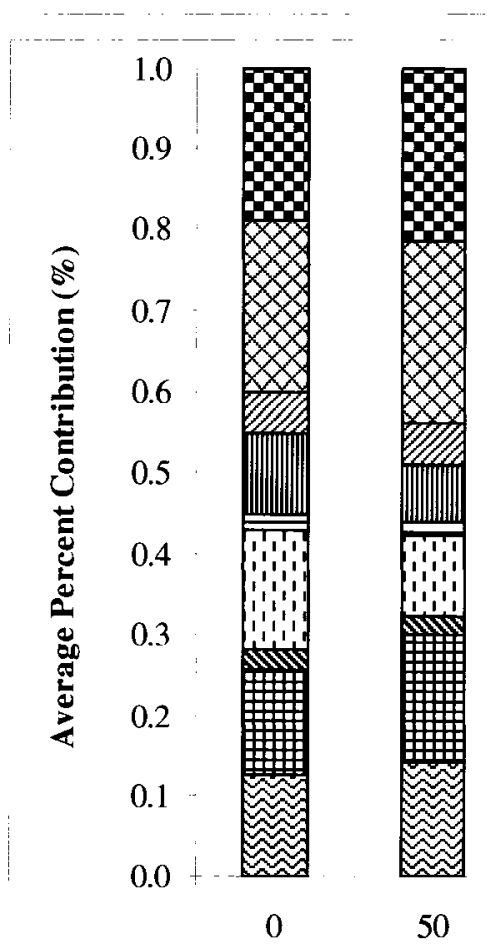

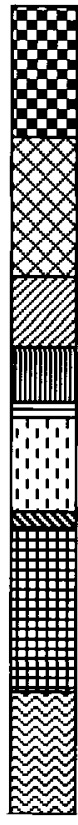

129

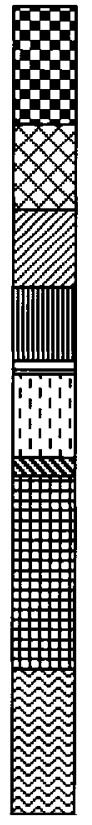

205

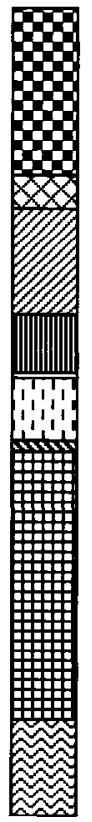

570

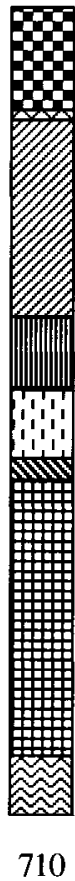

b) Percent of Total

- A. petiolata

Q R. hirta

囚. rugosa

(n) S. lateriflorum

日F. virginiana

$\square$ E. graminifolia

$\mathbf{G}$. canadense

田 L. vulgare

曰S. novae-angliae

Concentration (g ai/ ha)

Figure 2.4. Average contribution of each terrestrial species to a) biomass and b) percent of total biomass for greenhouse microcosms sprayed with a range of atrazine concentrations and harvested 28 days after spray. 


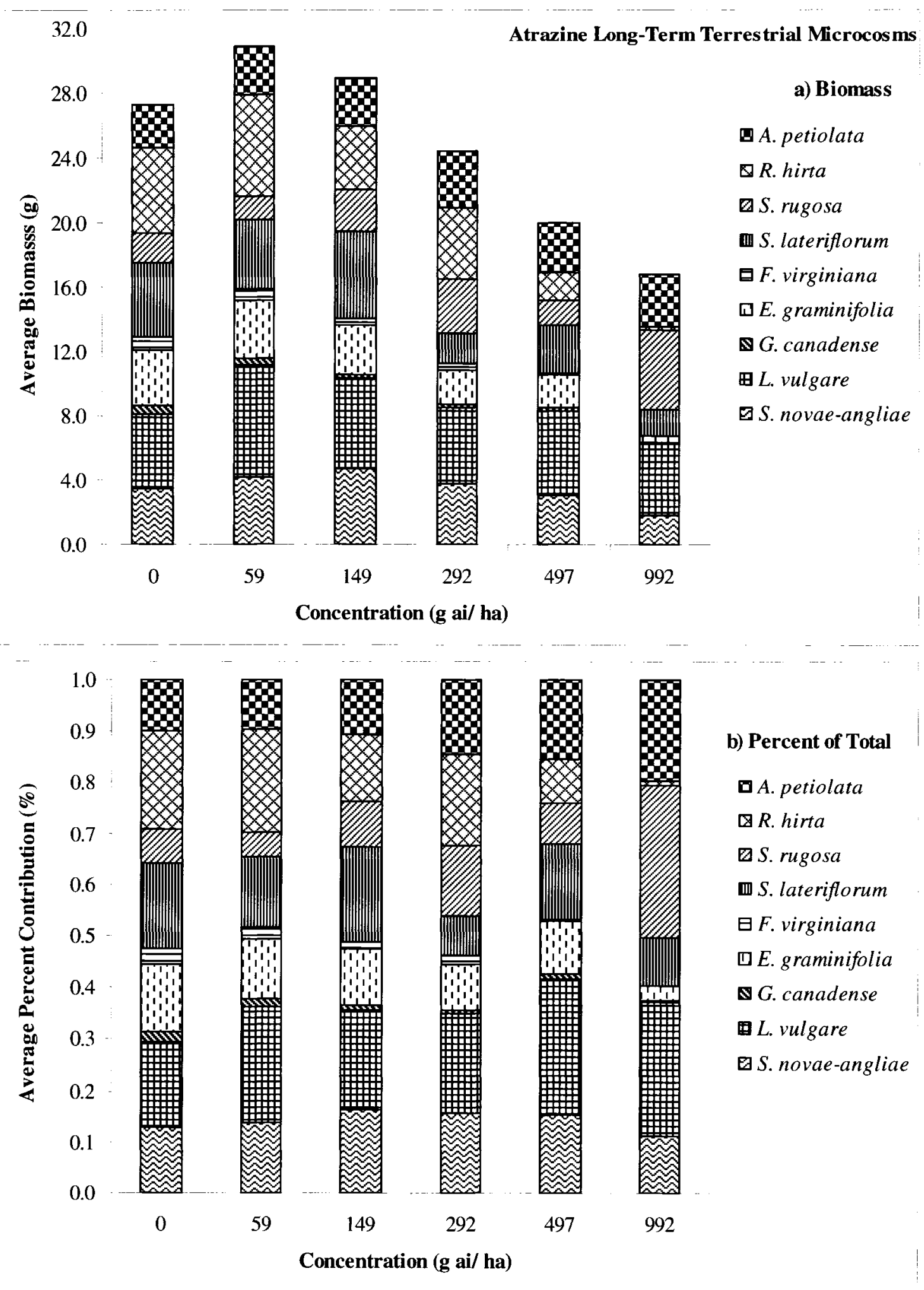

Figure 2.5. Average contribution of each terrestrial species to a) biomass and b) percent of total biomass for long-term microcosms sprayed with a range of atrazine concentrations and harvested 70 days after spray. 


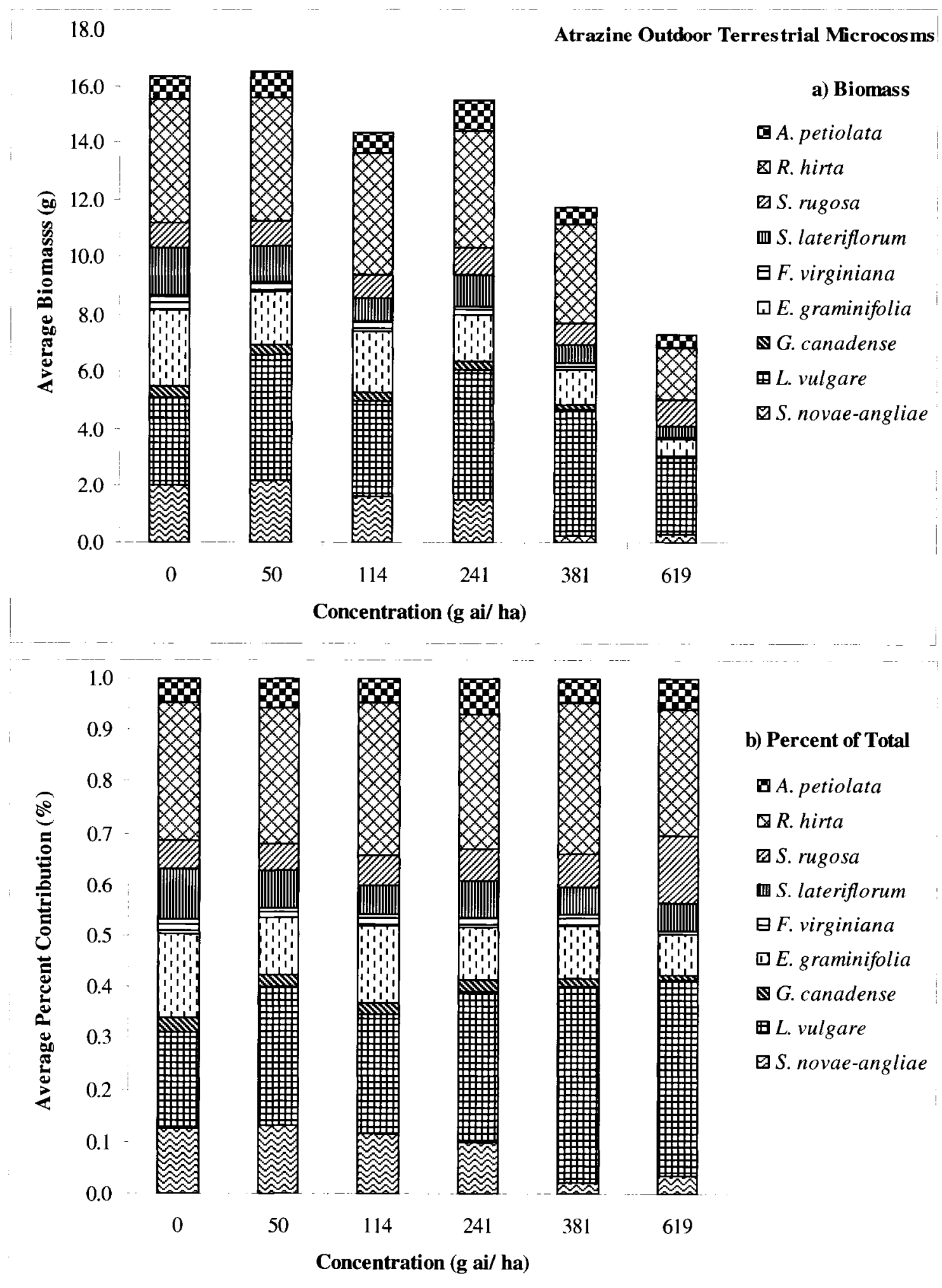

Figure 2.6. Average contribution of each terrestrial species to a) biomass and b) percent of total biomass for outdoor microcosms sprayed with a range of atrazine concentrations and harvested 28 days after spray. 
22.0

20.0

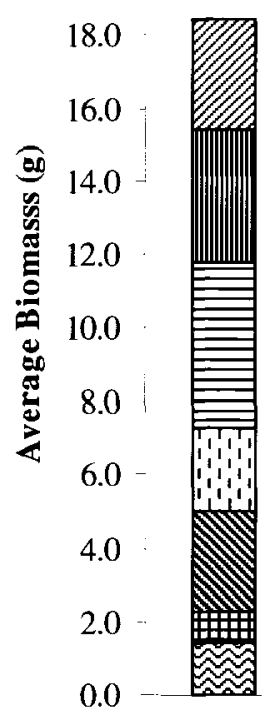

0

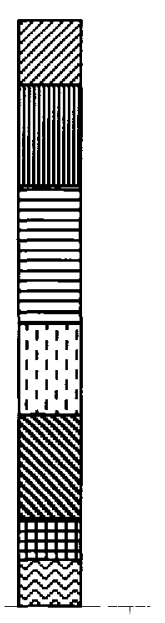

51

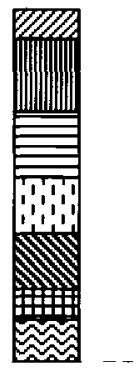

90

Concentration (g ai/ ha)

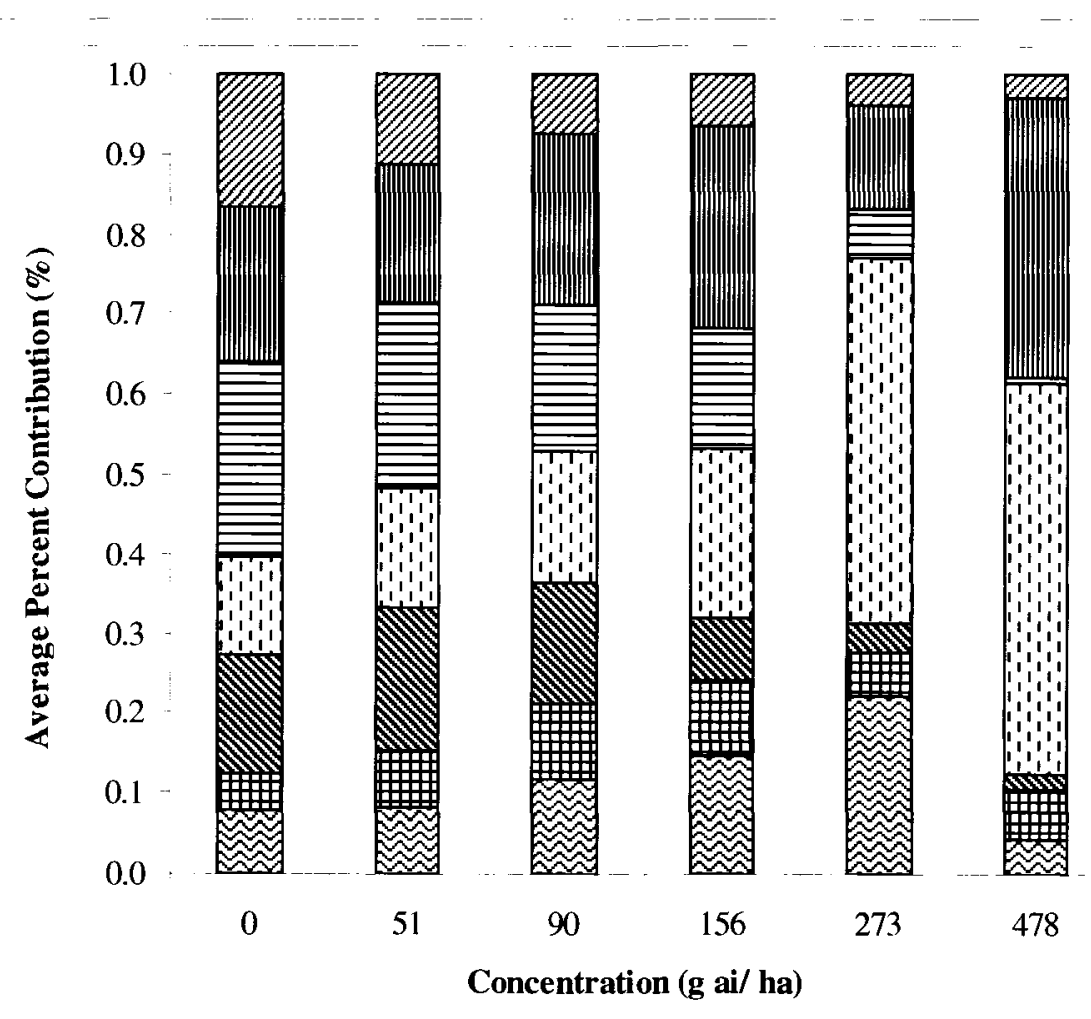

$\checkmark P$ arundinacea

四 E. perfoliatum

$\boxminus$ L. americanus

๑ V. hastata

E. maculatum

田 A. incarnata

๑C. glabra
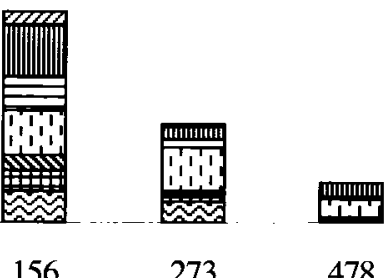

478

a) Biomass 


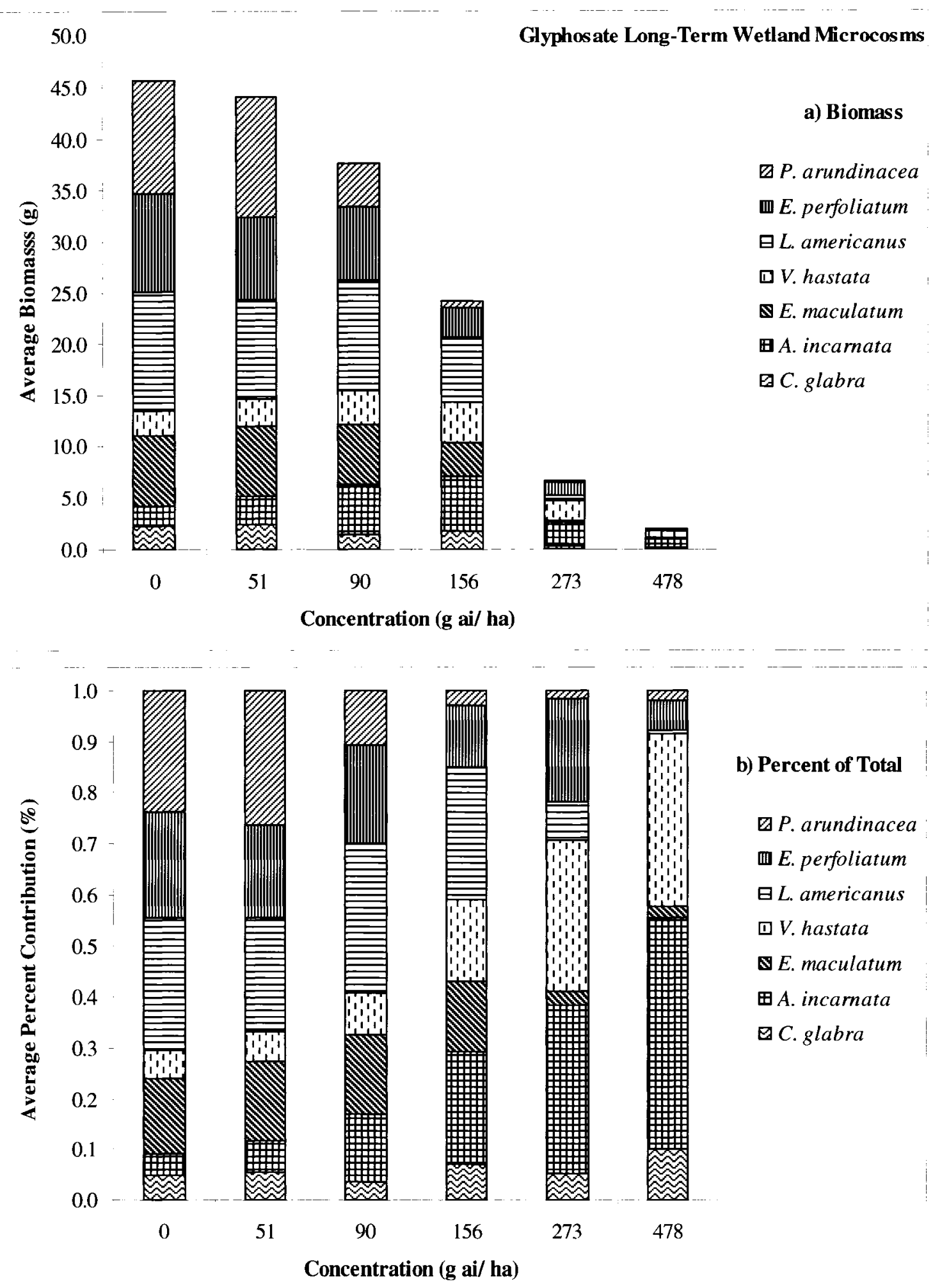

Figure 2.8. Average contribution of each wetland species to a) biomass and b) percent of total biomass for long-term microcosms sprayed with a range of glyphosate concentrations and harvested 60 days after spray. 


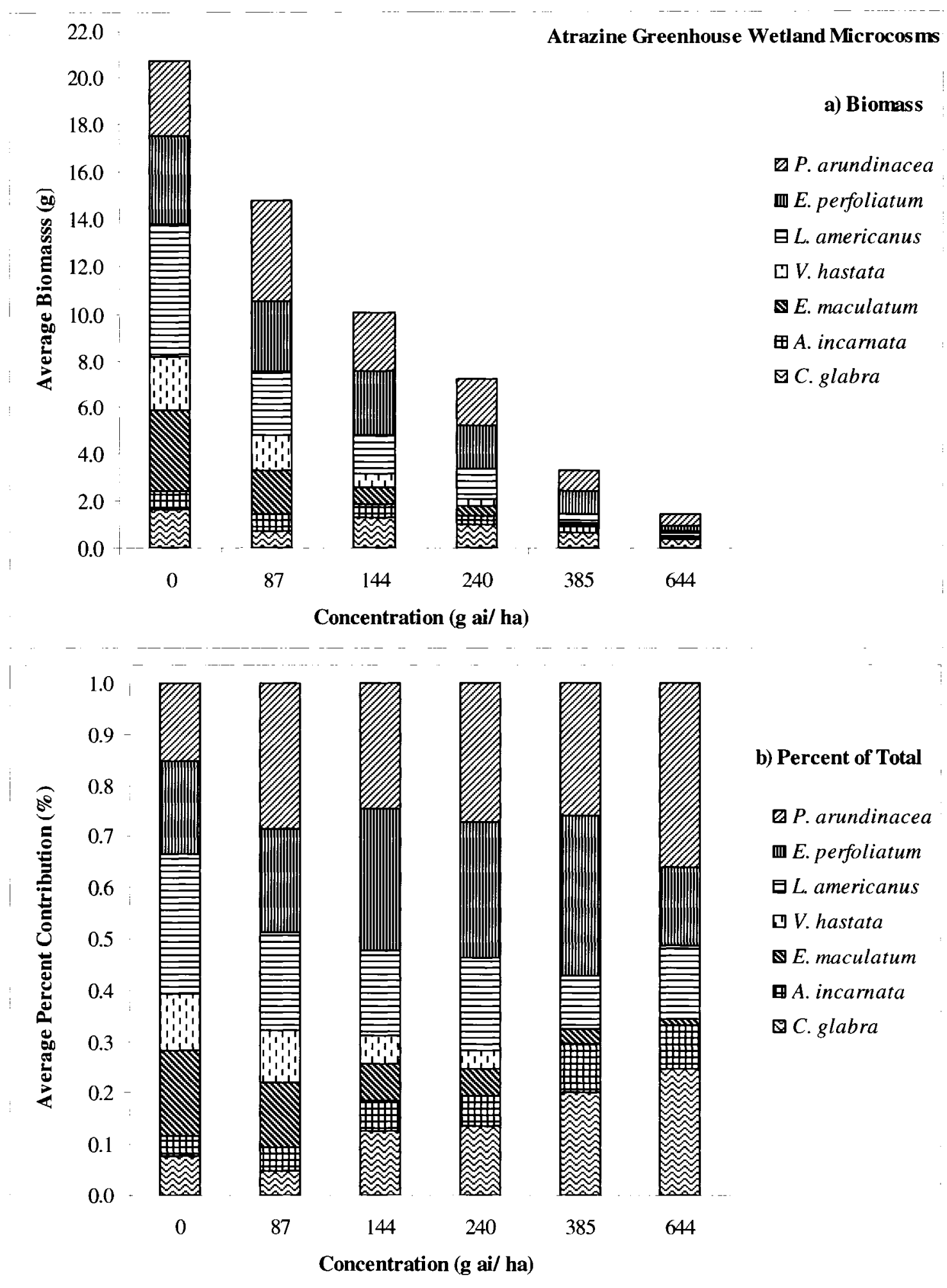

Figure 2.9. Average contribution of each wetland species to a) biomass and b) percent of total biomass for greenhouse microcosms sprayed with a range of atrazine concentrations and harvested 28 days after spray. 


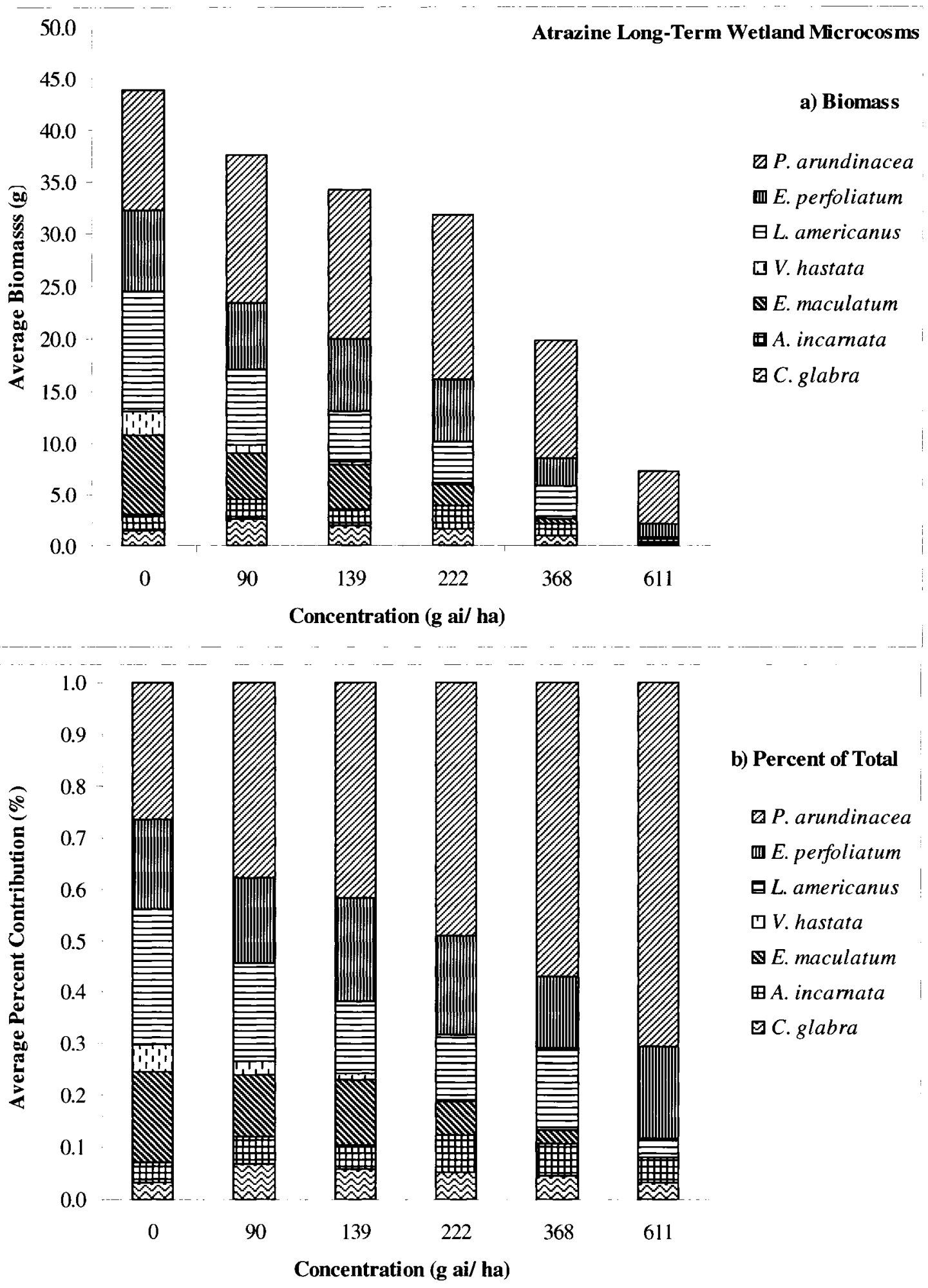

Figure 2.10. Average contribution of each wetland species to a) biomass and b) percent of total biomass for long-term microcosms sprayed with a range of atrazine concentrations and harvested 60 days after spray. 

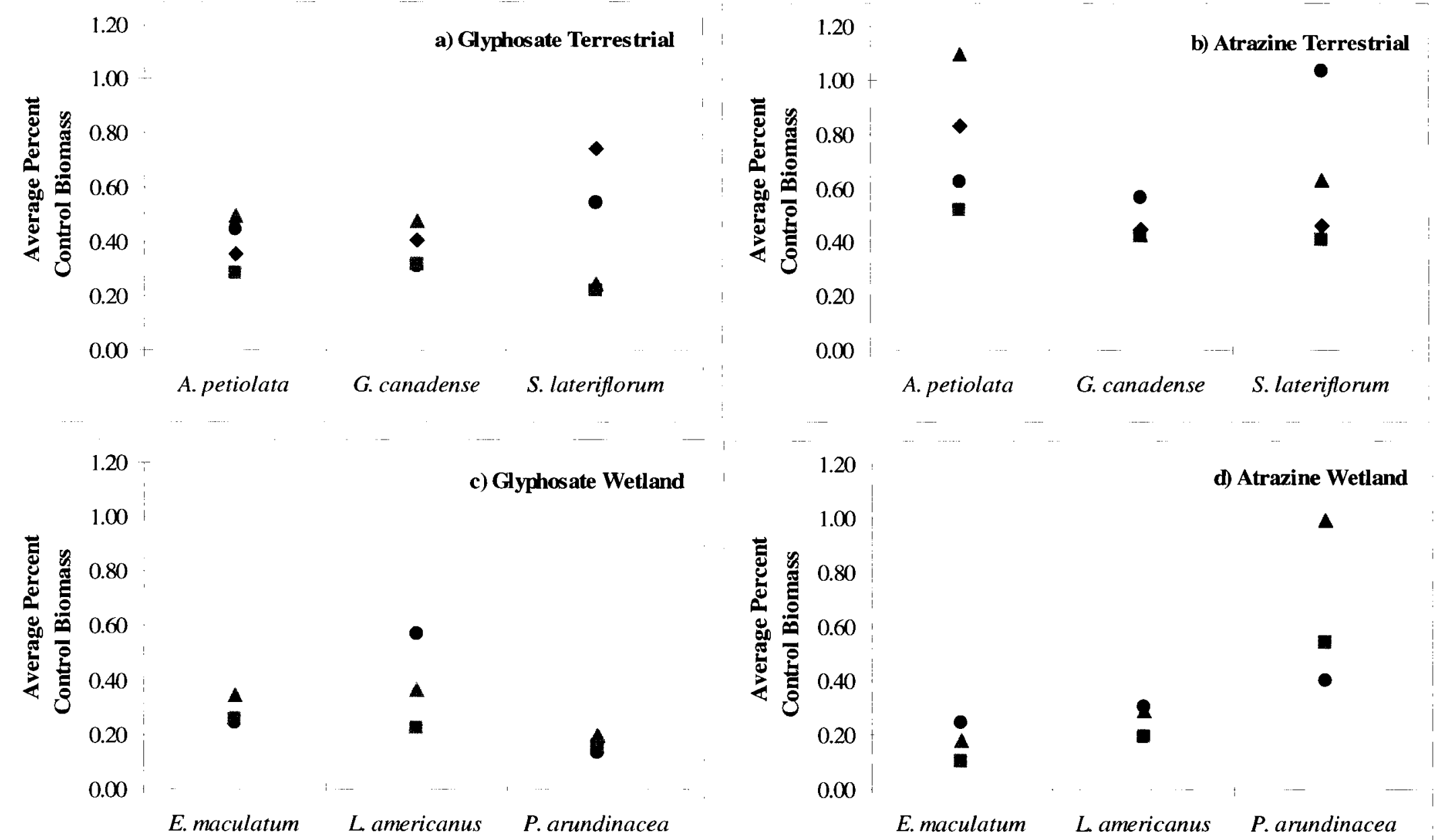

Figure 2.11. Test and species interaction effects on estimated marginal geometric mean percent control biomass at the overall average concentration for each herbicide and habitats type. - $\bullet$ - single species test, $-\mathbf{-}$ - greenhouse microcosm tests, $-\boldsymbol{\Delta}$ - long-term microcosm test, - - outdoor microcosm test. 


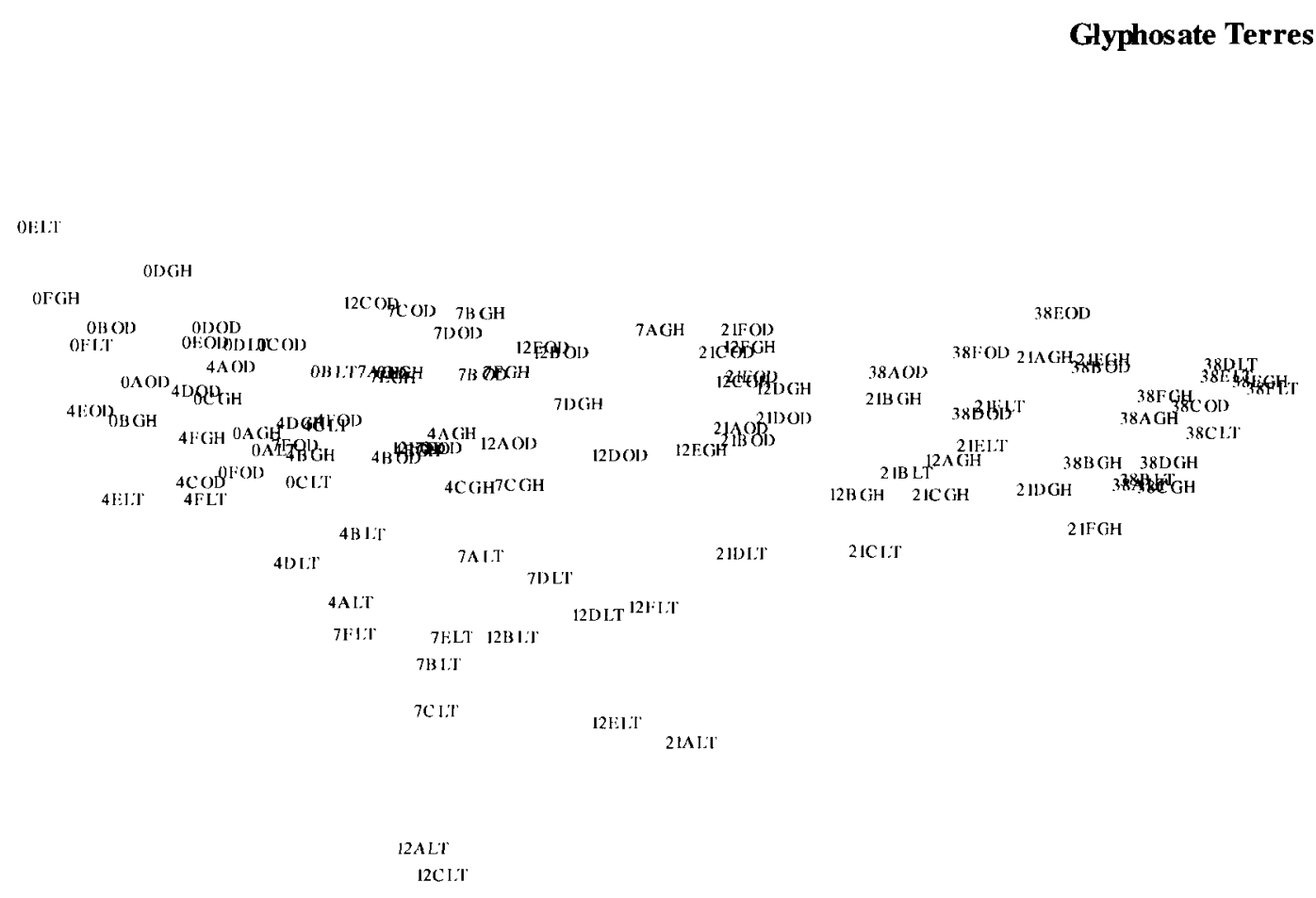

Axis $1(64.8 \%)$

Figure 2.12. Summary of PCA characterizing terrestrial microcosm communities treated with glyphosate based on percent control biomass values calculated for each species. The percent of variation explained by each axis is shown in brackets. The Axis 1 eigenvalue (5.828) was greater than the broken-stick value (2.829) while the Axis 2 eigenvalue (1.020) was less than the broken-stick value (1.829). Numbers 0 to 38 represent percent label rate rounded to the nearest whole number. Letters A-F represent replicates. GH- greenhouse microcosm, LT- long-term microcosm, OD- outdoor microcosm. 


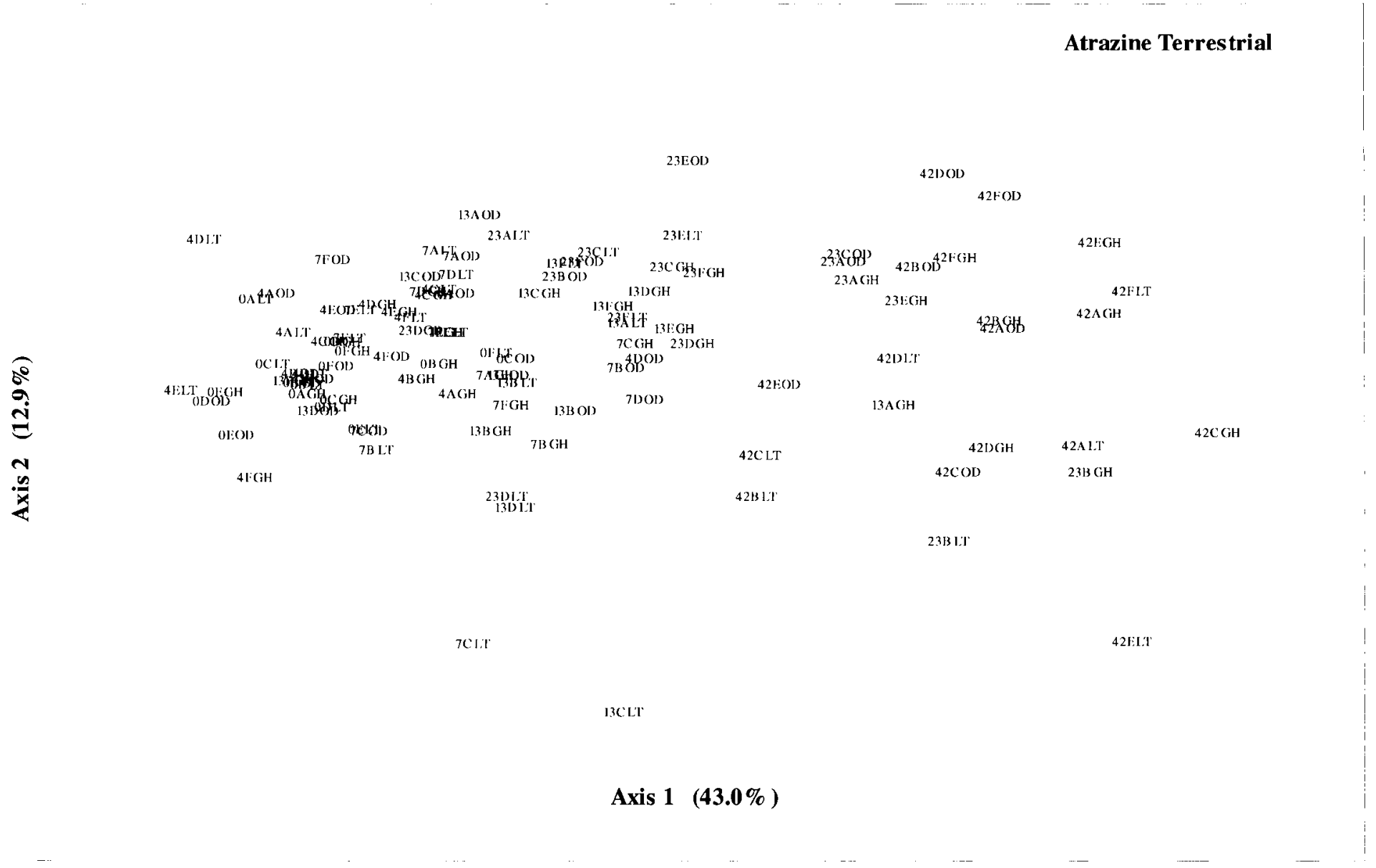

Figure 2.13. Summary of PCA characterizing terrestrial microcosm communities treated with atrazine based on percent control biomass values calculated for each species. The percent of variation explained by each axis is shown in brackets. The Axis 1 eigenvalue (3.870) was greater than the broken-stick value (2.829) while the Axis 2 eigenvalue (1.163) was less than the broken-stick value (1.829). Numbers 0 to 42 represent percent label rate rounded to the nearest whole number. Letters A-F represent replicates. GH- greenhouse microcosm, LT- long-term microcosm, OD- outdoor microcosm. 
Gyphosate Wetland

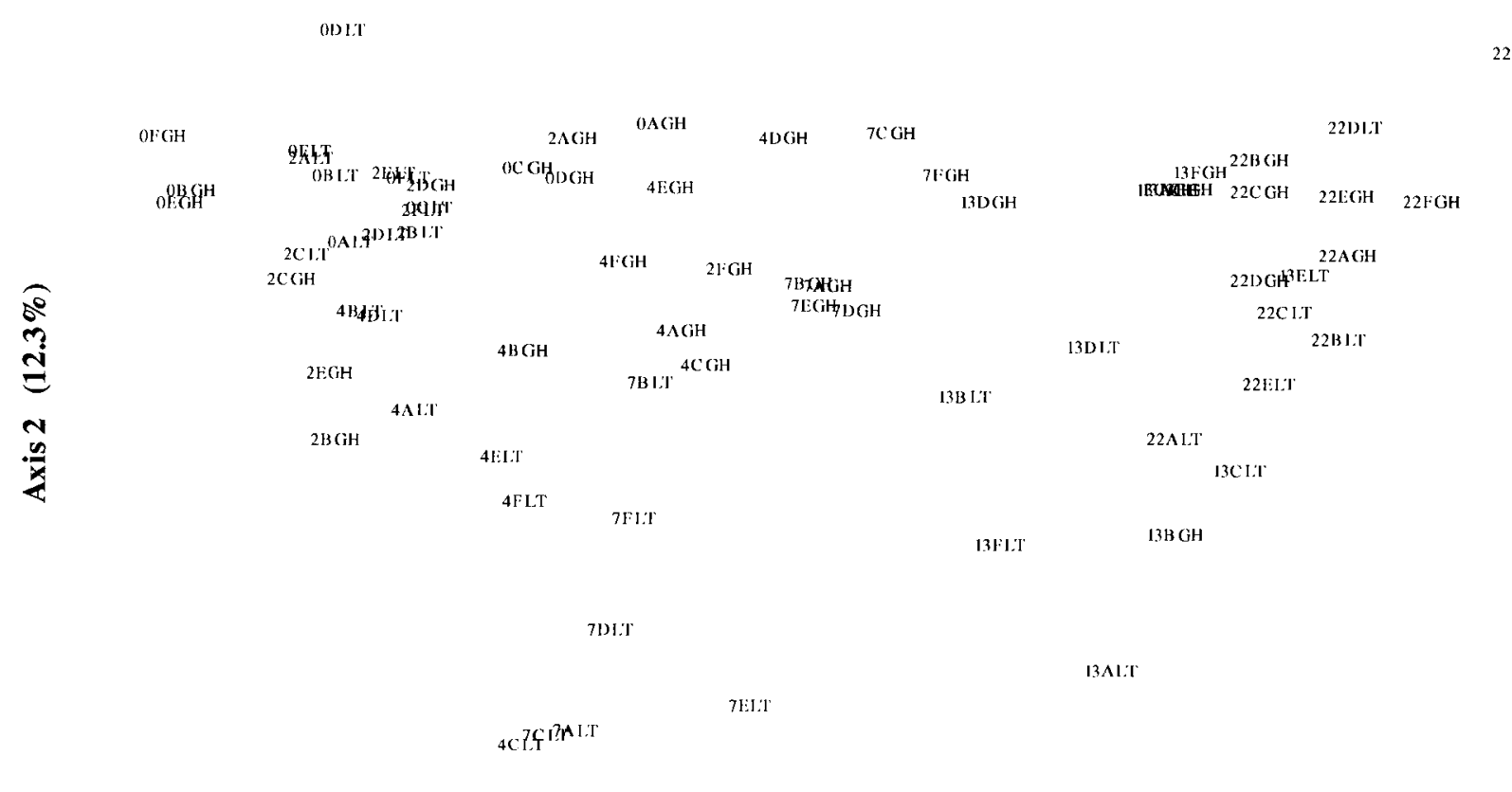

Axis $1 \quad(68.3 \%)$

Figure 2.14. Summary of PCA characterizing wetland microcosm communities treated with glyphosate based on percent control biomass values calculated for each species. The percent of variation explained by each axis is shown in brackets. The Axis 1 eigenvalue (4.781) was greater than the broken-stick value (2.593) while the Axis 2 eigenvalue (0.858) was less than the broken-stick value (1.593). Numbers 0 to 22 represent percent label rate rounded to the nearest whole number. Letters A-F represent replicates. GH- greenhouse microcosm, LT- long-term microcosm. 


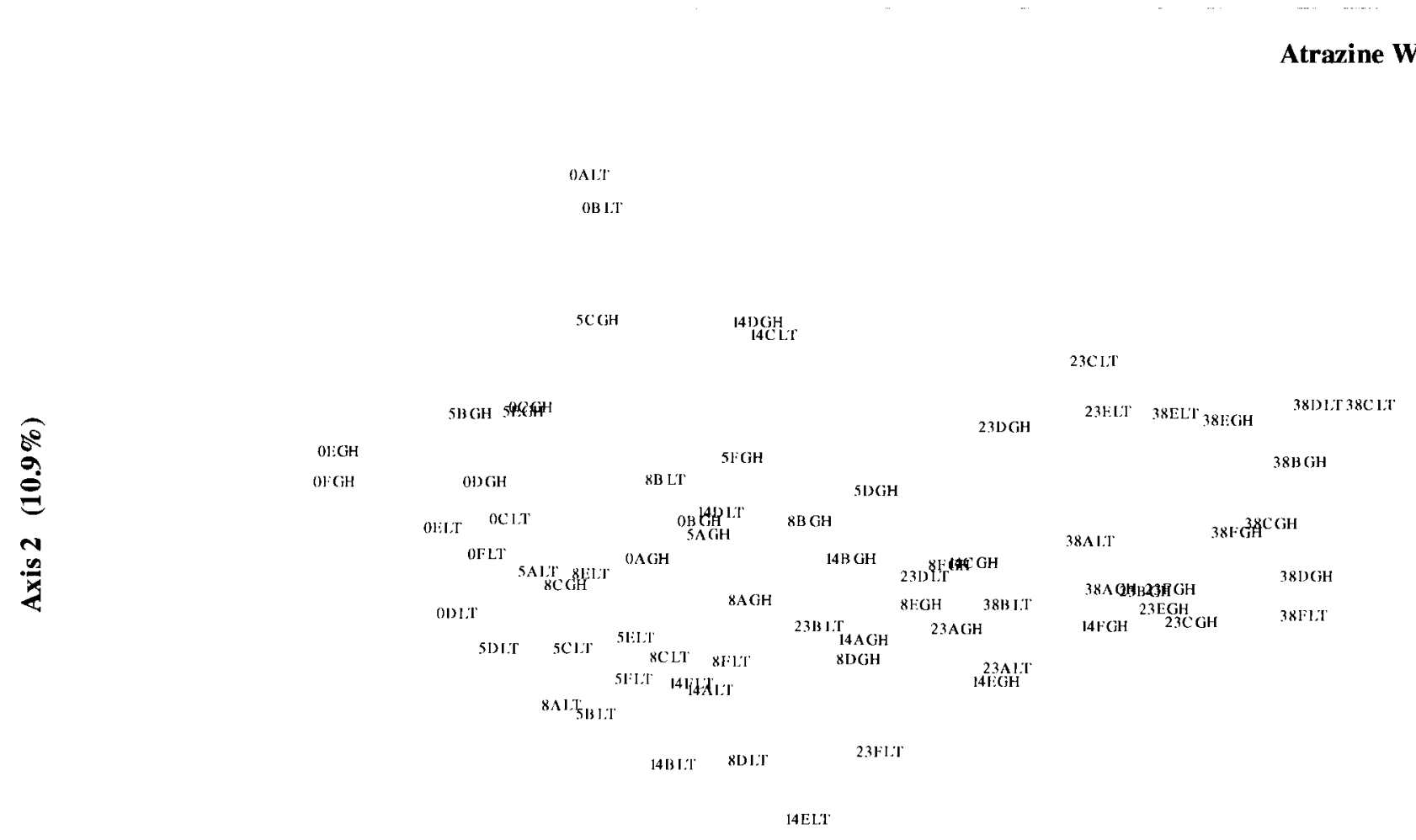

Axis $1(64.1 \%)$

Figure 2.15. Summary of PCA characterizing wetland microcosm communities treated with atrazine based on percent control biomass values calculated for each species. The percent of variation explained by each axis is shown in brackets. The Axis 1 eigenvalue (4.485) was greater than the broken-stick value (2.593) while the Axis 2 eigenvalue (0.765) was less than the broken-stick value (1.593). Numbers 0 to 22 represent percent label rate rounded to the nearest whole number. Letters A-F represent replicates. GHgreenhouse microcosm, LT- long-term microcosm. 


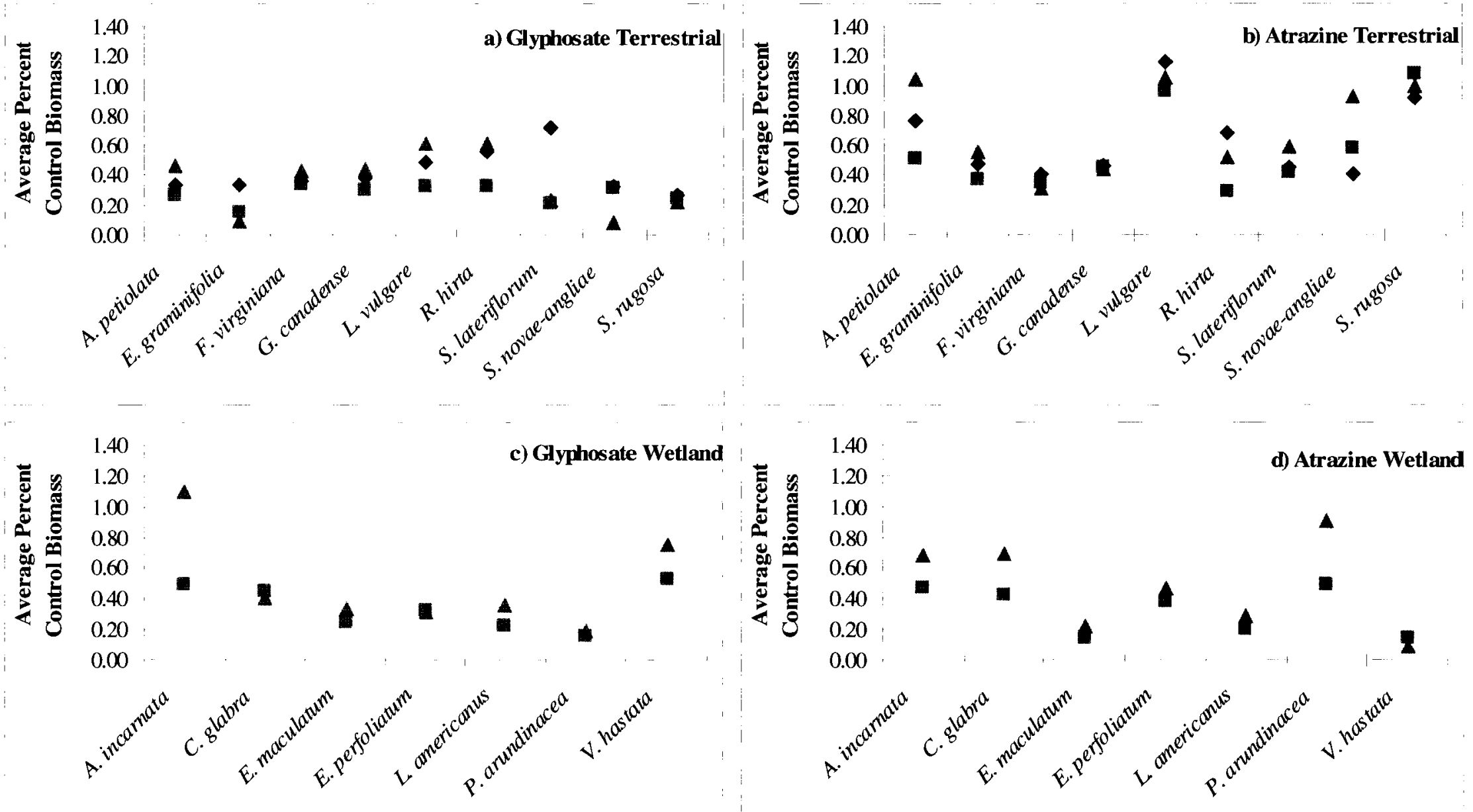

Figure 2.16. Test and species interaction effects on estimated marginal geometric mean percent control biomass at the overall average concentration for nine terrestrial and seven wetland species grown under different microcosm conditions. Species are organized from lowest to highest average mean - $\mathbf{-}$ - greenhouse microcosm tests, - $\mathbf{\Delta}$ - long-term microcosm test, $-\downarrow-$ outdoor microcosm test. 


\section{CHAPTER 3:}

\section{AN EVALUATION OF THE CHLOROPHYLL $A$ FLUORESCENCE PARAMETER FV/FM AS AN INDICATOR OF HERBICIDAL DAMAGE TO NON-TARGET PLANTS EXPOSED TO GLYPHOSATE AND ATRAZINE}

\subsection{INTRODUCTION}

Biomass is the most commonly used endpoint in regulatory phytotoxicity testing (Holst and Ellwanger, 1982; OECD, 1984; EPA, 1996; OECD, 2005). It is an effective and widely accepted endpoint because it is an integrated measure of pesticide damage and is reflective of damage caused by pesticides of differing modes of action. However, biomass has several disadvantages. Subtle long-term effects are difficult to evaluate in a laboratory environment and it is unclear if day 28 biomass measurements provide an accurate assessment of ecological risk. Biomass is a destructive measure and thus cannot always be used for field testing in natural habitats. Ecological risk assessment could be improved by the use of a reliable endpoint that can be used in the field and compared meaningfully to laboratory testing. Chlorophyll $a$ fluorescence is a well-established, nondestructive technique (Krause and Weis, 1984; Krause and Weis, 1991; Govindjee, 1995) which may be a useful additional endpoint in risk assessment for non-target plants.

Chlorophyll fluorescence was first observed and reported by Kautsky and Hirsch in 1931. Its use in a variety of plant studies has increased dramatically since the Pulse Amplitude Modulated (PAM) technique was made widely commercially available in the 1980's by Schreiber, et al. (1986). A number of reviews have focused on the principles behind chlorophyll $a$ fluorescence as well as advances in both theory and technology (e.g. Papageorgiou, 1975; Schreiber, 1983; Krause and Weis, 1984; Lichtenthaler and 
Rinderle, 1988; Krause and Weis, 1991; Govindjee, 1995; Lazár, 1999; Roháček and Barták, 1999; DeEll and Toivonen, (Ed.), 2003).

Chlorophyll molecules are highly effective at absorbing photons of photosynthetically active radiation (PAR) in the $400-700 \mathrm{~nm}$ region of the electromagnetic spectrum (Lichtenthaler and Rinderle, 1988; Harbinson and Rosenqvist, 2003). Once a photon has been absorbed, a chlorophyll molecule will enter a higherenergy excited state and will then fall back to the ground energy state via three main routes of energy dissipation: photochemistry, conversion to heat or re-emission as fluorescence at a wavelength between 690-730 nm (Papageorgiou, 1975; Govindjee, 1995; Roháček and Barták, 1999; Harbinson and Rosenqvist, 2003; Rosenqvist and van Kooten, 2003). The different pathways compete with each other under normal physiological conditions with approximately $80-90 \%$ of the energy used in photosynthesis, 5-15\% dissipated as heat and $0.5-5 \%$ emitted as fluorescence (Papageorgiou, 1975; Lichtenthaler and Rinderle, 1988; Lichtenthaler, 1996). Fluorescence intensity will depend on the wavelength of light absorbed and the fluorescence yield, a function of the probability of fluorescence occurring. Fluorescence yield for photosystem I is small and constant, but yield for photosystem II depends on the physiological state of a plant at de-excitation (Harbinson and Rosenqvist, 2003).

The PAM technique generates a characteristic fluorescence curve known as the Kautsky curve (Figure 3.1). Leaves which have been dark adapted have a $Q_{A}$ (primary quinone) pool that is nearly completely oxidized, meaning that all receptors are ready to receive electrons from excited chlorophyll molecules. In this state, photochemistry efficiency is maximal and non-photochemical quenching is not occurring (Harbinson and 
Rosenqvist, 2003). This condition is referred to as Fo and is independent of photochemical events (Lichtenthaler and Rinderle, 1988). When leaves are illuminated with a bright light, the $\mathrm{Q}_{\mathrm{A}}$ pool is rapidly reduced (Papageorgiou, 1975; Lichtenthaler and Rinderle, 1988; Krause and Weis, 1991; Harbinson and Rosenqvist, 2003; Rosenqvist and van Kooten, 2003). Fluorescence will rise to a maximum, Fm, because metabolism is inactive and non-photochemical quenching has not yet occurred (Krause and Weis, 1991; Harbinson and Rosenqvist, 2003; Rosenqvist and van Kooten, 2003). Subsequent light pulses will result in lower peaks as photochemical and non-photochemical quenching of fluorescence is activated (Harbinson and Rosenqvist, 2003; Rosenqvist and van Kooten, 2003). The parameter $\mathrm{Fv} / \mathrm{Fm}$, where $\mathrm{Fv}=\mathrm{Fm}-\mathrm{Fo}$, can be obtained from this curve and is a measure of the maximum achievable efficiency of photosystem II (Harbinson and Rosenqvist, 2003; Rosenqvist and van Kooten, 2003).

For healthy plants, normal Fv/Fm values range from 0.79 to 0.84 (Rosenqvist and van Kooten, 2003). Under stress conditions, photosynthesis may be reduced without affecting light absorption, resulting in higher rates of dissipation as heat and higher rates of fluorescence (Lichtenthaler and Rinderle, 1988). The direct or indirect inhibition of photosynthesis can be used as an indicator of stress affecting the physiological status of a plant (Krause and Weis, 1984; Lichtenthaler and Rinderle, 1988). Environmental stress is known to cause a faster and steeper rise to $\mathrm{Fm}$ and to also raise Fo, resulting in lower values of Fv/Fm (Krause and Weis, 1984; Krause and Weis, 1991).

The main objective of this portion of the single species and microcosm experiments was to determine if the chlorophyll fluorescence parameter $\mathrm{Fv} / \mathrm{Fm}$ is a useful non-destructive, early indicator of damage caused by the herbicides atrazine and 
glyphosate. A subsequent objective was to determine if Fv/Fm could be used to detect differences in the herbicidal response of plants grown singly in pots with those grown under different microcosm community conditions.

\subsection{MATERIALS AND METHODS}

In addition to biomass measurements, chlorophyll fluorescence measurements were taken during the course of the definitive single species and microcosm test periods. Refer to Chapter 2.2 for a detailed description of species and herbicide selection, growth and spray conditions as well as the experimental design of the definitive and microcosm tests.

Whole-plant chlorophyll fluorescence measurements were taken for two terrestrial (G. canadense and S. lateriflorum) and two wetland (E. maculatum and L. americanus) target species. For the terrestrial species, measurements were taken on plants grown singly in pots, in greenhouse microcosms and in long-term microcosms on days $7,14,21$ and 28 following spray. Plants grown in outdoor microcosms were measured on day 28 only, due to the difficulty in moving the microcosms from the outdoor field compound to the fluorescence machine. Measurements were taken on days 7, 14, 21 and 28 for wetland definitive tests but only on day 7 and 14 for wetland greenhouse and long-term microcosms. Measurements were not taken on days 21 or 28 for these tests or past day 28 for any test due to the large size of the plants. In addition, previous research by White (2006) had found that recovery of chlorophyll fluorescence often occurs. In all cases, chlorophyll fluorescence was measured for three replicates of each herbicide concentration and control. It should be noted that because plants for both greenhouse and 
long-term microcosm tests were grown in the greenhouse and sprayed with the same nominal concentrations, these two tests types should be replicates of each other on the days measured.

Prior to measurements of chlorophyll fluorescence, plants were dark adapted for a minimum of 30 minutes. All measurements were taken during mid-afternoon or earlyevening. Chlorophyll fluorescence was measured using a kinetic fluorescence CCD camera (Photon Systems Instruments, Czech Republic). Measuring flashes were approximately $0.03 \mu \mathrm{mol} \mathrm{m} \mathrm{m}^{-2} \mathrm{~s}^{-1}$ in intensity and $10 \mathrm{~ms}$ in duration. Saturating light pulses, generated from a $250 \mathrm{~W}$ halogen bulb were $1.6 \mathrm{~s}$ in duration at an intensity of $2000 \mu \mathrm{mol} \mathrm{m} \mathrm{s}^{-2}$. Actinic light, generated from two LED panels was $60 \mathrm{~s}$ in duration at an intensity of $175 \mu \mathrm{mol} \mathrm{m} \mathrm{m}^{-2} \mathrm{~s}^{-1}$ and had a maximum wavelength of $620 \mathrm{~nm}$. In the microcosm pots, chlorophyll fluorescence of the target species was isolated by covering the other species with black plastic.

The chlorophyll fluorescence parameter Fv/Fm was used in analysis. Data were converted to percent of control Fv/Fm values so that herbicide concentration could be used as a log-linear covariate. The doses selected for each test were approximately loglinear when in the form $\log g$ ai/ha but were not log-linear when the control was included.

Each test for both herbicides and habitat types was analyzed separately to determine if the number of days after spray, species or herbicide concentration affected percent control Fv/Fm. Day and species were included in the analyses as independent fixed categorical predictor variables while herbicide concentration was treated as a loglinear covariate. The analysis of covariance (ANCOVA) assumption of homogeneity of slopes was assessed for each model. If the assumption was met, a type III sum of squares 
ANCOVA was conducted. In cases where the assumption was not met (i.e. there was an interaction between one or more predictor variables and the covariate), the interaction term(s) was included in the model. For each model, the general linear model assumption of normality of residuals and homogeneity of variance was assessed using a ShapiroWilk's test and Levene's test as well as through a visual assessment of the residuals. The dependent variable was transformed to best meet the assumptions using a square, cube or fourth power transformation.

Day 7 measurements were chosen to compare percent control Fv/Fm between single species and microcosm tests. For the terrestrial tests, day 28 was also examined because fluorescence measurements were only available for the outdoor microcosms on this day. General linear models were constructed and assessed similarly to the analyses described above. Concentration ( $\log \mathrm{g}$ ai/ ha) was a covariate, while test condition (single species, greenhouse, outdoor or long-term) and species were independent fixed categorical predictors of percent control Fv/Fm. A separate model was constructed for each herbicide and habitat combination. The differences between the main effects of test and species were assessed by calculating the estimated marginal geometric mean for each level of the variables and performing Sidak pair-wise comparisons. Means were calculated at the overall average measured concentration for a given herbicide-habitat combination to be able to compare between tests.

The relationship between percent control biomass and percent control Fv/Fm was assessed using a nonparametric bivariate correlation for each herbicide and habitat type. 


\subsection{RESULTS}

There was a clear negative relationship between percent control Fv/Fm and herbicide concentration, particularly at the highest herbicide doses (Figures 3.2-3.11). For all tests of both herbicides and habitat types, concentration had a significant effect on percent control Fv/Fm (Tables 3.1 and 3.2). In comparison to day, species and interaction variables, concentration had a large effect as indicated by the large F-statistics (Tables 3.1 and 3.2).

For all terrestrial tests and half of the wetland tests, species had a significant effect on percent control Fv/Fm (Tables 3.1 and 3.2). This is best highlighted in Figure 3.4 where Fv/Fm is markedly different on day 28 for G. canadense and S. lateriflorum grown in outdoor microcosms treated with glyphosate. Differences were greatest at the highest herbicide dose for this test. Fv/Fm was reduced completely for G. canadense but by only $4.6 \%$ (compared to the control) for S. lateriflorum.

There was no consistent effect of day for the tests conducted (Tables 3.1 and 3.2). In fact, there was no consistent model which explained the variation in percent control Fv/Fm for all tests (Tables 3.1 and 3.2). The exact combination of the variables that explained percent control Fv/Fm differed depending on the habitat, herbicide and test condition.

Day 7 percent control Fv/Fm values, along with terrestrial day 28 percent control Fv/Fm values were chosen to examine the effects of test condition, species and concentration on Fv/Fm. Again it can be observed that no single model explained the variation in Fv/Fm under all conditions (Table 3.3 and 3.4). Concentration consistently had the greatest effect on percent control Fv/Fm values, with F-statistics far greater than 
those for test, species or interaction variables. The strength of the relationship between percent control Fv/Fm and concentration indicated that Fv/Fm can be used as an endpoint to assess herbicidal damage. The average reduction in Fv/Fm compared to the control was examined for all tests at the highest and middle concentration. At the highest doses tested, Fv/Fm was reduced by 4.6 to $100 \%$ with an average reduction of $41 \%$, whereas Fv/Fm was reduced by 0.2 to $28.5 \%$ with an average of $8.5 \%$ at the middle concentration (Figures 3.2-3.11).

There was a significant difference between test conditions for each model except for wetland tests treated with glyphosate (Tables 3.3 and 3.4). The lack of statistical difference between tests for wetland species treated with glyphosate may be related to the use of nominal concentrations in the statistical analysis for this model. In each case, the estimated marginal geometric means for the greenhouse microcosm tests were lower than the means for any other test (Table 3.5). Means for long-term microcosm tests were generally similar to the means for the greenhouse microcosms. In the terrestrial tests, Fv/Fm was higher in outdoor microcosms on day 28 compared to Fv/Fm values for microcosms grown in the greenhouse. Single species tests consistently had the highest mean Fv/Fm (i.e. smallest overall decrease) (Table 3.5). The overall reduction in Fv/Fm at the average concentration was quite small ranging from only 0.0005 to $23.6 \%$.

A significant effect of species was observed for half of the models, while a significant interaction between species and concentration was found in two-thirds of the models (Tables 3.3 and 3.4). Depending on the specific species and herbicides tested Fv/Fm may differ, either as a result of inherent differences in Fv/Fm between species or due to different herbicide sensitivities. A significant interaction between test and species 
was observed only for atrazine terrestrial tests on day 7 and on day 28 (Tables 3.3 and 3.4).

The $\mathrm{R}^{2}$ values for each habitat and herbicide combination were quite high when day 7 percent control Fv/Fm values were used, indicating that the models explain the majority of the variation in Fv/Fm (Table 3.3). When day $28 \mathrm{Fv} / \mathrm{Fm}$ values were used, the $\mathrm{R}^{2}$ value remained high for the terrestrial tests treated with atrazine but dropped for the terrestrial tests treated with glyphosate. Percent control Fv/Fm may be an effective endpoint for atrazine throughout the test period, but appeared to be best for glyphosate early in the test period.

Nonparametric bivariate correlations were conducted to relate day $7 \mathrm{Fv} / \mathrm{Fm}$ with biomass. A Spearman's rho value of 0 indicates that there is no relationship whereas values of -1 and +1 indicate a perfect negative and positive relationship respectively. For each herbicide and habitat type, there was a significant positive correlation between percent control biomass and percent control Fv/Fm (Table 3.6). The correlation between day $7 \mathrm{Fv} / \mathrm{Fm}$ and biomass is quite strong, particularly for the wetland tests and for plants treated with atrazine. The correlation between Fv/Fm and biomass was weaker when day $28 \mathrm{Fv} / \mathrm{Fm}$ values were used (Table 3.6). The correlation was generally weaker when day 60 or 70 biomass values were used, suggesting that some recovery of biomass occurred (Table 3.6).

\subsection{DISCUSSION}

De-excitation of chlorophyll molecules via photochemistry, heat dissipation or chlorophyll fluorescence occur at specific rates which are reflected in fluorescence 
intensity (Harbinson and Rosenqvist, 2003). Under stress conditions, photosynthesis may be reduced without light absorption being affected, resulting in higher dissipation as heat and higher rates of fluorescence (Lichtenthaler and Rinderle, 1988). Therefore, the direct or indirect inhibition of photosynthesis can be used as an indicator of stress affecting the physiological status of a plant (Krause and Weis, 1984; Lichtenthaler and Rinderle, 1988). The parameter Fv/Fm is the maximum achievable efficiency of photosystem II and is a measure of its intactness and physiological state (Krause and Weis, 1991; Harbinson and Rosenqvist, 2003; Rosenqvist and van Kooten, 2003). Environmental stresses that affect photosystem II efficiency lead to a decrease in Fv/Fm (Krause and Weis, 1984).

The results of this component of the study clearly demonstrated that the chlorophyll $a$ fluorescence parameter, Fv/Fm, is negatively affected by commercial formulations of the herbicides glyphosate and atrazine. Not all pesticides affect Fv/Fm. A study by Xia, et al. (2006) found that while Fv/Fm was undetectable in cucumber plants exposed to paraquat, eight other pesticides had no effect on Fv/Fm. Similarly, Krugh and Miles (1996) found that while diuron resulted in decreased Fv/Fm values, only small changes were observed for several other pesticides.

Atrazine is a photosystem II inhibitor (Tomlin, 2000) so it is not surprising that atrazine had a negative effect on Fv/Fm. The effect of photosystem II inhibitors on fluorescence has been well studied. Photosystem II inhibitors generally block electron transfer from $\mathrm{Q}_{\mathrm{A}}$ to $\mathrm{Q}_{\mathrm{B}}$ by binding to the $\mathrm{Q}_{\mathrm{B}}$ receptor site (Bowyer, et al., 1991; Krause and Weis, 1991). Fo will be higher and Fv lower in the presence of photosystem II inhibitors leading to lower values of Fv/Fm (Krause and Weis, 1984; Krause and Weis, 
1991). Several studies have shown reductions in Fv/Fm similar to those observed in this study (Zheleva, et al., 1994; Ralph, 2000; Barbagallo, et al., 2003).

The response of $\mathrm{Fv} / \mathrm{Fm}$ in glyphosate treated plants is more surprising because glyphosate is an inhibitor of EPSP and not of photosystem II directly (Tomlin, 2000). A study by Ralph (2000) found that glyphosate had no effect on chlorophyll $a$ fluorescence of sea grass even though it was applied at concentrations two orders of magnitude higher than concentrations of atrazine and diuron that resulted in significant negative effects. However, several other studies have found that glyphosate decreased Fv/Fm values (Barbagallo, et al., 2003; Christensen, et al., 2003; White, 2006). Glyphosate can effectively reduce photosynthesis within minutes of application (Geiger, et al., 1999). It has been found to decrease chlorophyll synthesis, pigment content and decrease photosystem I and II activity, suggesting that it may have photosynthetic electron transport inhibition properties (Hernando, et al., 1989). The results of this study suggest the indirect inhibition of photosystem II by glyphosate reduced Fv/Fm in a dose-response pattern.

Under the majority of the test conditions, differences in Fv/Fm existed between species or there was an interaction between species and concentration. Since only two species of each habitat type (terrestrial or wetland) were examined, it is not surprising that no obvious trend emerged in the sensitivity of species belonging to a particular habitat type. Fv/Fm values have been shown to be remarkably similar between species when not under stress. A study examining Fv/Fm values for 44 species of vascular plants representing diverse taxa, habitats, life forms and growth conditions found that the mean value of $\mathrm{Fv} / \mathrm{Fm}$ was 0.832 with a standard deviation of only \pm 0.004 (Björkman and 
Demmig, 1987). Differences in fluorescence parameters between species are more variable when plants are under chemical stress. Snel, et al. (1998) found that there were no significant differences in $\mathrm{EC}_{50} \mathrm{~s}$ (50\% effective concentrations) for six different macrophytes exposed to linuron while Franzaring, et al. (2001) found that a reduction in fluorescence was observed in some species exposed to chlorpropham and ethofumesate while not in others. A study by Korres, et al. (2003) found that Fv/Fm was an effective parameter for detecting differences between wheat cultivars, demonstrating that this parameter is quite sensitive in some situations.

In addition to differences between species, there were differences between test conditions. There were significant differences for each habitat-herbicide combination with the exception of wetland species treated with glyphosate and measured on day 7. This may have been related to decreased sensitivity in the model because the effect of concentration may not have been accurately described using nominal concentration data. In each case, Fv/Fm values were more affected in greenhouse microcosm tests while single species tests were the least affected.

To my knowledge, no other study has specifically set out to examine the response of Fv/Fm under single and multi-species test conditions other than Snel, et al. (1998). In this study, the authors found that the $\mathrm{EC}_{50}$ was higher in a single species test than in an aquatic microcosm test, although the result was not statistically significant and only one species was examined (Snel, et al., 1998). Results of the present study suggest that species are more sensitive to glyphosate and atrazine when grown in a community versus when they are grown singly in pots but the overall size of the effect of test conditions on 
Fv/Fm is quite small in terms of F-statistics. The presence of neighbours may place additional strain on species resulting in increased sensitivity to atrazine and glyphosate.

Previous studies have had limited success in using $\mathrm{Fv} / \mathrm{Fm}$ to differentiate environmental conditions. For example, Smith and Moss (1998) found no differences in Fv/Fm for control and flooded conditions for different plant species and Cechin, et al. (2006) found that Fv/Fm did not change under water stressed and control conditions. However, several studies have found that subtle differences in test conditions confound interpretation of Fv/Fm data. Conrad, et al. (1993) found that the sensitivity of algae exposed to triazine herbicides, including atrazine, was affected by the physiological status of cells and was influenced by the age of cells. Toxicity has also been shown to be affected by microclimate and influenced by factors such as $\mathrm{CO}_{2}$ availability, temperature and developmental stage (Snel, et al., 1998) as well as solar radiation (Christensen, et al., 2003).

Leaves of plants grown under high light have smaller surface areas, are thicker, have higher rates of $\mathrm{CO}_{2}$ assimilation, more electron transport chains and are better adapted to stress (light) (Lichtenthaler, 1996). This might explain why plants in the outdoor microcosms were less sensitive than those in the greenhouse. The fact that there were differences in Fv/Fm for greenhouse and long-term microcosms on day 7 was a concern because at day 7 , the two test types should be replicates of each other. Krugh and Miles (1996) found that plants that were planted and grown together exhibited Fv/Fm characteristics with greater similarity than plants planted on separate days but grown in the same environmental conditions. They also found that the same group of plants was found to yield different fluorescence data following 24 hours of growth, suggesting that 
even subtle changes in growth stage can have large effects (Krugh and Miles, 1996). However, in contrast to this study, no concentration related effects on Fv/Fm were observed for the pesticides they used. Differences observed in test conditions, albeit fairly small, highlight that toxicity is dependent on test conditions as well as initial starting conditions. Since these effects are not always easily accounted for statistically, care should be taken in extrapolating from simplified tests to more complex systems.

$\mathrm{R}^{2}$ values for models examining the effect of test condition, species and concentration on percent control $\mathrm{Fv} / \mathrm{Fm}$ were high, indicating that $\mathrm{Fv} / \mathrm{Fm}$ is a useful parameter for examining these variables, particularly concentration. Strong correlations between biomass and Fv/Fm were found, further indicating that $\mathrm{Fv} / \mathrm{Fm}$ is a useful parameter to detect herbicide damage from atrazine or glyphosate. Previous studies have also found a strong link between Fv/Fm and growth measures (Barbagallo, et al., 2003; Christensen, et al., 2003; Abbaspoor, et al., 2006). However, unscaled Fv/Fm data are far less sensitive than biomass. Visual inspection of dose-response curves generated from this study suggests that $\mathrm{IC}_{25}$ values calculated from $\mathrm{Fv} / \mathrm{Fm}$ data would be much higher than they were for biomass.

The apparent lack of sensitivity in Fv/Fm values is a function of two factors. The first is that fluorescence measurements can only be taken on parts of a plant that are performing photosynthesis. This can sometimes create a distorted picture of plant health. For example, Ferrell, et al. (2003) found that Fv/Fm remained high for plants with very low net carbon assimilation and Kaňa, et al. (2004) found that large changes in levels of chlorophyll resulted in only minor changes in Fv/Fm. Similarly, in this study it was not 
uncommon to observe plants with high Fv/Fm but low biomass. This problem could be solved by integrating measures of leaf surface area with Fv/Fm.

The second factor affecting the sensitivity of $\mathrm{Fv} / \mathrm{Fm}$ is the range of values. Fv/Fm values for healthy plants range between 0.79 to 0.84 (Rosenqvist and van Kooten, 2003), although higher values have been observed (e.g. 0.858, Krugh and Miles, 1996). Average Fv/Fm values were reduced by $8.5 \%$ and $41 \%$ for the middle and highest doses respectively. The range of doses was selected to acheive a $20-80 \%$ reduction in biomass so that $\mathrm{IC}_{25}$ values could be accurately calculated. A study of the relationship between biochemical reactions in photosystem II and fluorescence parameters confirmed that Fv/Fm has a narrow range of change (estimated at 18 percentange points) and is relatively insensitive to change (Force, et al., 2003). This characteristic is advantageous in that Fv/Fm values are not wildly affected by small perturbations. However, it is disadvantageous in that a direct substitution for biomass would result in much higher $\mathrm{IC}_{25}$ values. It is recommended that $\mathrm{Fv} / \mathrm{Fm}$ be weighted or adjusted to account for the narrower range of response compared to biomass if it is used to calculate $\mathrm{IC}_{25}$ values.

\subsection{CONCLUSIONS}

The chlorophyll $a$ fluorescence parameter, Fv/Fm, can be used as a nondestructive early indicator of herbicide damage. Values of Fv/Fm are strongly affected by both glyphosate and atrazine in a dose-response manner. However, since the range of response of Fv/Fm is small, values should be weighted if they are to be used to calculate $\mathrm{IC}_{25}$ values meant to be comparable to those derived from biomass. In this experiment, Fv/Fm values were lower for plants grown in greenhouse microcosms compared to those 
grown singly in pots at the average overall herbicide concentration. Although Fv/Fm should not replace biomass as an endpoint in phytotoxicity testing, it can provide useful additional information, particularly for field populations or where early detection of herbicidal damage is desired. 
Table 3.1. Summary of type III sum of squares general linear models assessing the effects of day, species and concentration on percentage of control $\mathrm{Fv} / \mathrm{Fm}$ values for terrestrial plants treated with glyphosate and atrazine under different test conditions. $(\mathrm{F}=\mathrm{F}$ statistic, $\mathrm{df}=$ variable and error degrees of freedom, $\mathrm{P}=$ significance at $<\mathbf{0 . 0 5}$ )

\begin{tabular}{|c|c|c|c|c|c|c|c|c|}
\hline & \multicolumn{4}{|c|}{ Glyphosate } & \multicolumn{4}{|c|}{ Atrazine } \\
\hline Model & $\begin{array}{l}\text { Definitive } \\
\text { Single } \\
\text { Species }\end{array}$ & $\begin{array}{l}\text { Greenhouse } \\
\text { Microcosms }\end{array}$ & $\begin{array}{l}\text { Long-term } \\
\text { Microcosms }\end{array}$ & $\begin{array}{l}\text { Outdoor } \\
\text { Microcosms }\end{array}$ & $\begin{array}{l}\text { Definitive } \\
\text { Single } \\
\text { Species }\end{array}$ & $\begin{array}{l}\text { Greenhouse } \\
\text { Microcosms }\end{array}$ & $\begin{array}{l}\text { Long-term } \\
\text { Microcosms }\end{array}$ & $\begin{array}{l}\text { Outdoor } \\
\text { Microcosms }\end{array}$ \\
\hline $\begin{array}{l}\text { Dependent } \\
\text { Variable } \\
\text { Transformation }\end{array}$ & $y^{4}$ & $y^{4}$ & $y^{4}$ & $y^{4}$ & $y^{3}$ & $y^{3}$ & $y^{2}$ & None \\
\hline Day & $\begin{array}{l}F=0.573 d f= \\
3,110 \\
P=0.634\end{array}$ & $\begin{array}{l}F=1.634 \\
d f=3,111 \\
P=0.186\end{array}$ & $\begin{array}{l}\mathrm{F}=0.129 \\
\mathrm{df}=3,110 \\
\mathrm{P}=0.943\end{array}$ & N/A & $\begin{array}{l}\mathrm{F}=10.552 \\
\mathrm{df}=3,104 \\
\mathbf{P}<\mathbf{0 . 0 0 1}\end{array}$ & $\begin{array}{l}\mathrm{F}=4.117 \\
\mathrm{df}=3,107 \\
\mathbf{P}=\mathbf{0 . 0 0 8}\end{array}$ & $\begin{array}{l}\mathrm{F}=1.437 \\
\mathrm{df}=3,11 \\
\mathrm{P}=0.236\end{array}$ & N/A \\
\hline Species & $\begin{array}{l}\mathrm{F}=5.300 \\
\mathrm{df}=1,110 \\
\mathbf{P}=\mathbf{0 . 0 2 3}\end{array}$ & $\begin{array}{l}\mathrm{F}=14.982 \\
\mathrm{df}=1,111 \\
\mathrm{P}<\mathbf{0 . 0 0 1}\end{array}$ & $\begin{array}{l}\mathrm{F}=4.271 \\
\mathrm{df}=1,110 \\
P=\mathbf{0 . 0 4 1}\end{array}$ & $\begin{array}{l}F=6.885 \\
\mathrm{df}=1,26 \\
\mathbf{P}=\mathbf{0 . 0 1 4}\end{array}$ & $\begin{array}{l}F=470.544 \\
\mathrm{df}=1,104 \\
P<\mathbf{0 . 0 0 1}\end{array}$ & $\begin{array}{l}\mathrm{F}=8.701 \\
\mathrm{df}=1,107 \\
\mathrm{P}=\mathbf{0 . 0 0 4}\end{array}$ & $\begin{array}{l}F=9.085 \\
\mathrm{df}=1,111 \\
P=\mathbf{0 . 0 0 3}\end{array}$ & $\begin{array}{l}\mathrm{F}=7.436 \\
\mathrm{df}=1,27 \\
\mathbf{P}=\mathbf{0 . 0 1 1}\end{array}$ \\
\hline Concentration & $\begin{array}{l}\mathrm{F}=74.879 \\
\mathrm{df}=1,110 \\
\mathrm{P}<\mathbf{0 . 0 0 1}\end{array}$ & $\begin{array}{l}F=141.208 \\
d f=1,111 \\
P<0.001\end{array}$ & $\begin{array}{l}\mathrm{F}=133.923 \\
\mathrm{df}=1,110 \\
\mathbf{P}<\mathbf{0 . 0 0 1}\end{array}$ & $\begin{array}{l}F=23.468 \\
\mathrm{df}=1,26 \\
\mathrm{P}<\mathbf{0 . 0 0 1}\end{array}$ & $\begin{array}{l}F=689.523 \\
d f=1,104 \\
P<0.001\end{array}$ & $\begin{array}{l}F=196.283 \\
d f=1,107 \\
P<\mathbf{0 . 0 0 1}\end{array}$ & $\begin{array}{l}F=125.629 \\
\mathrm{df}=1,111 \\
P<\mathbf{0 . 0 0 1}\end{array}$ & $\begin{array}{l}F=15.309 \\
\mathrm{df}=1,27 \\
\mathbf{P}=\mathbf{0 . 0 0 1}\end{array}$ \\
\hline Day* Species & $\begin{array}{l}\mathrm{F}=1.619 \\
\mathrm{df}=3,110 \\
\mathrm{P}=0.189\end{array}$ & $\begin{array}{l}F=1.789 \\
d f=3,111 \\
P=0.153\end{array}$ & $\begin{array}{l}F=1.689 \\
d f=3,110 \\
P=0.174\end{array}$ & N/A & $\begin{array}{l}\mathrm{F}=12.666 \\
\mathrm{df}=3,104 \\
\mathbf{P}<\mathbf{0 . 0 0 1}\end{array}$ & $\begin{array}{l}F=0.918 \\
d f=3,107 \\
P=0.435\end{array}$ & $\begin{array}{l}\mathrm{F}=0.036 \\
\mathrm{df}=3,111 \\
\mathrm{P}=0.991\end{array}$ & N/A \\
\hline $\begin{array}{l}\text { Day* } \\
\text { Concentration }\end{array}$ & N/A & N/A & N/A & N/A & $\begin{array}{l}\mathrm{F}=5.786 \\
\mathrm{df}=3,104 \\
\mathbf{P}=\mathbf{0 . 0 0 1}\end{array}$ & $\begin{array}{l}F=4.034 \\
\mathrm{df}=3,107 \\
\mathbf{P}=\mathbf{0 . 0 0 9}\end{array}$ & N/A & N/A \\
\hline $\begin{array}{l}\text { Species* } \\
\text { Concentration }\end{array}$ & $\begin{array}{l}F=4.037 \\
d f=1,110 \\
P=0.047\end{array}$ & N/A & $\begin{array}{l}F=6.650 \\
d f=1,110 \\
P=0.011\end{array}$ & $\begin{array}{l}\mathrm{F}=8.819 \\
\mathrm{df}=1,26 \\
\mathrm{P}=\mathbf{0 . 0 0 6}\end{array}$ & $\begin{array}{l}\mathrm{F}=459.546 \\
\mathrm{df}=1,104 \\
\mathbf{P}<\mathbf{0 . 0 0 1}\end{array}$ & $\begin{array}{l}F=6.323 \\
d f=1,107 \\
P=0.013\end{array}$ & N/A & N/A \\
\hline $\begin{array}{l}\text { Day* Species * } \\
\text { Concentration }\end{array}$ & N/A & N/A & N/A & N/A & $\begin{array}{l}\mathrm{F}=14.237 \\
\mathrm{df}=3,104 \\
\mathbf{P}<\mathbf{0 . 0 0 1}\end{array}$ & N/A & N/A & N/A \\
\hline R-Squared & 0.436 & 0.600 & 0.599 & 0.593 & 0.922 & 0.690 & 0.556 & 0.457 \\
\hline
\end{tabular}


Table 3.2. Summary of type III sum of squares general linear models assessing the effects of day, species and concentration on percentage of control $\mathrm{Fv} / \mathrm{Fm}$ values for wetland plants treated with glyphosate and atrazine under different test conditions $(\mathrm{F}=\mathrm{F}$ statistic, $\mathrm{df}=$ variable and error degrees of freedom, $\mathrm{P}=$ significance at $<\mathbf{0 . 0 5}$ )

\begin{tabular}{|c|c|c|c|c|c|c|}
\hline 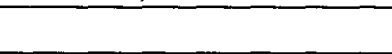 & \multicolumn{3}{|c|}{ Glyphosate } & \multicolumn{3}{|c|}{ Atrazine } \\
\hline Model & $\begin{array}{l}\text { Definitive Single } \\
\text { Species }\end{array}$ & $\begin{array}{l}\text { Greenhouse } \\
\text { Microcosms }\end{array}$ & $\begin{array}{l}\text { Long-term } \\
\text { Microcosms }\end{array}$ & $\begin{array}{l}\text { Definitive Single } \\
\text { Species }\end{array}$ & $\begin{array}{l}\text { Greenhouse } \\
\text { Microcosms }\end{array}$ & $\begin{array}{l}\text { Long-term } \\
\text { Microcosms }\end{array}$ \\
\hline $\begin{array}{l}\text { Dependent Variable } \\
\text { Transformation }\end{array}$ & $y^{4}$ & $y^{2}$ & $y^{2}$ & $y^{4}$ & None & $y^{3}$ \\
\hline Day & $\begin{array}{l}\mathrm{F}=10.920 \\
\mathrm{df}=3,110 \\
\mathbf{P}<\mathbf{0 . 0 0 1}\end{array}$ & $\begin{array}{l}\mathrm{F}=7.303 \\
\mathrm{df}=1,55 \\
\mathbf{P}=\mathbf{0 . 0 0 9}\end{array}$ & $\begin{array}{l}\mathrm{F}=0.261 \\
\mathrm{df}=1,54 \\
\mathrm{P}=0.612\end{array}$ & $\begin{array}{l}\mathrm{F}=12.130 \\
\mathrm{df}=3,111 \\
\mathrm{P}<\mathbf{0 . 0 0 1}\end{array}$ & $\begin{array}{l}F=2.104 \\
d f=1,55 \\
P=0.153\end{array}$ & $\begin{array}{l}\mathrm{F}=9.557 \\
\mathrm{df}=1,54 \\
\mathbf{P}=\mathbf{0 . 0 0 3}\end{array}$ \\
\hline Species & $\begin{array}{l}\mathrm{F}=21.254 \\
\mathrm{df}=1,110 \\
\mathrm{P}<\mathbf{0 . 0 0 1}\end{array}$ & $\begin{array}{l}F=0.605 \\
d f=1,55 \\
P=0.440\end{array}$ & $\begin{array}{l}\mathrm{F}=3.861 \\
\mathrm{df}=1,54 \\
\mathrm{P}=0.055\end{array}$ & $\begin{array}{l}\mathrm{F}=10.180 \\
\mathrm{df}=1,111 \\
\mathrm{P}=\mathbf{0 . 0 0 2}\end{array}$ & $\begin{array}{l}\mathrm{F}=11.201 \\
\mathrm{df}=1,55 \\
\mathbf{P}=\mathbf{0 . 0 0 1}\end{array}$ & $\begin{array}{l}\mathrm{F}=1.604 \\
\mathrm{df}=1,54 \\
\mathrm{P}=0.211\end{array}$ \\
\hline Concentration & $\begin{array}{l}F=118.896 \\
d f=1,110 \\
P<0.001\end{array}$ & $\begin{array}{l}\mathrm{F}=98.482 \\
\mathrm{df}=1,55 \\
\mathrm{P}<\mathbf{0 . 0 0 1}\end{array}$ & $\begin{array}{l}\mathrm{F}=67.563 \\
\mathrm{df}=1,54 \\
P<\mathbf{0 . 0 0 1}\end{array}$ & $\begin{array}{l}\mathrm{F}=129.502 \\
\mathrm{df}=1,111 \\
\mathrm{P}<\mathbf{0 . 0 0 1}\end{array}$ & $\begin{array}{l}\mathrm{F}=55.726 \\
\mathrm{df}=1,55 \\
\mathrm{P}<\mathbf{0 . 0 0 1}\end{array}$ & $\begin{array}{l}\mathrm{F}=190.444 \\
\mathrm{df}=1,54 \\
\mathbf{P}<\mathbf{0 . 0 0 1}\end{array}$ \\
\hline Day* Species & $\begin{array}{l}\mathrm{F}=0.480 \\
\mathrm{df}=3,110 \\
\mathrm{P}=0.697\end{array}$ & $\begin{array}{l}\mathrm{F}=0.373 \\
\mathrm{df}=1,55 \\
\mathrm{P}=0.544\end{array}$ & $\begin{array}{l}\mathrm{F}=0.002 \\
\mathrm{df}=1,54 \\
\mathrm{P}=0.967\end{array}$ & $\begin{array}{l}\mathrm{F}=0.702 \\
\mathrm{df}=3,111 \\
\mathrm{P}=0.553\end{array}$ & $\begin{array}{l}\mathrm{F}=8.421 \\
\mathrm{df}=1,55 \\
\mathrm{P}=\mathbf{0 . 0 0 5}\end{array}$ & $\begin{array}{l}\mathrm{F}=0.219 \\
\mathrm{df}=1,54 \\
\mathrm{P}=0.642\end{array}$ \\
\hline Day* Concentration & N/A & N/A & N/A & N/A & N/A & $\begin{array}{l}\mathrm{F}=8.167 \\
\mathrm{df}=1.54 \\
\mathrm{P}=\mathbf{0 . 0 0 6}\end{array}$ \\
\hline Species* Concentration & $\begin{array}{l}\mathrm{F}=29.375 \\
\mathrm{df}=1,110 \\
\mathrm{P}<\mathbf{0 . 0 0 1}\end{array}$ & N/A & $\begin{array}{l}\mathrm{F}=4.631 \\
\mathrm{df}=1,54 \\
\mathbf{P}=\mathbf{0 . 0 3 6}\end{array}$ & N/A & N/A & N/A \\
\hline $\begin{array}{l}\text { Day* Species* } \\
\text { Concentration }\end{array}$ & $\mathrm{N} / \mathrm{A}$ & N/A & N/A & N/A & N/A & N/A \\
\hline R-Squared & 0.661 & 0.660 & 0.577 & 0.616 & 0.585 & 0.791 \\
\hline
\end{tabular}


Table 3.3. Summary of type III sum of squares general linear models assessing the effects of test condition, species and herbicide concentration on percent control $\mathrm{Fv} / \mathrm{Fm}$. Day 7 measurements were taken on terrestrial and wetland plants grown singly in pots and in greenhouse microcosms (in greenhouse and long-term microcosm tests) $(\mathrm{F}=\mathrm{F}$ statistic, $\mathrm{df}=$ independent variable and error degrees of freedom, $\mathrm{P}=$ significance at $<\mathbf{0 . 0 5}$ ).

\begin{tabular}{|c|c|c|c|c|}
\hline Model & $\begin{array}{l}\text { Glyphosate } \\
\text { Terrestrial Tests }\end{array}$ & $\begin{array}{l}\text { Atrazine } \\
\text { Terrestrial Tests }\end{array}$ & $\begin{array}{l}\text { Glyphosate } \\
\text { Wetland Tests }\end{array}$ & $\begin{array}{l}\text { Atrazine } \\
\text { Wetland Tests }\end{array}$ \\
\hline $\begin{array}{l}\text { Dependent } \\
\text { Variable } \\
\text { Transformation }\end{array}$ & (1) & 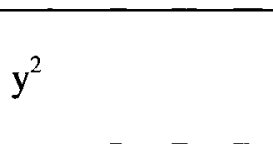 & $y^{3}$ & $y^{2}$ \\
\hline Test & $\begin{array}{l}\mathrm{F}=3.813 \\
\mathrm{df}=2,82 \\
\mathbf{P}=\mathbf{0 . 0 2 6}\end{array}$ & $\begin{array}{l}\mathrm{F}=6.475 \\
\mathrm{df}=2,78 \\
P=\mathbf{0 . 0 0 3}\end{array}$ & $\begin{array}{l}\mathrm{F}=0.614 \\
\mathrm{df}=2,78 \\
\mathrm{P}=0.544\end{array}$ & $\begin{array}{l}\mathrm{F}=9.209 \\
\mathrm{df}=2,83 \\
\mathrm{P}<\mathbf{0 . 0 0 1}\end{array}$ \\
\hline Species & $\begin{array}{l}\mathrm{F}=3.855 \\
\mathrm{df}=1,82 \\
\mathrm{P}=0.053\end{array}$ & $\begin{array}{l}\mathrm{F}=24.023 \\
\mathrm{df}=1,78 \\
\mathrm{P}<\mathbf{0 . 0 0 1}\end{array}$ & $\begin{array}{l}\mathrm{F}=11.956 \\
\mathrm{df}=1,78 \\
\mathbf{P}=\mathbf{0 . 0 0 1}\end{array}$ & $\begin{array}{l}F=2.199 \\
d f=1,83 \\
P=0.142\end{array}$ \\
\hline Concentration & $\begin{array}{l}\mathrm{F}=152.036 \\
\mathrm{df}=1,82 \\
\mathrm{P}<\mathbf{0 . 0 0 1}\end{array}$ & $\begin{array}{l}\mathrm{F}=101.581 \\
\mathrm{df}=1,78 \\
\mathbf{P}<\mathbf{0 . 0 0 1}\end{array}$ & $\begin{array}{l}F=203.718 \\
d f=1,78 \\
P<\mathbf{0 . 0 0 1}\end{array}$ & $\begin{array}{l}\mathrm{F}=169.218 \\
\mathrm{df}=1,83 \\
\mathrm{P}<\mathbf{0 . 0 0 1}\end{array}$ \\
\hline Test* Species & $\begin{array}{l}\mathrm{F}=1.315 \\
\mathrm{df}=2,82 \\
\mathrm{P}=0.274\end{array}$ & $\begin{array}{l}\mathrm{F}=7.470 \\
\mathrm{df}=2,78 \\
\mathbf{P}=\mathbf{0 . 0 0 1}\end{array}$ & $\begin{array}{l}\mathrm{F}=2.700 \\
\mathrm{df}=2,78 \\
\mathrm{P}=0.074\end{array}$ & $\begin{array}{l}F=0.444 \\
d f=2,83 \\
P=0.643\end{array}$ \\
\hline $\begin{array}{l}\text { Test* } \\
\text { Concentration }\end{array}$ & N/A & $\begin{array}{l}\mathrm{F}=5.224 \\
\mathrm{df}=2,78 \\
\mathbf{P}=\mathbf{0 . 0 0 7}\end{array}$ & N/A & N/A \\
\hline $\begin{array}{l}\text { Species* } \\
\text { Concentration }\end{array}$ & $\begin{array}{l}\mathrm{F}=11.512 \\
\mathrm{df}=1,82 \\
\mathbf{P}=\mathbf{0 . 0 0 1}\end{array}$ & $\begin{array}{l}\mathrm{F}=21.510 \\
\mathrm{df}=1,78 \\
\mathbf{P}<\mathbf{0 . 0 0 1}\end{array}$ & $\begin{array}{l}\mathrm{F}=14.639 \\
\mathrm{df}=1,78 \\
\mathrm{P}<\mathbf{0 . 0 0 1}\end{array}$ & N/A \\
\hline $\begin{array}{l}\text { Test* Species * } \\
\text { Concentration }\end{array}$ & N/A & $\begin{array}{l}\mathrm{F}=7.776 \\
\mathrm{df}=2,78 \\
\mathbf{P}=\mathbf{0 . 0 0 1}\end{array}$ & $\begin{array}{l}\mathrm{F}=2.314 \\
\mathrm{df}=4,78 \\
\mathrm{P}=0.065\end{array}$ & N/A \\
\hline R-Squared & 0.774 & 0.635 & 0.766 & 0.710 \\
\hline
\end{tabular}


Table 3.4. Summary of type III sum of squares general linear models assessing the effects of test condition, species and herbicide concentration on percent control Fv/Fm. Day 28 measurements were taken on terrestrial plants grown singly in pots, in greenhouse microcosms (in greenhouse and long-term microcosm tests) and in outdoor microcosms. $(\mathrm{F}=\mathrm{F}$ statistic, $\mathrm{df}=$ independent variable and error degrees of freedom, $\mathrm{P}=$ significance at $<\mathbf{0 . 0 5}$ ).

\begin{tabular}{|c|c|c|}
\hline Model & Glyphosate Terrestrial Tests & Atrazine Terrestrial Tests \\
\hline $\begin{array}{l}\text { Dependent Variable } \\
\text { Transformation }\end{array}$ & s & - \\
\hline Test & $\begin{array}{l}\mathrm{F}=2.801 \\
\mathrm{df}=3,111 \\
\mathbf{P}=\mathbf{0 . 0 4 3}\end{array}$ & $\begin{array}{l}\mathrm{F}=6.318 \\
\mathrm{df}=3,104 \\
\mathbf{P}=\mathbf{0 . 0 0 1}\end{array}$ \\
\hline Species & $\begin{array}{l}\mathrm{F}=0.043 \\
\mathrm{df}=1,111 \\
\mathrm{P}=0.836\end{array}$ & $\begin{array}{l}\mathrm{F}=27.666 \\
\mathrm{df}=1,104 \\
\mathbf{P}<\mathbf{0 . 0 0 1}\end{array}$ \\
\hline Concentration & $\begin{array}{l}\mathrm{F}=77.627 \\
\mathrm{df}=1,111 \\
\mathrm{P}<\mathbf{0 . 0 0 1}\end{array}$ & $\begin{array}{l}\mathrm{F}=148.575 \\
\mathrm{df}=1,104 \\
\mathrm{P}<\mathbf{0 . 0 0 1}\end{array}$ \\
\hline Test* Species & $\begin{array}{l}F=1.466 \\
\mathrm{df}=3,111 \\
\mathrm{P}=0.228\end{array}$ & $\begin{array}{l}\mathrm{F}=11.870 \\
\mathrm{df}=3,104 \\
\mathrm{P}<\mathbf{0 . 0 0 1}\end{array}$ \\
\hline Test* Concentration & N/A & $\begin{array}{l}\mathrm{F}=5.235 \\
\mathrm{df}=3,104 \\
\mathbf{P}=\mathbf{0 . 0 0 2}\end{array}$ \\
\hline Species* Concentration & N/A & $\begin{array}{l}\mathrm{F}=23.103 \\
\mathrm{df}=1,104 \\
\mathbf{P}<\mathbf{0 . 0 0 1}\end{array}$ \\
\hline Test* Species * Concentration & N/A & $\begin{array}{l}\mathrm{F}=12.694 \\
\mathrm{df}=3,104 \\
\mathrm{P}<\mathbf{0 . 0 0 1}\end{array}$ \\
\hline R-Squared & 0.452 & 0.701 \\
\hline
\end{tabular}


Table 3.5. Summary of the main effects of test condition and species on percent control Fv/Fm seven days after spray for terrestrial and wetland plants sprayed with glyphosate and atrazine. The estimated marginal geometric means are shown with $95 \%$ confidence intervals indicated in brackets. The means were evaluated at the overall average concentration value for each model using Sidak pairwise-comparisons. Means followed by the same letter are not significantly different while means followed by different letters are significantly different from each other at the estimated marginal geometric means.

\begin{tabular}{|c|c|c|c|c|c|c|c|}
\hline$x_{1}$ & Day 7 & & Day 28 & & & Day 7 & \\
\hline $\begin{array}{l}\text { Terrestrial } \\
\text { Test }\end{array}$ & $\begin{array}{l}\text { Glyphosate } \\
\text { Terrestrial } \\
\text { Tests }\end{array}$ & $\begin{array}{l}\text { Atrazine } \\
\text { Terrestrial } \\
\text { Tests }\end{array}$ & $\begin{array}{l}\text { Glyphosate } \\
\text { Terrestrial } \\
\text { Tests }\end{array}$ & $\begin{array}{l}\text { Atrazine } \\
\text { Terrestrial } \\
\text { Tests }\end{array}$ & $\begin{array}{l}\text { Wetland } \\
\text { Test }\end{array}$ & $\begin{array}{l}\text { Glyphosate } \\
\text { Wetland Tests }\end{array}$ & $\begin{array}{l}\text { Atrazine } \\
\text { Wetland } \\
\text { Tests }\end{array}$ \\
\hline Single Species & $\begin{array}{c}0.9518^{\mathrm{a}} \\
(0.9390- \\
0.9641) \\
\end{array}$ & $\begin{array}{c}0.8743^{\mathrm{a}} \\
(0.8353- \\
0.9115) \\
\end{array}$ & $\begin{array}{c}0.9664^{\mathrm{a}} \\
(0.9370- \\
0.9934) \\
\end{array}$ & $\begin{array}{c}0.9995^{\mathrm{a}} \\
(0.9704- \\
1.0262) \\
\end{array}$ & Single Species & $\begin{array}{c}0.8700^{\mathrm{a}} \\
(0.8449- \\
0.8936) \\
\end{array}$ & $\begin{array}{c}0.8025^{\mathrm{a}} \\
(0.7780- \\
0.8263) \\
\end{array}$ \\
\hline $\begin{array}{l}\text { Greenhouse } \\
\text { Microcosm }\end{array}$ & $\begin{array}{c}\mathbf{0 . 9 2 8 6}^{\mathbf{b}} \\
(0.9150- \\
0.9416)\end{array}$ & $\begin{array}{c}\mathbf{0 . 7 9 9 4}^{\mathbf{b}} \\
(0.7733- \\
0.8247)\end{array}$ & $\begin{array}{c}\mathbf{0 . 9 0 7 8}^{\mathbf{a}} \\
(0.8717- \\
0.9400)\end{array}$ & $\begin{array}{c}\mathbf{0 . 8 5 2 6}^{\mathbf{c}} \\
(0.8237- \\
0.8787)\end{array}$ & $\begin{array}{l}\text { Greenhouse } \\
\text { Microcosm }\end{array}$ & $\begin{array}{c}\mathbf{0 . 8 1 9 4}^{\mathbf{b}} \\
(0.7911- \\
0.8459)\end{array}$ & $\begin{array}{c}\mathbf{0 . 7 2 4 9}^{\mathbf{b}} \\
(0.6977- \\
0.7511)\end{array}$ \\
\hline $\begin{array}{l}\text { Long-term } \\
\text { Microcosm }\end{array}$ & $\begin{array}{l}0.9314^{\text {ab }} \\
(0.9180- \\
0.9443) \\
\end{array}$ & $\begin{array}{l}0.8194^{\mathrm{ab}} \\
(0.7937- \\
0.8443) \\
\end{array}$ & $\begin{array}{c}0.9198^{\mathrm{a}} \\
(0.8853- \\
0.9509) \\
\end{array}$ & $\begin{array}{l}0.8927^{\text {bc }} \\
(0.8674- \\
0.9160)\end{array}$ & $\begin{array}{l}\text { Long-term } \\
\text { Microcosm }\end{array}$ & $\begin{array}{c}0.8747^{\mathrm{a}} \\
(0.8500- \\
0.8981) \\
\end{array}$ & $\begin{array}{l}0.7641^{\text {ab }} \\
(0.7384- \\
0.7890) \\
\end{array}$ \\
\hline $\begin{array}{l}\text { Outdoor } \\
\text { Microcosm }\end{array}$ & & & $\begin{array}{c}0.9435^{\mathrm{a}} \\
(0.9117- \\
0.9724) \\
\end{array}$ & $\begin{array}{c}0.9337^{b} \\
(0.9120- \\
0.9540)\end{array}$ & & & \\
\hline $\begin{array}{l}\text { Terrestrial } \\
\text { Species }\end{array}$ & & & & & $\begin{array}{l}\text { Wetland } \\
\text { Species }\end{array}$ & & \\
\hline G. canadense & $\begin{array}{c}0.9759^{\mathrm{a}} \\
(0.9664- \\
0.9852)\end{array}$ & $\begin{array}{c}\mathbf{0 . 8 0 6 0}^{b} \\
(0.7809- \\
0.8304)\end{array}$ & $\begin{array}{c}\mathbf{0 . 9 3 3 6}^{\mathrm{a}} \\
(0.9107- \\
0.9549)\end{array}$ & $\begin{array}{c}\mathbf{0 . 8 9 8 5}^{b} \\
(0.8791- \\
0.9168)\end{array}$ & E. maculatum & $\begin{array}{c}\mathbf{0 . 8 3 9 9}^{6} \\
(0.8181- \\
0.8607)\end{array}$ & $\begin{array}{c}\mathbf{0 . 7 5 3 5}^{\mathbf{a}} \\
(0.7323- \\
0.7742)\end{array}$ \\
\hline S. lateriflorum & $\begin{array}{c}\mathbf{0 . 8 9 3 5}^{\mathbf{b}} \\
\left(0.8810^{-}\right. \\
0.9054) \\
\end{array}$ & $\begin{array}{c}0.8565^{\mathrm{a}} \\
(0.8307- \\
0.8815) \\
\end{array}$ & $\begin{array}{c}0.9368^{\mathrm{a}} \\
(0.9142- \\
0.9580)\end{array}$ & $\begin{array}{c}0.9483^{a} \\
(0.9302- \\
0.9655) \\
\end{array}$ & L. americanus & $\begin{array}{c}0.8704^{\mathrm{a}} \\
(0.8501- \\
0.8898) \\
\end{array}$ & $\begin{array}{r}0.7753^{\mathrm{a}} \\
(0.7547- \\
0.7954) \\
\end{array}$ \\
\hline $\begin{array}{l}\text { Concentration } \\
\text { (g ai/ ha) }\end{array}$ & 281 & 228 & 281 & 221 & $\begin{array}{l}\text { Concentration } \\
\text { (g ai/ ha) }\end{array}$ & 156 & 222 \\
\hline
\end{tabular}


Table 3.6. Summary of nonparametric correlations between percent control biomass and percent control $\mathrm{Fv} / \mathrm{Fm}$ for terrestrial and wetland single species tests, greenhouse, outdoor and long-term microcosm tests treated with glyphosate and atrazine. Correlations between biomass and Fv/Fm were conducted using Fv/Fm values taken 7 days after spray as well as day 28 values for the terrestrial species. Long-term microcosms were analyzed separately because biomass measurements were taken 60 or 70 days after spray. Correlations are significant at $\mathrm{P}<0.05$.

\begin{tabular}{|c|c|c|c|c|c|}
\hline & & $\begin{array}{l}\text { Glyphosate } \\
\text { Terrestrial } \\
\text { Tests }\end{array}$ & $\begin{array}{l}\text { Atrazine } \\
\text { Terrestrial } \\
\text { Tests }\end{array}$ & $\begin{array}{l}\text { Glyphosate } \\
\text { Wetland } \\
\text { Tests }\end{array}$ & $\begin{array}{l}\text { Atrazine } \\
\text { Wetland } \\
\text { Tests }\end{array}$ \\
\hline $\begin{array}{l}\text { Day } 7 \mathrm{Fv} / \mathrm{Fm} \\
\text { Day } 28 \text { Biomass }\end{array}$ & $\begin{array}{l}\text { Spearman's rho } \\
\text { correlation } \\
\text { coefficient } \\
\text { 2-tailed } \\
\text { significance } \\
\text { Sample Size }\end{array}$ & $\begin{array}{l}0.587 \\
<0.001 \\
60\end{array}$ & $\begin{array}{l}0.741 \\
<0.001 \\
60\end{array}$ & $\begin{array}{l}0.845 \\
<0.001 \\
60\end{array}$ & $\begin{array}{l}0.904 \\
<0.001 \\
60\end{array}$ \\
\hline $\begin{array}{l}\text { Day } 7 \mathrm{Fv} / \mathrm{Fm} \\
\text { Day } 60 \text { or } 70 \\
\text { Biomass }\end{array}$ & $\begin{array}{l}\text { Spearman's rho } \\
\text { correlation } \\
\text { coefficient } \\
\text { 2-tailed } \\
\text { significance } \\
\text { Sample Size }\end{array}$ & $\begin{array}{l}0.785 \\
<0.001 \\
30\end{array}$ & $\begin{array}{l}0.686 \\
<0.001 \\
30\end{array}$ & $\begin{array}{l}0.759 \\
<0.001 \\
30\end{array}$ & $\begin{array}{l}0.851 \\
<0.001 \\
30\end{array}$ \\
\hline $\begin{array}{l}\text { Day } 28 \mathrm{Fv} / \mathrm{Fm} \\
\text { Day } 28 \text { Biomass }\end{array}$ & $\begin{array}{l}\text { Spearman's rho } \\
\text { correlation } \\
\text { coefficient } \\
\text { 2-tailed } \\
\text { significance } \\
\text { Sample Size }\end{array}$ & $\begin{array}{l}0.500 \\
<0.001 \\
90\end{array}$ & $\begin{array}{l}0.546 \\
<0.001 \\
90\end{array}$ & & \\
\hline $\begin{array}{l}\text { Day } 28 \mathrm{Fv} / \mathrm{Fm} \\
\text { Day } 60 \text { or } 70 \\
\text { Biomass }\end{array}$ & $\begin{array}{l}\text { Spearman's rho } \\
\text { correlation } \\
\text { coefficient } \\
\text { 2-tailed } \\
\text { significance } \\
\text { Sample Size }\end{array}$ & $\begin{array}{l}0.656 \\
<0.001 \\
30\end{array}$ & $\begin{array}{l}0.598 \\
<0.001 \\
30\end{array}$ & & \\
\hline
\end{tabular}




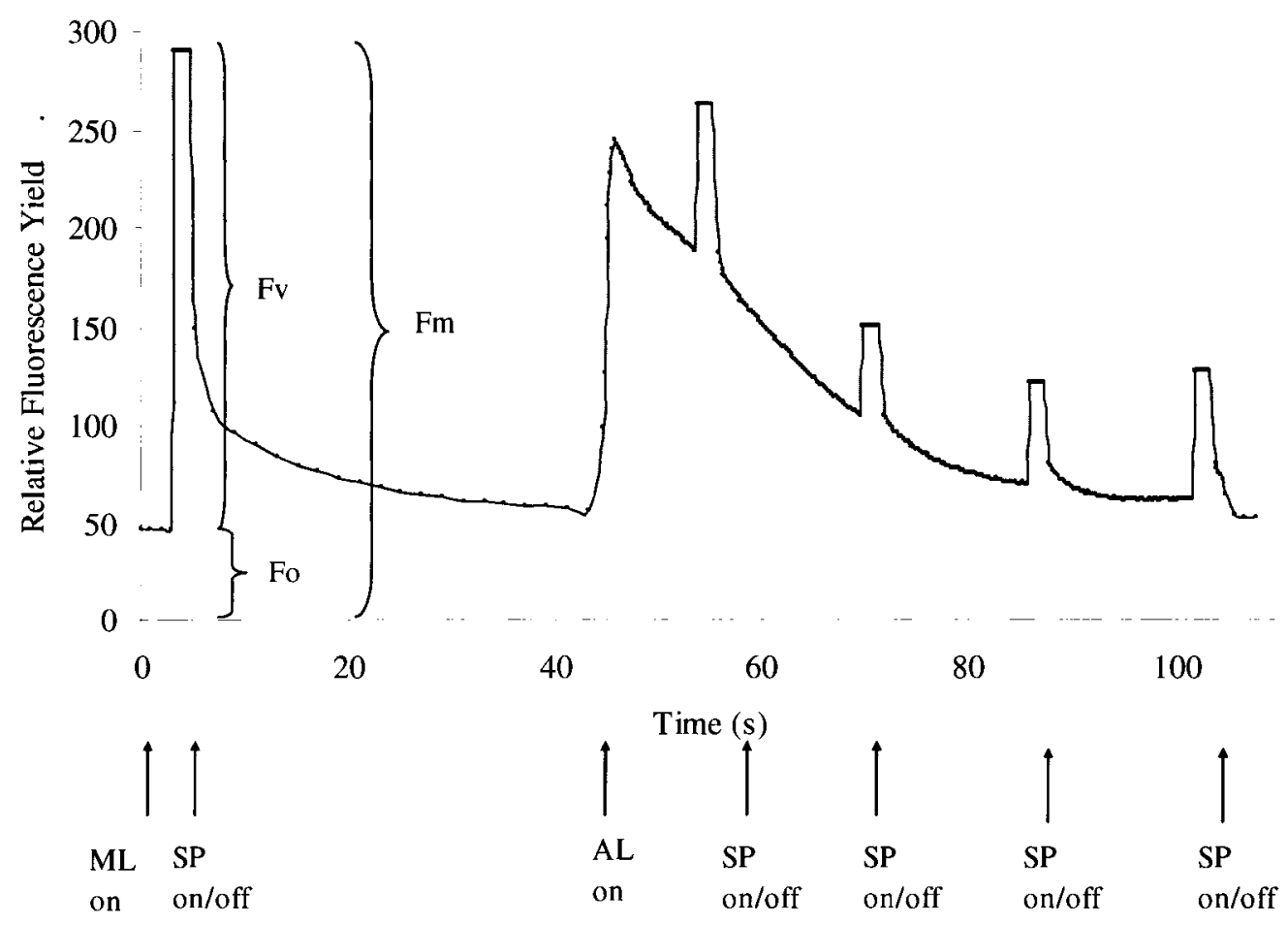

Figure 3.1. Example of a typical Kautsky curve, measured on a healthy L. americanus control plant seven days after the test period began. ML- measuring light, SP- saturating light pulse, AL- actinic light. The measuring light is insufficient to promote photosynthesis or non-photochemical quenching and measures the initial base fluorescence from excited chlorophyll molecules, Fo. A saturating actinic light is turned on and all $\mathrm{Q}_{\mathrm{A}}$ molecules are reduced, closing all reaction centres and causing fluorescence to rise to its maximum, Fm. The difference between Fo and Fm is caused by the closure of photosystem II and is termed, Fv. Subsequent exposure to actinic light will result in lower peaks as photochemistry and non-photochemical quenching of fluorescence begin to take effect. (Harbinson and Rosenqvist, 2003; Rosenqvist and van Kooten, 2003). 

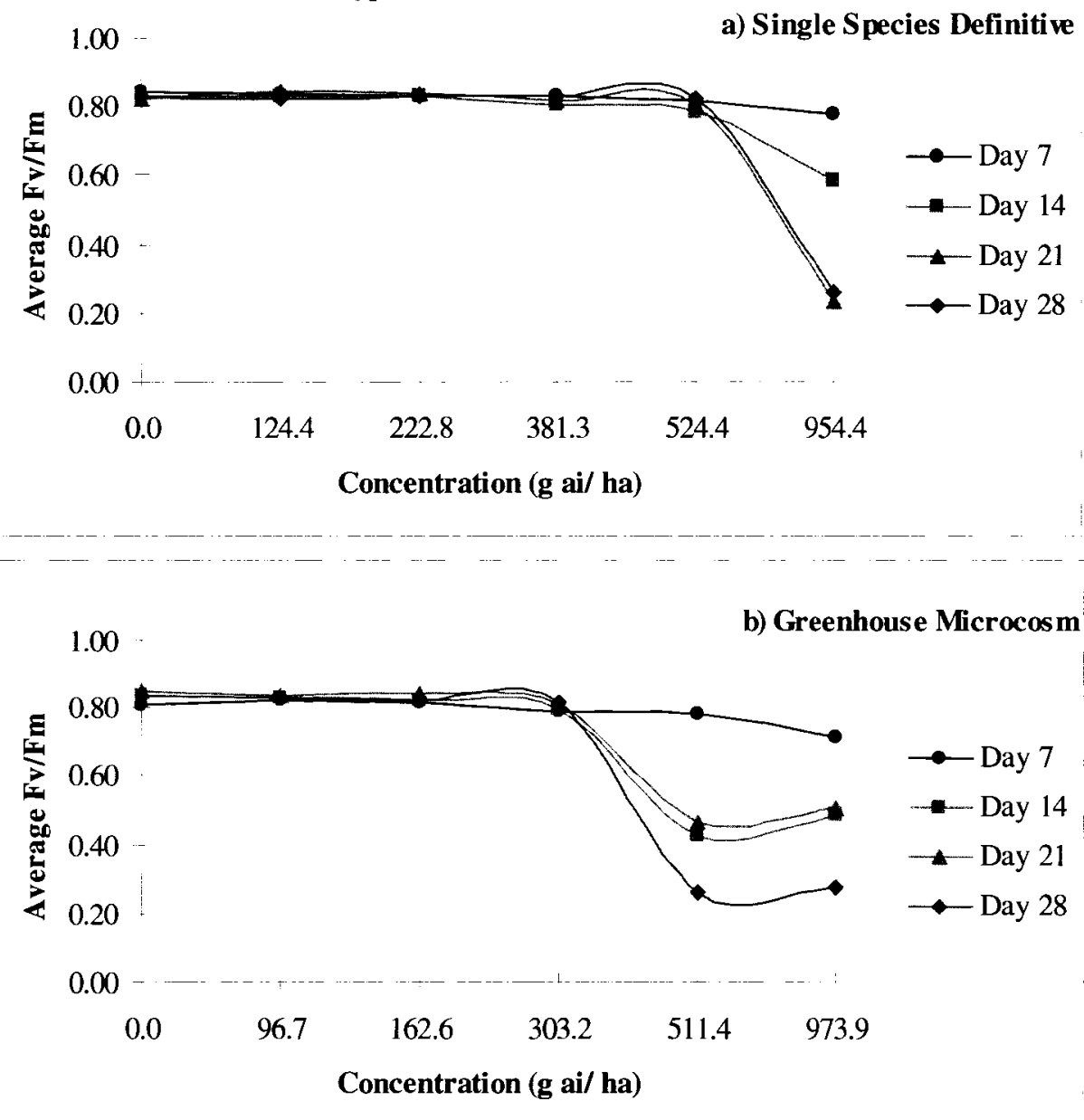

c) Long-Term Microcosm

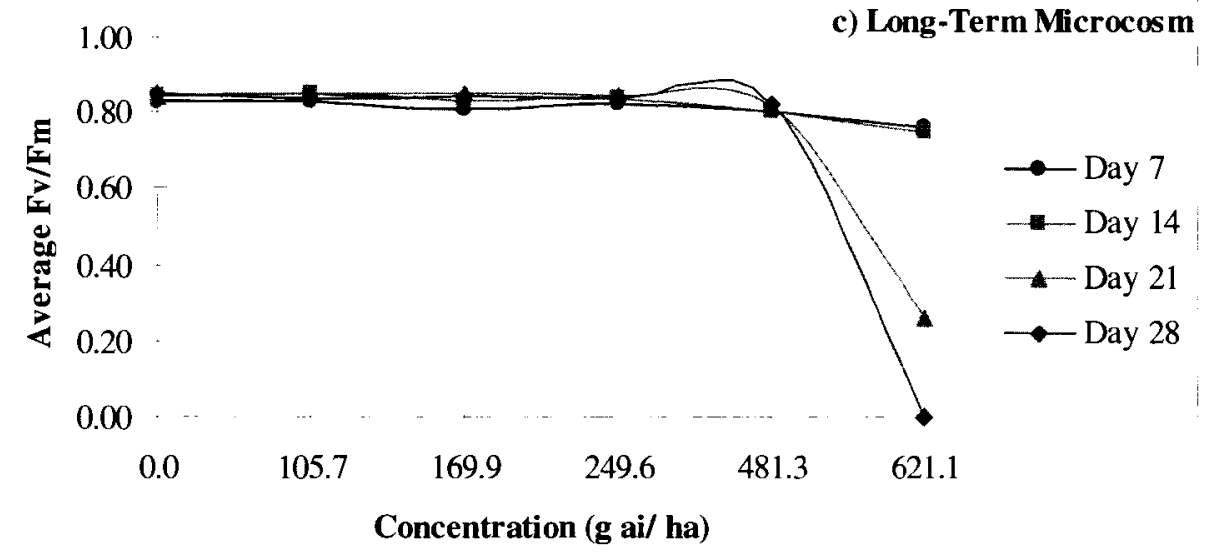

Figure 3.2. The effects of glyphosate on average Fv/Fm values 7, 14, 21 and 28 days after spray for the terrestrial species, $G$. canadense, grown a) singly in pots, b) in greenhouse microcosms and c) in long-term microcosms. 
Glyphosate- S. lateriflorum
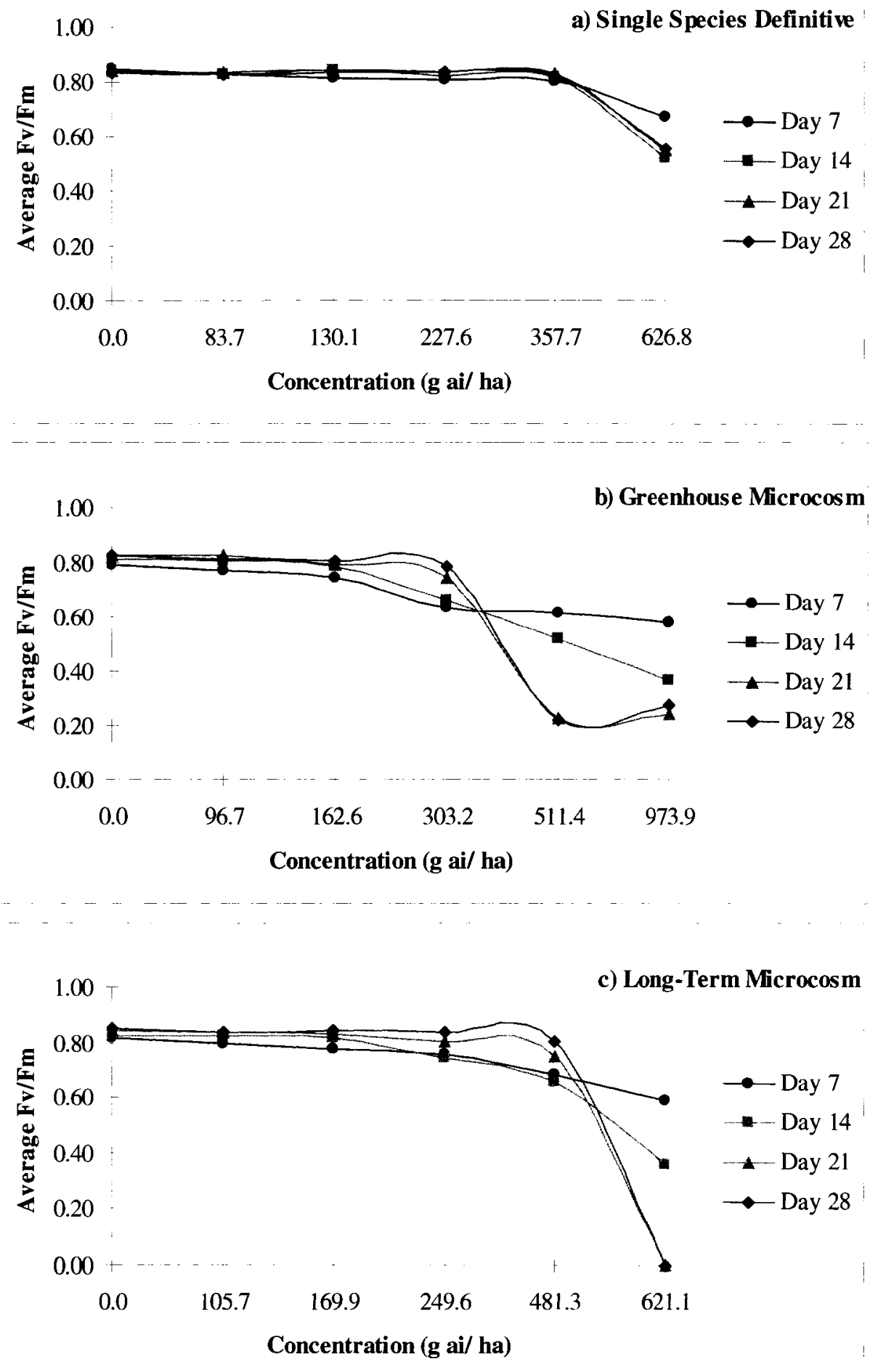

Figure 3.3. The effects of glyphosate on average Fv/Fm values 7, 14, 21 and 28 days after spray for the terrestrial species, $S$. lateriflorum, grown a) singly in pots, b) in greenhouse microcosms and c) in long-term microcosms. 

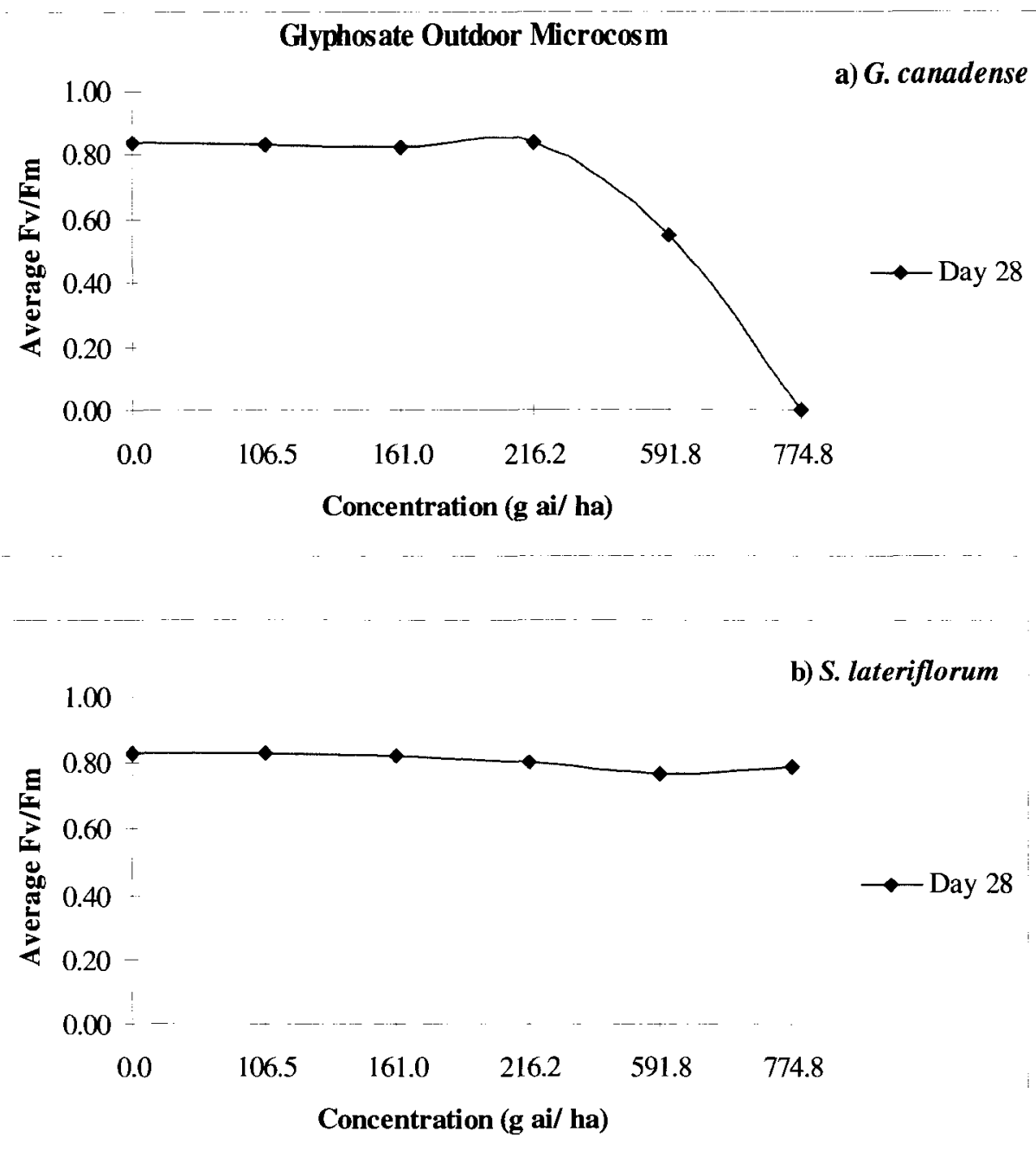

Figure 3.4. The effects of glyphosate on average Fv/Fm values 28 days after spray for two terrestrial species, a) $G$. canadense and b) $S$. lateriflorum, grown in outdoor microcosms. 

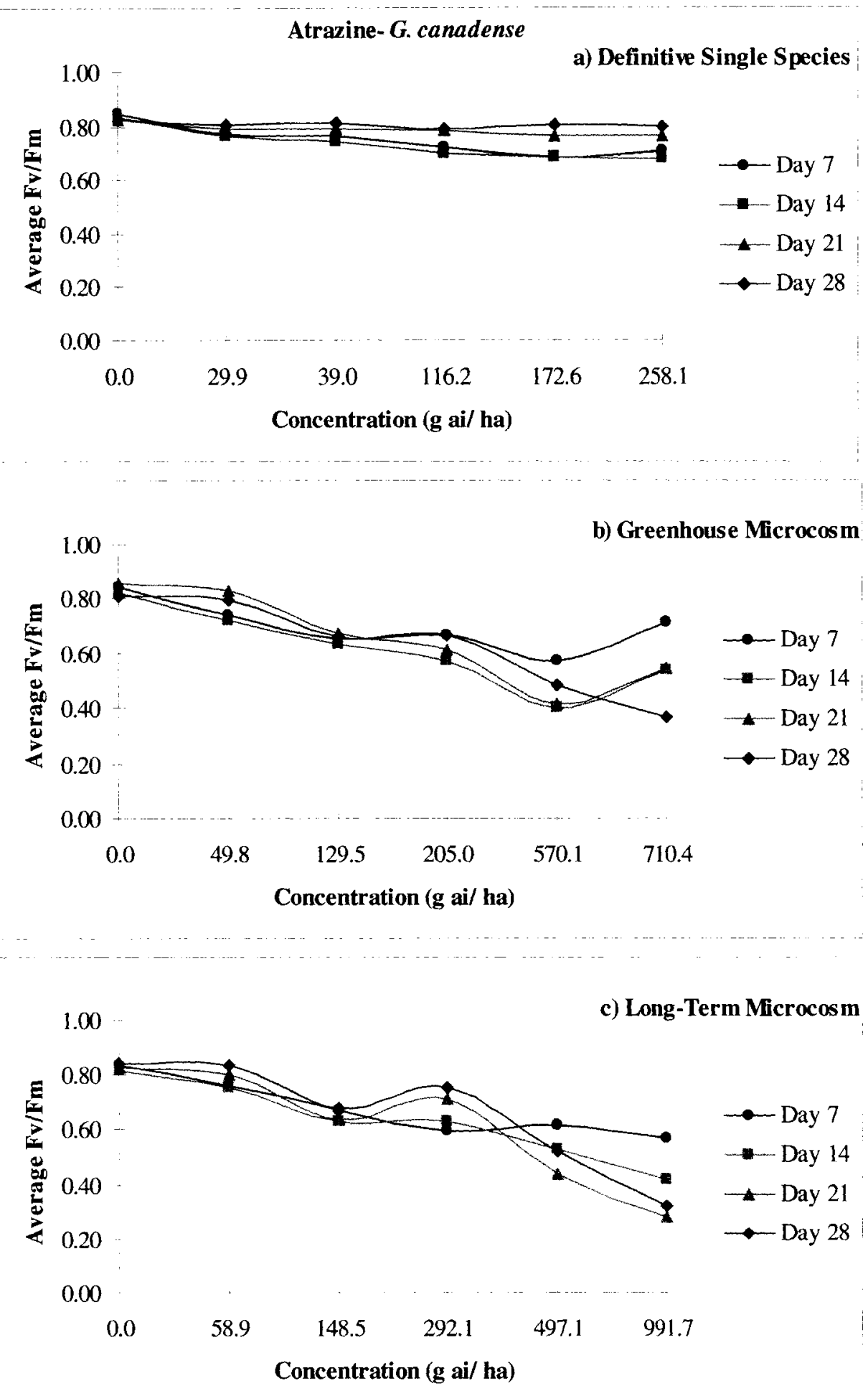

Figure 3.5. The effects of atrazine on average Fv/Fm values 7, 14, 21 and 28 days after spray for the terrestrial species, $G$. canadense, grown a) singly in pots, b) in greenhouse microcosms and $\mathrm{c}$ ) in long-term microcosms. 


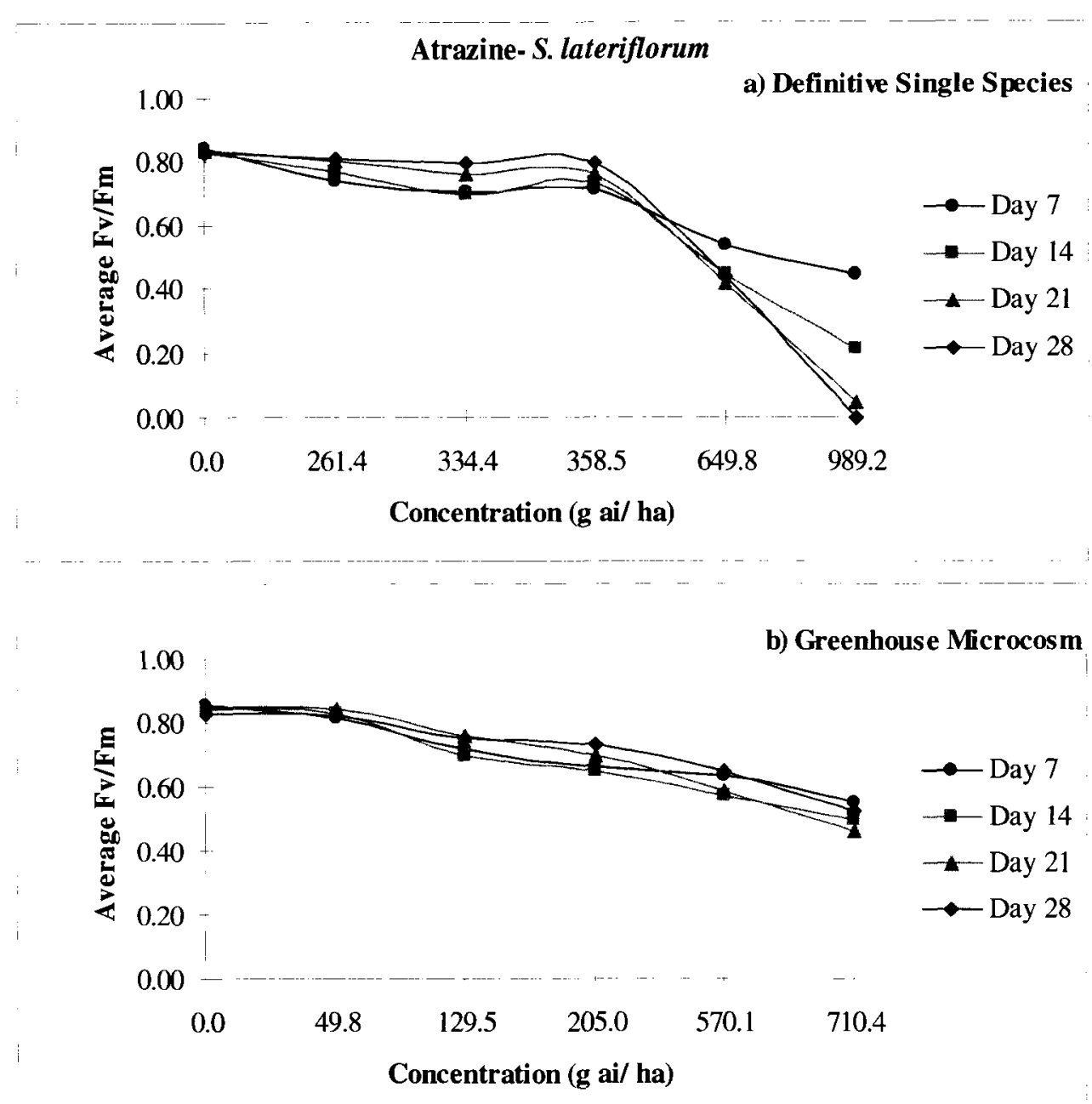

c) Long-Term Microcosm

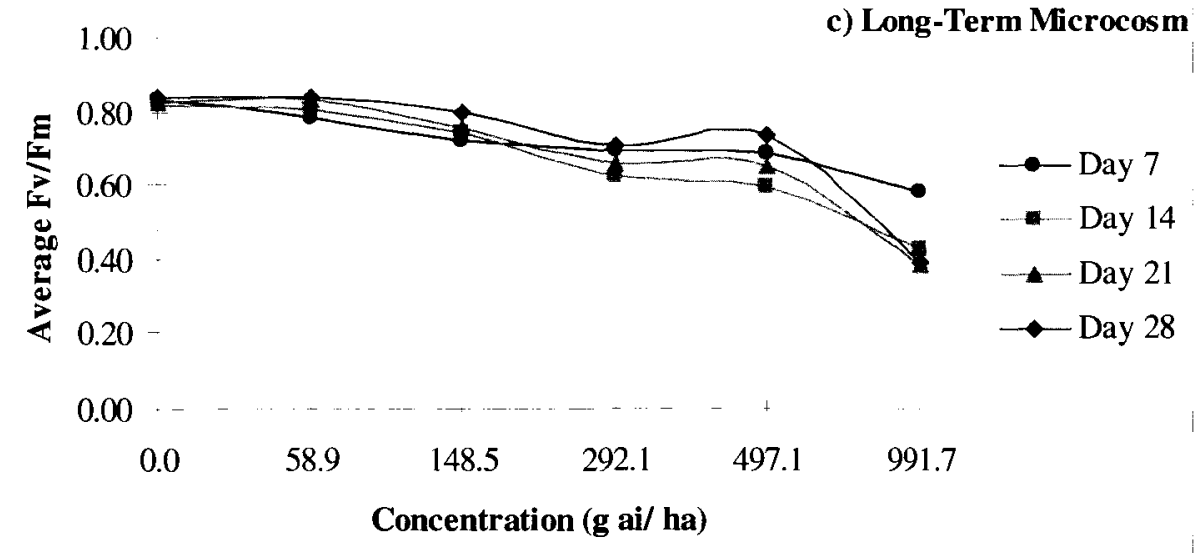

Figure 3.6. The effects of atrazine on average Fv/Fm values 7, 14, 21 and 28 days after spray for the terrestrial species, $S$. lateriflorum, grown a) singly in pots, b) in greenhouse microcosms and $\mathrm{c}$ ) in long-term microcosms. 

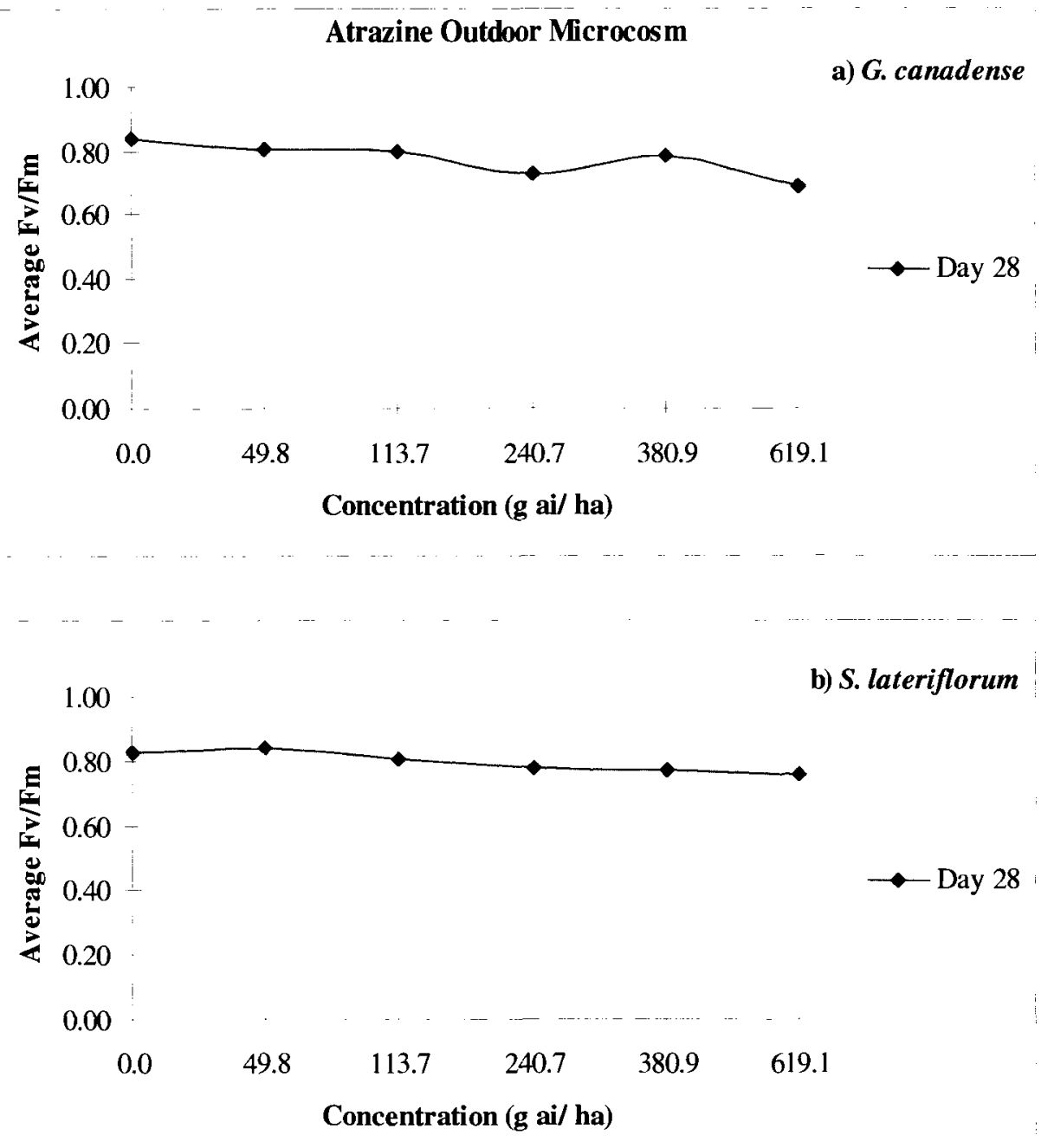

Figure 3.7. The effects of atrazine on average Fv/Fm values 28 days after spray for the terrestrial species, a) G. canadense and b) $S$. lateriflorum, grown in outdoor microcosms. 
Gyphosate- E. maculatum
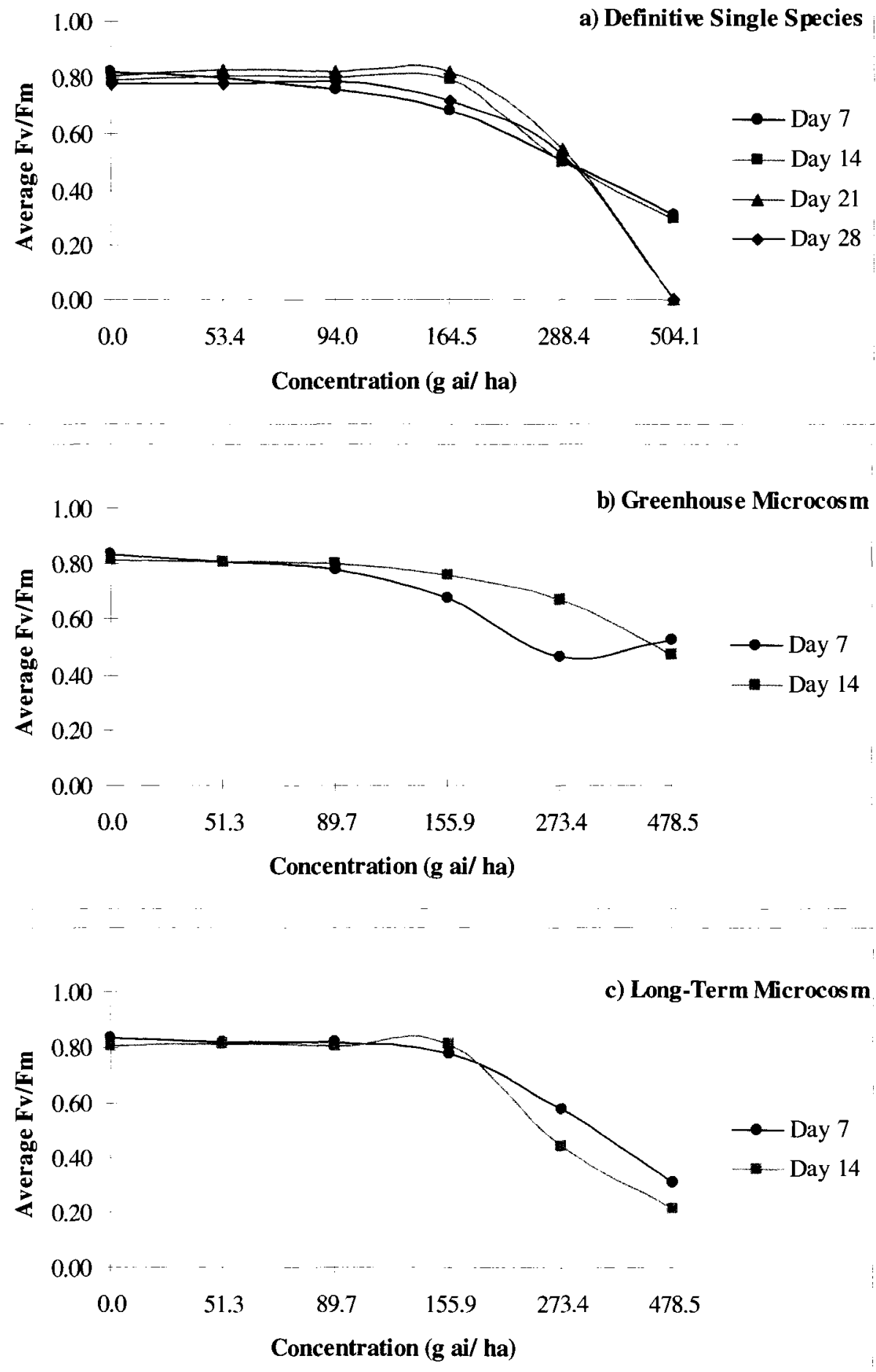

Figure 3.8. The effects of glyphosate on average Fv/Fm values for the wetland species, E. maculatum, grown a) singly in pots, b) in greenhouse microcosms and c) in long-term microcosms. Measurements were taken on days 7 and 14 after spray as well as on days 21 and 28 for the single species test. 
Glyphosate- L. americanus

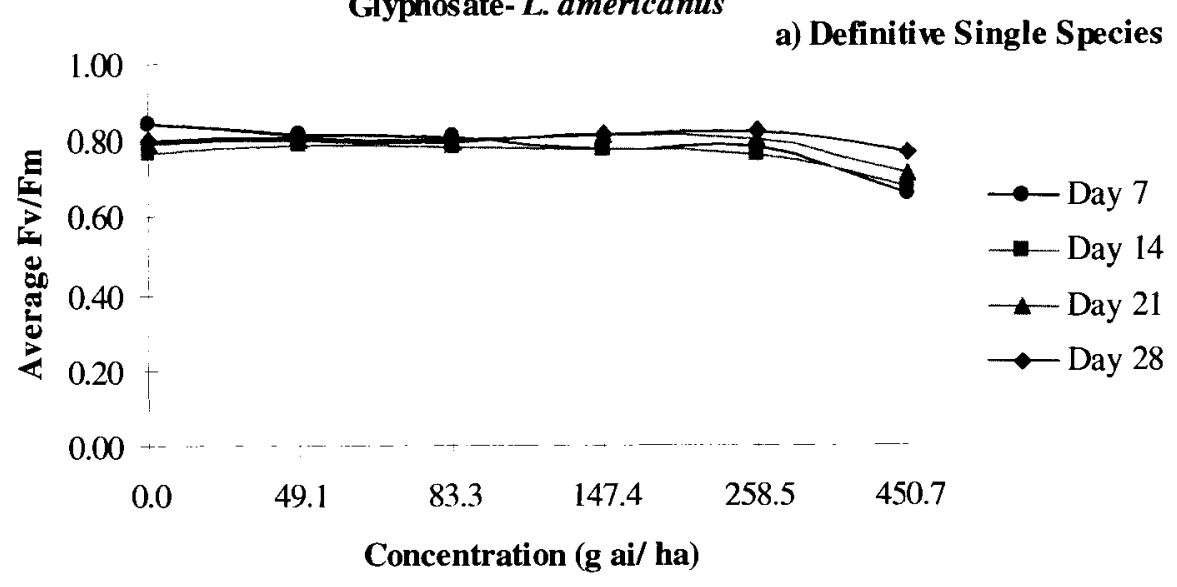

b) Greenhouse Microcosm

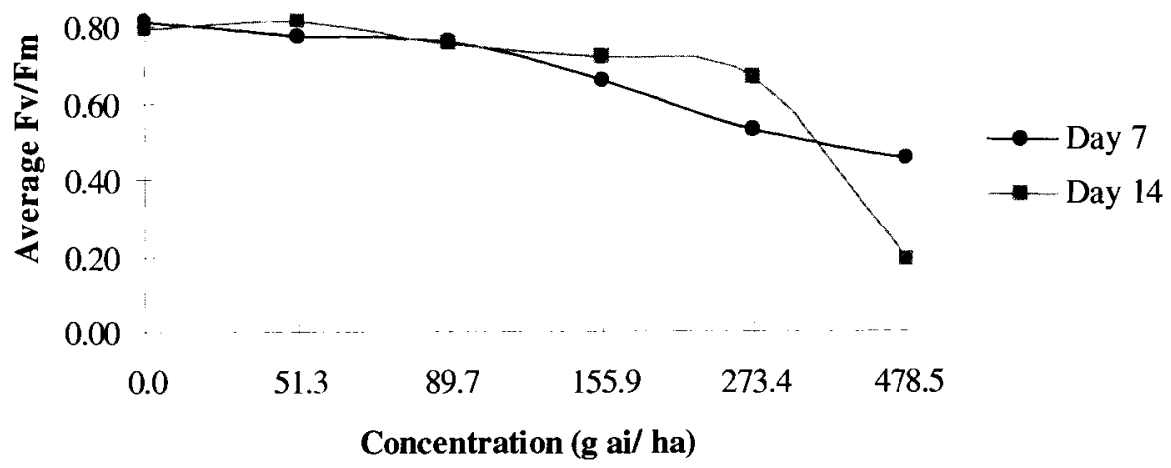

c) Long-Term Microcosm

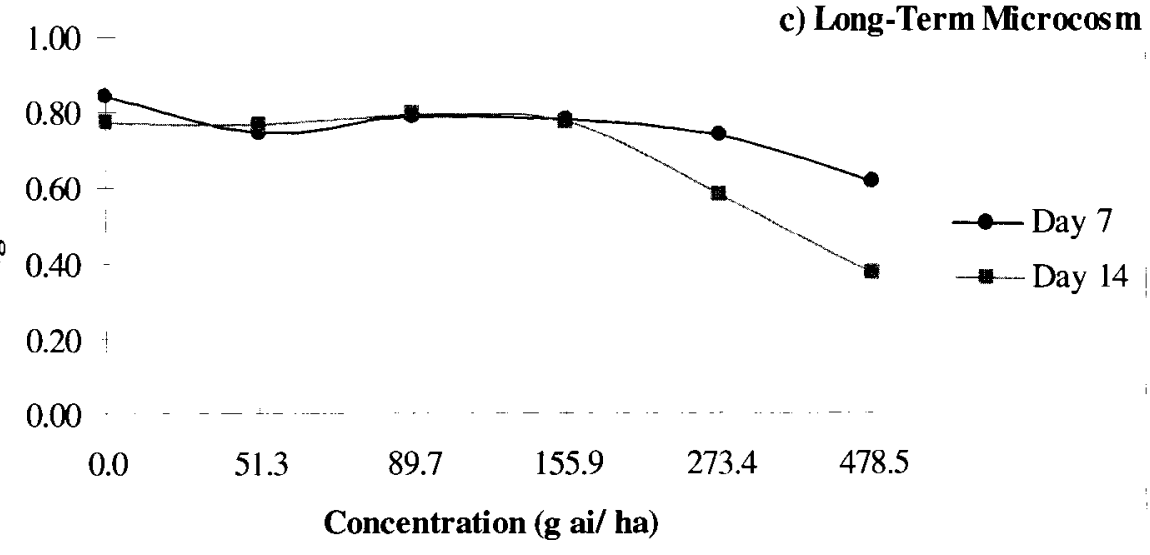

Figure 3.9. The effects of glyphosate on average Fv/Fm values for the wetland species, L. americanus, grown a) singly in pots, b) in greenhouse microcosms and c) in long-term microcosms. Measurements were taken on days 7 and 14 after spray as well as on days 21 and 28 for the single species test. 

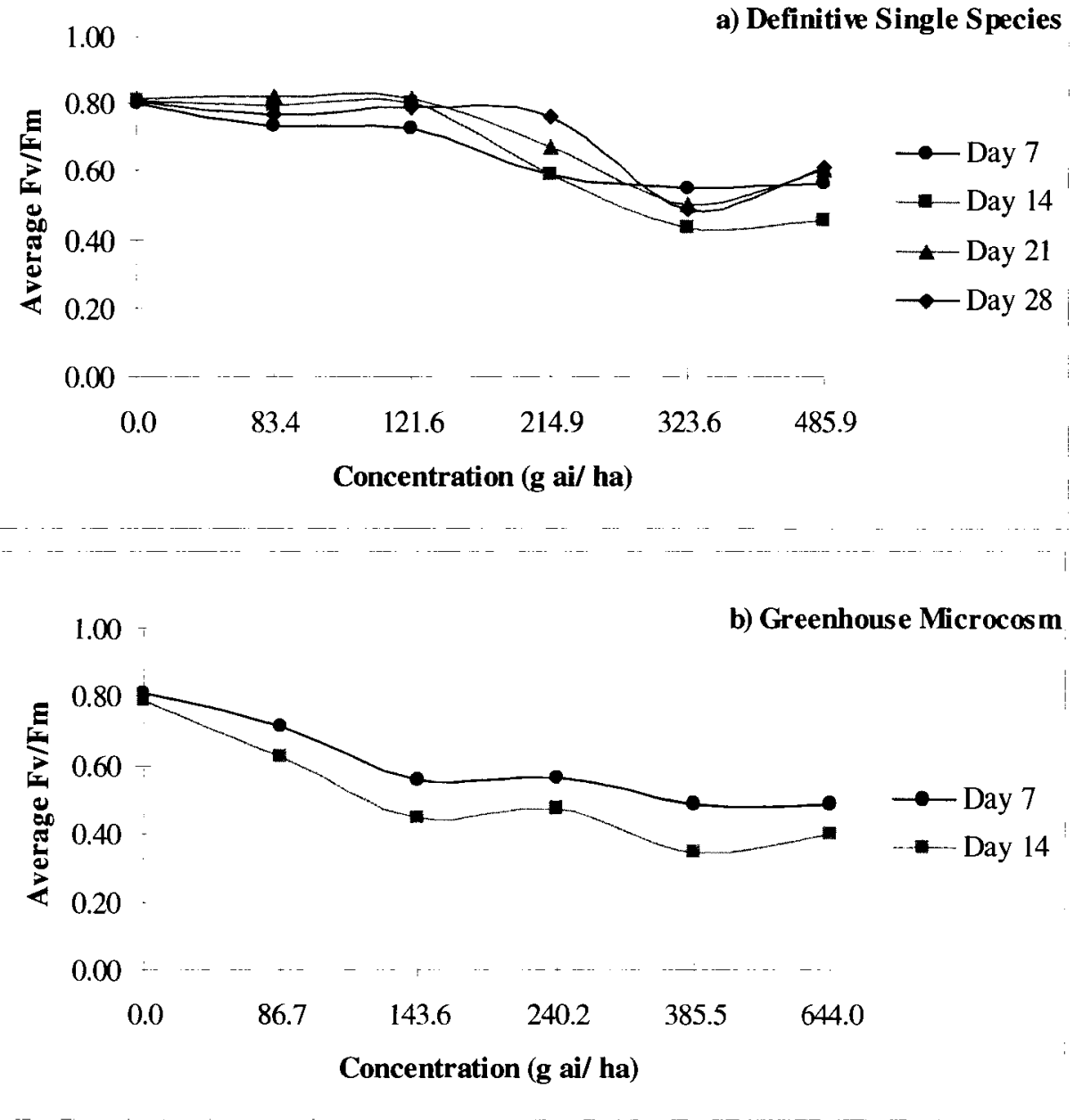

1.00

c) Long-Term Microcosm

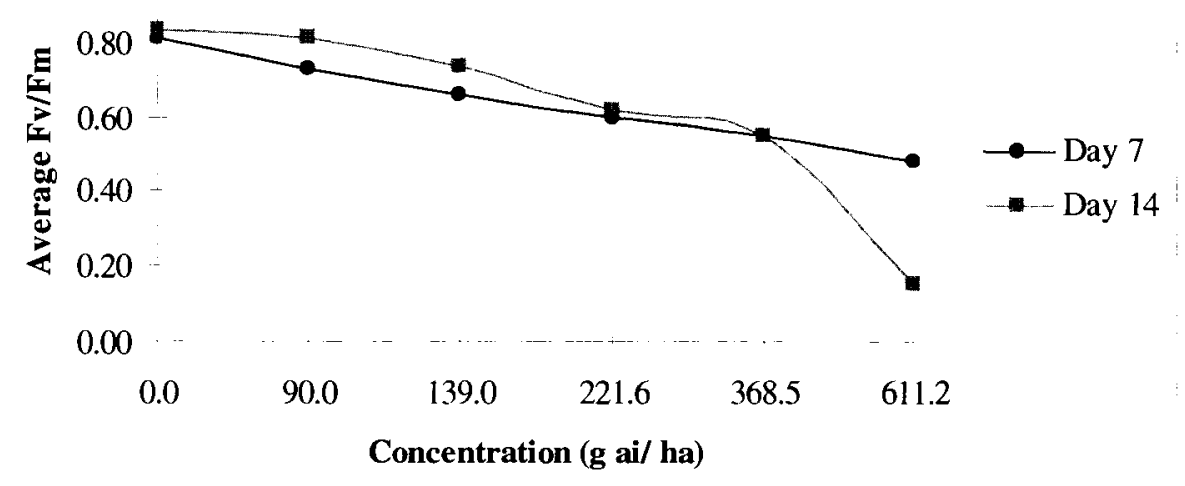

Figure 3.10. The effects of atrazine on average $\mathrm{Fv} / \mathrm{Fm}$ values for the wetland species, $E$. maculatum, grown a) singly in pots, b) in greenhouse microcosms and c) in long-term microcosms. Measurements were taken on days 7 and 14 after spray as well as on days 21 and 28 for the single species test. 
Atrazine- L. americanus

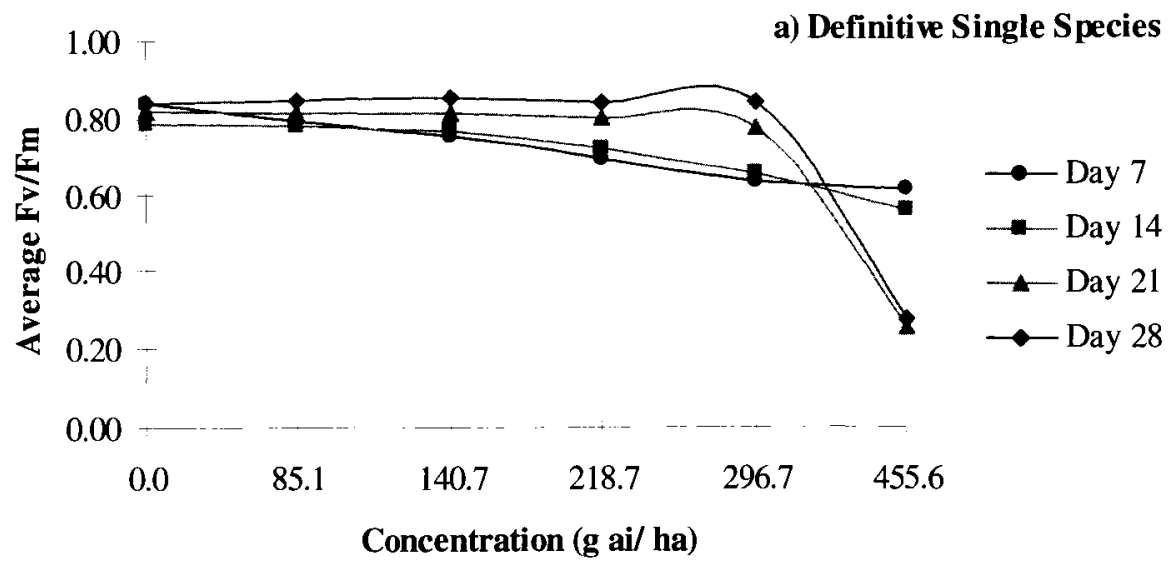

b) Greenhouse Microcosm

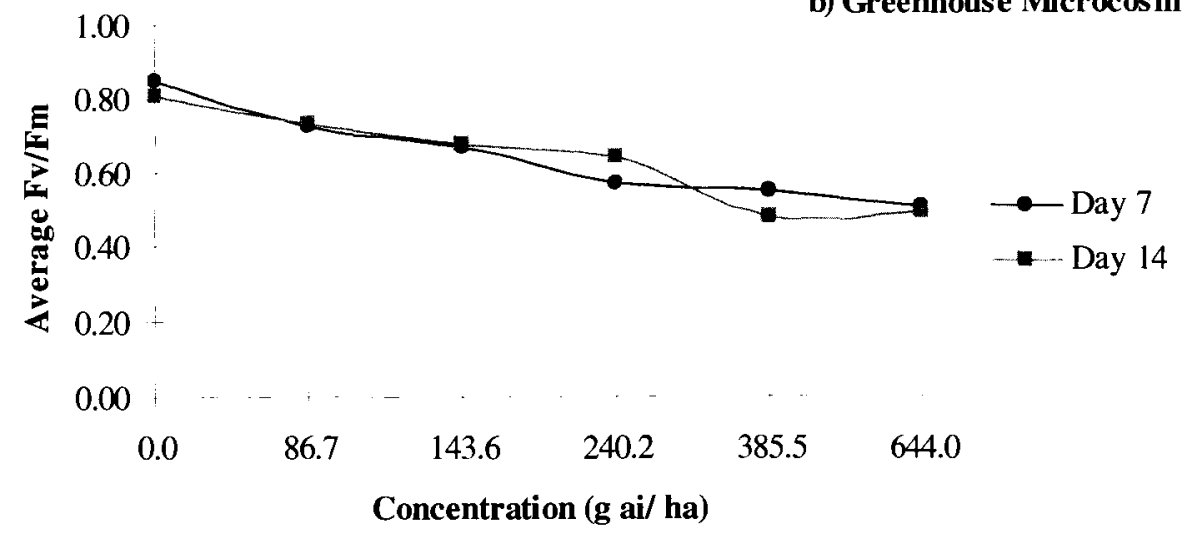

1.00

c) Long-Term Microcosm

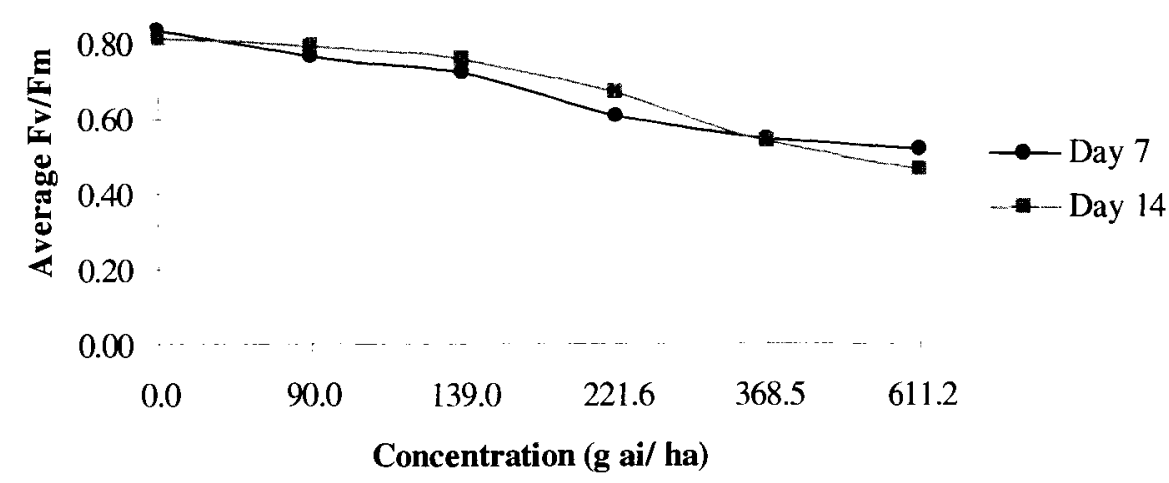

Figure 3.11. The effects of atrazine on average Fv/Fm values for the wetland species, $L$. americanus, grown a) singly in pots, b) in greenhouse microcosms and c) in long-term microcosms. Measurements were taken on days 7 and 14 after spray as well as on days 21 and 28 for the single species test. 


\section{CHAPTER 4:}

\section{STOMATAL CONDUCTANCE AS A POTENTIAL TOOL TO DETECT DIFFERENCES BETWEEN NON-TARGET PLANTS EXPOSED TO GLYPHOSATE OR ATRAZINE AND GROWN UNDER DIFFERENT CONDITIONS}

\subsection{INTRODUCTION}

Porometry is the study of mass transfer of gases through stomata (Monteith, 1980). Stomata are essential in terrestrial plants for maintaining a balance between limiting water loss and uptaking carbon dioxide $\left(\mathrm{CO}_{2}\right)$ from the atmosphere for photosynthesis. During transpiration, water is pulled into mesophyll cell walls where it will then evaporate to sub-stomatal cavities, through stomatal pores, through the leaf boundary layer and finally into the free atmosphere. During photosynthesis, $\mathrm{CO}_{2}$ will follow a similar pathway in the opposite direction (Monteith, 1980; Taiz and Zeiger, 2002). Regulation of water loss and $\mathrm{CO}_{2}$ uptake is largely controlled by guard cell movement which opens and closes the stomatal aperture.

Under conditions where water is not limiting, stomata will be open during the day to maximize photosynthetic rates and closed during the night to minimize water loss (Taiz and Zeiger, 2002). Resistance is a measure of the resistance to water vapour loss through stomata (Bragg, et al., 2004) and its reciprocal, conductance is a measure of conductance of the epidermis to the flux of gases through stomatal openings (Parkinson, 1985). Under daytime conditions when water is abundant, resistance values will be low and conductance values will be high.

Stomatal resistance and conductance can be readily measured with a dynamic diffusion porometer. The theory behind this device has been well established and is 
based on an algorithm derived from gas diffusion theory by Monteith, et al. (1988). This algorithm was expanded upon by Wood (unpublished data, summarized in Bragg, et al., 2004 ) in Delta-T Devices' cycling porometer and is explained below.

A small chamber containing a relative humidity sensor is attached to a leaf's surface and the time it takes for water vapour emitted from a leaf to raise the chamber humidity by a fixed amount is measured. A pump will then blow dry air into the chamber to reduce the chamber's relative humidity $5 \%$ below a set value. The measurement process will be repeated until a stable reading is obtained (typically 3 to 4 cycles). The values obtained are compared to known resistance values obtained through calibration and account for the finite response time of the humidity sensor, the absorption of water vapour by the chamber walls and the difference between the leaf surface and chamber temperatures. Resistance and conductance measurements can be measured in velocity units, $\mathrm{s} \mathrm{cm}^{-1}$ and $\mathrm{cm} \mathrm{s}^{-1}$ respectively, which are based on time and distance. These values are both temperature and pressure dependent and can be converted to units of mol of water vapour per mol of air (e.g. $\mathrm{m}^{2} \mathrm{~s} \mathrm{mmol}{ }^{-1}$ or $\mathrm{mmol} \mathrm{m}^{-2} \mathrm{~s}^{-1}$ ) so that values are independent of pressure and only weakly dependent on temperature. (Monteith, et al., 1988; Bragg, et al., 2004)

Stomata are sensitive to environmental conditions such as light, $\mathrm{CO}_{2}$ concentrations, water stress, pollutants and pathogens. Porometry has been used extensively to assess the effects of environmental variation and stresses on plant performance and has commonly been used to compare the performance of different crop species and varieties (Bragg, et al., 2004). Several studies have found that stomatal conductance is correlated to biomass and/or photosynthetic yield (e.g. Wong, et al., 1979; 
Fischer, et al., 1998; Smith and Moss, 1998; Ferrell, et al., 2003). A few studies have shown that stomatal conductance can be negatively affected by pesticides (e.g. Brecke and Duke, 1980; Zheleva, et al., 1994; Xia, et al., 2006) but only Ivanova, et al. (1999) used multiple doses.

Current pesticide registration guidelines for non-target plants are focused on using biomass measurements (Holst and Ellwanger, 1982; OECD, 1984; EPA, 1996; OECD, 2005) because it is an integrated measure of pesticide damage and does not require specialized equipment. Stomatal conductance measurements have several advantages over biomass measurements in that they are rapid, non-destructive and can be easily measured in the field. Measures of stomatal conductance may provide useful information regarding the effects of pesticides on non-target plants and may be valuable in comparisons of field and laboratory testing.

The main objective of this component of the single species and microcosm experiments was to determine if stomatal conductance could be used as a non-destructive early indicator of damage caused by glyphosate and atrazine. A subsequent objective was to determine if stomatal conductance could be used to detect differences in herbicidal response between plants grown singly in pots and under different microcosm conditions.

\subsection{MATERIALS AND METHODS}

In addition to biomass measurements, stomatal conductance measurements were taken during the course of the definitive single species and microcosm test periods. Refer to Chapter 2.2 for a detailed description of species and herbicide selection, growth and spray conditions as well as the experimental design of the definitive and microcosm tests. 
Stomatal conductance measurements were taken for all definitive single species tests and for the target species in the terrestrial and wetland microcosm tests (A. petiolata, G. canadense, S. lateriflorum and E. maculatum, L. americanus, P. arundinacea respectively). Measurements were taken in units of $\mathrm{mmol} \mathrm{m} \mathrm{m}^{-2} \mathrm{~s}^{-1}$ for all six replicates of each treatment and control. Stomatal conductance was measured on the newest, fully expanded green leaf of each plant using an AP4 cycling diffusion porometer (Delta-T Devices, Cambridge, England). Leaves near the shoot apex were selected at random when it was unclear which leaf was the newest. Measurements were taken for all tests 7 , 14, 21 and 28 days after spray. Measurements were also taken on day 42,56 and 70 for the terrestrial long-term microcosms and on day 42 and 60 for the wetland long-term microcosms. Prior to measurement of stomatal conductance, all pots were well-watered. The porometer was then calibrated once the leaves were fully dry and measurements were taken during the morning when photosynthetic activity was high.

Stomatal conductance values were transformed to percentage of control values by dividing each conductance value by the average control value for the related test. This was done to eliminate variation in the values due to differences in environmental conditions or calibration for a given day.

For both herbicides (glyphosate and atrazine) and habitat types (terrestrial and wetland), each test was analyzed separately to determine if the number of days after spray, species or herbicide concentration affected percent control stomatal conductance. Day and species were included in the analyses as independent fixed categorical predictor variables while the herbicide concentration (log $\mathrm{g}$ ai/ ha) was treated as a log-linear covariate. The analysis of covariance (ANCOVA) assumption of homogeneity of slopes 
was assessed for each model. If the assumption was met, a type III sum of squares ANCOVA was conducted. In cases where the assumption was not met (i.e. there was an interaction between one or more predictor variable and the covariate), the interaction term(s) was included in the model. For each model, the general linear model assumption of normality of residuals and homogeneity of variance was assessed using a ShapiroWilk's test and Levene's test as well as through a visual assessment of the residuals. The dependent variable was transformed to best meet the assumptions using a square root, logarithmic $(\log (y+1))$ or inverse $(-1 / y+1)$ transformation.

Since it is known that stomatal conductance is a measure of the physiological condition of a plant, it was hypothesized that if herbicide concentration affected stomatal conductance, it would be most measurable early in the test period. In addition, stomatal conductance measurements would be most useful as an endpoint, if measurements could be taken soon after herbicidal damage occured. For these reasons, day 7 measurements were chosen to compare percent control stomatal conductance between single species and microcosm tests.

Similarly to the analyses above, test condition (single species, greenhouse, outdoor or long-term microcosm test) and species were independent fixed categorical predictor variables and concentration (log $\mathrm{g}$ ai/ ha) was a quantitative predictor variable. General linear models were constructed as outlined above for each herbicide and habitat type separately. For each model, differences between the main effects of test and species were assessed by calculating the estimated marginal geometric mean at the overall average concentration for an herbicide-habitat combination and performing a Sidak pair- 
wise comparison. Estimated marginal geometric means were also calculated for the interaction between test and species.

The relationship between percent control biomass and percent control stomatal conductance was assessed using nonparametric bivariate correlations for each herbicide and habitat type.

\subsection{RESULTS}

For each individual test, average percent control conductance was plotted against concentration for each day measurements were taken (Figures 4.1-4.14). A brief examination of Tables 4.1 and 4.2 reveals that no single model could explain the effects of days after spray, species and concentration on percent control conductance for all tests.

Herbicide concentration had a highly significant effect on percent control stomatal conductance for all tests (Table 4.1 and 4.2). Concentration was characterized in each model by a very high F-statistic compared to the other variables in the models. Concentration explained far more variation in percent control stomatal conductance values than day, species or interaction variables. In general, stomatal conductance decreased with increasing concentration (Figures 4.1-4.14) suggesting that it is an effective endpoint to assess herbicidal effects.

The number of days after spray also generally had a significant main effect on stomatal conductance values (Tables 4.1 and 4.2). Regardless of concentration effects, the day on which measurements were taken affected stomatal conductance values. Exceptions were in glyphosate terrestrial greenhouse microcosms where values for two of the three species were similar for each day (Figure 4.2); and in terrestrial definitive tests 
(Figure 4.5), terrestrial outdoor tests (Figure 4.8), and wetland long-term tests (Figure 4.14) treated with atrazine, where high variability and interactions obscure differences between days. In general, day 7 percent control conductance values exhibited a clear dose-response pattern. This pattern became more variable and less predictable later in the test period particularly for long-term microcosm tests (Figures 4.3, 4.7, 4.11, 4.14).

Species also significantly affected percent control stomatal conductance for all but two of the tests (Tables 4.1-4.2). Species typically explained the most variation in the dependent variable after concentration as indicated by the F-statistics (Tables 4.1 and 4.2).

In most of the models, there was a least one significant interaction between two variables (Table 4.1 and 4.2). Since the definitive single species tests were conducted during slightly different time periods, it was expected that there would be a significant interaction between species and day because day 7 after spray occurred on different calendar days for each species. This interaction was observed in all single species tests except for the glyphosate terrestrial tests (Table 4.1 and 4.2). An interaction between day and species was also observed in other tests indicating that the temporal change in stomatal conductance is species dependent. An interaction between day and concentration was observed infrequently in the terrestrial tests (except for long-term tests) but commonly in the wetland tests. In most of the terrestrial tests, the relationship between conductance and concentration followed a similar pattern for each day, whereas in almost all of the wetland tests and terrestrial long-term microcosm tests, the response of conductance to concentration differed depending on the day. For example, there was no interaction between greenhouse terrestrial microcosms treated with glyphosate (Figure 
4.2), whereas the response of stomatal conductance in long-term terrestrial microcosms treated with glyphosate depended greatly on the day of measurement (Figure 4.3). Some tests had significant interactions between species and concentration (Tables 4.1 and 4.2) and several had high F-statistics (Figures 4.4, 4.5 and 4.14) indicating that the response of stomatal conductance to herbicides can be quite different between species.

The $\mathrm{R}^{2}$ value of each glyphosate test was higher than that of the corresponding atrazine test and coincided with a higher F-statistics for glyphosate (Tables 4.1 and 4.2). This indicates that stomatal conductance is more affected by glyphosate than atrazine at the concentrations used. A comparison of tests where glyphosate was used with tests where atrazine was used illustrate that a clearer dose-response pattern is typically observed with glyphosate (Figures 4.1-4.14).

A general linear model was constructed for each herbicide and habitat type to determine if a difference existed between single species and microcosm tests, using day 7 stomatal conductance values (Table 4.3). There was no clear indication that percent control stomatal conductance differed between single species and microcosm tests under all circumstances (Table 4.3).

Differences existed between tests types for terrestrial plants treated with atrazine and wetland plants treated with glyphosate (Table 4.3). In both cases, stomatal conductance was lowest for greenhouse microcosms compared to single species tests (Table 4.4). However, the strength of this result was confounded because long-term microcosms (which are replicates of greenhouse microcosms, seven days after spray) did not consistently exhibit the same relationship (Table 4.4). Although the nominal doses were the same between tests, the measured doses were not. Differences between tests 
were also dependent on concentration, indicating that differences in test conditions may be significant at some, but not all points along the dose-response curves (Table 4.3).

When there was a significant difference between species, there was also a significant interaction between concentration and species (Table 4.3). For all four habitat and herbicide combinations, there was a significant interaction between test and species meaning that the response of a species was dependent on the test condition (Table 4.3). At the average concentration for terrestrial tests, stomatal conductance was generally highest for plants grown in outdoor microcosms whereas conductance was typically lowest for plants grown in greenhouse microcosms (Figure 4.15). For the wetland species, percent control stomatal conductance was typically lowest for greenhouse microcosms when treated with glyphosate, whereas conductance was typically lowest for single species tests when treated with atrazine (Figure 4.15). However, these generalizations did not hold true for all species (Figure 4.15).

Concentration clearly had the largest effect on day 7 percent control conductance values compared to test, species or interaction variables as indicated by the large Fstatistics (Table 4.3). Conductance values were quite sensitive to concentration and had a wide response range. The average response at the lowest, middle and highest dose for the different microcosm tests (which had the same range of nominal concentrations) were calculated. Averages were $0.834,0.417,0.153 \%$ for glyphosate terrestrial microcosms and $0.716,0.126,0.084 \%$ for the glyphosate wetland microcosms (Figures $4.2-4.4$ and 4.10-4.11). Average values at the lowest, middle and highest doses were much less affected by atrazine, where averages for atrazine terrestrial microcosms were 0.935 , 
$0.842,0.567 \%$ and $1.130,0.849$ and $0.607 \%$ for the atrazine wetland microcosms (Figures 4.6-4.8 and 4.13-4.14).

Nonparametric bivariate correlations were conducted to relate day 7 stomatal conductance with biomass. The relationship between biomass and stomatal conductance was stronger in the glyphosate tests than in tests using atrazine (Table 4.5). This suggests that while day 7 stomatal conductance is an effective endpoint for both herbicides, it is a better endpoint for glyphosate than atrazine. This relationship can be observed in Figures 4.1-4.14, where the relationship between dose and conductance is much more variable and less pronounced for atrazine treated plants compared to glyphosate treated plants. The relationship between biomass and stomatal conductance for glyphosate treated plants was very strong but not perfect, indicating that additional factors affect stomatal conductance. Day 7 conductance values were generally more strongly correlated to day 28 biomass values compared to day 60 or 70 biomass values. This indicates that day 7 stomatal conductance values are better indicators of short-term rather than long-term effects.

\subsection{DISCUSSION}

The results of this study demonstrated that both atrazine and glyphosate affect stomatal conductance. The effect of concentration on stomatal conductance was consistently large compared to the effects of day, species or test conditions. This suggests that stomatal conductance is an effective endpoint for assessing herbicidal damage. Stomatal conductance was more strongly correlated to biomass for plants treated with glyphosate than for plants treated with atrazine, and models which used 
glyphosate concentration as a predictive variable had higher $\mathrm{R}^{2}$ values. A much wider range of response was observed for glyphosate treated microcosms compared to atrazine treated microcosms.

Previous studies have shown that not all pesticides affect stomatal conductance equally. A study by Xia, et al., (2006) examined the effects of three herbicides, three fungicides and three insecticides on cucumber (Cucumis sativus L.) using net photosynthetic rate, stomatal conductance, intercellular $\mathrm{CO}_{2}$ concentration and several chlorophyll fluorescence parameters. Eight of the nine pesticides, had significant negative effects on stomatal conductance with mean values ranging from $28-94 \%$ of the control mean. Although a significant reduction in stomatal conductance was observed for eight pesticides, the authors attributed overall reductions in photosynthetic rates to both stomatal and non-stomatal factors for five pesticides (paraquat, fluazifop-p-butyl, haloxyfop, imidacloprid and chlorpyrifos), to stomatal factors for two pesticides (cuproxat and abamectin) and to non-stomatal factors for one pesticide (cyazofamid). Similarly, a greenhouse study by Ferrel and Vencill (2004) found that declines in stomatal conductance were highly correlated with a reduction in photosynthetic rate for glyphosate, imazapic and halosulfuron but not for MSMA.

Since glyphosate and atrazine have different modes of action, it is not surprising that their effects on stomatal conductance differ. It has been shown that glyphosate rapidly reduces biomass accumulation, leaf expansion and stomatal aperture without affecting water status (Brecke and Duke, 1980). Stomatal resistance was shown to increase significantly (117\% of control) within an hour of application of glyphosate to bean plants (Phaseolus vulgaris L.) indicating that the herbicide resulted in rapid 
stomatal closure (Brecke and Duke, 1980). Pea plants (Pisum sativum) exposed to atrazine exhibited resistance values twice as high as control plants ten days after exposure (Zheleva, et al., 1994). Atrazine was also found to inhibit photosynthesis and transpiration (Zheleva, et al., 1994). However, the exact mechanisms by which these herbicides affect stomatal conductance are not fully understood and long-term studies of effects on stomatal conductance have not been conducted. A recent study by Messinger, et al. (2006) found that inhibition of electron transport by the herbicide DCMU caused a decrease in stomatal conductance that paralleled a decrease in photosynthesis. Since both atrazine and DCMU are photosystem inhibitiors with similar modes of action, it is possible that atrazine acts on stomatal conductance by a similar mechanism but that its inhibition of stomatal conductance is not as effective as that of glyphosate.

In this study, it has been shown that the number of days since exposure to herbicide generally affects stomatal conductance measurements. A clear dose-response pattern was typically observed early in the test period with the dose-response becoming more variable in the later stages of the test period, particularly in the long-term tests and for atrazine treated plants. This could be a function of both recovery and because stomatal conductance values are reflective of environmental conditions. Recovery of stomatal conductance once a stressor has been removed has been observed in previous studies. A greenhouse study assessing the effects of drought on sunflower plants (Helianthus annus) found that although drought depressed conductance by about $70 \%$, full recovery occurred within 24 hours of rehydration (Cechin, et al., 2006). Wheat (Triticum aestivum) exposed to abscisic acid (ABA), a plant hormone involved in guard cell movement, exhibited increased stomatal resistance that persisted several days before 
values returned to normal (Quarrie and Jones, 1977). The response of plants to herbicides under different environmental conditions will also have an effect on stomatal conductance values.

The results of this study demonstrated that there are some ambiguous differences between single species tests and microcosm community tests. Weak main effect differences in the response to test conditions as well as weak interactions between test and concentration were observed for atrazine terrestrial and glyphosate wetland tests. Despite this ambiguity, results from each herbicide-habitat combination indicated that the response of an individual species was dependent on the test condition. However, differences between greenhouse microcosms and single species tests were not necessarily larger than differences between microcosms grown at slightly different time periods.

Porometry is a versatile tool because stomata are sensitive to a number of different environmental factors such as light, carbon dioxide, pollutants, water stress and pathogens (Bragg, et al., 2004). However, this sensitivity means that the stomatal conductance signal is affected by a number of different factors which can make interpretation difficult. This situation is complicated because stomatal conductance measurements are a snapshot of the physiological status of a plant. It is difficult to determine when the values are reflecting long-term effects on performance versus when they are reflecting short-term environmental conditions. For example, Clarke and Clarke (1996) found that during a 15 min period in which light intensity was lowered as clouds passed over, stomatal conductance was reduced by as much as $25 \%$. Changes in stomatal conductance lagged light intensity by 3-4 minutes, while leaf temperature responded more quickly to light intensity. The magnitude of change caused by variation in light 
intensity was nearly as large as the extremes of genotypic differences between durum wheat cultivars and lines (Clarke and Clarke, 1996). Similarly, a study examining differences between corrected and uncorrected differences in leaf-porometer temperature found that a diurnal variation in this temperature difference resulted in differences in conductance of up to $50 \%$ (Verhoef, 1997). In this study, the effects of microclimatic conditions were partially reduced by using percent control values but variability was still high.

Stomatal conductance of a given species was affected by test condition. While the fraction of leaf space occupied by stomata does not vary between species greatly from $1 \%$ (due to mainly to smaller stomata found in leaves where they are numerous), normal resistance values range from $0.5-4.8 \mathrm{~s} \mathrm{~cm}^{-1}$ for different mesophyte species (Monteith, 1980). A previous study examining the effect of aluminum on stomatal conductance was similar to the current study in that the influence of the chemical was highly variable and species-dependent (Pereira, et al., 2000).

Species may respond differently to a number of factors that may differ between test conditions. Several studies have compared stomatal conductance under field and greenhouse conditions. A study by Davies (1977) found that stomata in plants grown under field conditions were less sensitive compared to those in plants grown in a growth chamber or greenhouse. Patterson, et al. (1977), found that plants grown outdoors, where light intensity was three times higher than in growth chambers, had more chlorophyll per unit area, thicker leaves and more stomata than in growth chambers. Spectral quality has also been found to affect diurnal patterns of stomatal conductance (Kim, et al., 2004). Exposure to the hormone abscisic acid and water stress reduced the number of stomata 
per leaf and increased the production of trichomes (Quarrie and Jones, 1977). Interspecific interactions between species could also affect the response of plants to herbicides and complicate interpretation of causal effects. Asymmetric competition has been found to reduce stomatal conductance for one species but not for another species in a field study conducted with natural vegetation (Silletti, et al., 2004). This interaction was also influenced by the addition of fertilizer (Silletti, et al., 2004).

The sensitivity of stomatal conductance to environmental conditions highlight the importance of test conditions and suggest why single species tests may oversimplify and mask interactions that exist under natural conditions. The results of this study concur with the conclusions of Davies in 1977, that the effect of growth conditions may not be uniform for all species and care should be taken in making comparisons between species grown in different conditions.

Results of this study indicated that stomatal conductance can be a rapid nondestructive early indicator of toxicity of glyphosate and atrazine. Stomatal conductance is a much more effective endpoint for glyphosate compared to atrazine because it is more strongly correlated to biomass and follows a wider range of response. Average values for the range of response corresponded very well with the intended effect of $20-80 \%$ for the glyphosate tests with an effect range of $17-85 \%$ for terrestrial microcosms and $28 \%-92 \%$ for wetland microcosms. Stomatal conductance was a less sensitive endpoint for atrazine with effect ranges of $7-43 \%$ for terrestrial microcosms and a hormetic effect of positive $13 \%$ to a decrease of $39 \%$ for wetland microcosms.

While previous research has not evaluated the use of conductance as a toxicity endpoint, several studies have shown that changes in stomatal conductance are often 
proportional to changes in carbon assimulation (Wong, et al., 1979; Ferrell, et al., 2003; Ferrell and Vencill, 2004). Reductions in stomatal conductance have also been shown to be accompanied by changes in mortality and biomass, and to be a non-destructive technique to determine differential flood tolerance (Smith and Moss, 1998). Stomatal conductance may be particularly useful in multi-species studies because it has been found to be useful in assessing changes in competitive ability (Ferrell, et al., 2003; Ferrell and Vencill, 2004). However, stomatal conductance measures should be used in conjunction with another parameter because small perturbations in environmental conditions can lead to large changes in conductance values.

\subsection{CONCLUSIONS}

Stomatal conductance is affected by both glyphosate and atrazine in a doseresponse pattern but is a much more effective endpoint for plants treated with glyphosate than with atrazine. Stomatal conductance values are highly sensitive to a range of environmental parameters and thus contain more information than simply a dose-effect. Individual species may respond differently to different test conditions when exposed to herbicides. The response of multiple species to a particular test condition may differ, reducing the ability of a single test to accurately predict risk in other environmental conditions. Stomatal conductance is a useful non-destructive early indicator of herbicidal damage. However, appropriate comparisons with controls, an understanding of the effect of environmental conditions, and another parameter of physiological health are needed to quantify the effect. 
Table 4.1 Summary of type III sum of squares general linear models assessing the effects of day, species and herbicide concentration on percent control stomatal conductance for terrestrial plants treated with glyphosate and atrazine under different test conditions. Stomatal conductance measurements were taken 7, 14,21 and 28 days after spray for all tests as well as on days 42,56 and 70 for long-term microcosm tests. $(\mathrm{F}=\mathrm{F}$ statistic, $\mathrm{df}=$ variable and error degrees of freedom, $\mathrm{P}=$ significance at $<\mathbf{0 . 0 5})$

\begin{tabular}{|c|c|c|c|c|c|c|c|c|}
\hline & \multicolumn{4}{|c|}{ Glyphosate } & \multicolumn{4}{|c|}{ Atrazine } \\
\hline Model & $\begin{array}{l}\text { Definitive } \\
\text { Single } \\
\text { Species }\end{array}$ & $\begin{array}{l}\text { Greenhouse } \\
\text { Microcosms }\end{array}$ & $\begin{array}{l}\text { Long-term } \\
\text { Microcosms }\end{array}$ & $\begin{array}{l}\text { Outdoor } \\
\text { Microcosms }\end{array}$ & $\begin{array}{l}\text { Definitive } \\
\text { Single } \\
\text { Species }\end{array}$ & $\begin{array}{l}\text { Greenhouse } \\
\text { Microcosms }\end{array}$ & $\begin{array}{l}\text { Long-term } \\
\text { Microcosms }\end{array}$ & $\begin{array}{l}\text { Outdoor } \\
\text { Microcosms }\end{array}$ \\
\hline $\begin{array}{l}\text { Dependent } \\
\text { Variable } \\
\text { Transformation }\end{array}$ & $\sqrt{y}$ & $-1 / y+1$ & $-1 / y+1$ & $-1 / y+1$ & $\log (y+1)$ & $\log (y+1)$ & $\log (y+1)$ & $\log (y+1)$ \\
\hline Day & $\begin{array}{l}F=3.625 \\
d f=3,347 \\
P=0.013\end{array}$ & $\begin{array}{l}\mathrm{F}=0.794 \\
\mathrm{df}=3,347 \\
\mathrm{P}=0.498\end{array}$ & $\begin{array}{l}\mathrm{F}=5.127 \\
\mathrm{df}=6,600 \\
\mathbf{P}<\mathbf{0 . 0 0 1}\end{array}$ & $\begin{array}{l}F=4.404 \\
\mathrm{df}=3,345 \\
\mathbf{P}=\mathbf{0 . 0 0 5}\end{array}$ & $\begin{array}{l}F=1.081 \\
d f=3,336 \\
P=0.357\end{array}$ & $\begin{array}{l}\mathrm{F}=11.918 \\
\mathrm{df}=3,345 \\
\mathbf{P}<\mathbf{0 . 0 0 1}\end{array}$ & $\begin{array}{l}\mathrm{F}=4.330 \\
\mathrm{df}=6,600 \\
\mathrm{P}<\mathbf{0 . 0 0 1}\end{array}$ & $\begin{array}{l}\mathrm{F}=0.277 \\
\mathrm{df}=3,336 \\
P=0.842\end{array}$ \\
\hline Species & $\begin{array}{l}\mathrm{F}=10.535 \\
\mathrm{df}=2,347 \\
\mathbf{P}<\mathbf{0 . 0 0 1}\end{array}$ & $\begin{array}{l}\mathrm{F}=0.681 \\
\mathrm{df}=2,347 \\
\mathrm{P}=0.507\end{array}$ & $\begin{array}{l}\mathrm{F}=7.389 \\
\mathrm{df}=2,600 \\
\mathbf{P}=\mathbf{0 . 0 0 1}\end{array}$ & $\begin{array}{l}\mathrm{F}=33.273 \\
\mathrm{df}=2,345 \\
\mathrm{P}<\mathbf{0 . 0 0 1}\end{array}$ & $\begin{array}{l}\mathrm{F}=40.528 \\
\mathrm{df}=2,336 \\
\mathbf{P}<\mathbf{0 . 0 0 1}\end{array}$ & $\begin{array}{l}F=3.034 \\
d f=2,345 \\
P=\mathbf{0 . 0 4 9}\end{array}$ & $\begin{array}{l}F=1.980 \\
d f=2,600 \\
P=0.139\end{array}$ & $\begin{array}{l}\mathrm{F}=4.610 \\
\mathrm{df}=2,336 \\
\mathbf{P}=\mathbf{0 . 0 1 1}\end{array}$ \\
\hline Concentration & $\begin{array}{l}F=162.964 \\
\mathrm{df}=1,347 \\
P<\mathbf{0 . 0 0 1}\end{array}$ & $\begin{array}{l}\mathrm{F}=416.520 \\
\mathrm{df}=1,347 \\
\mathrm{P}<\mathbf{0 . 0 0 1}\end{array}$ & $\begin{array}{l}F=513.538 \\
\mathrm{df}=1,600 \\
\mathrm{P}<\mathbf{0 . 0 0 1}\end{array}$ & $\begin{array}{l}\mathrm{F}=295.431 \\
\mathrm{df}=1,345 \\
\mathbf{P}<\mathbf{0 . 0 0 1}\end{array}$ & $\begin{array}{l}\mathrm{F}=78.111 \\
\mathrm{df}=1,336 \\
\mathrm{P}<\mathbf{0 . 0 0 1}\end{array}$ & $\begin{array}{l}\mathrm{F}=40.093 \\
\mathrm{df}=1,345 \\
\mathrm{P}<\mathbf{0 . 0 0 1}\end{array}$ & $\begin{array}{l}\mathrm{F}=6.929 \\
\mathrm{df}=1,600 \\
\mathrm{P}=\mathbf{0 . 0 0 9}\end{array}$ & $\begin{array}{l}\mathrm{F}=23.952 \\
\mathrm{df}=1,336 \\
\mathrm{P}<\mathbf{0 . 0 0 1}\end{array}$ \\
\hline Day* Species & $\begin{array}{l}\mathrm{F}=2.120 \\
\mathrm{df}=6,347 \\
\mathrm{P}=0.051\end{array}$ & $\begin{array}{l}F=2.344 \\
d f=6,347 \\
P=0.031\end{array}$ & $\begin{array}{l}\mathrm{F}=1.600 \\
\mathrm{df}=12,600 \\
\mathrm{P}=0.087\end{array}$ & $\begin{array}{l}F=3.388 \\
d f=6,345 \\
P=0.003\end{array}$ & $\begin{array}{l}\mathrm{F}=2.483 \\
\mathrm{df}=6,336 \\
\mathbf{P}=\mathbf{0 . 0 2 3}\end{array}$ & $\begin{array}{l}\mathrm{F}=6.849 \\
\mathrm{df}=6,345 \\
\mathbf{P}<\mathbf{0 . 0 0 1}\end{array}$ & $\begin{array}{l}F=1.759 \\
d f=12,600 \\
P=0.052\end{array}$ & $\begin{array}{l}F=5.188 \\
d f=6,336 \\
P<0.001\end{array}$ \\
\hline $\begin{array}{l}\text { Day* } \\
\text { Concentration }\end{array}$ & N/A & N/A & $\begin{array}{l}\mathrm{F}=3.991 \\
\mathrm{df}=6,600 \\
\mathrm{P}=\mathbf{0 . 0 0 1}\end{array}$ & N/A & N/A & N/A & $\begin{array}{l}\mathrm{F}=5.300 \\
\mathrm{df}=6,600 \\
\mathbf{P}<\mathbf{0 . 0 0 1}\end{array}$ & N/A \\
\hline $\begin{array}{l}\text { Species* } \\
\text { Concentration }\end{array}$ & N/A & N/A & $\begin{array}{l}F=7.470 \\
\mathrm{df}=2,600 \\
P=\mathbf{0 . 0 0 1}\end{array}$ & $\begin{array}{l}\mathrm{F}=34.094 \\
\mathrm{df}=2, \mathbf{3 4 5} \\
\mathrm{P}<\mathbf{0 . 0 0 1}\end{array}$ & $\begin{array}{l}\mathrm{F}=43.139 \\
\mathrm{df}=2,336 \\
\mathrm{P}<\mathbf{0 . 0 0 1}\end{array}$ & $\begin{array}{l}\mathrm{F}=3.960 \\
\mathrm{df}=2,345 \\
\mathrm{P}=\mathbf{0 . 0 2 0}\end{array}$ & $\begin{array}{l}F=3.100 \\
\mathrm{df}=2,600 \\
P=\mathbf{0 . 0 4 6}\end{array}$ & $\begin{array}{l}F=4.961 \\
\mathrm{df}=2,336 \\
P=\mathbf{0 . 0 0 8}\end{array}$ \\
\hline $\begin{array}{l}\text { Day* Species * } \\
\text { Concentration }\end{array}$ & N/A & N/A & N/A & N/A & $\begin{array}{l}\mathrm{F}=2.067 \\
\mathrm{df}=9,336 \\
\mathbf{P}=\mathbf{0 . 0 3 2}\end{array}$ & N/A & N/A & $\begin{array}{l}\mathrm{F}=4.064 \\
\mathrm{df}=9,336 \\
\mathbf{P}<\mathbf{0 . 0 0 1}\end{array}$ \\
\hline R-Squared & 0.410 & 0.556 & 0.525 & 0.537 & 0.391 & 0.272 & 0.132 & 0.331 \\
\hline
\end{tabular}


Table 4.2 Summary of type III sum of squares general linear models assessing the effects of day, species and herbicide concentration on percent control stomatal conductance for wetland plants treated with glyphosate and atrazine under different test conditions. Stomatal conductance measurements were taken 7, 14, 21 and 28 days after spray for all tests as well as on days 42 , and 60 for longterm microcosm tests. ( $F=F$ statistic, $d f=$ variable and error degrees of freedom, $\mathrm{P}=$ significance at $<\mathbf{0 . 0 5})$

\begin{tabular}{|c|c|c|c|c|c|c|}
\hline \multirow[b]{2}{*}{ Model } & \multicolumn{3}{|c|}{ Glyphosate } & \multicolumn{3}{|c|}{ Atrazine } \\
\hline & $\begin{array}{l}\text { Definitive Single } \\
\text { Species }\end{array}$ & $\begin{array}{l}\text { Greenhouse } \\
\text { Microcosms }\end{array}$ & $\begin{array}{l}\text { Long-term } \\
\text { Microcosms }\end{array}$ & $\begin{array}{l}\text { Definitive Single } \\
\text { Species }\end{array}$ & $\begin{array}{l}\text { Greenhouse } \\
\text { Microcosms }\end{array}$ & $\begin{array}{l}\text { Long-term } \\
\text { Microcosms }\end{array}$ \\
\hline $\begin{array}{l}\text { Dependent Variable } \\
\text { Transformation }\end{array}$ & $\sqrt{y}$ & $\sqrt{y}$ & $\sqrt{y}$ & $\log (y+1)$ & $-1 / y+1$ & $-1 / y+1$ \\
\hline Day & $\begin{array}{l}\mathrm{F}=10.688 \\
\mathrm{df}=3,342 \\
\mathrm{P}<\mathbf{0 . 0 0 1}\end{array}$ & $\begin{array}{l}F=5.785 \\
d f=3,342 \\
P=0.001\end{array}$ & $\begin{array}{l}\mathrm{F}=6.079 \\
\mathrm{df}=5,516 \\
\mathbf{P}<\mathbf{0 . 0 0 1}\end{array}$ & $\begin{array}{l}F=11.341 \\
\mathrm{df}=3,347 \\
P<\mathbf{0 . 0 0 1}\end{array}$ & $\begin{array}{l}F=3.085 \\
d f=3,342 \\
P=0.027\end{array}$ & $\begin{array}{l}F=2.081 \\
d f=5,514 \\
P=0.066\end{array}$ \\
\hline Species & $\begin{array}{l}\mathrm{F}=5.629 \\
\mathrm{df}=2,342 \\
\mathrm{P}=\mathbf{0 . 0 0 4}\end{array}$ & $\begin{array}{l}\mathrm{F}=18.424 \\
\mathrm{df}=2,342 \\
\mathrm{P}<\mathbf{0 . 0 0 1}\end{array}$ & $\begin{array}{l}\mathrm{F}=13.713 \\
\mathrm{df}=2,516 \\
\mathbf{P}<\mathbf{0 . 0 0 1}\end{array}$ & $\begin{array}{l}F=19.754 \\
\mathrm{df}=2,347 \\
\mathrm{P}<\mathbf{0 . 0 0 1}\end{array}$ & $\begin{array}{l}\mathrm{F}=16.842 \\
\mathrm{df}=2,342 \\
\mathrm{P}<\mathbf{0 . 0 0 1}\end{array}$ & $\begin{array}{l}F=42.198 \\
\mathrm{df}=2,514 \\
\mathbf{P}<\mathbf{0 . 0 0 1}\end{array}$ \\
\hline Concentration & $\begin{array}{l}\mathrm{F}=310.130 \\
\mathrm{df}=1,342 \\
\mathrm{P}<\mathbf{0 . 0 0 1}\end{array}$ & $\begin{array}{l}\mathrm{F}=434.745 \\
\mathrm{df}=1,342 \\
\mathbf{P}<\mathbf{0 . 0 0 1}\end{array}$ & $\begin{array}{l}\mathrm{F}=657.531 \\
\mathrm{df}=1,516 \\
\mathbf{P}<\mathbf{0 . 0 0 1}\end{array}$ & $\begin{array}{l}\mathrm{F}=50.873 \\
\mathrm{df}=1,347 \\
\mathbf{P}<\mathbf{0 . 0 0 1}\end{array}$ & $\begin{array}{l}\mathrm{F}=167.991 \\
\mathrm{df}=1,342 \\
\mathbf{P}<\mathbf{0 . 0 0 1}\end{array}$ & $\begin{array}{l}\mathrm{F}=96.265 \\
\mathrm{df}=1,514 \\
\mathbf{P}<\mathbf{0 . 0 0 1}\end{array}$ \\
\hline Day* Species & $\begin{array}{l}\mathrm{F}=4.246 \\
\mathrm{df}=6,342 \\
\mathrm{P}<\mathbf{0 . 0 0 1}\end{array}$ & $\begin{array}{l}\mathrm{F}=1.128 \\
\mathrm{df}=6,342 \\
\mathrm{P}=0.345\end{array}$ & $\begin{array}{l}F=4.080 \\
d f=10,516 \\
P<0.001\end{array}$ & $\begin{array}{l}F=14.004 \\
d f=6,347 \\
P<0.001\end{array}$ & $\begin{array}{l}\mathrm{F}=3.589 \\
\mathrm{df}=6,342 \\
\mathbf{P}=\mathbf{0 . 0 0 2}\end{array}$ & $\begin{array}{l}\mathrm{F}=1.821 \\
\mathrm{df}=10,514 \\
\mathrm{P}=0.054\end{array}$ \\
\hline Day* Concentration & $\begin{array}{l}\mathrm{F}=7.957 \\
\mathrm{df}=3,342 \\
\mathbf{P}<\mathbf{0 . 0 0 1}\end{array}$ & $\begin{array}{l}F=6.139 \\
\mathrm{df}=3,342 \\
P<\mathbf{0 . 0 0 1}\end{array}$ & $\begin{array}{l}F=5.126 \\
d f=5,516 \\
P<0.001\end{array}$ & N/A & $\begin{array}{l}F=3.476 \\
d f=3,342 \\
P=\mathbf{0 . 0 1 6}\end{array}$ & $\begin{array}{l}F=2.259 \\
d f=5,514 \\
P=0.047\end{array}$ \\
\hline Species* Concentration & $\begin{array}{l}\mathrm{F}=3.552 \\
\mathrm{df}=2,342 \\
\mathbf{P}=\mathbf{0 . 0 3 0}\end{array}$ & $\begin{array}{l}F=13.471 \\
\mathrm{df}=2,342 \\
\mathrm{P}<\mathbf{0 . 0 0 1}\end{array}$ & N/A & N/A & $\begin{array}{l}\mathrm{F}=17.471 \\
\mathrm{df}=2,342 \\
\mathbf{P}<\mathbf{0 . 0 0 1}\end{array}$ & $\begin{array}{l}\mathrm{F}=49.848 \\
\mathrm{df}=2,514 \\
\mathrm{P}<\mathbf{0 . 0 0 1}\end{array}$ \\
\hline $\begin{array}{l}\text { Day* Species* } \\
\text { Concentration }\end{array}$ & N/A & N/A & N/A & N/A & N/A & N/A \\
\hline R-Squared & 0.630 & 0.611 & 0.598 & 0.373 & 0.461 & 0.354 \\
\hline
\end{tabular}


Table 4.3. Summary of type III sum of squares general linear models assessing the effects of test condition, species and herbicide concentration on percent control conductance seven days after spray. Terrestrial plants were grown under four test conditions (single species tests, greenhouse microcosm tests, outdoor microcosm tests and long-term microcosm tests) while wetland plants were grown under three test conditions (single species tests, greenhouse microcosm tests and long-term microcosm tests). ( $F=F$ statistic, $\mathrm{df}=$ independent variable and error degrees of freedom, $\mathrm{P}=$ significance at $<\mathbf{0 . 0 5}$ ).

\begin{tabular}{|c|c|c|c|c|}
\hline Model & $\begin{array}{l}\text { Glyphosate } \\
\text { Terrestrial } \\
\text { Tests } \\
\end{array}$ & $\begin{array}{l}\text { Atrazine } \\
\text { Terrestrial } \\
\text { Tests } \\
\end{array}$ & $\begin{array}{l}\text { Glyphosate } \\
\text { Wetland Tests }\end{array}$ & $\begin{array}{l}\text { Atrazine } \\
\text { Wetland Tests }\end{array}$ \\
\hline $\begin{array}{l}\text { Dependent Variable } \\
\text { Transformation }\end{array}$ & $-1 / y+1$ & $\sqrt{y}$ & $-1 / y+1$ & $\log (y+1)$ \\
\hline Test & $\begin{array}{l}\mathrm{F}=1.243 \\
\mathrm{df}=3,347 \\
\mathrm{P}=0.294\end{array}$ & $\begin{array}{l}\mathrm{F}=3.023 \\
\mathrm{df}=3,336 \\
\mathbf{P}=\mathbf{0 . 0 3 0}\end{array}$ & $\begin{array}{l}\mathrm{F}=3.547 \\
\mathrm{df}=2,256 \\
\mathbf{P}=\mathbf{0 . 0 3 0}\end{array}$ & $\begin{array}{l}\mathrm{F}=0.716 \\
\mathrm{df}=2,252 \\
P=0.490\end{array}$ \\
\hline Species & $\begin{array}{l}\mathrm{F}=2.270 \\
\mathrm{df}=2,347 \\
\mathrm{P}=0.105\end{array}$ & $\begin{array}{l}\mathrm{F}=8.018 \\
\mathrm{df}=2,336 \\
\mathbf{P}<\mathbf{0 . 0 0 1}\end{array}$ & $\begin{array}{l}\mathrm{F}=5.855 \\
\mathrm{df}=2,256 \\
\mathbf{P}=\mathbf{0 . 0 0 3}\end{array}$ & $\begin{array}{l}\mathrm{F}=12.746 \\
\mathrm{df}=2,252 \\
\mathbf{P}<\mathbf{0 . 0 0 1}\end{array}$ \\
\hline Concentration & $\begin{array}{l}F=226.757 \\
d f=1,347 \\
P<\mathbf{0 . 0 0 1}\end{array}$ & $\begin{array}{l}\mathrm{F}=60.808 \\
\mathrm{df}=1,336 \\
\mathbf{P}<\mathbf{0 . 0 0 1}\end{array}$ & $\begin{array}{l}\mathrm{F}=153.931 \\
\mathrm{df}=1,256 \\
\mathbf{P}<\mathbf{0 . 0 0 1}\end{array}$ & $\begin{array}{l}\mathrm{F}=90.660 \\
\mathrm{df}=1,252 \\
\mathbf{P}<\mathbf{0 . 0 0 1}\end{array}$ \\
\hline Test* Species & $\begin{array}{l}F=2.403 \\
d f=6,347 \\
P=\mathbf{0 . 0 2 7}\end{array}$ & $\begin{array}{l}F=5.451 \\
d f=6,336 \\
P<\mathbf{0 . 0 0 1}\end{array}$ & $\begin{array}{l}F=5.914 \\
d f=4,256 \\
P<\mathbf{0 . 0 0 1}\end{array}$ & $\begin{array}{l}\mathrm{F}=3.803 \\
\mathrm{df}=4,252 \\
\mathbf{P}=\mathbf{0 . 0 0 5}\end{array}$ \\
\hline Test* Concentration & N/A & $\begin{array}{l}\mathrm{F}=2.793 \\
\mathrm{df}=3,336 \\
\mathbf{P}=\mathbf{0 . 0 4 0}\end{array}$ & $\begin{array}{l}F=3.137 \\
d f=2,256 \\
P=\mathbf{0 . 0 4 5}\end{array}$ & N/A \\
\hline $\begin{array}{l}\text { Species* } \\
\text { Concentration }\end{array}$ & N/A & $\begin{array}{l}\mathrm{F}=7.164 \\
\mathrm{df}=2,336 \\
\mathbf{P}=\mathbf{0 . 0 0 1}\end{array}$ & $\begin{array}{l}\mathrm{F}=4.656 \\
\mathrm{df}=2,256 \\
\mathbf{P}=\mathbf{0 . 0 1 0}\end{array}$ & $\begin{array}{l}F=15.666 \\
d f=2,252 \\
P<\mathbf{0 . 0 0 1}\end{array}$ \\
\hline $\begin{array}{l}\text { Test* Species * } \\
\text { Concentration }\end{array}$ & N/A & $\begin{array}{l}F=5.905 \\
d f=6,336 \\
P<\mathbf{0 . 0 0 1}\end{array}$ & N/A & $\begin{array}{l}F=3.588 \\
d f=6,252 \\
P=\mathbf{0 . 0 0 2}\end{array}$ \\
\hline R-Squared & 0.431 & 0.358 & 0.463 & 0.445 \\
\hline
\end{tabular}


Table 4.4. Summary of the main effects of test condition and species on percent control conductance seven days after spray for terrestrial and wetland plants sprayed with glyphosate and atrazine. The estimated marginal geometric means are shown with $95 \%$ confidence intervals indicated in brackets. The means were evaluated at the overall average concentration value for each model for comparability between tests. The lowest mean for each level is indicated in bold. Means followed by the same letter are not statistically different while means followed by different letters are statistically different at the estimated marginal geometric mean.

\begin{tabular}{|c|c|c|c|c|c|}
\hline Test & $\begin{array}{l}\text { Glyphosate } \\
\text { Terrestrial Tests }\end{array}$ & $\begin{array}{l}\text { Atrazine Terrestrial } \\
\text { Tests }\end{array}$ & Test & $\begin{array}{l}\text { Glyphosate Wetland } \\
\text { Tests }\end{array}$ & $\begin{array}{l}\text { Atrazine Wetland } \\
\text { Tests }\end{array}$ \\
\hline Single Species & $\begin{array}{c}0.3419^{\mathrm{a}} \\
(0.2895-0.3988)\end{array}$ & $\begin{array}{c}0.9127^{\mathrm{ab}} \\
(0.7830-1.0523)\end{array}$ & Single Species & $\begin{array}{c}0.1944^{\mathrm{ab}} \\
(0.1642-0.2263)\end{array}$ & $\begin{array}{c}\mathbf{0 . 6 5 7 4}^{\mathbf{b}} \\
(0.5797-0.7389)\end{array}$ \\
\hline $\begin{array}{l}\text { Greenhouse } \\
\text { Microcosm }\end{array}$ & $\begin{array}{c}\mathbf{0 . 2 9 1 9}^{\mathbf{a}} \\
(0.2434-0.3443)\end{array}$ & $\begin{array}{c}\mathbf{0 . 5 7 4 1}^{\mathbf{c}} \\
(0.5033-0.6495)\end{array}$ & $\begin{array}{l}\text { Greenhouse } \\
\text { Microcosm }\end{array}$ & $\begin{array}{c}\mathbf{0 . 1 5 2 9}^{\mathrm{b}} \\
(0.1248-0.1824)\end{array}$ & $\begin{array}{c}0.7452^{\mathrm{b}} \\
(0.6645-0.8299)\end{array}$ \\
\hline $\begin{array}{l}\text { Long-term } \\
\text { Microcosm }\end{array}$ & $\begin{array}{c}0.3613^{\mathrm{a}} \\
(0.3077-0.4195)\end{array}$ & $\begin{array}{c}0.7100^{\mathrm{bc}} \\
(0.6302-0.7945)\end{array}$ & $\begin{array}{l}\text { Long-term } \\
\text { Microcosm }\end{array}$ & $\begin{array}{c}0.2093^{\mathrm{a}} \\
(0.1784-0.2418) \\
\end{array}$ & $\begin{array}{c}0.9152^{\bar{a}} \\
(0.8269-1.0077) \\
\end{array}$ \\
\hline Outdoor Microcosm & $\begin{array}{c}0.3446^{\mathrm{a}} \\
(0.2922-0.4013)\end{array}$ & $\begin{array}{c}0.8935^{\mathrm{a}} \\
(0.8037-0.9880)\end{array}$ & & & \\
\hline Species & & & Species & & \\
\hline S. lateriflorum & $\begin{array}{c}0.3684^{\mathrm{a}} \\
(0.3212-0.4190)\end{array}$ & $\begin{array}{c}0.8449^{\mathrm{ab}} \\
(0.7528-0.9424)\end{array}$ & E. maculatum & $\begin{array}{c}\mathbf{0 . 1 5 7 0}^{\mathbf{b}} \\
(0.1287-0.1868)\end{array}$ & $\begin{array}{c}0.7392^{b} \\
(0.6588-0.8235)\end{array}$ \\
\hline A. petiolata & $\begin{array}{c}\mathbf{0 . 2 9 7 7}^{\mathbf{a}} \\
(0.2551-0.3433) \\
\end{array}$ & $\begin{array}{c}0.7908^{\mathrm{a}} \\
(0.7167-0.8686)\end{array}$ & L. americanus & $\begin{array}{c}0.2377^{\mathrm{a}} \\
(0.2054-0.2717)\end{array}$ & $\begin{array}{c}\mathbf{0 . 6 6 3 9}^{\mathbf{a}} \\
(0.5870-0.7446)\end{array}$ \\
\hline G. canadense & $\begin{array}{c}0.3390^{\mathrm{a}} \\
(0.2937-0.3876) \\
\end{array}$ & $\begin{array}{c}\mathbf{0 . 6 6 7 8}^{\mathbf{b}} \\
(0.5918-0.7483)\end{array}$ & P. arundinacea & $\begin{array}{c}0.1637^{b} \\
(0.1350-0.1939)\end{array}$ & $\begin{array}{c}0.9142^{6} \\
(0.8247-1.0081)\end{array}$ \\
\hline $\begin{array}{l}\text { Concentration (g } \\
\text { ai/ ha) }\end{array}$ & 266 & 228 & & 152 & 220 \\
\hline
\end{tabular}


Table 4.5. Summary of nonparametric correlations between percent control biomass and day 7 percent control stomatal conductance for terrestrial and wetland single species tests, greenhouse, outdoor (terrestrial only) and long-term microcosm tests treated with glyphosate and atrazine. Long-term microcosms were analyzed separately because biomass was harvested on day 60 or 70 rather then on day 28 . Correlations are significant at $\mathrm{P}<\mathbf{0 . 0 5}$.

\begin{tabular}{|c|c|c|c|c|c|}
\hline & & $\begin{array}{l}\text { Glyphosate } \\
\text { Terrestrial } \\
\text { Tests }\end{array}$ & $\begin{array}{l}\text { Atrazine } \\
\text { Terrestrial } \\
\text { Tests }\end{array}$ & $\begin{array}{l}\text { Glyphosate } \\
\text { Wetland } \\
\text { Tests }\end{array}$ & $\begin{array}{l}\text { Atrazine } \\
\text { Wetland } \\
\text { Tests }\end{array}$ \\
\hline $\begin{array}{l}\text { Day } 7 \\
\text { Conductance } \\
\text { Day } 28 \text { Biomass }\end{array}$ & $\begin{array}{l}\text { Spearman's rho } \\
\text { correlation } \\
\text { coefficient } \\
\text { 2-tailed } \\
\text { significance } \\
\text { Sample Size }\end{array}$ & $\begin{array}{l}0.659 \\
<0.001 \\
270\end{array}$ & $\begin{array}{l}0.359 \\
<0.001 \\
270\end{array}$ & $\begin{array}{l}0.706 \\
<0.001 \\
180\end{array}$ & $\begin{array}{l}0.509 \\
<0.001 \\
180\end{array}$ \\
\hline $\begin{array}{l}\text { Day } 7 \\
\text { Conductance } \\
\text { Day } 60 \text { or } 70 \\
\text { Biomass }\end{array}$ & $\begin{array}{l}\text { Spearman's rho } \\
\text { correlation } \\
\text { coefficient } \\
\text { 2-tailed } \\
\text { significance } \\
\text { Sample Size }\end{array}$ & $\begin{array}{l}0.506 \\
<0.001 \\
90\end{array}$ & $\begin{array}{l}0.278 \\
<0.001 \\
90\end{array}$ & $\begin{array}{l}<0.001 \\
90\end{array}$ & $\begin{array}{l}<0.001 \\
90\end{array}$ \\
\hline
\end{tabular}




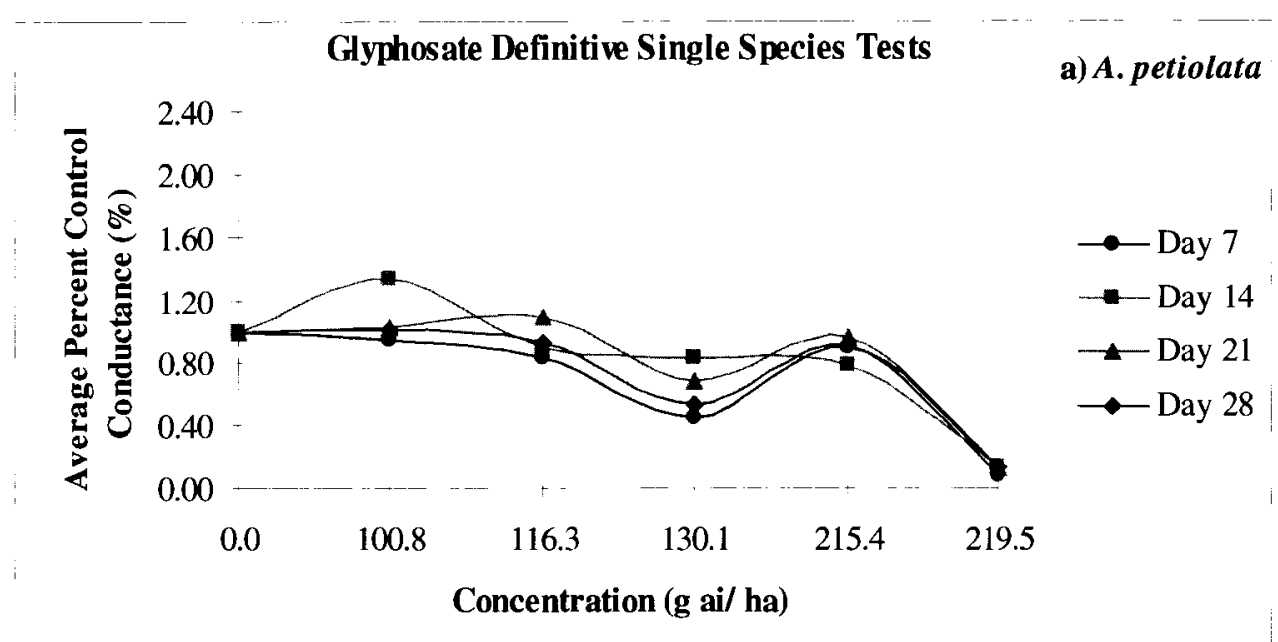

b) G. canadense

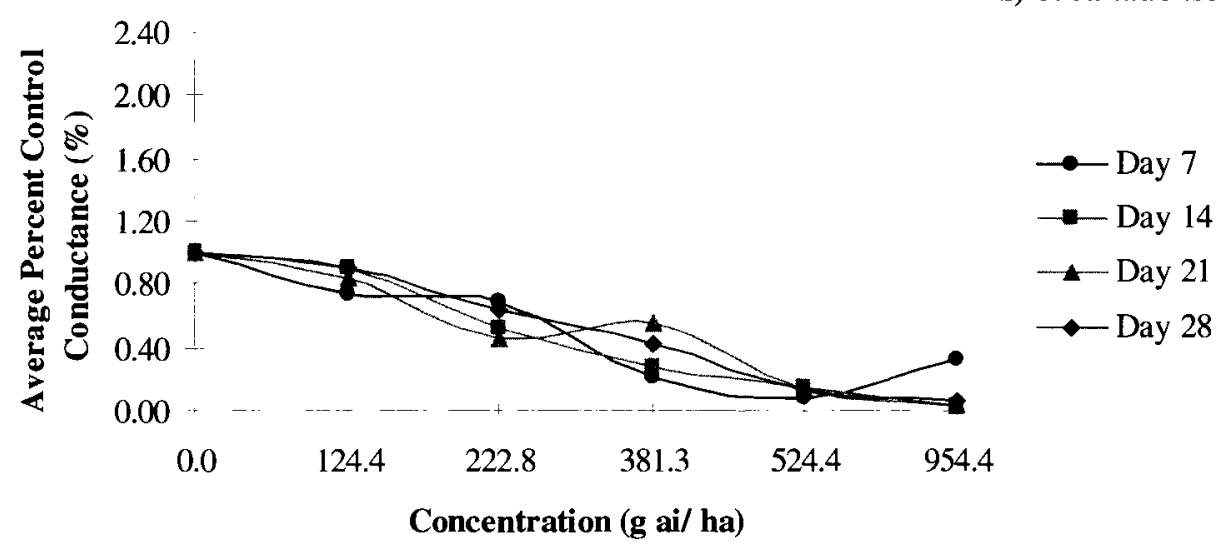

c) S. lateriflorum

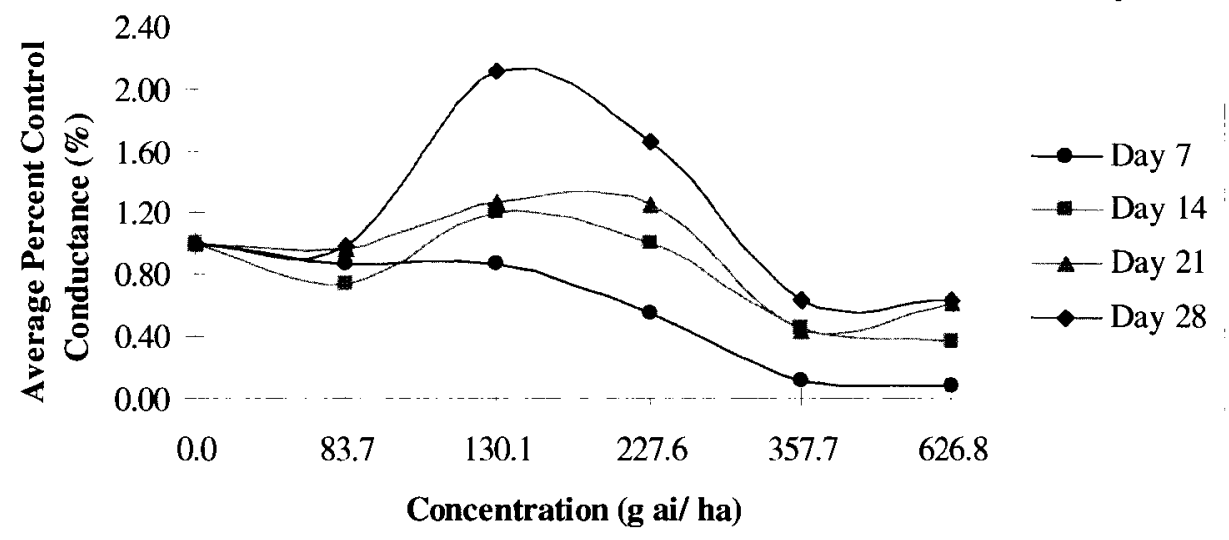

Figure 4.1. The effects of glyphosate on percent control conductance 7, 14, 21 and 28 days after spray for the terrestrial plants a) $A$. petiolata, b) $G$. canadense and c) $S$. lateriflorum grown singly in pots. 


\section{Glyphosate Greenhouse Microcosm Tests}
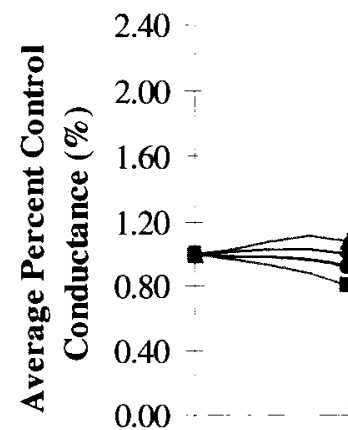

0.80

0.40 0.00

0.0

96.7

$\longrightarrow$ - Day 7

$\rightarrow$ Day 14

$\rightarrow$ Day 21

$\rightarrow$ Day 28

Concentration (g ai/ ha)

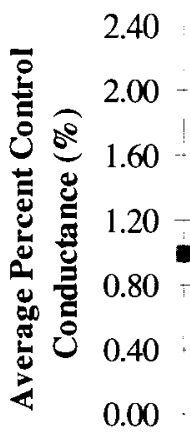

40

b) G. canadense $-$ 


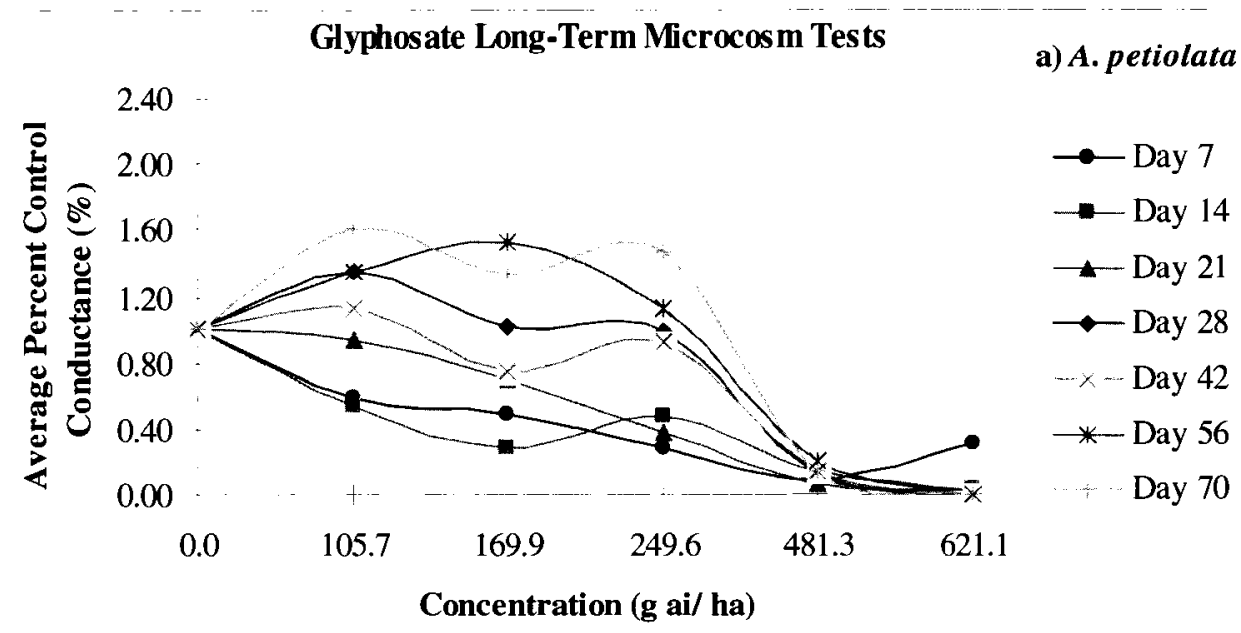

b) G. canadense
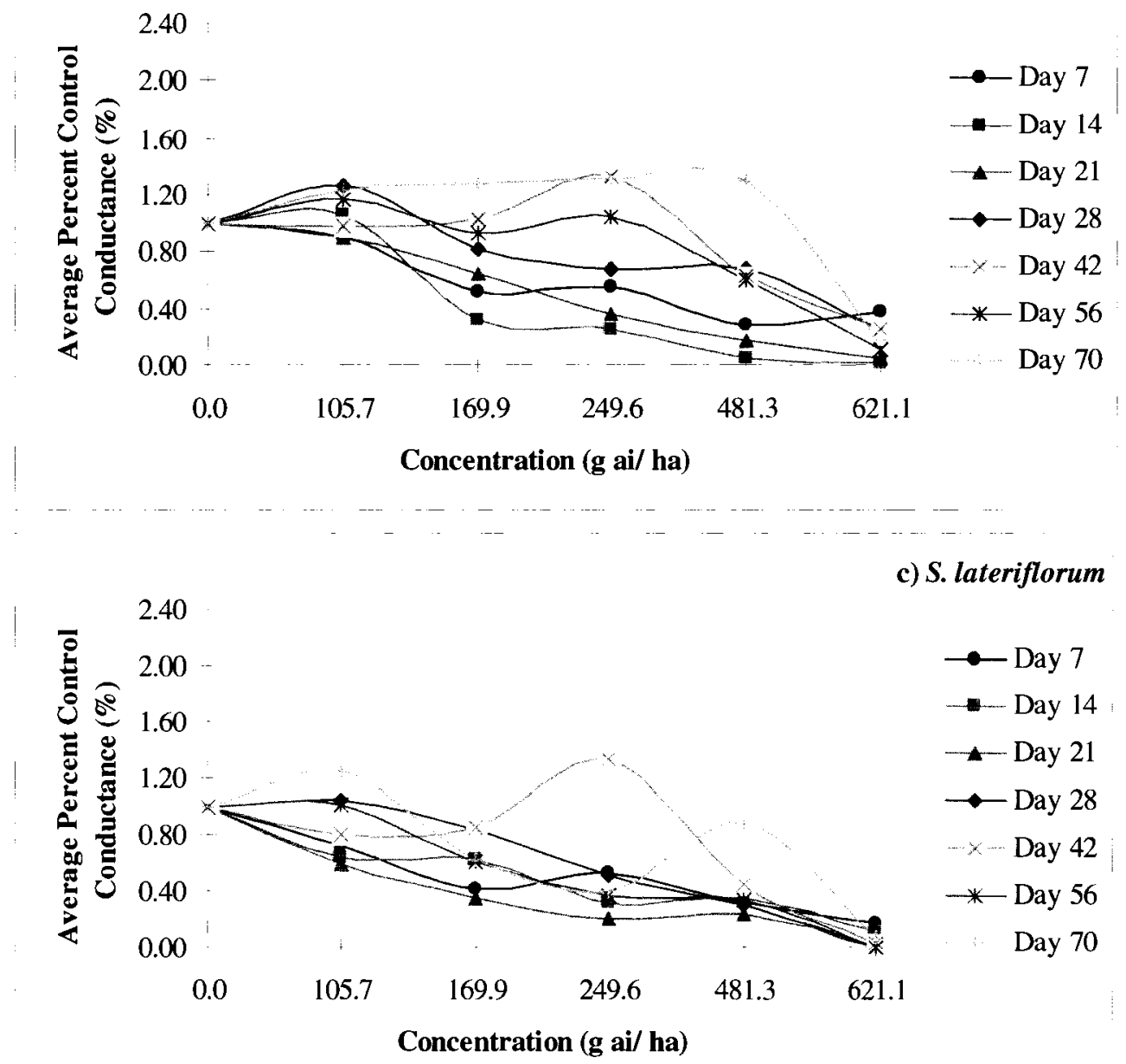

Figure 4.3. The effects of glyphosate on percent control conductance 7, 14, 21, 28, 42, 56 and 70 days after spray for the terrestrial plants a) $A$. petiolata, b) $G$. canadense and c) $S$. lateriflorum grown in long-term microcosms. 


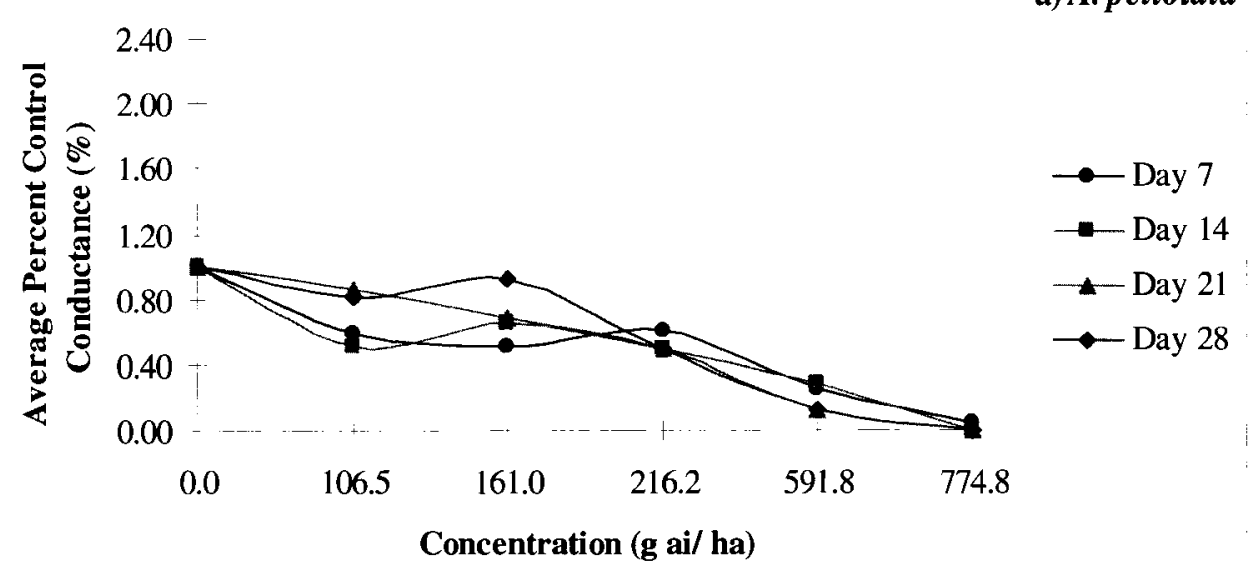

b) G. canadense

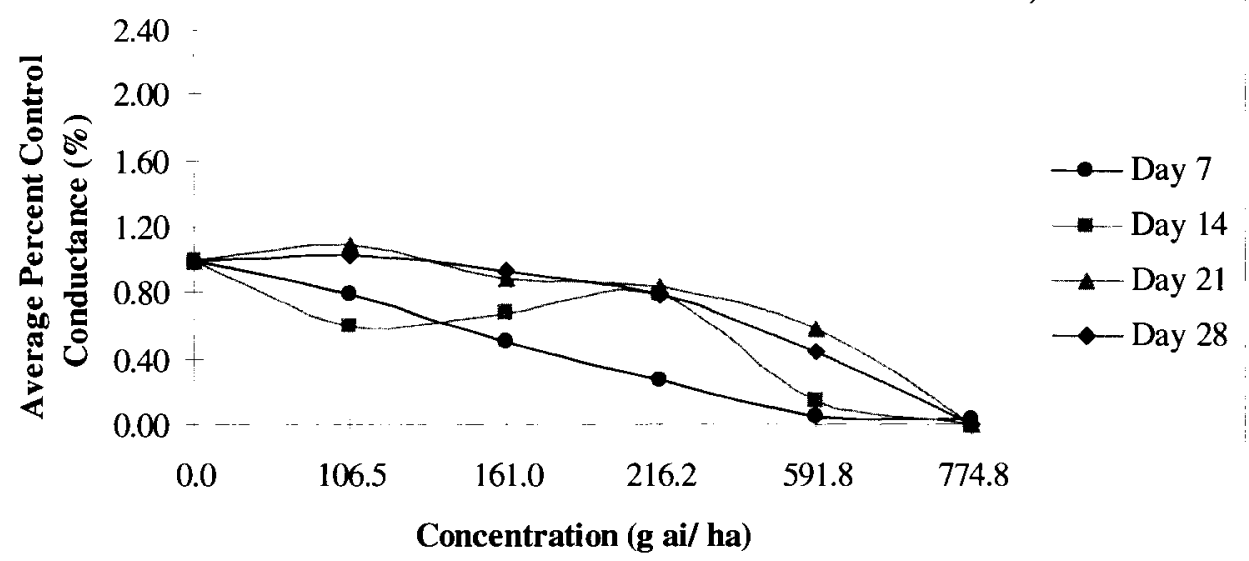

c) S. lateriflorum

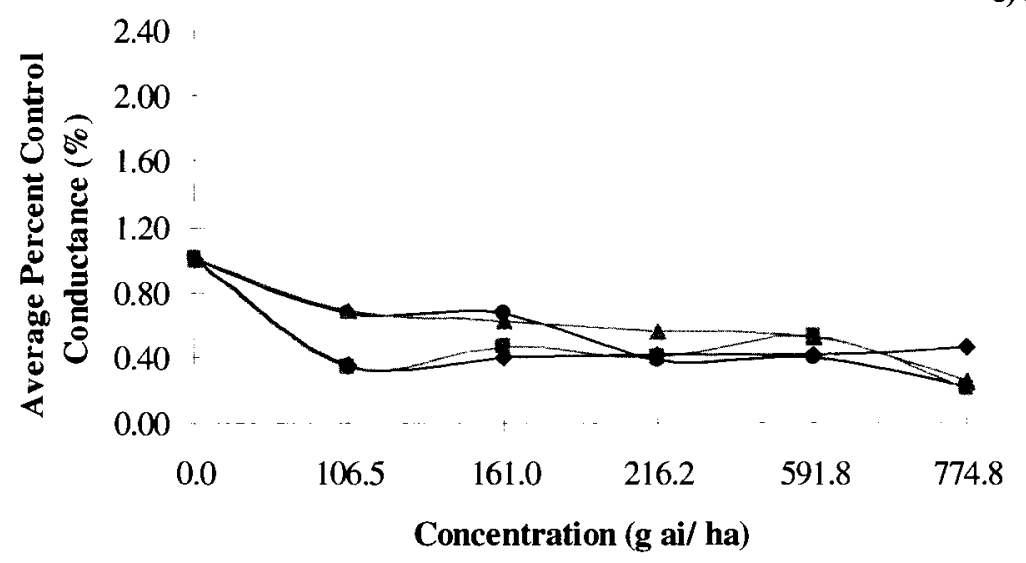

Figure 4.4. The effects of glyphosate on percent control conductance 7, 14, 21 and 28 days after spray for the terrestrial plants a) $A$. petiolata, b) $G$. canadense and c) $S$. lateriflorum grown in outdoor microcosms. 

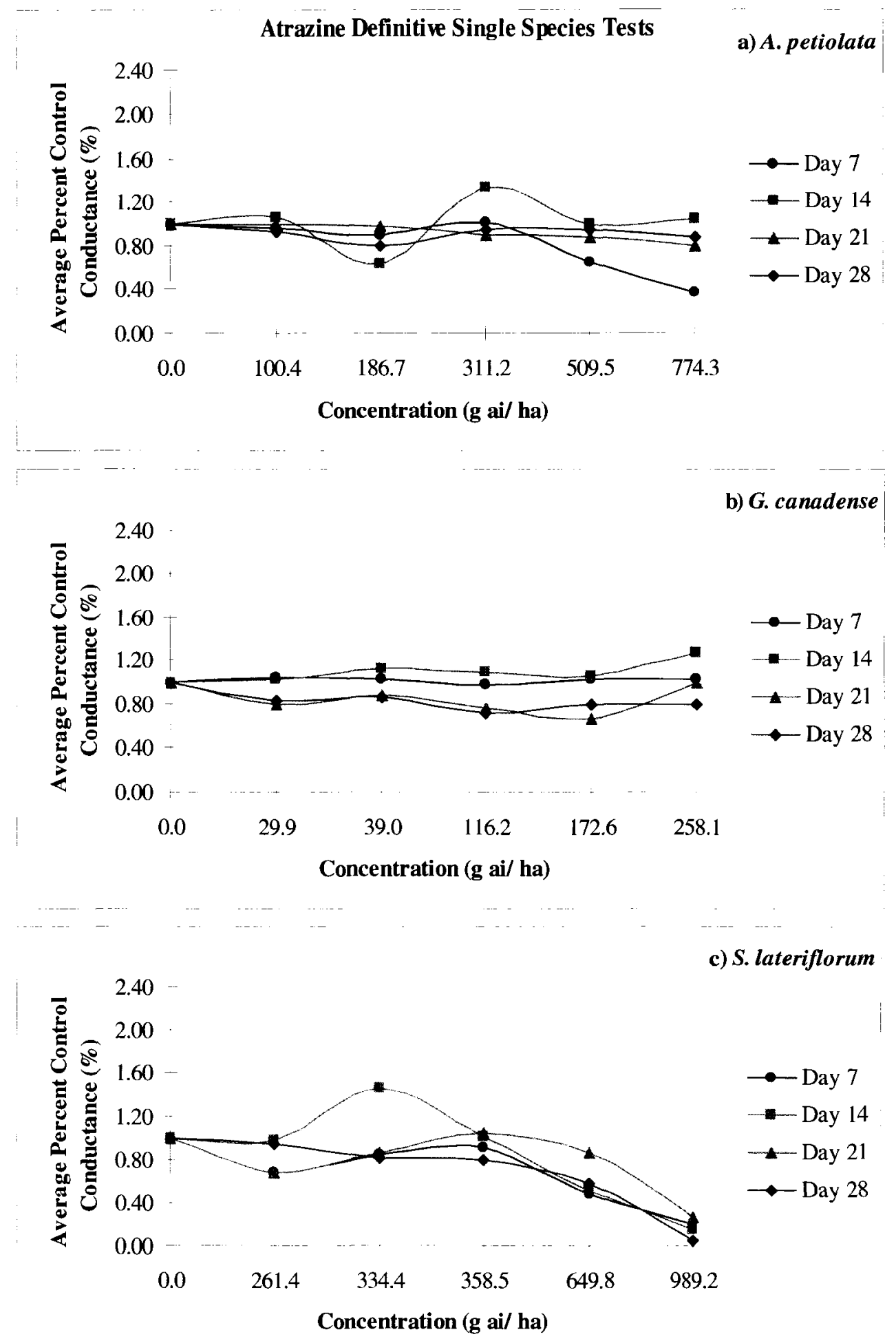

Figure 4.5. The effects of atrazine on percent control conductance $7,14,21$ and 28 days after spray for the terrestrial plants a) $A$. petiolata, b) $G$. canadense and c) $S$. lateriflorum grown singly in pots. 


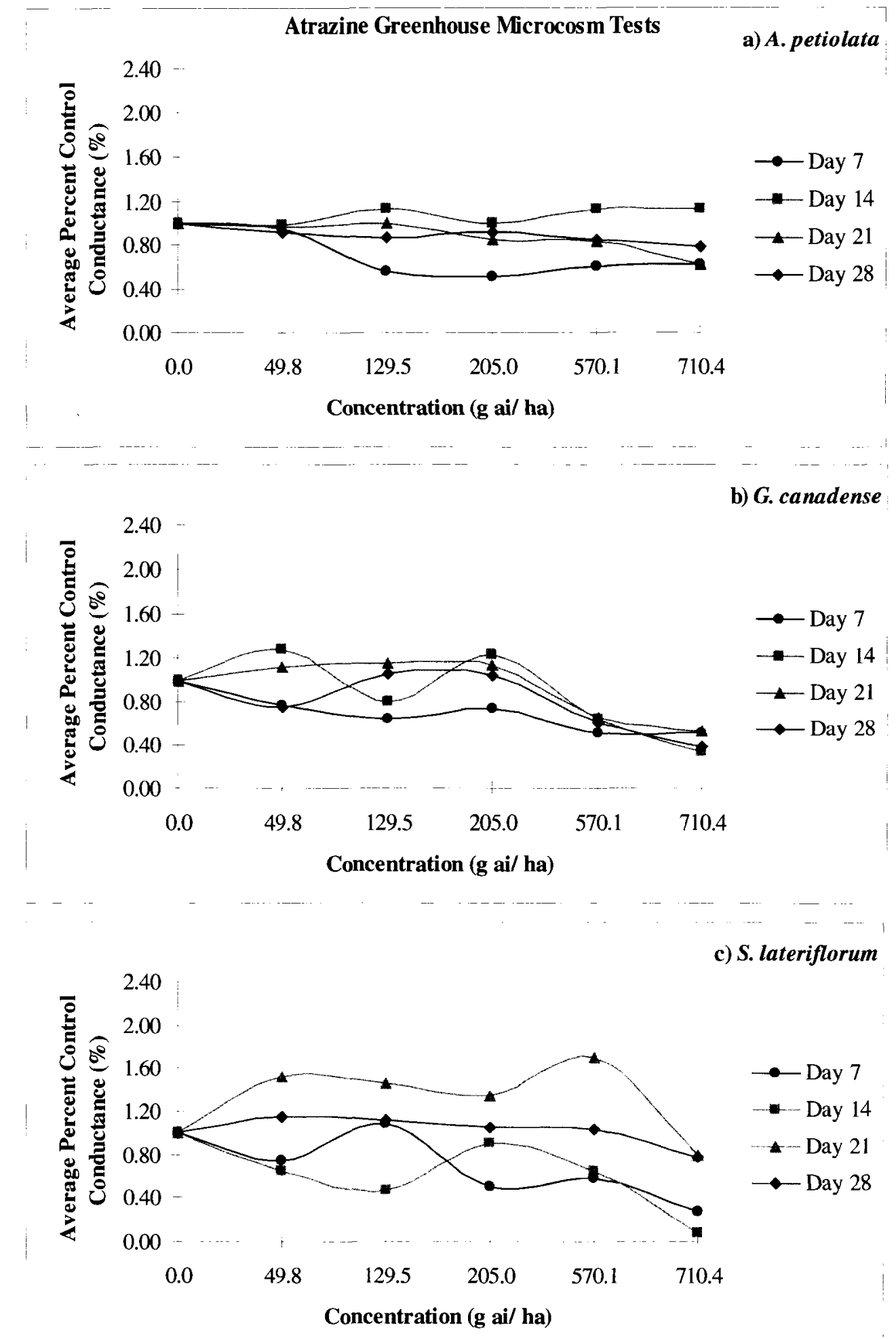

Figure 4.6. The effects of atrazine on percent control conductance 7, 14, 21 and 28 days after spray for the terrestrial plants a) A. petiolata, b) G. canadense and c) S. lateriflorum grown in greenhouse microcosms. 

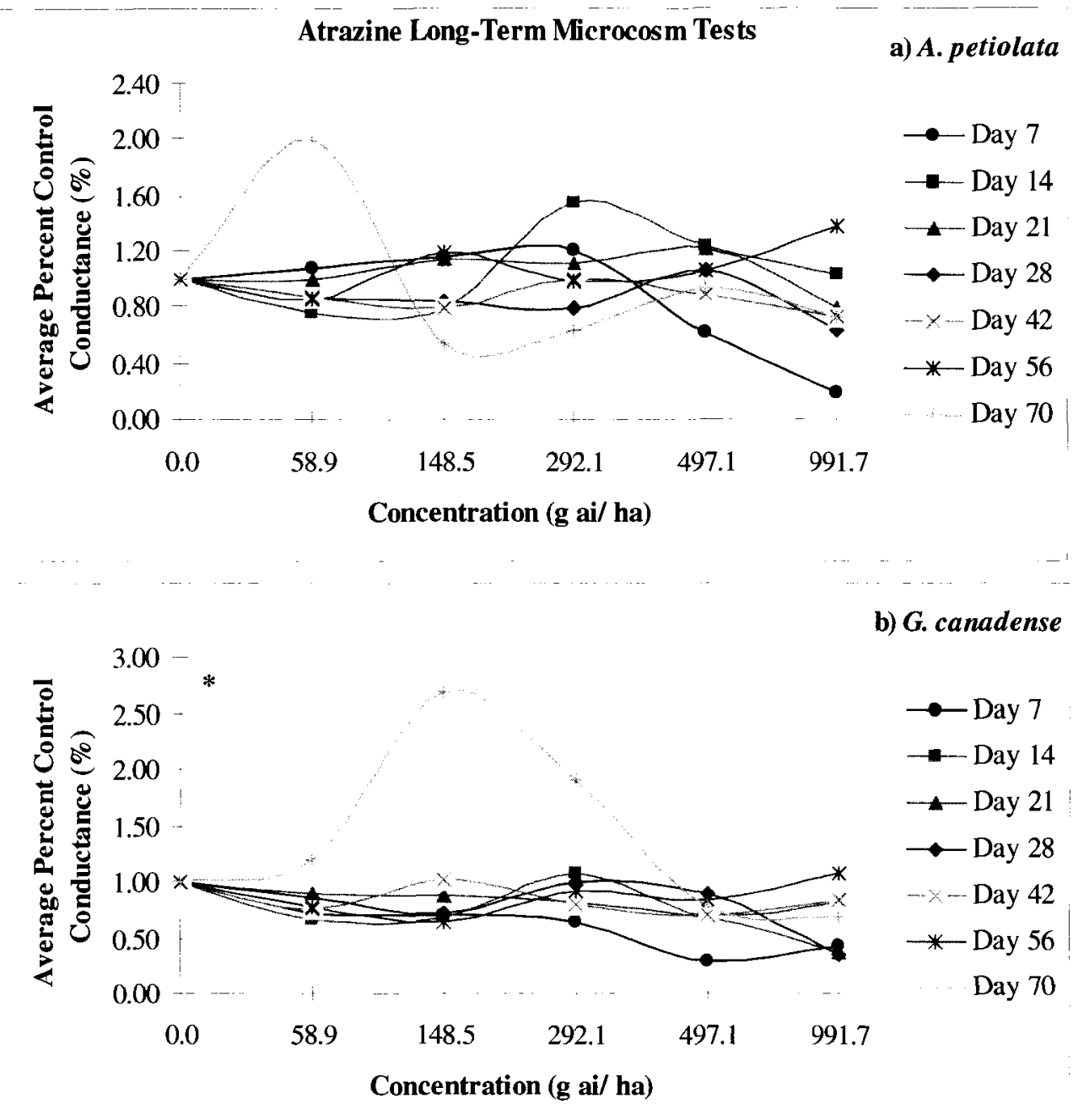

c) S. lateriflorum

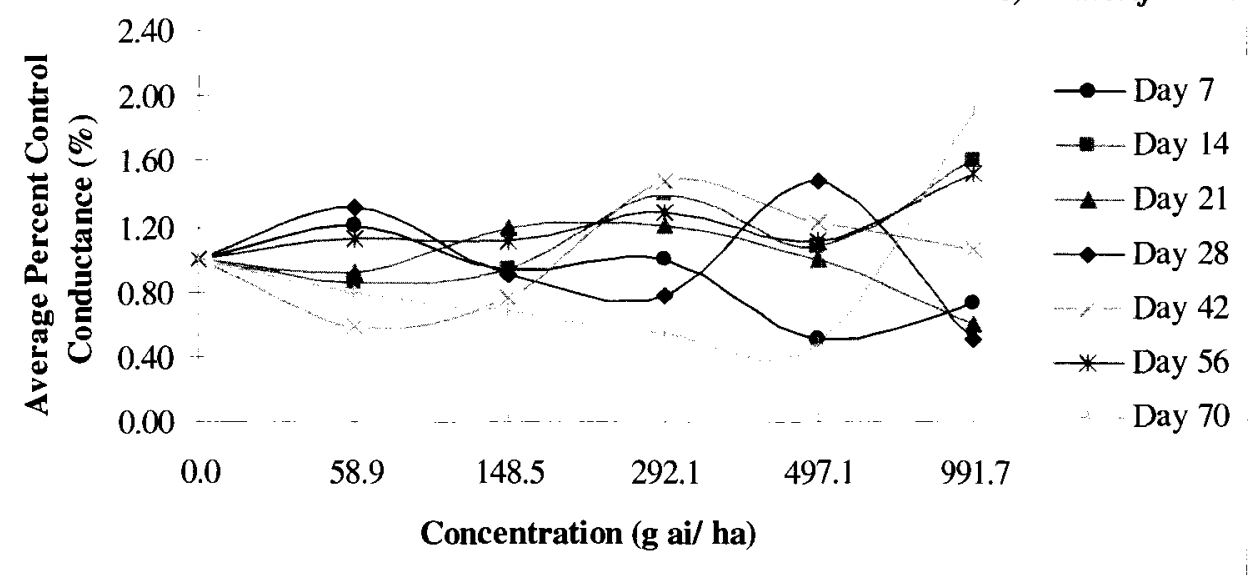

Figure 4.7. The effects of atrazine on percent control conductance 7, 14, 21, 28, 42, 56 and 70 days after spray for the terrestrial plants a) $A$. petiolata, b) $G$. canadense and c) $S$. lateriflorum grown in long-term microcosms. * $\mathrm{Y}$-axis is scaled differently from other graphs. 


\section{Atrazine Outdoor Microcosm Tests}

葛

2.40

a) A. petiolata

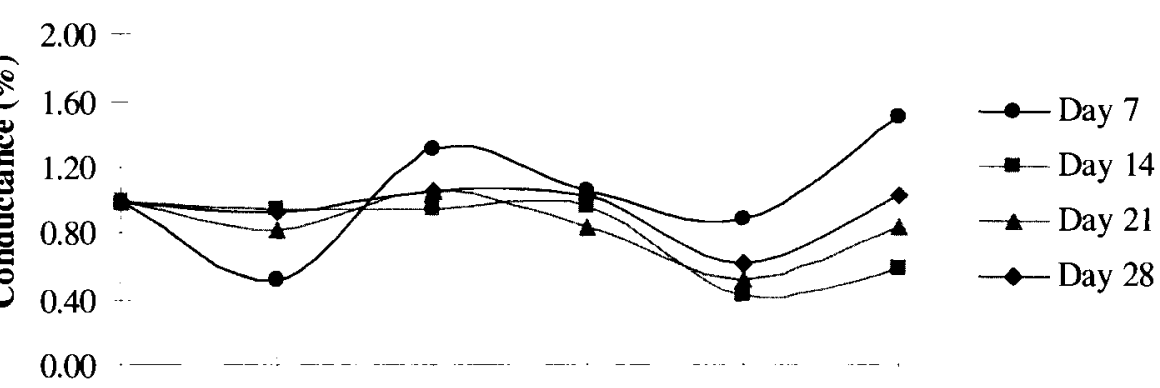

$0.0 \quad 49.8$

113.7

240.7

380.9

619.1

Concentration (g ai/ ha)

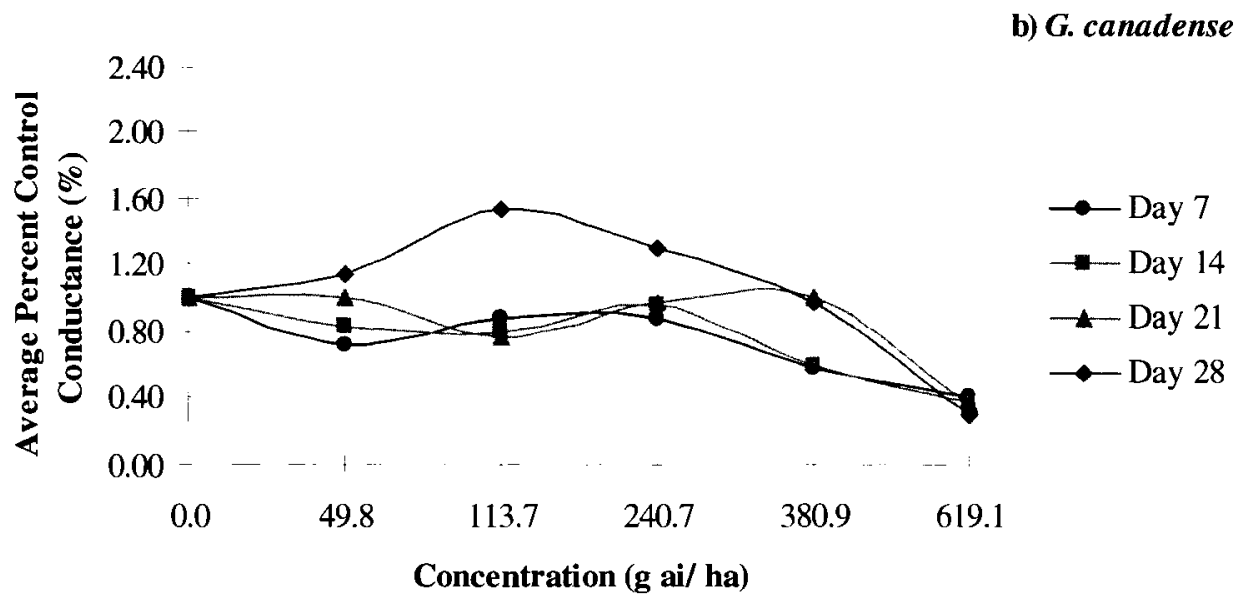

c) S. lateriflorum

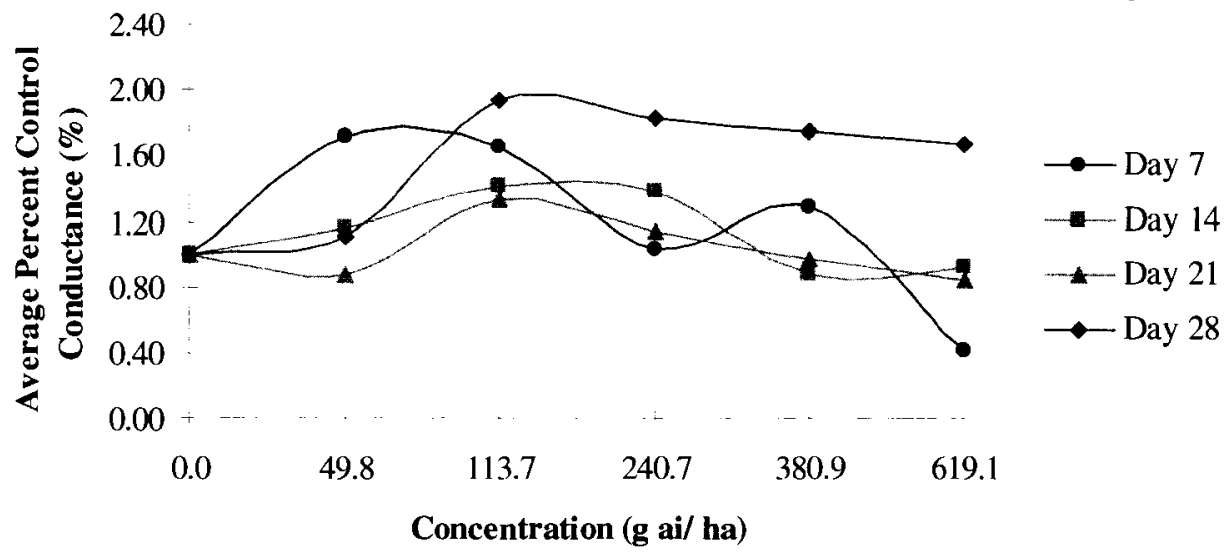

Figure 4.8. The effects of atrazine on percent control conductance 7, 14, 21 and 28 days after spray for the terrestrial plants a) $A$. petiolata, b) G. canadense and c) S. lateriflorum grown in outdoor microcosms. 

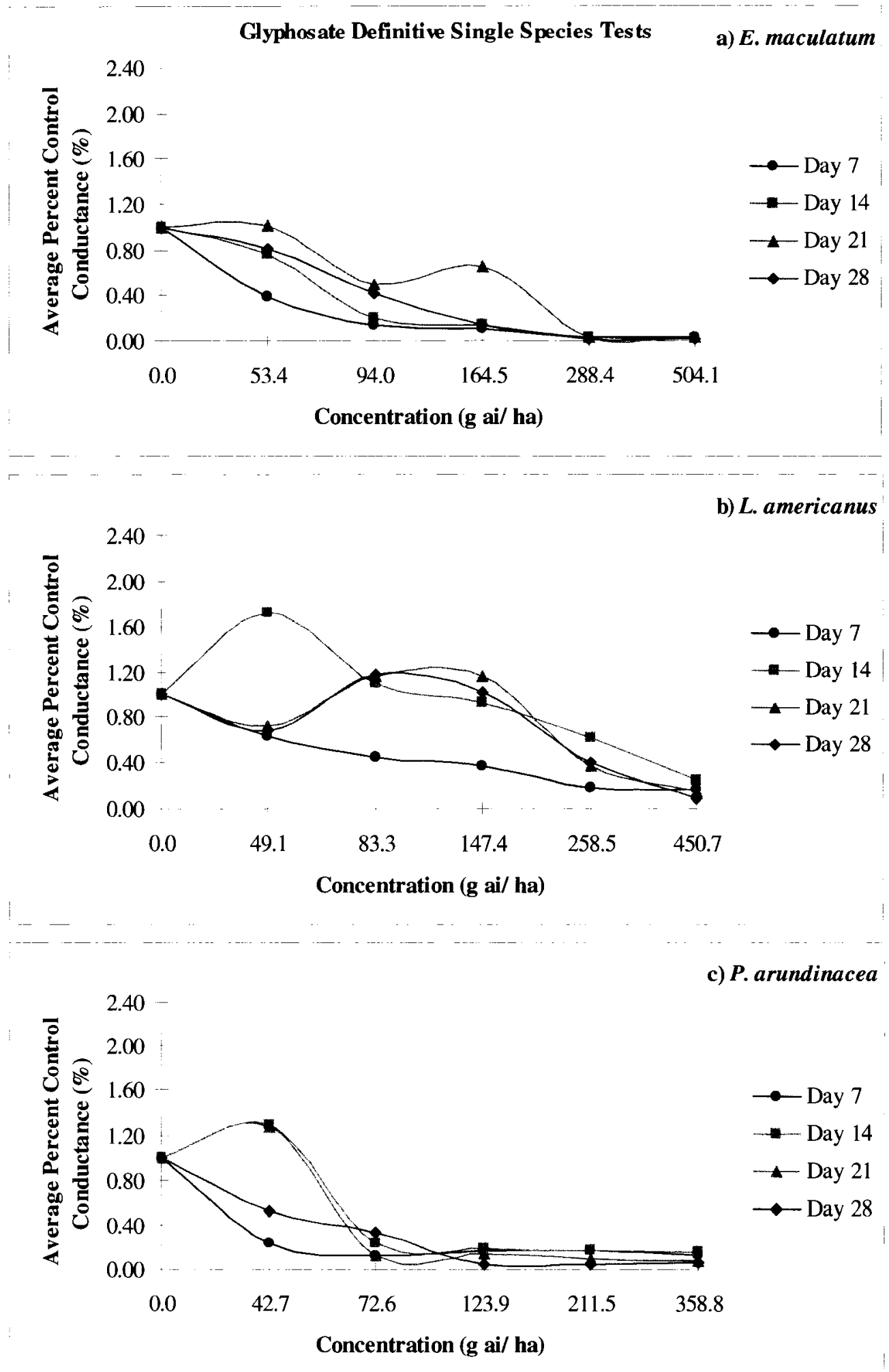

Figure 4.9. The effects of glyphosate on percent control conductance 7, 14, 21 and 28 days after spray for the wetland plants a) E. maculatum, b) L. americanus and c) $P$. arundinacea grown singly in pots. 


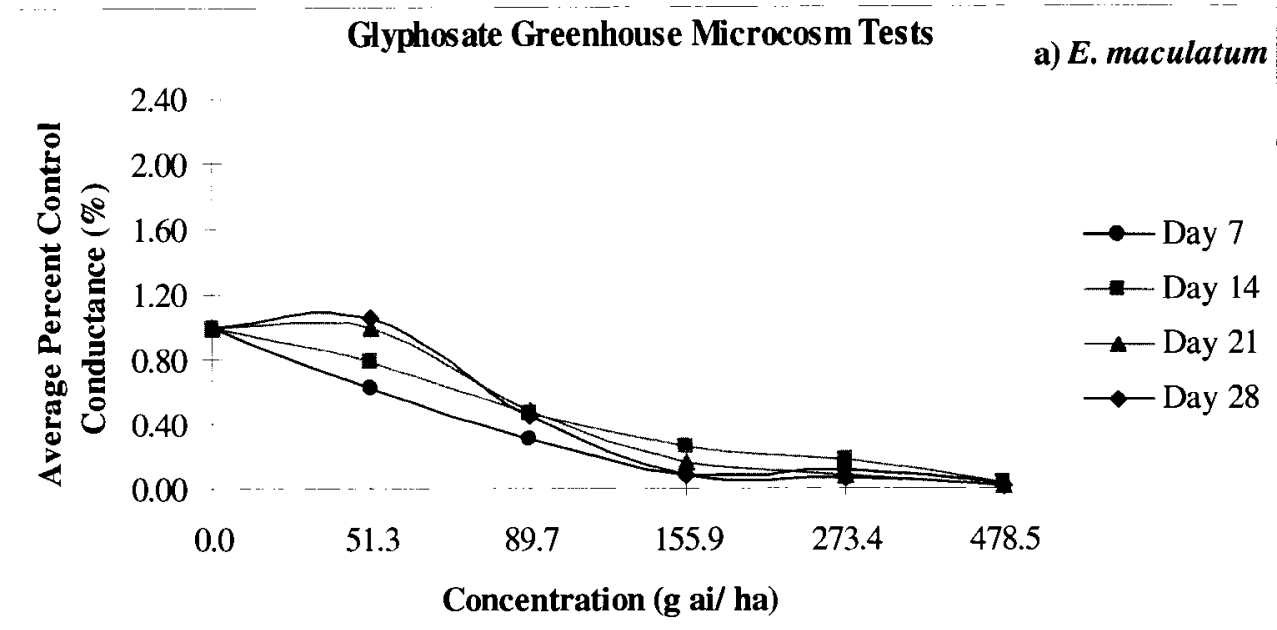

b) L. americanus

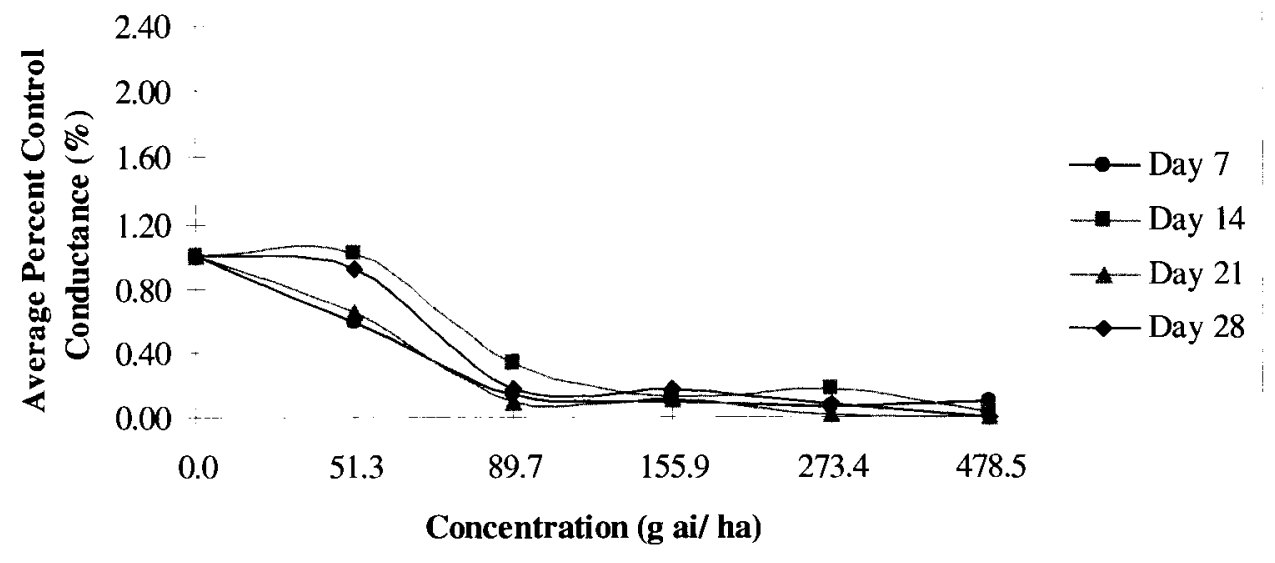

c) P. arundinacea

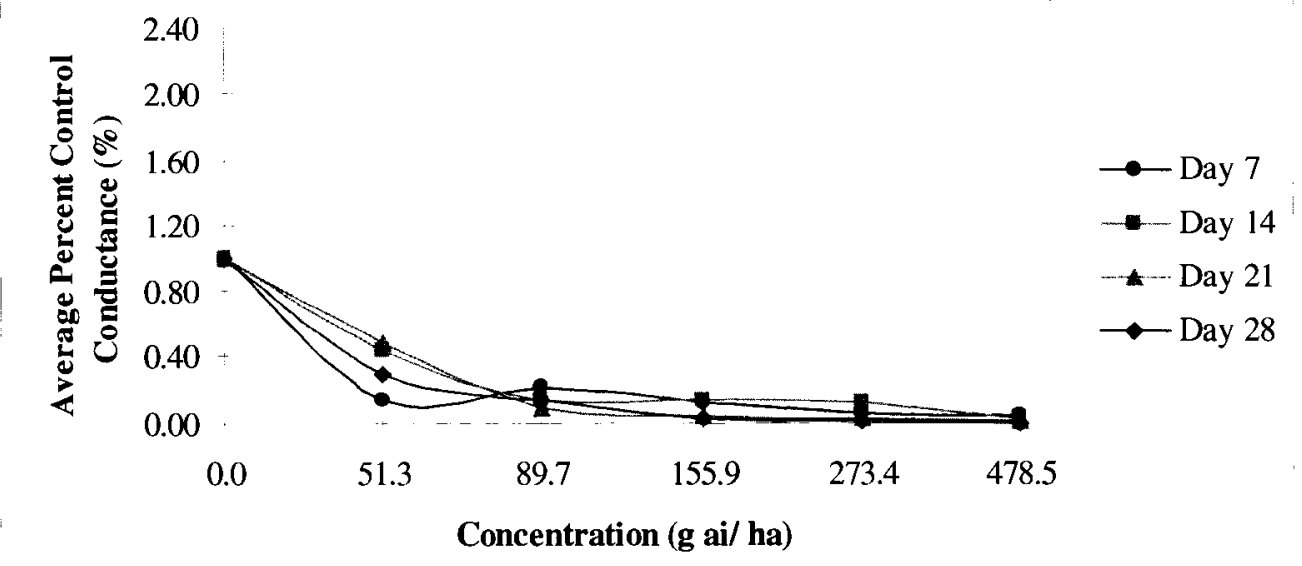

Figure 4.10. The effects of glyphosate on percent control conductance 7, 14, 21 and 28 days after spray for the wetland plants a) $E$. maculatum, b) $L$. americanus and c) $P$. arundinacea grown in greenhouse microcosms. 

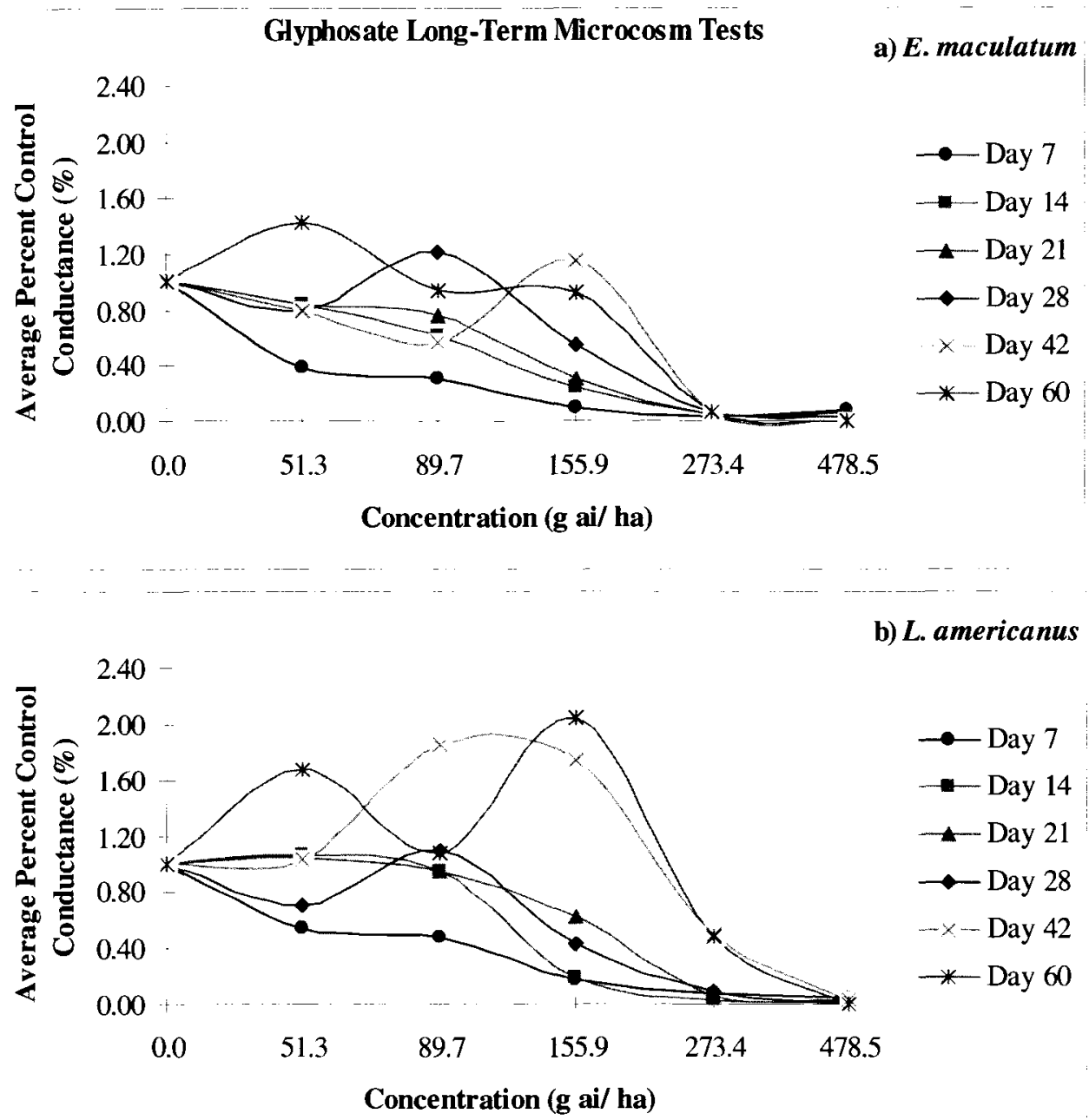

c) P. arundinacea

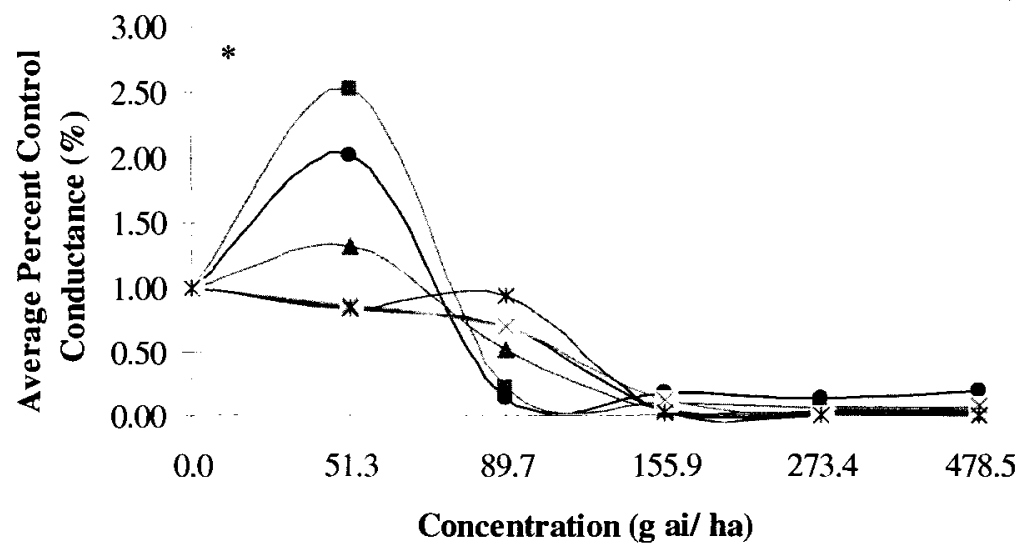

$\rightarrow$ Day 7

- Day 14

- Day 21

$\rightarrow$ Day 28

Day 42

* Day 60

Figure 4.11. The effects of glyphosate on percent control conductance $7,14,21,28,42$ and 60 days after spray for the wetland plants a) E. maculatum, b) L. americanus and c) $P$. arundinacea grown in long-term microcosms. * Y-axis is scaled differently from other graphs. 
Atrazine Definitive Single Species Tests

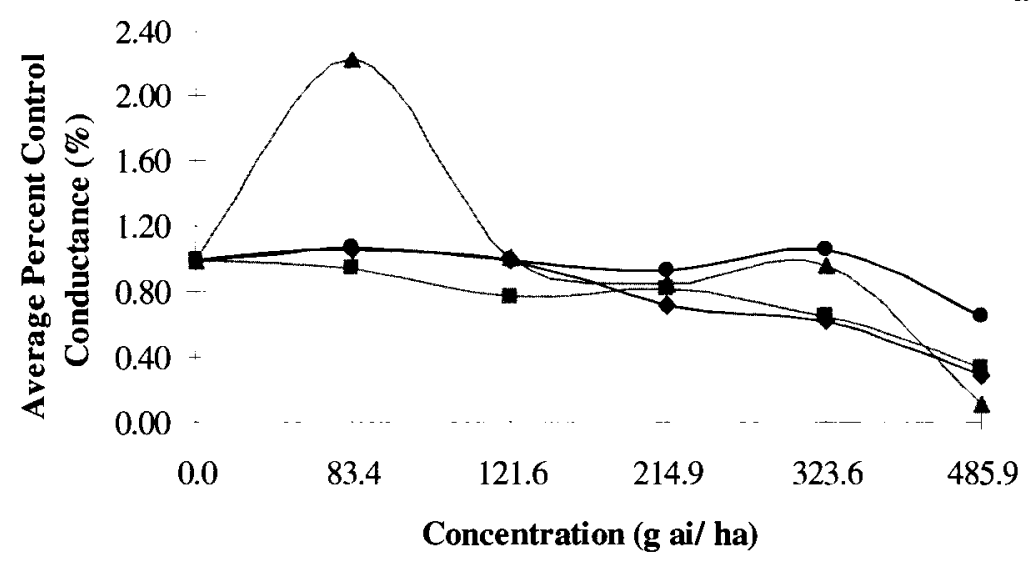

b) L. americanus

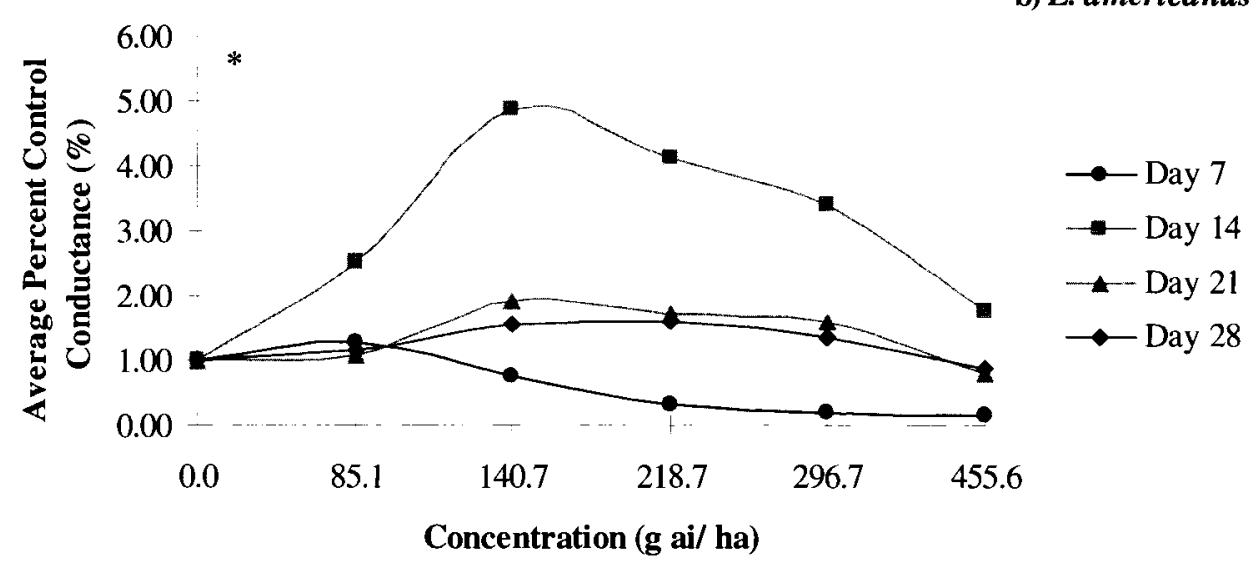

c) P. arundinacea

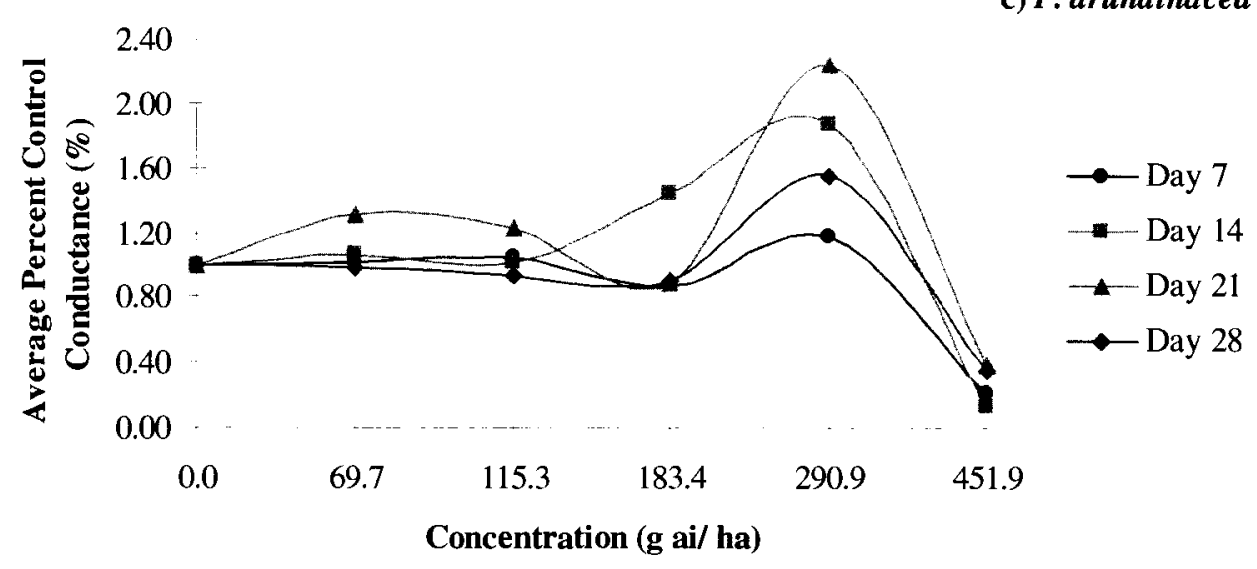

Figure 4.12. The effects of atrazine on percent control conductance 7, 14, 21 and 28 days after spray for the wetland plants a) E. maculatum, b) L. americanus and c) $P$. arundinacea grown singly in pots. * Y-axis is scaled differently from other graphs. 


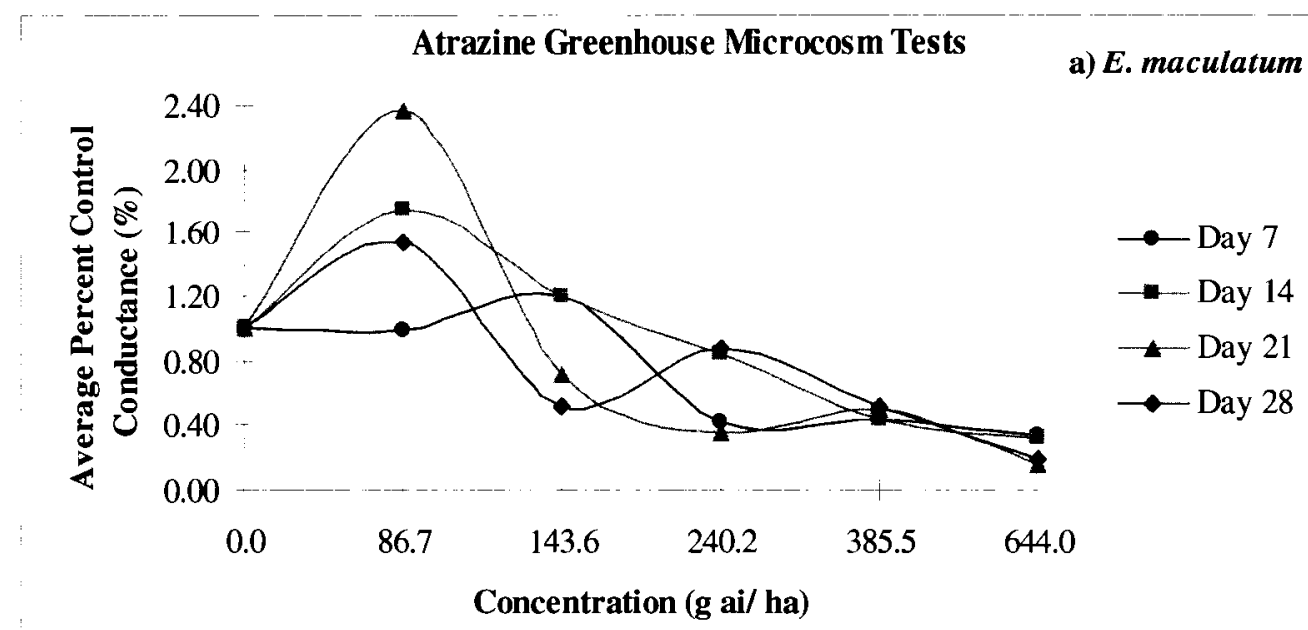

b) L. americanus

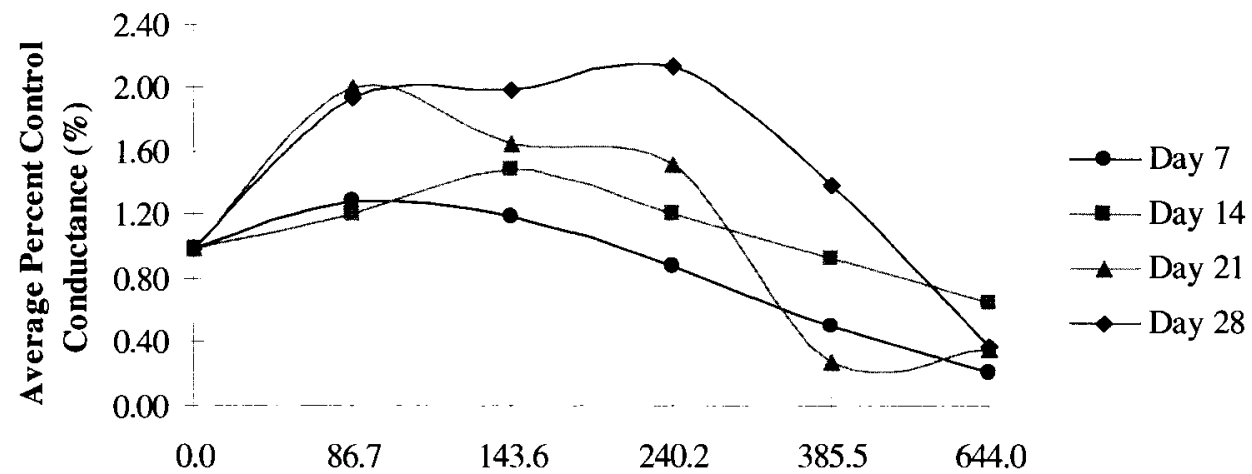

Concentration (g ai/ ha)

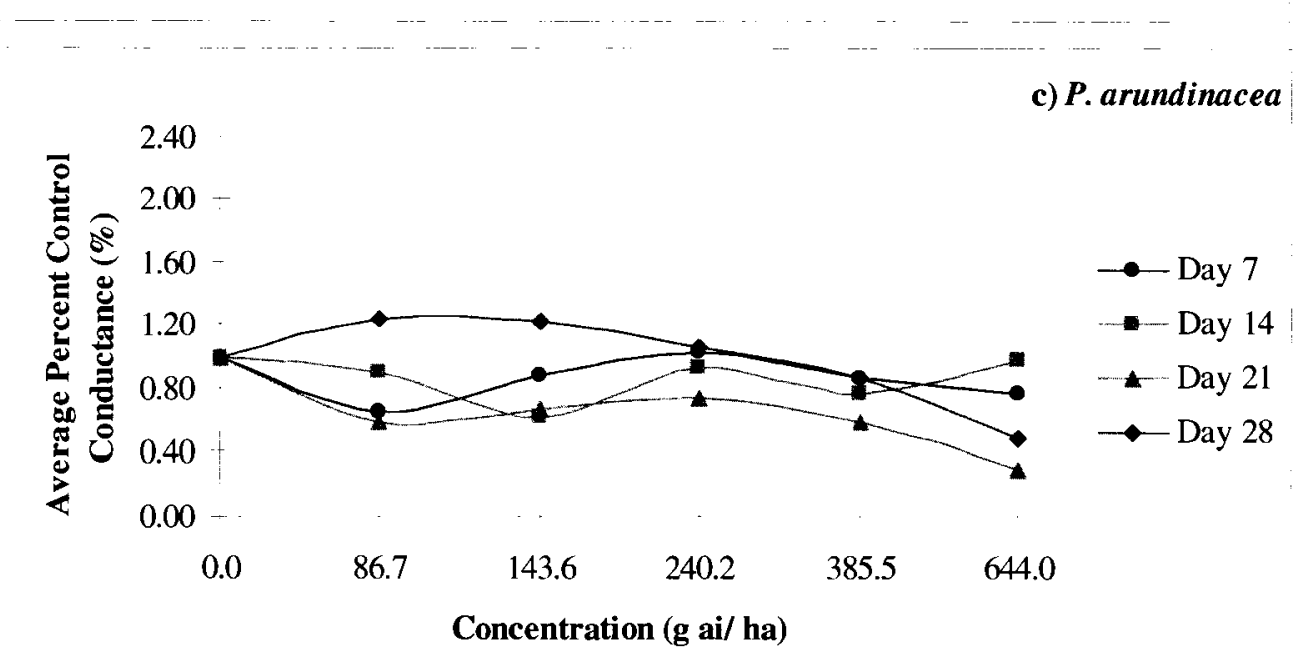

Figure 4.13. The effects of atrazine on percent control conductance 7, 14, 21 and 28 days after spray for the wetland plants a) E. maculatum, b) L. americanus and c) $P$. arundinacea grown in greenhouse microcosms. 

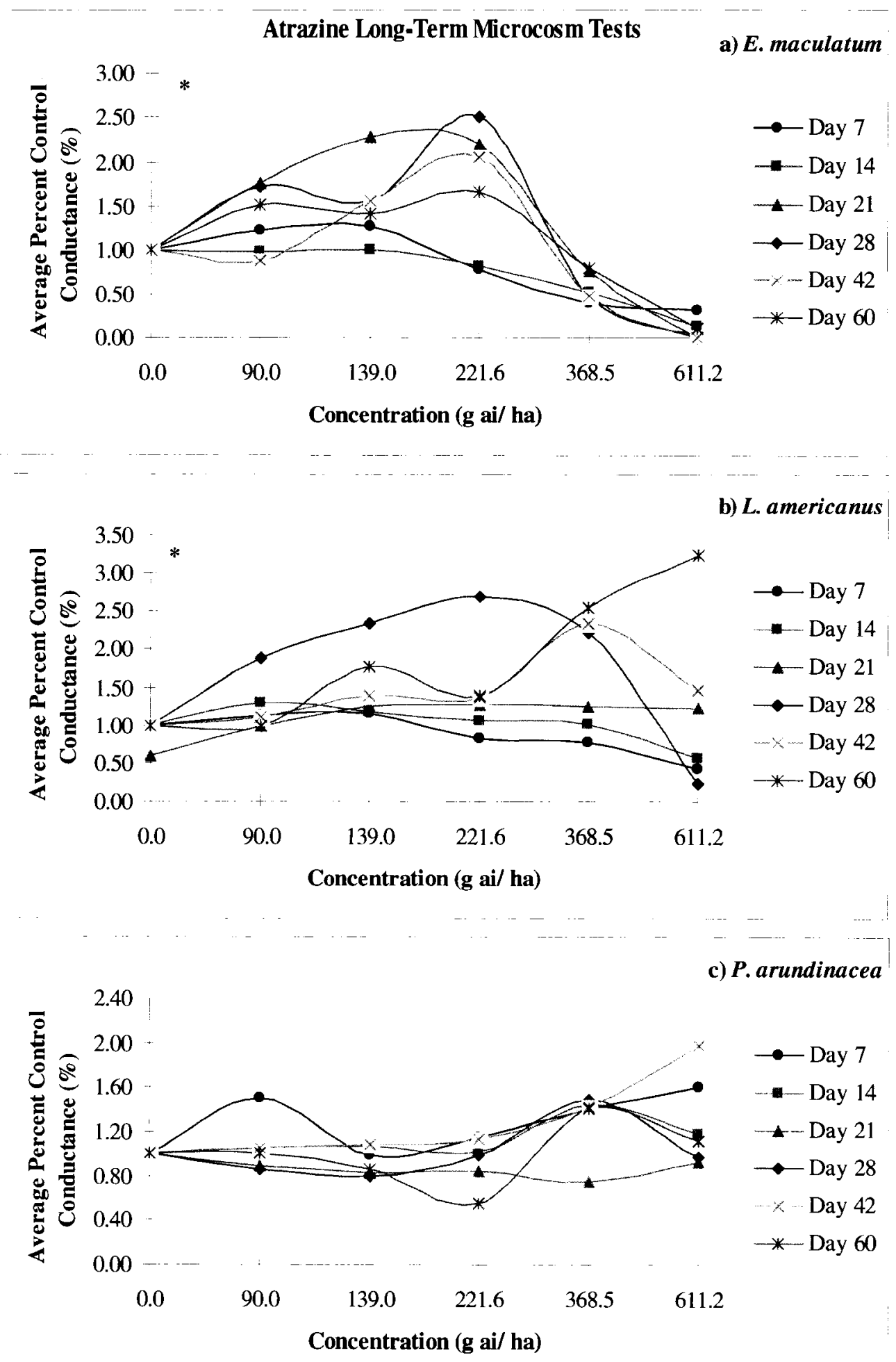

Figure 4.14. The effects of atrazine on percent control conductance 7, 14, 21, 28, 42 and 60 days after spray for the wetland plants a) E. maculatum, b) $L$. americanus and c) $P$. arundinacea grown in long-term microcosms. * Y-axis is scaled differently from other graphs. 


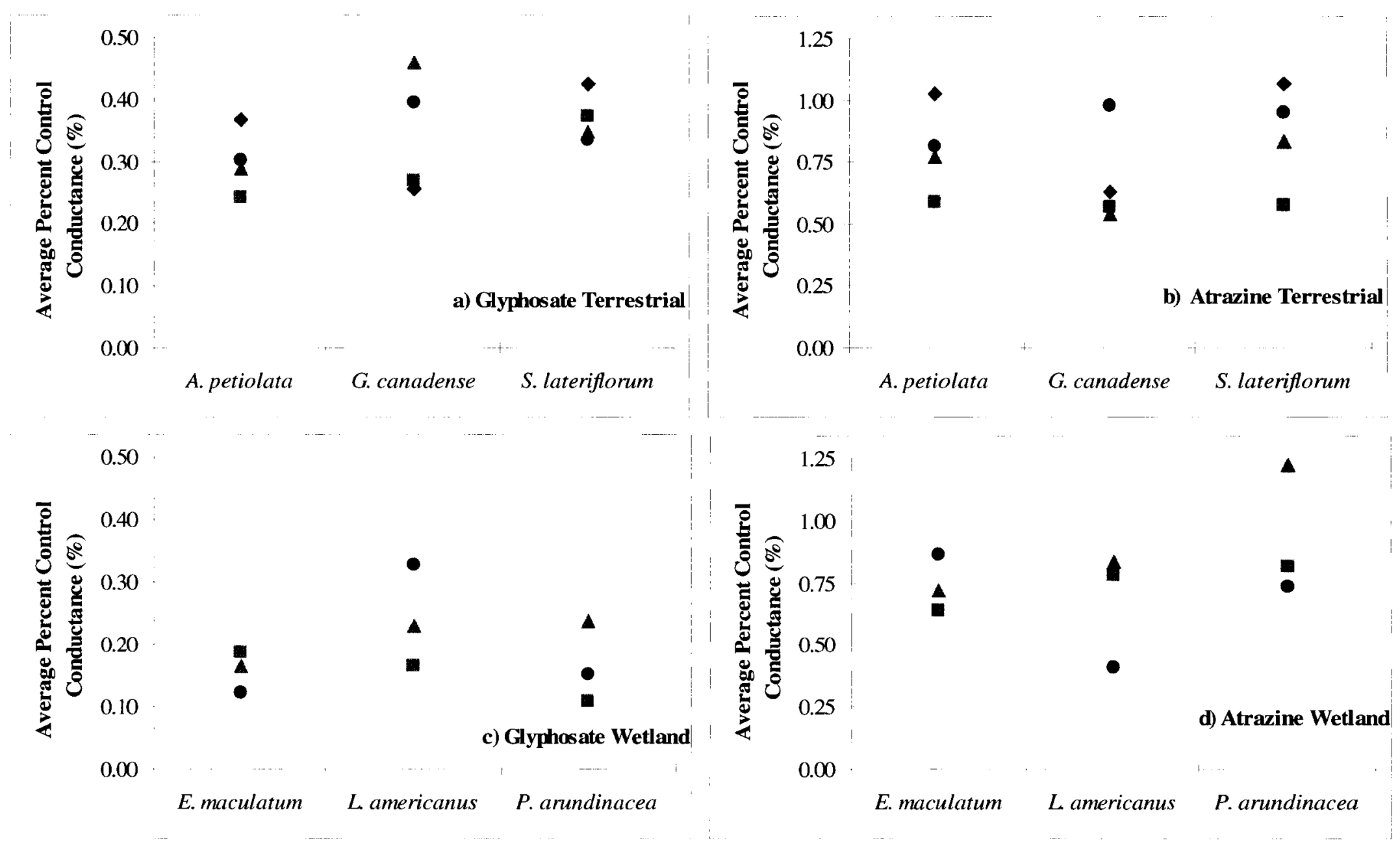

Figure 4.15. Test and species interaction effects on estimated marginal geometric means of percent control conductance at the overall average concentration for each herbicide and habitats type. Measurements were taken seven days after spray. - $\bullet$ - single species test, $-\square$ - greenhouse microcosm tests, - $\mathbf{\Delta}$ - long-term microcosm test, - - outdoor microcosm test. 


\section{CHAPTER 5:}

\section{General Discussion and Conclusions}

\subsection{DISCUSSION}

The main objectives of this study were to compare the response of non-crop species to herbicides when grown singly in pots versus when grown in different microcosm communities. The results of experiments using biomass, chlorophyll fluorescence and stomatal conductance as dependent variables have clearly shown that the response to glyphosate and atrazine differs depending on the test conditions. Greenhouse microcosms were generally the most sensitive test. Definitive single species tests were not necessarily the least sensitive test and more severe herbicidal symptoms were generally observed for single species tests than in microcosms tests established in outdoor semi-natural field conditions or for longer test periods. Validation of methodologies for assessing the risk pesticides pose to non-target terrestrial and wetland plant species is still needed. In 1988, Cairns commented that neither single species nor mesocosm aquatic tests have had data validated in natural systems in a meaningful way. Almost two decades later, little progress in this matter has been made for terrestrial systems.

For all three endpoints, an interesting trend arose. The test conditions, species and herbicide concentrations selected did not have independent effects on a given endpoint. The precise way in which the variables interacted was dependent on the particular species, herbicide and endpoint chosen (Table 5.1). Clearly, the influence of 
these interactions would make extrapolation from a single species test or a simple artificial community to field conditions difficult.

Previous studies have shown that initial choices made in experimental design are paramount to the outcome of an experiment. For example, the effects of herbicides and other chemicals were found to depend strongly on the species present (Blanck, et al., 1984; Marrs, et al., 1991b; Marrs and Frost, 1997; Madsen and Streibig, 2000). Other factors besides species selection have also been shown to affect experimental results. Wilson and Tilman (1993) found that the effect of competition on growth varied due to an interaction between nitrogen fertilization and level of disturbance while BarratSegretain (2005) found that competition was influenced by spatial patterns and initial development. An intricate study by Drake (1991) found that timing, chance and sequential events played an important role in shaping aquatic communities and could result in large differences in community organization.

In terms of pesticide registration, and also risk assessment in general, there are two opposing requirements. On one hand, there is a need for simple standardized tests which can be used for a variety of compounds. On the other hand, there is a need to obtain data which provide a meaningful assessment of the risk posed to an ecosystem. Increasing the scale from; single species tests, to microcosms, to mesocosms, to field studies, will increase the realism but decrease the ability to standardize and replicate. If a system were to incorporate all of the heterogeneity of a natural ecological structure, it would become unique and cease to be a true replicate (Landis, et al., 1997). The community conditioning hypothesis was developed through experimental work with standard aquatic microcosms (SAM) (Matthews, et al., 1996). It states that ecological 
communities are generally not at equilibrium, and retain information about events in their unique history in many abiotic and biotic forms (which may or may not be measurable) (Matthews, et al., 1996).

Interpretation of the results of this study and many others could have been improved by attempting to quantify the unique history of different tests conditions. In particular, a measure of initial biomass and subsequent growth rates would have been valuable and has been proposed as a tool to help identify true treatment effects (Gibson, et al., 1999; Kikvidze, et al., 2006). Furthermore, it has been proposed that single endpoints are of limited value for multi-species tests because they are not strictly repeatable and that pattern analysis with multiple types of measurements should be the focus of pesticide risk assessment (Matthews, et al., 1996; Landis, et al., 1997).

Both the chlorophyll $a$ fluorescence parameter Fv/Fm and stomatal conductance may be useful additional measures in pesticide risk assessment. Both have been shown to be negatively affected by atrazine and glyphosate and provide different measures of the physiological status of a plant. They may also be useful as non-destructive early indicators of pesticide damage or as endpoints. Fv/Fm has a narrower range of response compared to biomass or stomatal conductance and would therefore need to be scaled appropriately. Stomatal conductance measurements are highly variable and therefore it would be difficult to use this measure on its own or without controls. Neither chlorophyll fluorescence nor stomatal conductance should replace biomass as a primary endpoint in phytotoxicity testing.

The microcosm design used in this study, consisting of five doses and a control with six replicates each, was congruent with the single species design outlined in current 
registration guidelines (Holst and Ellwanger, 1982; OECD, 1984; EPA, 1996; OECD, 2005). Theoretically, these types of microcosm tests could be used in the registration process, however without proper validation, a direct link to risk under field conditions would remain unclear. Microcosm experiments, particularly those in controlled greenhouse conditions are extremely useful for measuring a particular factor in isolation and using the results to generate a hypothesis to be tested in the field (Freckleton and Watkinson, 2000). Conversely, they could potentially be used to aid interpretation of patterns observed in the field.

\subsection{CONCLUSIONS}

The response of non-target plants to the herbicides glyphosate and atrazine does generally differ when they are grown singly in pots versus in greenhouse microcosms communities. When $\mathrm{IC}_{25} \mathrm{~S}$ and estimated geometric marginal means from biomass, chlorophyll fluorescence and stomatal conductance data are taken into account, greenhouse microcosms are generally more sensitive than single species tests. Species grown in semi-natural outdoor microcosms, or those established for a longer period of time, are generally less affected compared to single species or greenhouse microcosm tests. Sensitivity to a particular test condition depends strongly on the species selected as well as on interactions between variables including concentration. Single species tests provide useful baseline data regarding the sensitivity of a particular species and aid interpretation of effects at higher levels of biological organization. However, single species tests alone, particularly with crop species, may have limited relevance for assessing risk posed to complex ecological systems. Microcosms are useful tools for 
examining relationships between species, and for generating and validating hypotheses. Stomatal conductance and chlorophyll fluorescence should not replace biomass as an endpoint, but both are useful early indicators of herbicidal damage that may be particularly useful in the field. Further research should focus on the validation of single species and microcosm tests with field-level effects. 
Table 5.1. Summary of general linear model significant main and interaction effects of test condition, species and concentration on percent control biomass, day $7 \mathrm{Fv} / \mathrm{Fm}$ or day 7 stomatal conductance for three terrestrial and three wetland target species treated with atrazine or glyphosate.

\begin{tabular}{|c|c|c|c|c|}
\hline Model & $\begin{array}{l}\text { Glyphosate Terrestrial } \\
\text { Tests }\end{array}$ & $\begin{array}{l}\text { Atrazine Terrestrial } \\
\text { Tests }\end{array}$ & $\begin{array}{l}\text { Glyphosate Wetland } \\
\text { Tests }\end{array}$ & $\begin{array}{l}\text { Atrazine Wetland } \\
\text { Tests }\end{array}$ \\
\hline Test & $\begin{array}{l}\text { Biomass } \\
\text { Chlorophyll Fluorescence }\end{array}$ & $\begin{array}{l}\text { Biomass } \\
\text { Chlorophyll Fluorescence } \\
\text { Stomatal Conductance } \\
\end{array}$ & $\begin{array}{l}\text { Biomass } \\
\text { Stomatal Conductance }\end{array}$ & $\begin{array}{l}\text { Biomass } \\
\text { Chlorophyll Fluorescence }\end{array}$ \\
\hline Species & Biomass & $\begin{array}{l}\text { Biomass } \\
\text { Chlorophyll Fluorescence } \\
\text { Stomatal Conductance } \\
\end{array}$ & $\begin{array}{l}\text { Biomass } \\
\text { Chlorophyll Fluorescence } \\
\text { Stomatal Conductance } \\
\end{array}$ & $\begin{array}{l}\text { Biomass } \\
\text { Stomatal Conductance }\end{array}$ \\
\hline Concentration & $\begin{array}{l}\text { Biomass } \\
\text { Chlorophyll Fluorescence } \\
\text { Stomatal Conductance }\end{array}$ & $\begin{array}{l}\text { Biomass } \\
\text { Chlorophyll Fluorescence } \\
\text { Stomatal Conductance }\end{array}$ & $\begin{array}{l}\text { Biomass } \\
\text { Chlorophyll Fluorescence } \\
\text { Stomatal Conductance }\end{array}$ & $\begin{array}{l}\text { Biomass } \\
\text { Chlorophyll Fluorescence } \\
\text { Stomatal Conductance }\end{array}$ \\
\hline Test* Species & $\begin{array}{l}\text { Biomass } \\
\text { Stomatal Conductance }\end{array}$ & $\begin{array}{l}\text { Biomass } \\
\text { Chlorophyll Fluorescence } \\
\text { Stomatal Conductance } \\
\end{array}$ & $\begin{array}{l}\text { Biomass } \\
\text { Stomatal Conductance }\end{array}$ & $\begin{array}{l}\text { Biomass } \\
\text { Stomatal Conductance }\end{array}$ \\
\hline $\begin{array}{l}\text { Test* } \\
\text { Concentration }\end{array}$ & Biomass & $\begin{array}{l}\text { Biomass } \\
\text { Chlorophyll Fluorescence } \\
\text { Stomatal Conductance }\end{array}$ & $\begin{array}{l}\text { Biomass } \\
\text { Stomatal Conductance }\end{array}$ & \\
\hline $\begin{array}{l}\text { Species* } \\
\text { Concentration }\end{array}$ & $\begin{array}{l}\text { Biomass } \\
\text { Chlorophyll Fluorescence }\end{array}$ & $\begin{array}{l}\text { Biomass } \\
\text { Chlorophyll Fluorescence } \\
\text { Stomatal Conductance }\end{array}$ & $\begin{array}{l}\text { Biomass } \\
\text { Chlorophyll Fluorescence } \\
\text { Stomatal Conductance }\end{array}$ & Stomatal Conductance \\
\hline $\begin{array}{l}\text { Test* Species * } \\
\text { Concentration }\end{array}$ & & $\begin{array}{l}\text { Biomass } \\
\text { Chlorophyll Fluorescence } \\
\text { Stomatal Conductance }\end{array}$ & & Stomatal Conductance \\
\hline
\end{tabular}




\section{REFERENCES}

Abbaspoor, M., Teicher, H.B. and Streibig, J.C. 2006. The effect of root-absorbed PSII inhibitors on Kautsky curve parameters in sugar beet. Weed Res. 46: 226-235.

Baird, D.D., Upchurch, R.P., Homesley, W.B. and Franz, J.E. 1971. Introduction of a new broadspectrum postemergence herbicide class with utility for herbaceous perennial weed control. Proc. North Cent. Weed Control Conf. 27: 13-20.

Barbagallo, R.P., Oxborough, K., Pallett, K.E. and Baker, N.R. 2003. Rapid, noninvasive screening for perturbations of metabolism and plant growth using chlorophyll fluorescence imaging. Plant Physiol. 132: 485-493.

Barrat-Segretain, M.-H. 2005. Competition between invasive and indigenous species: impact of spatial pattern and developmental stage. Plant Ecol. 180: 153-160.

Björkman, O. and Demmig, B. 1987. Photon yield of $\mathrm{O}_{2}$ evolution and chlorophyll fluorescence characteristics at $77 \mathrm{~K}$ among vascular plants of diverse orgins. Planta. 170: 489-504.

Blanck, H., Wallin, G. and Wängberg, S.-A. 1984. Species-dependent variation in algal sensitivity to chemical compounds. Ecotox. Environ. Safe. 8: 339-351.

Boatman, N.D., Blake, K.A., Aebischer, N.J. and Sotherton, N.W. 1994. Chapter 5: Factors Affecting the Herbaceous Flora of Hedgerows on Arable Farms and its Value as Wildlife Habitat. In: Hedgerow Management and Nature Conservation. Edited by: T.A. Watt and G.P. Buckley. Wye College Press, Wye. pp. 33-46.

Boutin, C. 2006. Comparison of the vegetation and seedbanks of soybean fields, adjacent boundaries, and hedgerows in Ontario. Can. J. Plant Sci. 85: 557-567.

Boutin, C and Jobin, B. 1998. Intensity of agricultural practices and effects on adjacent habitats. Ecol. Appl. 8(2): 544-557.

Boutin, C. and Rogers, C.A. 2000. Pattern of Sensitivity of Plant Species to Various Herbicides- An Analysis with Two Databases. Ecotoxicology. 9: 255-271.

Boutin, C. Jobin, B. and Bélanger, L. 2003. Importance of riparian habitats to flora conservation in farming landscapes of southern Québec, Canada. Agr. Ecosyst. Environ. 94: 73-87.

Boutin, C., Jobin, B. and Desgranges, J.-L. 1994. Modifications of field margins and other habitats in agricultural areas of Québec, Canada, and effects on plants and birds. BCPC Monograph No. 58: Field Margins: Integrating Agriculture and Conservation. pp.139-144. 
Boutin, C., Lee, H.-B., Peart, E.T., Batchelor, P.S. and Maguire, R.J. 2000. Effects of the sulfonylurea herbicide metsulfuron methyl on growth and reproduction of five wetland and terrestrial plant species. Environ. Toxicol. Chem. 19(10): 2532-2541.

Bowyer, J.R., Camilleri, P. and Vermaas, F.J. 1991. Photosystem II and its interactions with herbicides. In: Topics in Photosynthesis, Volume 10: Herbicides. Edited by: N.R. Baker and M.P. Percival. Elsevier Science Publishers B.V. Amsterdam, the Netherlands.

Bragg, T., Webb, N., Spencer, R., Wood, J., Nicholl, C. and Potter, E. 2004. Delta-T Devices AP4 Porometer User Manual. Edited by N. Webb. Delta-T Devices, Cambridge, England. Document AP4-UM-3.

Brecke, B.J. and Duke, W.B. 1980. Effect of glyphosate on intact bean plants (Phaseolus vulgaris L.). Plant Physiol. 66: 656-659.

Breeze, V.G., Thomas, G. and West, C.J. 1990. Effects of herbicides: Dose response and spray drift modeling. In: Pesticide Drift and Impact. Ed. B.N.K. Davis, NERC contract Report to DOE/NCC, Institute of Terrestrial Ecology, Huntingdon. pp. 55105.

Cairns, J., Jr. 1988. Putting the Eco in Ecotoxicology. Regul. Toxicol. Pharm. 8: 226-238.

Caseley, J. and Copping, L. 2000. Introduction: Twenty-five years of increasing glyphosate use: the opportunities ahead. Pest. Mang. Sci. 56: 297.

Cechin, I., Rossi, S.C., Oliveira, V.C. and Fumis, T.F. 2006. Photosynthetic responses and proline content of mature and young leaves of sunflower plants under water deficit. Photosynthetica. 44(1): 143-146.

Cechin, I., Rossi, S.C., Oliveira, V.C. and Fumis, T.F. 2006. Photosynthetic responses and proline content of mature and young leaves of sunflower plants under water deficit. Photosynthetica. 44(1): 143-146.

Christensen, M.G., Teicher, H.B. and Streibig, J.C. 2003. Linking fluorescence induction curve and biomass in herbicide screening. Pest Mang. Sci. 59: 1303-1310.

Clark, J., Ortego, L.S. and Fairbrother, A. 2004. Sources of variability in plant toxicity testing. Chemosphere. 57: 1599-1612.

Clarke, J.M. and Clarke, F.R. 1996. Considerations in design and analysis of experiments to measure stomatal conductance of wheat. Crop Sci. 36: 1401-1405.

Conrad, R., Büchel, C., Wilhelm, C., Arsalane, W., Berkaloff, C. and Duval, J.-C. 1993. Changes in yield of in-vivo fluorescence of chlorophyll a as a tool for selective herbicide monitoring. J. Appl. Phycol. 5: 505-516. 
Davies, W.J. 1977. Stomatal responses to water stress and light in plants grown in controlled environmental and in the field. Crop Sci. 17: 735-740.

Davies, W.J. and Blackman, P.G. 1989. Growth and development of plants in controlled environments and in the field. Aspects Appl. Biol. 21: 1-12.

de Snoo, G.R. 1999. Unsprayed field margins: effects on environment, biodiversity and agricultural practice. Landscape Urban Plan. 46: 151-160.

de Snoo, G.R. and van der Poll, R.J. 1999. Effect of herbicide drift on adjacent boundary vegetation. Agr. Ecosyst. Environ. 73: 1-6.

DeEll, J.R. and Toivonen, P.M.A. Editors. 2003. Practical Applications of Chlorophyll Fluorescence in Plant Biology. Kluwer Academic Publishers. Norwell, MA, USA. pp. 259.

Deschênes, M., Bélanger, L. and Giroux, J.F. 2003. Use of farmland riparian strips by declining and crop damaging birds. Agr. Ecosyst. Environ. 95: 567-577.

Drake, J.A. 1991. Community-assembly mechanics and the structure of an experimental species ensemble. Am. Nat. 137(1): 1-26.

Dubey, P.S. 1984. Laboratory Microecosystem Models: New Tools to Study the Toxicant Behaviour in the Ecosystem. Proc. Sem. Eff. Pest. Aq. Fau. pp. 175-184.

Duelli, P. 1997. Biodiversity evaluation in agricultural landscapes: An approach at two different scales. Agr. Ecosyst. Environ. 62: 81-91.

Environment Canada. 2005. Guidance Document on Statistical Methods for Environmental Toxicity Tests. Environment Canada, Ottawa, ON, Canada. pp 241.

EPA (United States Environmental Protection Agency). 1993. R.E.D. FACTS. Glyphosate. Prevention, Pesticides And Toxic Substances (7508W). EPA-738-F-93011. http://www.epa.gov/oppsrrd 1/REDs/factsheets/0178fact.pdf.

EPA (United States Environment Protection Agency). 1996. Ecological Effects Test Guidelines. OPPTS 850.400. Background- Nontarget Plant Testing- Public Draft. EPA-712-C-96-151. http://www.epa.gov/opptsfrs/publications/OPPTS_Harmonized/850_Ecological_Effe cts Test Guidelines/Drafts/850-4000.pdf.

EPA (United States Environmental Protection Agency). January 2003. Atrazine I.R.E.D. http://www.epa.gov/oppsrrd l/REDs/atrazine ired.pdf

Ferrel, J.A., Earl, H.J. and Vencill, W.K. 2003. The effect of selected herbicides on $\mathrm{CO}_{2}$ assimilation, chlorophyll fluorescence, and stomatal conductance in johnsongrass (Sorghum halepense L.). Weed Sci. 51: 28-31. 
Ferrell, J.A. and Vencill, W.K. 2004. Duration of yellow nutsedge (Cyperus esculentus) competitiveness after herbicide treatment. Weed Sci. 52: 24-27.

Ferrell, J.A., Earl, H.J. and Vencill, W.K. 2003. The effect of selected herbicides on $\mathrm{CO}_{2}$ assimilation, chlorophyll fluorescence, and stomatal conductance in johnsongrass (Sorghum halepense L.). Weed Sci. 51: 28-31.

Fischer, R.A., Rees, D., Sayre, K.D., Lu, Z.M., Condon, A.G. and Saavedra, A.L. 1998. Wheat yield progress associated with higher stomatal conductance and photosynthetic rate, and cooler canopies. Crop Sci. 38: 1467-1475.

Fletcher, J.S., Johnson, F.L. and McFarlane, J.C. 1990. Influence of greenhouse versus field testing and taxonomic differences on plant sensitivity to chemical treatment. Environ. Toxicol. Chem. 9: 769-776.

Fletcher, J.S., Pfleeger, T.G., Ratsch, H.C. and Hayes, R. 1996. Potential impact of low levels of chlorsulfuron and other herbicides on growth and yield of nontarget plants. Environ. Toxicol. Chem. 15(7): 1189-1196.

Follak, S.and Hurle, K. 2003. Effect of airborne bromoxynil-octanoate and metribuzin on non-target plants. Environ. Pollut. 126: 139-146.

Force, L., Critchley, C. and van Rensen, J.J.S. 2003. New fluorescence parameters for monitoring photosynthesis in plants. Photosynth. Res. 78: 17-33.

Franzaring, J., Kempenaar, C. and van der Eerden, L.J.M. 2001. Effects of vapours of chlorpropham and ethofumesate on wild plant species. Environ. Pollut. 114: 21-28.

Fraser, L.H. and Keddy, P. 1997. The role of experimental microcosms in ecological research. TREE 12(12): 478-481.

Freckleton, R.P. and Watkinson, A.R. 2000. Designs for greenhouse studies of interactions between plants: an analytical perspective. J. Ecol. 88: 386-391.

Freemark, K. and Boutin, C. 1995. Impacts of agricultural herbicide use on terrestrial wildlife in temperate landscapes: A review with special reference to North America. Agr. Ecosyst. Environ. 52: 67-91.

Garrod, J.F. 1989. Comparative responses of laboratory and field grown test plants to herbicides. Aspects Appl. Biol. 21: 51-62.

Geiger, D.R., Shieh, W.-J. and Fuchs, M.A. 1999. Causes of self-limited translocation of glyphosate in Beta vulgaris plants. Pestic. Biochem. Phys. 64: 124-133.

Gibson, D.J., Connolly, J., Hartnett, D.C. and Weidenhamer, J.D. 1999. Designs for greenhouse studies of interactions between plants. Ecology. 87: 1-16. 
Gillett, J.W., Witt, J.M. and Wyatt, C.J. Editors. 1977. Terrestrial Microcosms. Proceedings of the Workshop on Terrestrial Microcosms. Symposium on Terrestrial Microcosms and Environmental Chemistry. 35 pp.

Gleason, H.A. and Cronquist, A. 1991. Manual of Vascular Plants of Northeastern United States and Adjacent Canada. $2^{\text {nd }}$ Edition. The New York Botanical Garden, Bronx, New York, USA.

Govindjee. 1995. Sixty-three years since Kautsky: Chlorophyll $a$ Fluorescence. Aust. J. Plant Physiol. 22: 131-160.

Grime, J.P. 1993. Ecology sans frontières. In: Fraser, L.H. and Keddy, P. 1997. The role of experimental microcosms in ecological research. TREE 12(12): 478-481.

Harbinson, J. and Rosenqvist, 2003. An introduction to chlorophyll fluorescence. In: Practical Applications of Chlorophyll Fluorescence in Plant Biology. Edited by: J.R. DeEll and P.M.A. Toivonen. Kluwer Academic Publishers, Norwell, Massachusetts, USA.

Hernando, F., Royuela, M., Muňoz-Rueda, A. and Gonzalez-Murua, C. 1989. Effect of glyphosate on the greening process and photosynthetic metabolism in Chlorella pyrenoidosa. J. Plant Physiol. 134: 26-31.

Holst, R.W. and Ellwanger, T.C. 1982. Pesticide assessment guidelines, Subdivision J, Hazard evaluation: Non-target. EPA 540/9-82-020. USA Environmental Protection Agency. Washington, D.C., USA.

Ivanova, A., Stefanov, K. and Yordanov, I. 1999. Effect of the herbicide atrazine on the bean leaf lipids. Biol. Plantarum. 42(3): 417-422.

Jackson, D.A. 1993. Stopping rules in principal components analysis: a comparison of heuristic and statistical approaches. Ecology. 74: 2204-2214.

Kaňa, R., Špundová, M., Ilík, P. Lazár, D., Klem, K., Tomek, P., Nauš, J. and Prášil, O. 2004. Effect of herbicide clomazone on photosynthetic processes in primary barley (Hordeum vulgare L.) leaves. Pestic. Biochem. Phys. 78: 161-170.

Kautsky, H. and Hirsch, A. 1931. Neue versuche zur kohlensäureassimilation. Naturwissen. 19: 964.

Keddy, P.A. 2001. Competition. $2^{\text {nd }}$ edition. Kluwer Academic Publishers, Dordrecht. $552 \mathrm{pp}$.

Kersting, K. 1982. Micro-ecosystems for testing effects of toxic substances. In: Annual Report 1981. Jaarverslag. Research Institute for Nature Management. pp. 75-85. 
Kikvidze, Z., Armas, C. and Pugnaire, F.I. 2006. The effect of initial biomass in manipulative experiments on plants. Funct. Ecol. 20: 1-3.

Kim, H., Goins, G.D., Wheeler, R.M. and Sager, J.C. 2004. Stomatal conductance of lettuce grown under or exposed to different light qualities. Ann. Bot.- London 94: 691-697.

Kjaer, C., Pederson, M.B. and Elmegaard, N. 1998. Effects of Soil Copper on Black Bindweed (Fallopia convolvulus) in the Laboratory and in the Field. Arch. Environ. Contam. Toxicol. 35: 14-19.

Kjaer, C., Pederson, M.B. and Elmegaard, N. 1998. Effects of Soil Copper on Black Bindweed (Fallopia convolvulus) in the Laboratory and in the Field. Arch. Environ. Contam. Toxicol. 35: 14-19.

Kleijn, D. and Snoeijing, I.J. 1997. Field Boundary Vegetation and the Effects of Agrochemical Drift: Botanical Change Caused by Low Levels of Herbicide and Fertilizer. J. Appl. Ecol. 34(6): 1413-1425.

Korres, N.E., Froud-Williams, R.J. and Moss, S.R. 2003. Chlorophyll fluorescence technique as a rapid diagnostic test of the effects of the photosynthetic inhibitor chlorotoluron on two winter wheat cultivars. Ann. Appl. Biol. 143: 53-56.

Krause, G.H. and Weis, E. 1984. Chlorophyll fluorescence as a tool in plant physiology. II. Interpretation of fluorescence signals. Photosynth. Res. 5: 139-157.

Krause, G.H. and Weis, E. 1991. Chlorophyll fluorescence and photosynthesis: The basics. Annu. Rev. Plant Physiol. Plant Mol. Biol. 42: 313-349.

Krugh, B.W. and Miles, D. 1996. Monitoring the effects of five "nonherbicidal" pesticide chemicals on terrestrial plants using chlorophyll fluorescence. Environ. Toxicol. Chem. 15(4): 495-500.

Lagerlöf, J., Stark, J. and Svensson, B. 1992. Margins of agricultural fields as habitats for pollinating insects. Agr. Ecosyst. Environ. 40: 117-124.

Landis, W.G., Matthews, R.A. and Matthews, G.B. 1997. Design and analysis of multispecies toxicity tests for pesticide registration. Ecol. Appl. 7(4): 1111-1116.

Larsen, D.P., DeNoyelles, F., Jr., Stay, F. and Shiroyama, T. 1986. Comparisons of single-species, microcosm and experimental pond responses to atrazine exposure. Environ. Toxicol. Chem. 5: 179-190.

Lazár, D. 1999. Chlorophyll $a$ fluorescence induction. Biochim. Biophys. Acta. 1412: 128. 
Lichtenthaler, H.K. 1996. Vegetative Stress: An introduction to the stress concept in plants. J. Plant Physiol. 148: 4-14.

Lichtenthaler, H.K. and Rinderle, U. 1988. The role of chlorophyll fluorescence in the detection of stress conditions in plants. CRC Cr. Rev. Anal. Chem. 19(S1): S29: S85.

Madsen, K.H. and Streibig, J.C. 2000. Simulating weed management in glyphosatetolerant crops: greenhouse and field studies. Pest Manag. Sci. 56: 340-344.

Matthews, R.A., Landis, W.G. and Matthews, G.B. 1996. The community conditioning hypothesis and its application to environmental toxicology. Environ. Toxicol. Chem. 15(4): 597-603.

Marrs, R.H. and Frost, A.J. 1997. A Microcosm Approach to the Detection of the Effects of Herbicide Spray Drift in Plant Communities. J. Environ. Manag. 50: 369-388.

Marrs, R.H., Frost, A.J. and Plant, R.A. 1991a. Effects of Herbicide Spray Drift on Selected Species of Nature Conservation Interest: The Effects of Plant Age and Surrounding Vegetation Structure. Environ. Pollut. 69: 223-225.

Marrs, R.H., Frost, A.J. and Plant, R.A. 1991b. Effect of Mecoprop Drift on Some Species of Conservation Interest when Grown in Standardized Mixtures in Microcosms. Environ. Pollut. 73: 25-42.

Marrs, R.H., Frost, A.J., Plant, R.A. and Lunnis, P. 1992. Aerial applications of asulam: A bioassay technique for assessing buffer zones to protect sensitive sites in upland Britain. Biol. Conserv. 59: 19-23.

Marrs, R.H., Williams, C.T., Frost, A.J. and Plant, R.A. 1989. Assessment of the Effects of Herbicide Spray Drift on a Range of Plant Species of Conservation Interest. Environ. Pollut. 58: 71-86.

Marshall, E.J.P. 2001. Biodiversity, herbicides and non-target plants. BCPC ConferenceWeeds. pp. 855-862.

McGee, B., Berges, H. and Callow, K. 2004. Survey of pesticide use in Ontario, 2003: Estimates of pesticides used on field crops, fruit and vegetable crops, and other agricultural crops. Ontario Ministry of Agriculture and Food, Guelph, Ontario, Canada. ISBN 0-7743-9959-7.

Messinger, S.M., Buckley, T.N. and Mott, K.A. 2006. Evidence for involvement of photosynthetic processes in stomatal response to $\mathrm{CO}_{2}$. Plant Physiol. 140: 771-778.

Monsanto Canada, Inc. 2001. Roundup® Original. Product Label. 
Monsanto Company. 2002. Backgrounder: History of Monsanto's Glyphosate Herbicides.http://www.monsanto.com/monsanto/content/products/productivity/round up/back history.pdf.

Monteith, J.L. 1980. Principles of Environmental Physics. In: Bragg, T., Webb, N., Spencer, R., Wood, J., Nicholl, C. and Potter, E. 2004. Delta-T Devices AP4 Porometer User Manual. Edited by N. Webb. Delta-T Devices, Cambridge, England. Document AP4-UM-3.

Monteith, J.L., Campbell, G.S. and Potter, E.A. 1988. Theory and performance of a dynamic diffusion porometer. Agr. Forest Meteorol. 44: 27-38.

Newcomb, L. 1977. Newcomb's Wildflower Guide. Little, Brown and Company, Boston, Massachusetts, USA.

OECD (Organization for Economic Cooperation and Development). 1984. Terrestrial Plants, Growth Test \#208.OECD Guidelines for Testing Chemicals. Paris, France.

OECD (Organization for Economic Cooperation and Development). 2005. Terrestrial Plants, Growth Test \#208 and \#227. OECD Guidelines for Testing Chemicals. Paris, France.

Papageorgiou, G. 1975. Chlorophyll fluorescence: An intrinsic probe of photosynthesis. In: Bioenergetics of Photosynthesis. Edited by: E. Govindjee. Academic Press, Inc., New York, USA. 319-365.

Parkinson, K.J. 1985. Porometry. In: Instrumentation for Environmental Physiology. Edited by: B. Marshall and F.I. Woodward. Cambridge University Press, Cambridge.

Patterson, D.T., Bunce, J.A., Alberte, R.S. and Van Volkenburgh, E. 1977. Photosynthesis in relation to leaf characteristics of cotton from controlled and field environments. Plant Physiol. 59: 384-387.

Pereira, W.E., de Siqueira, D.L., Martinez, C.A. and Puiatti, M. 2000. Gas exchange and chlorophyll fluorescence in four citrus rootstocks under aluminum stress. J. Plant Physiol. 157: 513-520.

Pfleeger, T. and Zobel, D. 1995. Organic pesticide modification of species interactions in annual plant communities. Ecotoxicology. 4: 15-37.

Quarrie, S.A. and Jones, H.G. 1977. Effects of abscisic acid and water stress on development and morphology of wheat. J. Exp. Bot. 28(102): 192-203.

Ralph, P.J. 2000. Herbicide toxicity of Halophila ovalis assessed by chlorophyll $a$ fluorescence. Aquat. Bot. 66: 141-152. 
Reuter, S., Siemoneit, S., Höllrigl-Rosta, A. and Schulte. 2006. Extended method for assessing the risk to terrestrial non-target plants exposed to plant protection products. SETAC Europe $16^{\text {th }}$ Annual Meeting. The Hague, Netherlands. TU1/Y1/P06.

Roháček, K. and Barták, M. 1999. Technique of the modulated chlorophyll fluorescence: basic concepts, useful parameters, and some applications. Photosynthetica. 37(3): 339-363.

Rosenquist, E. and van Kooten, O. 2003. Chlorophyll Fluorescence: A general description and nomenclature. In: Practical Applications of Chlorophyll Fluorescence in Plant Biology. Edited by: J.R. DeEll and P.M.A. Toivonen. Kluwer Academic Publishers, Norwell, Massachusetts, USA.

Schreiber, U. 1983. Chlorophyll fluorescence yield changes as a tool in plant physiology I. The measuring system. Photosynth. Res. 4: 361-373.

Schreiber, U., Schliwa, U. and Bilger, W. 1986. Continuous recording of photochemical and non-photochemical chlorophyll fluorescence quenching with a new type of modulation fluorometer. Photosynth. Res. 10: 51-62.

Sharma, S.D. and Singh, M. 2001. Environmental factors affecting absorption and bioefficacy of glyphosate in Florida beggarweed (Desmodium tortuosum). Crop Prot. 20: 511-516.

Silletti, A.M., Knapp, A.K. and Blair, J.M. 2004. Competition and coexistence in grassland codominants: responses to neighbour removal and resource availability. Can. J. Bot. 82: 450-460.

Smith, M. and Moss, J.S. 1998. An experimental investigation, using stomatal conductance and fluorescence, of the flood sensitivity of Boltonia decurrens and its competitors. J. Appl. Ecol. 35: 553-561.

Smith, M. and Moss, J.S. 1998. An experimental investigation, using stomatal conductance and fluorescence, of the flood sensitivity of Boltonia decurrens and its competitors. J. Appl. Ecol. 35: 553-561.

Snel, J.F.H., Vos, J.H., Gylstra, R. and Brock, T.C.M. 1998. Inhibition of photosystem II (PSII) electron transport as a convenient endpoint to assess stress of the herbicide linuron on freshwater plants. Aquat. Ecol. 32: 113-123.

Sotherton, N.W., Dover, J.W. and Rands, M.R.W. 1988. The effects of pesticide exclusion strips on faunal populations in Great Britain. Ecol. Bull. 39: 197-199.

Statistics Canada. 1981-2001 Censuses of Agriculture. Total area of farms, land tenure and land in crops, by provinces. http://www.statcan.ca/english/Pgdb/agrc25a.htm. 
Statistics Canada. 2001 Census of Agriculture: Applications to the land, by Provinces. http://www.statcan.ca/english/Pgdb/agrc05g.htm.

Stephenson, G.L., Koper, N., Atkinson, G.F., Solomon, K.R. and Scroggins, R.P. 2000. Use of nonlinear regression techniques for describing concentration-response relationships of plant species exposed to contaminated site soil. Environ. Toxicol. Chem. 19: 2968-2981.

Sutherland, S. 2004. What makes a weed a weed: life history traits of native and exotic plants in the USA. Oecologia. 141: 24-29.

Syngenta Crop Protection Canada, Inc. 2002. AAtrex® Liquid 480. Product Label.

Taiz, L. and Zeiger, E. 2002. Plant Physiology. Third Edition. Sinauer Associates, Inc. Publishers. Sunderland, MA, USA

Tomlin, C.D.S. (Editor). 2000. The Pesticide Manual. 12 ${ }^{\text {th }}$ Edition. British Crop Protection Council, Surrey, England.

USDA (United States Department of Agriculture), 2006. Plants Database. http://plants.usda.gov/index.html.

Verhoef, A. 1997. The effect of temperature differences between porometer head and leaf surfaces on stomatal conductance measurements. Plant Cell Environ. 20: 641-646.

White A.L. 2006. Protecting non-target plant species: Suggested improvements to current pesticide registration guidelines. M.Sc. thesis, Carleton University, Ottawa, ON, Canada.

Wilson, S.D. and Tilman, D. 1993. Plant competition and resource availability in response to disturbances and fertilization. Ecology. 74(2): 599-611.

Wong, S.C., Cowan, I.R. and Farquhar, G.D. 1979. Stomatal conductance correlates with photosynthetic capacity. Nature. 282: 424-426.

Woodburn, A.T. 2000. Glyphosate: production, pricing and use worldwide. Pest Manag. Sci. 56: 309-312.

Xia, X.J., Huang, Y.Y., Wang, L., Huang, L.F., Yu, Y.L., Zhou, Y.H. and Yu, J.Q. 2006. Pesticides-induced depression of photosynthesis was alleviated by 24-epibrassinolide pretreatment in Cucumis sativus L. Pestic. Biochem. Phys. 86: 42-48.

Zheleva, D., Tsonev, T., Sergiev, I. and Karanov, E. 1994. Protective effect of exogenous polyamines against atrazine in pea plants. J. Plant Growth Regul. 13: 203-211. 
APPENDIX 1. Germination requirements, growth conditions, number of days of growth until testing stage and number of leaves at testing stage for terrestrial and wetland non-crop plants. Requirements were determined through pilot studies conducted between September and June 2004 as directions from seed suppliers were often incomplete or did not result in high rates of germination.

\begin{tabular}{|c|c|c|c|c|c|}
\hline Terrestrial Species & Stratification & $\begin{array}{l}\text { Temperature requirements } \\
\text { for germination }\end{array}$ & Other treatments & $\begin{array}{l}\sim \text { Days } \\
\text { until test } \\
\text { stage }\end{array}$ & $\begin{array}{l}\text { Leaf } \\
\text { number at } \\
\text { testing }\end{array}$ \\
\hline Alliaria petiolata & N/A & $\begin{array}{l}\text { Requires a variable } \\
\text { temperature with a low } \\
\text { night-time temperature (e.g. } \\
\left.5-25^{\circ} \mathrm{C}\right)\end{array}$ & $\begin{array}{l}\text { Scarify seeds and soak for } 24 \\
\text { hours in } 500 \mathrm{ppm} \text { giberellic } \\
\text { acid. Cover seeds with 3-5 mm } \\
\text { of Promix }\end{array}$ & 45 & 4 \\
\hline Euthamia graminifolia & Minimum 1 month at $0-4^{\circ} \mathrm{C}$ & N/A & N/A & 56 & 15 \\
\hline Fragaria virginiana & $\mathrm{N} / \mathrm{A}$ & $\begin{array}{l}\text { Prefers warm daytime } \\
\text { temperatures }\left(\text { e.g. } 25^{\circ} \mathrm{C}\right)\end{array}$ & N/A & 50 & 5 \\
\hline Geum canadense & $\begin{array}{l}1 \text { month at } 0-4^{\circ} \mathrm{C} \text { (no more } \\
\text { then } 2 \text { months) }\end{array}$ & N/A & N/A & 47 & 7 \\
\hline Leucanthemum vulgare & N/A & N/A & N/A & 42 & 11 \\
\hline Rudbeckia hirta & N/A & N/A & N/A & 43 & 6 \\
\hline Solidago rugosa & $\begin{array}{l}\text { Minimum } 1 \text { month } \\
\text { at } 0-4^{\circ} \mathrm{C}\end{array}$ & N/A & N/A & 50 & 8 \\
\hline $\begin{array}{l}\text { Symphyotrichum } \\
\text { lateriflorum }\end{array}$ & Minimum 1 month at $0-4^{\circ} \mathrm{C}$ & N/A & N/A & 51 & 8 \\
\hline $\begin{array}{l}\text { Symphyotrichum novae- } \\
\text { angliae }\end{array}$ & Minimum 1 month at $0-4^{\circ} \mathrm{C}$ & N/A & N/A & 44 & 10 \\
\hline
\end{tabular}




\begin{tabular}{|c|c|c|c|c|c|}
\hline Wetland Species & Stratification & $\begin{array}{l}\text { Temperature requirements } \\
\text { for germination }\end{array}$ & Other treatments & $\begin{array}{l}\text { Days } \\
\text { until test } \\
\text { stage }\end{array}$ & $\begin{array}{l}\text { Leaf } \\
\text { number at } \\
\text { test stage }\end{array}$ \\
\hline Asclepias incarnata & Minimum 1 month at $0-4^{\circ} \mathrm{C}$ & $\mathrm{N} / \mathrm{A}$ & $\begin{array}{l}\text { Stratify and germinate in } \\
\text { vermiculite }\end{array}$ & 28 & 8 \\
\hline Chelone glabra & Minimum 1 month at $0-4^{\circ} \mathrm{C}$ & $\begin{array}{l}\text { Prefers variable } \\
\left.\text { temperature (e.g. } 15-25^{\circ} \mathrm{C}\right)\end{array}$ & $\begin{array}{l}\text { Stratify in vermiculite, cover } \\
\text { seeds with vermiculite to } \\
\text { germinate }\end{array}$ & 56 & 10 \\
\hline Eupatorium maculatum & $\begin{array}{l}\text { Minimum } 1 \text { month at } 0-4^{\circ} \mathrm{C} \\
\text { or } 5-10^{\circ} \mathrm{C}\end{array}$ & $\begin{array}{l}\text { Prefers variable } \\
\left.\text { temperature (e.g. } 15-25^{\circ} \mathrm{C}\right)\end{array}$ & N/A & 32 & 8 \\
\hline Eupatorium perfoliatum & $\begin{array}{l}\text { Minimum } 1 \text { month at } 0-4^{\circ} \mathrm{C} \\
\text { or } 5-10^{\circ} \mathrm{C}\end{array}$ & $\begin{array}{l}\text { Prefers variable } \\
\left.\text { temperature (e.g. } 15-25^{\circ} \mathrm{C}\right)\end{array}$ & N/A & 38 & 8 \\
\hline Lycopus americanus & N/A & $\mathrm{N} / \mathrm{A}$ & N/A & 40 & 10 \\
\hline Phalaris arundinacea & $\begin{array}{l}\text { Minimum } 2 \text { months at } 0- \\
4^{\circ} \mathrm{C} \text { needed for fresh seeds, } \\
\text { no stratification needed for } \\
\text { mature seeds }\end{array}$ & $\mathrm{N} / \mathrm{A}$ & N/A & 26 & 6 \\
\hline Verbena hastata & $\begin{array}{l}1 \text { month at } 5-10^{\circ} \mathrm{C} \text { (will not } \\
\text { germinate if stratified at } \\
\text { lower temperatures) }\end{array}$ & $\begin{array}{l}\text { Requires variable } \\
\text { temperature with a low } \\
\text { night-time temperature (e.g. } \\
10-25^{\circ} \mathrm{C} \text { ) }\end{array}$ & N/A & 32 & 8 \\
\hline
\end{tabular}


APPENDIX 2. Visual rating system used to assess herbicidal damage to nine terrestrial and seven wetland plant species 28 days following exposure to $1,10,25,50,75$ or $100 \%$ of the recommended label rate of Roundup $®$ Original (glyphosate) or AAtrex ${ }^{\circledR}$ Liquid 480 (atrazine).

\begin{tabular}{|c|c|c|c|}
\hline Rating & Range (\%) & Mid-point (\%) & Description \\
\hline 0 & 0 & 0 & No effect \\
\hline 1 & $1-5$ & 3 & Trace effect; generally associated with slight growth stimulation \\
\hline 2 & $6-15$ & 10.5 & Slight effect; slight reduction in biomass or discolouration of leaves \\
\hline 3 & $16-29$ & 22.5 & Moderate effect; plants $75 \%$ of the control plants \\
\hline 4 & $30-44$ & 37 & $\begin{array}{l}\text { Injury; plants more than } 50 \% \text { of the controls but with clear, visible injury on leaves } \\
\text { and stems }\end{array}$ \\
\hline 5 & $45-64$ & 54.5 & $\begin{array}{l}\text { Definite injury; plants half the size of the control, leaf epinasty, plant parts } \\
\text { deformed and discoloured }\end{array}$ \\
\hline 6 & $65-79$ & 72 & $\begin{array}{l}\text { Herbicidal effect; plants } 25 \% \text { of the size of the controls, leaf epinasty, plant parts } \\
\text { deformed and discoloured }\end{array}$ \\
\hline 7 & $80-90$ & 85 & $\begin{array}{l}\text { Strong herbicidal effect; plants are very small, leaf epinasty, plant parts deformed } \\
\text { and discoloured }\end{array}$ \\
\hline 8 & $91-99$ & 95 & Approaching kill; only a few green parts left \\
\hline 9 & 100 & 100 & Complete kill \\
\hline
\end{tabular}


APPENDIX 3. Standard planting arrangement used for terrestrial and wetland microcosms. Target species are indicated in bold.
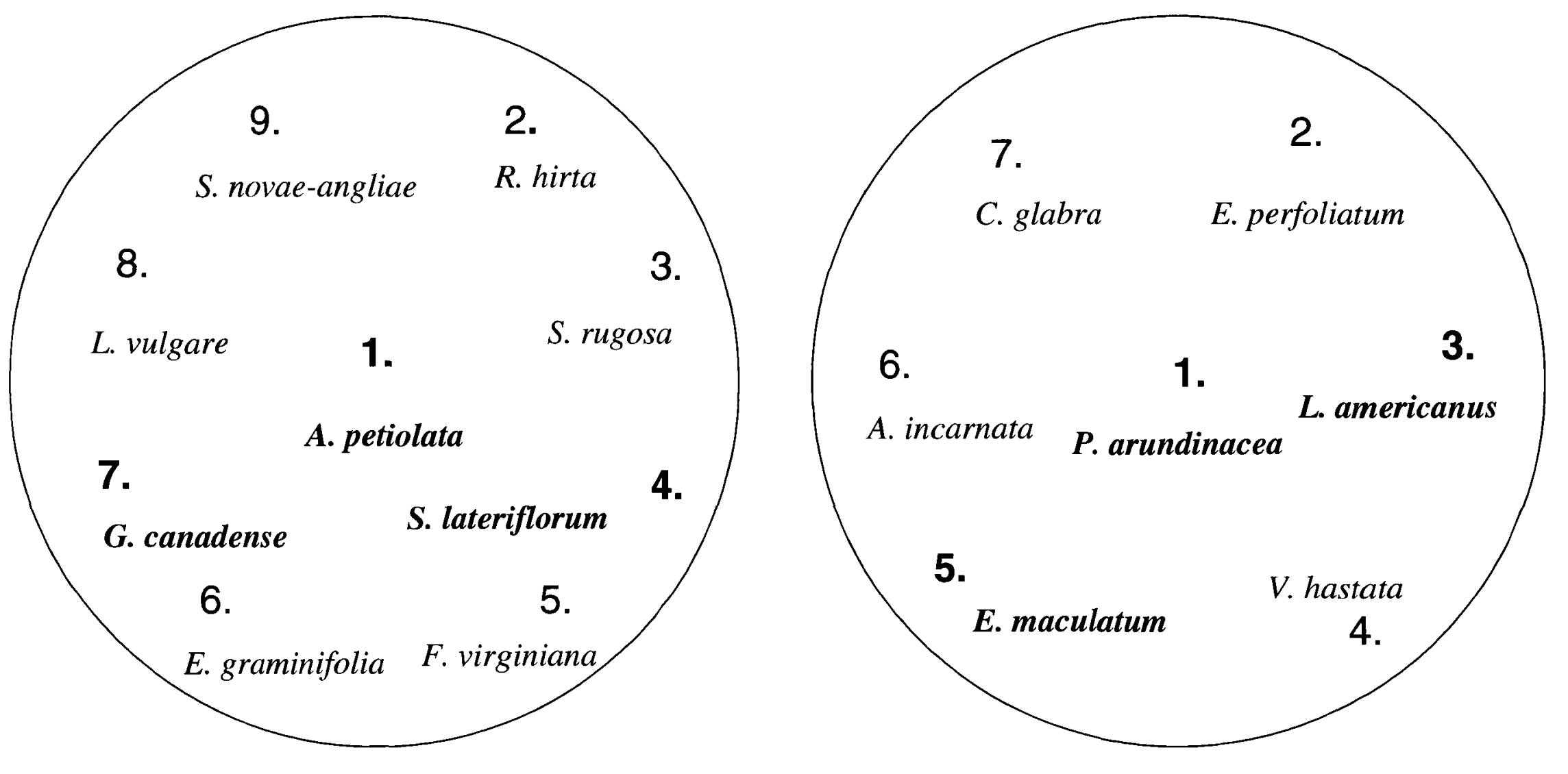
APPENDIX 4. Comparison between outdoor and greenhouse weather conditions. Conditions followed by the same letter are not statistically different, conditions followed by different letters are statistically different.

120
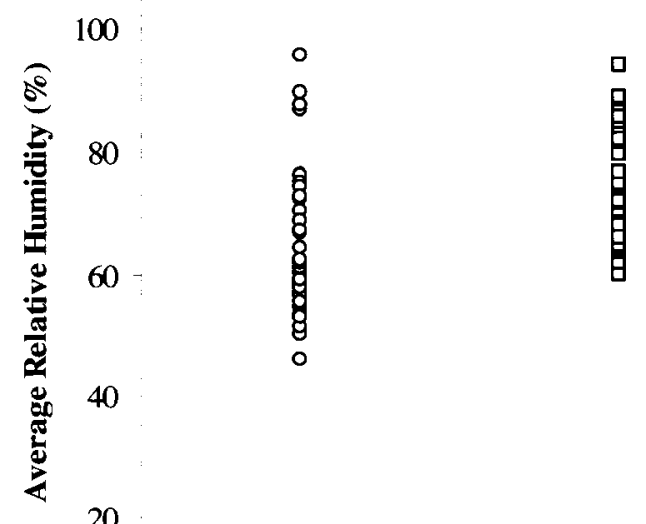

20

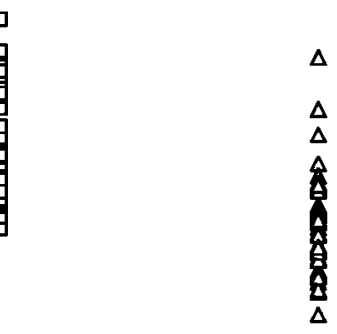

\section{8
8
8
8}

0

$\begin{array}{llll}\text { Gyphosate } & \text { Gyphosate } & \text { Atrazine } & \text { Atrazine } \\ \text { Greenhouse }^{\text {a }} & \text { Outdoor } & \text { Greenhouse }^{\text {a }} & \text { Outdoor }^{\text {b }}\end{array}$

A4.1. Average daily relative humidity (\%) for greenhouse and outdoor terrestrial microcosms treated with glyphosate and atrazine

2500
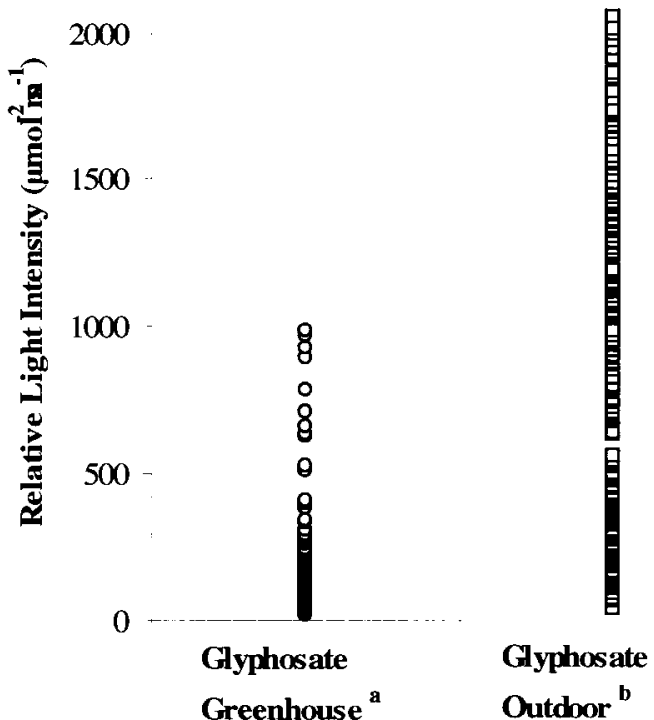

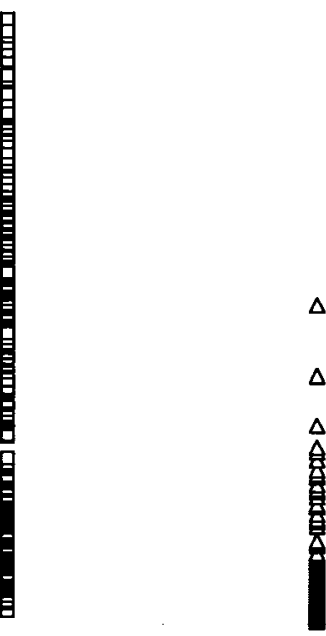

Atrazine

Greenhouse $^{\text {a }}$

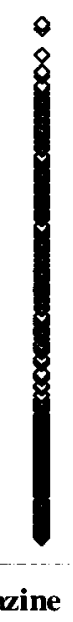

Outdoor ${ }^{\text {b }}$

A4.2. Relative light intensity $\left(\mu \mathrm{mol} \mathrm{m} \mathrm{m}^{-2} \mathrm{~s}^{-1}\right.$ ) taken during stomatal conductance measurements for three greenhouse and outdoor terrestrial microcosm target species $7,14,21$ and 28 days after exposure to glyphosate or atrazine. 
35

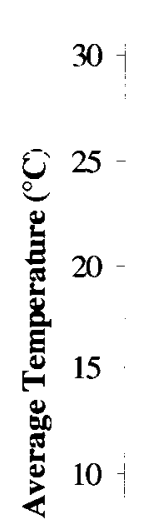

8
8
8
8
8
8

5
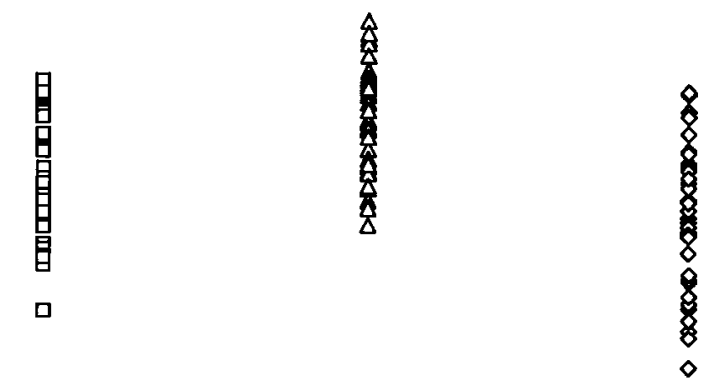

$\begin{array}{ll}\text { Glyphosate } & \text { Glyphosate } \\ \text { Greenhouse }^{\text {a }} & \text { Outdoor }^{b}\end{array}$

Atrazine

Atrazine

Greenhouse $^{\text {a }}$

Outdoor $^{c}$

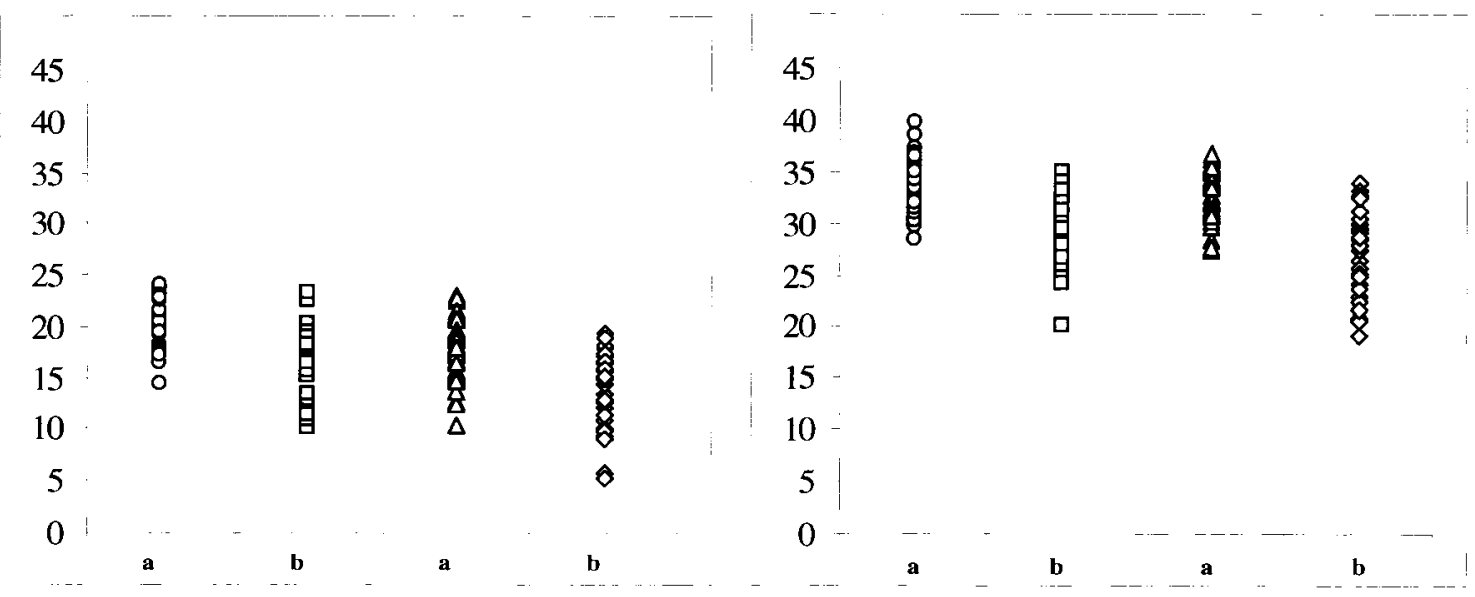

A4.3. Average, minimum and maximum daily temperatures $\left({ }^{\circ} \mathrm{C}\right)$ for greenhouse and outdoor terrestrial microcosms treated with glyphosate and atrazine. 